\title{
Investigação dos mecanismos de nucleação de trincas de fadiga térmica em um aço ferramenta com carbonetos de nióbio
}

Tese apresentada à Escola Politécnica da Universidade de São Paulo para obtenção do Título de Doutora em Ciências. 



\section{Investigação dos mecanismos de nucleação de trincas de fadiga térmica em um aço ferramenta com carbonetos de nióbio}

Tese apresentada à Escola Politécnica da Universidade de São Paulo para obtenção do Título de Doutora em Ciências.

Área de concentração:

Engenharia Metalúrgica e de Materiais

Orientador:

Prof. Dr. André Paulo Tschiptschin 
Este exemplar foi revisado e corrigido em relação à versão original, sob responsabilidade única do autor e com a anuência de seu orientador.

São Paulo, de de

Assinatura do autor:

Assinatura do orientador:

\section{Catalogação-na-publicação}

Braga, Ana Paola Villalva

Investigação dos mecanismos de nucleação de trincas de fadiga térmica em um aço ferramenta com carbonetos de nióbio / A. P. V. Braga -- versão corr. - São Paulo, 2017.

$$
220 \mathrm{p}
$$

Tese (Doutorado) - Escola Politécnica da Universidade de São Paulo. Departamento de Engenharia Metalúrgica e de Materiais.

1.Fadiga térmica 2.Aço ferramenta 3.Carboneto de nióbio 4.Oxidação 5.Nucleação de trinca I.Universidade de São Paulo. Escola Politécnica. Departamento de Engenharia Metalúrgica e de Materiais II.t. 


\section{Dedicatória}

Àqueles que batalham por igualdade e justiça na ciência, na religião, na política e na sociedade. 



\section{Agradecimentos}

Ao meu orientador Prof. Dr. André Paulo Tschiptschin, pela confiança e oportunidade de trabalhar ao seu lado neste projeto.

Ao Dr. Mario Boccalini Jr., por tamanho empenho no meu desenvolvimento pessoal e profissional, sempre me incentivando e ajudando a incrementar meu trabalho.

Aos colegas do grupo de Processos Termomecânicos do Laboratório de Processos Metalúrgicos do IPT, pelo suporte durante todas as fases críticas do Projeto Danos, que nos levou a outro patamar técnico e científico. Sandra, Alexandre, Felipe, Bruna, Diogo e Jayson, vocês foram grandiosos parceiros.

Aos parceiros do Laboratório de Fenômenos de Superfície do PME-Poli, principalmente ao Luiz Lima , pelo apoio no modelamento do ensaio de fadiga térmica e ajuda com a discussão dos resultados.

À Gerdau, com Claudia Serantoni e Mario Vitor Leite, pela relação de confiança e parceria firmada há anos, que continue rendendo desenvolvimentos de excelência.

Ao BNDES pelo apoio financeiro no programa Funtec.

À minha família: meu marido Rafael, minha mãe Malu, meu pai Edson, minha irmã Marcela e todos que sempre torcem por mim e me ajudam a conciliar a vida profissional com a pessoal. Meus filhos, Sônia e Ivan, vocês me dão motivação pra caminhar!

À minha família postiça, do Templo Escola Tríade, aos guardiões da esquerda e da direita, à minha mãe lansã e meu pai Oxalá.

Sem vocês, isso tudo nem faz sentido.

Gratidão! $\odot$ 
Refletiu a luz divina Com todo seu esplendor.

É do reino de Oxalá Onde há paz e amor Luz que refletiu na terra, Luz que refletiu no mar, Luz que veio de Aruanda para tudo iluminar.

A Umbanda é paz e amor É um mundo cheio de luz É a força que nos dá vida E à grandeza nos conduz. Avante, filhos de fé!

Com a nossa lei não há! Levando ao mundo inteiro a bandeira de Oxalá. Levando ao mundo inteiro a bandeira de Oxalá! (Hino da Umbanda)

É preciso amar as pessoas como se não houvesse amanhã. Porque, se você parar pra pensar, na verdade, não há. - Dado Villa-Lobos e Renato Russo 


\section{Resumo}

Foram realizados ensaios de fadiga térmica em um aço ferramenta com carbonetos de nióbio, aplicando-se exclusivamente tensões térmicas aos corpos de prova, a partir do controle da temperatura a cada ciclo térmico e da atmosfera a que o corpo de prova foi exposto. O objetivo deste trabalho foi investigar e entender os mecanismos de nucleação de trincas de fadiga térmica e da formação da malha de trincas na superfície em corpos de prova submetidos a ciclos térmicos semelhantes aos sofridos por ferramentas de conformação a quente. Para isso, olhou-se em maiores detalhes para as características da superfície durante os primeiros estágios da formação das trincas e para a microestrutura próxima à superfície. Foram realizados ensaios de oxidação estática, medição do campo de temperaturas, cálculo de tensões por modelamento com elementos finitos e ensaios de fadiga térmica com variação de quatro condições de ensaio: temperatura máxima, velocidade de aquecimento, dureza do material e atmosfera. O dano após os ensaios de fadiga térmica foi avaliado a cada 1000 ciclos em microscópio óptico para medição da densidade de trincas secundárias (de relevância secundária, mas que geralmente surgem primeiro). Após a falha, os corpos de prova foram analisados em seção transversal e por tomografia de raios- $X$, para caracterização das trincas primárias (de maior relevância). Ao final do trabalho, conclui-se que 0 estudo de fadiga térmica deve sempre estar associado ao estudo da oxidação do material, para simular as condições de operação normal de ferramentas. Os mecanismos de surgimento de uma malha de trincas secundária, restrita à camada de óxido, e uma malha de trincas primária, que leva o material à falha, são distintos porém relacionados. A formação de malha secundária acelera a nucleação de trincas primárias pelo surgimento de pontos de concentração de tensão e de oxidação preferencial. Os carbonetos de nióbio têm papel importante na nucleação de trincas primárias e secundárias, pela formação de interface e pela concentração de tensões. Todos os parâmetros variados nos ensaios tiveram impacto relevante na evolução do dano de fadiga térmica, sendo que alguns causam efeito na malha secundária e outros influenciam a malha primária e o tempo de vida dos corpos de prova.

Palavras chave: Fadiga térmica. Aço ferramenta. Carboneto de nióbio. Oxidação. Nucleação de trinca. 



\section{Abstract}

Thermal fatigue tests were carried out in a tool steel with niobium carbides, applying only thermal stresses to the test specimens, by temperature and atmosphere control on each thermal cycle to which the specimen was exposed. The aim of this work was to investigate and understand the nucleation mechanisms of thermal fatigue and the formation of the crack network on the surface in specimens subjected to thermal cycles similar to those suffered by hot forming tools. For this, we looked in greater detail for the surface characteristics during the early stages of cracking and for the microstructure close to the surface. Static oxidation tests, measurement of the temperature fields, stress calculation by finite element modeling and thermal fatigue tests with four test conditions were performed: maximum temperature, heating rate, material hardness and atmosphere. The damage after the thermal fatigue tests was evaluated every 1000 cycles under optical microscope to measure the secondary crack density (of secondary relevance, which usually arise first). After the failure, the specimens were analyzed in cross-section and by X-ray tomography, to characterize the primary cracks (of major relevance). At the end, it is concluded that the study of thermal fatigue must always be associated to the study of the oxidation of the material, to simulate the normal operating conditions of tools. The mechanisms for the appearance of a secondary crack network, restricted to the oxide layer, and a primary crack network, which leads the material to failure, are distinct but related. Secondary network formation accelerates the nucleation of primary cracks by the appearance of preferential stress concentration and oxidation sites. The niobium carbides play an important role in the nucleation of primary and secondary cracks, by formation of interfaces and concentration of stresses. All parameters varied in the tests had a relevant impact on the evolution of the thermal fatigue damage, some of which have an effect on the secondary network and others influence the primary network and the lifetime of the specimens.

Keywords: Thermal fatigue. Tool steel. Niobium carbide. Oxidation. Crack nucleation. 



\section{Lista de Figuras}

2.1 Microestrutura da liga Nb2,5Ti no estado bruto de fundição mostrando a distribuição dos carbonetos. . . . . . . . . . . . . . . . . 33

2.2 Seção transversal do corpo de prova da liga Nb2,5Ti ensaiada sob fadiga térmica por Silva. . . . . . . . . . . . . . . . . . 34

2.3 Modos de falha em matrizes de forjamento e asregiões de maior probabilidade de ocorrência . . . . . . . . . . . . . . . . 37

2.4 Aparência microscópica de diferentes defeitos por corrosão . . . 38

2.5 Curva típica de carregamento cíclico em ensaio de fadiga . . . . 40

2.6 Restrições internas causando tensão superficial compressiva durante aquecimento rápido . . . . . . . . . . . . . . . . . . . . 42

2.7 Curva de carregamento em ensaio de fadiga com tensão média negativa ..................... . . 43

2.8 Representação de um volume de controle diferencial para análise de transmissão de calor em coordenadas cilíndricas . . . . . 44

2.9 Superfície dos cilindros de laminação de materiais H13 e C99 com danos de fadiga térmica . . . . . . . . . . . . . . . 48

2.10 Danos no cilindro de C99, em seção transversal . . . . . . . . . 49

2.11 Malha de trincas de fadiga térmica observada em um pistão industrial. . . . . . . . . . . . . . . . . 50 50

2.12 Três tipos de teste de fadiga, de acordo com o tipo de carregamento. . . . . . . . . . . . . . . . . . . . 51

2.13 Corpo de prova para ensaio de fadiga utilizado por Bergstrom et al. . . . . . . . . . . . . . . . . . 5 53

2.14 Fotografia do corpo de prova para ensaio de fadiga térmica utilizado por Brandim et al. . . . . . . . . . . . . . . . . . 55

2.15 Equipamento de fadiga térmica usado por Brandim et al. . . . . 56

2.16 Arranjo experimental utilizado por Caliskanoglu et al. . . . . . . . 58 
2.17 Corpo de prova para ensaio de fadiga térmica utilizado por Medjedoub e Rézaï-Aria. . . . . . . . . . . . . . . . . . . . . . . . 59

2.18 Instrumentação do corpo de prova para aquisição de dados de temperatura utilizada por Medjedoub. . . . . . . . . . . . 60

2.19 Corpos de prova para ensaio de fadiga térmica utilizados por Serantoni. . . . . . . . . . . . . . . . . . . . . 62

2.20 Representação esquemática do ciclo térmico aplicado ao corpo de prova utilizado por Serantoni durante o ensaio de fadiga térmica. . . . . . . . . . . . . . . . . . . . . . . 62

2.21 Corpos de prova para ensaio de fadiga térmica utilizados por Matsumoto. . . . . . . . . . . . . . . . . . . . . . . 65

2.22 Corpos de prova para ensaio de fadiga térmica utilizados por Tang et al.

2.23 Aparato experimental para fadiga térmica em leito fluidizado utilizado por Howes.

2.24 Equipamento para avaliação dos efeitos de fadiga térmica, corrosão por alumínio e erosão das amostras de aço H13 estudadas por Froehlich.

2.25 Dimensões do corpo de prova para ensaio de fadiga térmica utilizado por Ott e Diehl e Ferreira. . . . . . . . . . . . . . . . . 71

2.26 Aparato experimental desenvolvido por Ott e Diehl e utilizado por Ferreira. . . . . . . . . . . . . . . . . . . . . . . . . . 71

3.1 Curva de revenimento $\ldots \ldots \ldots \ldots$. . . . . . . . . . . .

3.2 Microestrutura da liga C99 após tratamento térmico $\ldots \ldots$. . . 79

3.3 Tarugos fundidos para produção de corpos de prova de fadiga térmica . . . . . . . . . . . . . . . . . 80

3.4 Desenho do corpo de prova de fadiga térmica . . . . . . . . . 81

3.5 Desenho do corpo de prova com furos para ensaio de fadiga térmica instrumentado . . . . . . . . . . . . . . . . . 82

3.6 Etapas de preparação por FIB da superfície e seção transversal das amostras oxidadas para medição da camada de óxido $\ldots 84$

3.7 Montagem experimental para ensaio de fadiga térmica . . . . . . 85 
3.8 Painel de controle para ensaio de fadiga térmica $\ldots \ldots$. . . 85

3.9 Três versões de bobina de indução utilizadas nos ensaios . . . . 86

3.10 Distribuição de temperaturas no corpo de prova provocadas pela bobina, calculados por simulação . . . . . . . . . . . . . . . 87

3.11 Evolução da densidade de trincas microscópicas como função do número de ciclos de fadiga térmica, por Rézaï-Aria. Efeito da temperatura máxima. . . . . . . . . . . . . . . . . 88

3.12 Padrão de aquecimento indutivo produzido em uma barra redonda posicionada fora do centro em uma bobina de indução redonda . . . . . . . . . . . . . . . . . . . 90

3.13 Marcação de uma fotografia de microscópio óptico para medição de trincas . . . . . . . . . . . . . . . . . . . . . . . 91

3.14 Esquema de criação do Minimum Bounding Rectangle sobre a detecção de uma trinca . . . . . . . . . . . . . . . . . . 91

3.15 Tela de trabalho do software utilizado para medição da densidade de trincas. . . . . . . . . . . . . . . . . . . . . . 92

3.16 Medidas de densidade de trincas secundárias em corpos de prova ensaiados em diferentes temperaturas, para seleção da temperatura dos ensaios de referência . . . . . . . . . . . 98

3.17 Condições de ensaio de fadiga térmica para avaliação dos parâmetros . . . . . . . . . . . . . . . . . . . . . . . . 100

4.1 Observação do aumento da espessura da camada de óxidos formados após aquecimento por 120 minutos em diferentes temperaturas . . . . . . . . . . . . . . . . . 103

4.2 Oxidação da superfície de amostras aquecidas até $600^{\circ} \mathrm{C}$, por diferentes períodos (30 a $240 \mathrm{~min}$ ), sem ataque. . . . . . . . . 104

4.3 Oxidação da superfície de amostras aquecidas até $600^{\circ} \mathrm{C}$, por diferentes períodos (30 a $240 \mathrm{~min}$ ), com ataque. . . . . . . . . 105

4.4 Pontos de oxidação preferencial em contornos de grão e carbonetos observados nas amostras oxidadas a $600{ }^{\circ} \mathrm{C} \ldots \ldots 106$

4.5 Análises de composição química por EDS na camada de óxido de amostras oxidadas a $600^{\circ} \mathrm{C} \ldots$. . . . . . . . . . . 107 
4.6 Análises de composição química por EDS na camada de óxido formada sobre os carbonetos de nióbio oxidados a $600{ }^{\circ} \mathrm{C} \ldots 107$

4.7 Regiões de formação de camada de óxidos sobre a matriz de aço e os carbonetos de nióbio . . . . . . . . . . . . . . 108

4.8 Curvas da evolução da espessura da camada de óxido em função do tmepo de aquecimento. . . . . . . . . . . . . . . . . . 109

4.9 Perfil de temperaturas na direção transversal em 1 ciclo térmico, nas condições REF, REV e ARG . . . . . . . . . . . . . 112

4.10 Perfil de temperaturas na direção transversal em 1 ciclo térmico, na condição HOT . . . . . . . . . . . . . . . . . . . . . . 112

4.11 Perfil de temperaturas na direção transversal em 1 ciclo térmico, na condição LOW . . . . . . . . . . . . . . . . . . . 113

4.12 Mapas de contorno de temperatura em função do tempo e da distância à superfície do corpo de prova . . . . . . . . . . . . 117

4.13 Curvas de tensão na superfície calculadas durante os 3 primeiros ciclos de fadiga térmica nas condições REF, HOT e LOW (histerese) . . . . . . . . . . . . . . . . . . . . 118

4.14 Representação das curvas de tensão-deformação durante um ciclo de carregamento com efeito Bauschinger . . . . . . . . 118

4.15 Distribuição de tensões no corpo de prova aquecido na condição REF, calculadas por MEF . . . . . . . . . . . . . . . . 120

4.16 Distribuição de tensões no corpo de prova aquecido na condição HOT, calculadas por MEF . . . . . . . . . . . . . . . . . . . 121

4.17 Distribuição de tensões no corpo de prova aquecido na condição LOW, calculadas por MEF . . . . . . . . . . . . . . . 122

4.18 Evolução da densidade de trincas em um corpo de prova ensaiado até $550^{\circ} \mathrm{C}$, com velocidade alta de aquecimento, até 15000 ciclos

4.19 Evolução da densidade de trincas em um corpo de prova ensaiado até $550^{\circ} \mathrm{C}$, com velocidade alta de aquecimento, até 15000 ciclos

4.20 Trincas primárias (macrotrincas) formadas durante ensaios de fadiga térmica, causando vazamento de água e perda de massa 126 
4.21 Imagens (MEV) da superfície do corpo de prova após ensaio de fadiga térmica . . . . . . . . . . . . . . . . . . . 127

4.22 Imagens (MEV) da região de canto entre superfície e seção transversal polida do corpo de prova após ensaio de 5000 na condição REF . . . . . . . . . . . . . . . . . . . . . . . . 127

4.23 Pontos de oxidação preferencial formados durante ensaio de fadiga térmica, em diferentes estágios . . . . . . . . . . . 128

4.24 Pontos de oxidação preferencial formados durante ensaio de fadiga térmica, após ataque com Nital . . . . . . . . . . . . 129

4.25 Formação de trincas de fadiga térmica no material X38CrMoV5-3130

4.26 Evolução do dano superficial do corpo de prova REF1 após os primeiros 1000 ciclos . . . . . . . . . . . . . . . . . . . . . . . 132

4.27 Evolução do dano superficial do corpo de prova REF2 . . . . . . 133

4.28 Evolução do dano superficial do corpo de prova REF3 . . . . . . 134

4.29 Medidas de densidade de trincas nos corpos de prova ensaiados na condição REF . . . . . . . . . . . . . . . . . . . . 135

4.30 Superfície dos corpos de prova ensaiados na condição HOT . 137

4.31 Medidas de densidade de trincas secundárias nas amostras ensaiadas na condição HOT . . . . . . . . . . . . . . . . . . . . . 138

4.32 Morfologia da camada de óxido no início da formação . . . . . . 139

4.33 Evolução do dano superficial do corpo de prova LOW1 . . . . . . 140

4.34 Evolução do dano superficial do corpo de prova LOW2 . . . . . . 141

4.35 Evolução do dano superficial do corpo de prova LOW3 . . . . . . 142

4.36 Medidas de densidade de trincas secundárias nas amostras ensaiadas na condição LOW . . . . . . . . . . . . . . . . . . . 143

4.37 Evolução do dano superficial do corpo de prova REV1 . . . . . . 145

4.38 Superfície do corpo de prova REV1 após 6000 ciclos, indicando pontos de perda de material em meio à malha de trincas primárias 146

4.39 Medidas de densidade de trincas secundárias nas amostras ensaiadas na condição REV . . . . . . . . . . . . . . . . . . 147

4.40 Evolução do dano superficial do corpo de prova ARG1 . . . . . . 150 
4.41 Evolução do dano superficial do corpo de prova ARG2 . . . . . 150

4.42 Evolução do dano superficial do corpo de prova ARG3 . . . . . . 151

4.43 Medidas de densidade de trincas secundárias nas amostras ensaiadas na condição ARG . . . . . . . . . . . . . . . 152

4.44 Trinca primária nucleada na parte de trás do corpo de prova ARG1 sobre um defeito de fundição . . . . . . . . . . . . . 153

4.45 Posição típica de afloramento das trincas primárias (macrotrincas) quando ensaiadas nas 5 condições de ensaio . . . . . . . 154

4.46 Caminho de propagação pela superfície de trincas primárias sobre a malha de trincas secundárias . . . . . . . . . . . 155

4.47 Medidas de densidade de trincas secundárias em todas as amostras ensaiadas, comparando os resultados das 5 condições de ensaio . . . . . . . . . . . . . . . . . . 156

4.48 Pontos de nucleação de trincas primárias causadas por defeitos de fundição . . . . . . . . . . . . . . . . . . 158

4.49 Pontos de oxidação preferencial na interface matriz/óxido nos pontos abaixo das trincas secundárias . . . . . . . . . 159

4.50 Trinca primária na amostra LOW1, nucleando na parece interna do furo, propagando até perto da superfície . . . . . . . 160

4.51 Trincas primárias na amostra REV3 $\ldots \ldots \ldots$

4.52 Pontos de oxidação preferencial em interfaces carboneto/matriz e contornos de grão da matriz das amostras ensaiadas . . . . . 161

4.53 Análises de EDS nas camadas de óxido formadas sobre o corpo de prova REF1 . . . . . . . . . . . . . . . 163

4.54 Análises de EDS em uma inclusão de filme de óxido . . . . . . 164

4.55 Camada de óxido formada sobre o corpo de prova ARG2 . . . 165

4.56 Comparação da amostra REF2 após ensaio e a medição por tomografia de raios-X . . . . . . . . . . . . . 167

4.57 Comparação da amostra HOT2 após ensaio e a medição por tomografia de raios-X . . . . . . . . . . . . . 168

4.58 Comparação da amostra LOW2 após ensaio e a medição por tomografia de raios-X . . . . . . . . . . . . . . . 169 
4.59 Comparação da amostra REV1 após ensaio e a medição por tomografia de raios-X . . . . . . . . . . . . 170

4.60 Comparação da amostra ARG1 após ensaio e a medição por tomografia de raios-X . . . . . . . . . . . . . . 171

4.61 Imagens de trincas feitas por tomografia de raios- $X \ldots \ldots$. . . . 172

5.1 Medição de espessura da camada oxidada . . . . . . . . . 176

5.2 Desenho esquemático das formas de propagação de trincas no estágio II sob vácuo e ao ar, propostas por Gell . . . . . . . . . 177

5.3 Exemplo de um material com gradiente de temperaturas e propriedades mecânicas (dureza e tenacidade) . . . . . . . . . . 182 



\section{Lista de Tabelas}

2.1 Composição do aço ferramenta C99. . . . . . . . . . . . . . . . 34

2.2 Propriedades mecânicas e térmicas do aço ferramenta C99 . . . 35

3.1 Resultados das análises químicas das corridas de C99 . . . . . 80

3.2 Resumo dos dados das curvas de ciclos térmicos em 6 condições de ensaio de fadiga térmica. . . . . . . . . . . . . . . . . . 96

3.3 Matriz de experimentos, 5 condições, em triplicata . . . . . . . . 99

4.1 Medidas da camada de óxido sobre as amostras oxidadas em temperaturas e tempos diferentes . . . . . . . . . . . . . . . 109

4.2 Valores de temperatura máxima e mínima, tempo de aquecimento e resfriamento, velocidade de aquecimento e resfriamento e tempo acima de $400^{\circ} \mathrm{C}$, para cada condição de ensaio, por ciclo154

5.1 Quadro resumo das análises de trincas nas condições de ensaio estudadas . . . . . . . . . . . . . . . . . . . . . . . . 183 



\section{Sumário}

1 Introdução $\quad 21$

1.1 O que este trabalho acrescenta? . . . . . . . . . . . . . 24

1.2 Evolução do estudo de fadiga térmica nas ferramentas de conformação . . . . . . . . . . . . . . . . . . . . 25

2 Revisão da Literatura $\quad 27$

2.1 Estado da arte do estudo de fadiga térmica . . . . . . . . . . . . 29

2.2 Aços Ferramenta . . . . . . . . . . . . . . . . . . . 31

2.2.1 Aços para trabalho a quente . . . . . . . . . . . 31

2.2 .2 A liga "C99" . . . . . . . . . . . . . . . . . 32

2.3 Falha em ferramentas de conformação a quente . . . . . . . . 36

2.4 Fadiga - mecânica e térmica . . . . . . . . . . . . 39

2.4.1 Testes de fadiga . . . . . . . . . . . . . . . 39

2.4.2 Sobre a fadiga térmica . . . . . . . . . . . . . . 41

2.5 Métodos de ensaio de fadiga térmica . . . . . . . . . . . . 51

2.5.1 Aspectos gerais . . . . . . . . . . . . . . 51

2.5.2 Configurações de ensaio . . . . . . . . . . . . . 52

3 Materiais e Métodos $\quad 73$

3.1 Plano de trabalho . . . . . . . . . . . . . . . 75

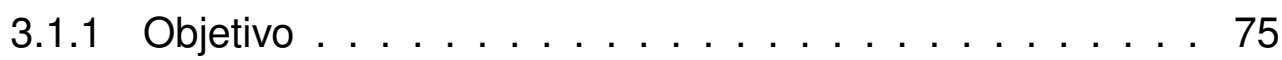

3.1.2 Planejamento . . . . . . . . . . . . . . . 75

3.2 Materiais . . . . . . . . . . . . . . . 78

3.2.1 Seleção do material . . . . . . . . . . . . . . . . . 78

3.2.2 Confecção dos corpos de prova . . . . . . . . . . . . . 79 
3.3 Métodos . . . . . . . . . . . . . . . . . . . . 83

3.3.1 Ensaios de oxidação estática . . . . . . . . . . . . . 83

3.3.2 Equipamento dos ensaios de fadiga térmica . . . . . . . 83

3.3.3 Avaliação do dano . . . . . . . . . . . . . . . . 88

3.3.4 Cálculos de tensões na superfície . . . . . . . . . . 93

3.4 Ensaios preliminares . . . . . . . . . . . . . . . . 95

3.4.1 Tempo, temperatura e regularidade do ensaio . . . . . . 95

3.4.2 Teste de resposta do controlador . . . . . . . . . . . 97

3.4.3 Efeito da pressão de água no aquecimento e resfriamento 97

3.4.4 Seleção da condição de referência . . . . . . . . . . . 97

3.5 Projeto de experimentos . . . . . . . . . . . . . . . 98

4 Resultados 101

4.1 Ensaios de oxidação estática . . . . . . . . . . . . . . 103

4.1 .1 Análise dos óxidos . . . . . . . . . . . . . . . . 105

4.1 .2 Medição de espessura . . . . . . . . . . . . . . 108

4.2 Cálculo de tensões . . . . . . . . . . . . . . . . 111

4.2.1 Modelamento por Elementos Finitos . . . . . . . . . . 115

4.3 Fadiga térmica . . . . . . . . . . . . . . . . . . 123

4.3.1 Observações preliminares da morfologia das malhas de trincas térmicas . . . . . . . . . . . . . . . . 124

4.3.2 Ensaios de fadiga térmica . . . . . . . . . . . . . . 131

4.3.3 Caracterização da seção transversal . . . . . . . . . . . 157

4.3.4 Tomografia de raios- $X \ldots \ldots \ldots 6$

5 Discussão 173

5.1 Oxidação . . . . . . . . . . . . . . . . . . . 175

5.2 Pontos de nucleação de trincas: Condições de heterogeneidade 178

5.3 Relações entre trincas e o carregamento . . . . . . . . . . 179 
$5.3 .1 \quad \Delta T_{C} \ldots \ldots \ldots \ldots \ldots \ldots \ldots \ldots \ldots \ldots \ldots$

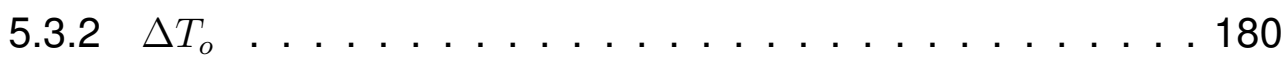

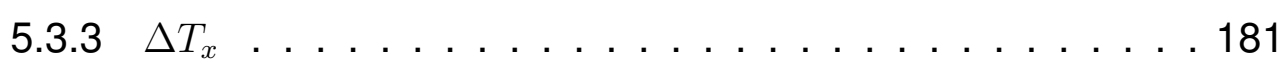

5.4 Propriedades mecânicas . . . . . . . . . . . . . . . 182

5.5 Resumo das condições de ensaio . . . . . . . . . . . 183

$5.5 .1 \quad$ REF . . . . . . . . . . . . . . . . 183

5.5 .2 НОт . . . . . . . . . . . . . . . . . . . 184

5.5 .3 LOW . . . . . . . . . . . . . . . . . . . . . 184

5.5 .4 REV . . . . . . . . . . . . . . . . . . . . . . 184

$5.5 .5 \quad$ ARG . . . . . . . . . . . . . . . 185

6 Conclusões 187

$\begin{array}{ll}\text { Referências } & 191\end{array}$

Apêndice A - Imagens de tomografia 197

A.1 Corpo de prova REF2 - Vista rotacional: $0-180^{\circ} \ldots \ldots$. . . 199

A.2 Corpo de prova REF2 - Vista direita: 1 - $30 \mathrm{~mm}$. . . . . . . 201

A.3 Corpo de prova REF2 - Vista de topo: 1 - $77 \mathrm{~mm}$. . . . . . . . 203

A.4 Corpo de prova HOT2 - Vista de topo: 1 - $77 \mathrm{~mm}$. . . . . . . . 205

A.5 Corpo de prova HOT2 - Vista rotacional: $0-180^{\circ} \ldots$. . . . 207

A.6 Corpo de prova LOW2 - Vista rotacional: $0-180^{\circ} \ldots . .209$

A.7 Corpo de prova LOW2 - Vista direita: 1 - $30 \mathrm{~mm}$. . . . . . . 211

A.8 Corpo de prova LOW2 - Vista de topo: 1 - $70 \mathrm{~mm}$. . . . . . 213

A.9 Corpo de prova REV1 - Vista rotacional: $0-180^{\circ} \ldots$. . . . 215

A.10 Corpo de prova ARG1 - Vista de topo: 1 - $78 \mathrm{~mm}$. . . . . . 217

A.11 Corpo de prova ARG1 - Vista rotacional: $0-180^{\circ} \ldots \ldots 219$ 

1 Introdução 

O entendimento e o estudo do fenômeno e dos mecanismos de fadiga térmica têm sido feitos de maneira que pode ser considerada ainda superficial. Como muitas áreas da ciência, principalmente na Metalurgia, que lida com a prática à frente da ciência em vários de seus aspectos, o estudo da falha de componentes metálicos por fadiga iniciou-se como um diagnóstico de falha, em meados de $1829^{[1]}$, e foi paulatinamente se aprofundando no entendimento das causas e de seus mecanismos até atingir um ponto onde é possível fazer algumas previsões sobre sua ocorrência.

É claro que, por causa do número muito maior de ocorrências e (geralmente) maior impacto em caso de falha, a fadiga mecânica tem destaque entre os pesquisadores de fadiga. Fadiga térmica é definida por alguns autores como um modo de fadiga por aplicação cíclica de tensões de origem térmica, devido a contrações e dilatações térmicas do material ${ }^{[2-4]}$. Componentes sujeitos a fadiga térmica são, na maior parte, componentes de motores a combustão ou ferramentas da indústria de conformação mecânica a quente.

Nos estudos já realizados sobre fadiga térmica, o material objeto de estudo é quase sempre um aço homogêneo ${ }^{1}$. De fato, muitos aços utilizados em componentes sujeitos à fadiga térmica são homogêneos, como o H11 (para injeção sob pressão) e o H13 (forjamento e extrusão) ou aços para pistões a diesel, mas há também ferramentas multifásicas, como os cilindros de laminação feitos de ferro fundido, por exemplo.

Quanto à metodologia de ensaio, não faltaram esforço e inovação nas tentativas de reproduzir, controlar e registrar o fenômeno. Entretanto, os métodos de caracterização limitam-se, até hoje, à mensuração de alterações na superfície dos corpos de prova ou a ensaios destrutivos para caracterização da malha de trincas na seção transversal - assim como os ensaios de fadiga mecânica tradicionais.

Visto isso, justifica-se a inovação deste trabalho, que estudará a fadiga térmica de um aço heterogêneo, buscando explicar os mecanismos de nucleação das trincas superficiais em variadas condições de aquecimento e microestutura que ocorrem tanto em aços homogêneos como heterogêneos.

Ao longo das últimas três décadas, o Instituto de Pesquisas Tecnológicas do Estado de São Paulo - IPT - e a Escola Politécnica da Universidade de São Paulo - EPUSP - desenvolveram atividades sistemáticas na área de Materi-

\footnotetext{
${ }^{1}$ Considerando-se como homogêneos os aços isentos de partículas maiores que $1 \mu \mathrm{m}$ e que partículas submicrométricas dispersas na matriz não afetam a homogeneidade da microestrutura.
} 
ais Metálicos Resistentes ao Desgaste. Grande parte delas é caracterizada por forte envolvimento com o meio externo, principalmente empresas do setor metalomecânico - com destaque para a Gerdau (antiga Villares), na área de cilindros de laminação - e universidades nos níveis nacional e internacional.

O projeto IPT entitulado "Sistema avançado para projeto de ligas aplicadas em ferramentas de conformação a quente" - onde se insere este trabalho de doutorado - tem como objetivo desenvolver um sistema baseado em modelamento computacional para auxiliar no projeto de ligas metálicas de alto desempenho destinadas a ferramentas de conformação a quente, tendo como base a simulação do dano progressivo das ferramentas durante o serviço e da relação desse dano com a microestrutura da liga, substituindo o tradicional procedimento de "tentativa e erro" com ganhos de custo, desempenho e reprodutibilidade para fabricantes e usuários destas ferramentas na indústria metalúrgica de transformação. O modelamento e parte dos ensaios laboratoriais foram realizados por uma equipe do Laboratório de Fenômenos de Superfície do Departamento de Engenharia Mecânica da Escola Politécnica da Universidade de São Paulo (LFS - PME - EPUSP). Os ensaios laboratoriais de fadiga térmica e os ensaios em escala piloto foram realizados pelo IPT.

As ferramentas de conformação utilizadas para modelagem foram cilindro de laminação, matriz de forjamento e molde para fundição sob pressão de alumínio. Após o modelamento inicial, foram feitos experimentos em escala laboratorial e piloto, a fim de validar e realimentar o modelo. Este trabalho de doutorado trata exclusivamente de detalhes do ensaio de fadiga térmica realizado em uma das ligas estudadas.

\subsection{O que este trabalho acrescenta?}

O diferencial deste trabalho é a forma com que as fontes de dados são obtidas e analisadas durante e após os ensaios de fadiga térmica, em um material de microestrutura mais complexa que os tradicionalmente estudados, com o intuito de entender os fenômenos que ocorrem desde o início da formação de trincas de fadiga térmica e em que ordem eles ocorrem.

Os ensaios são conduzidos aplicando-se exclusivamente tensões térmicas aos corpos de prova, a partir do controle da temperatura a cada ciclo térmico e da atmosfera a que o corpo de prova está exposto, que pode ser oxidante ou inerte. 
A microestrutura do material estudado neste trabalho tem matriz de martensita revenida, com carbonetos primários de geometria poligonal e carbonetos secundários dispersos na matriz. Segundo o levantamento bibliográfico que será mostrado adiante, os estudos de fadiga térmica têm sido focados em materiais predominantemente homogêneos (partículas de segunda fase submicrométricas), com matriz de martensita revenida, como o aço ferramenta AISI H11. A introdução de partículas de segunda fase com dimensão de 5-10 $\mu \mathrm{m}$ é significativa e determinante na geração de tensões dentro da microestrutura ${ }^{[5,6]}$.

\subsection{Evolução do estudo de fadiga térmica nas ferramentas de conformação}

Na produção de materiais laminados, qualidade e produtividade estão intimamente ligadas ao desempenho em serviço dos cilindros de laminação. A qualidade do produto laminado é determinada principalmente por sua forma, rugosidade e variação dimensional, que estão diretamente associadas à forma e à rugosidade dos cilindros de trabalho do trem de laminação. A produtividade do trem de laminação, por sua vez, é parcialmente determinada pelo tempo de serviço ininterrupto que o cilindro de trabalho pode suportar, mantendo a qualidade do produto laminado acima do nível estabelecido ${ }^{1}$.

A deterioração dos cilindros de trabalho de trens de laminação de tiras a quente é um processo complexo caracterizado pela ação simultânea de vários modos de desgaste, tais como abrasão, oxidação, adesão e fadiga térmica. Estão envolvidas interações microscópicas e dinâmicas na interface entre o cilindro e o material laminado, sendo praticamente impossível observá-las diretamente. Sabe-se, porém, que há certa prevalência de um ou dois daqueles modos de desgaste em cada cadeira ou conjunto de cadeiras do trem de laminação, dependendo principalmente das temperaturas de trabalho. Desta forma, nas três primeiras cadeiras (temperatura mais elevada), os fenômenos de fadiga térmica e oxidação apresentam-se de forma mais intensa, enquanto nas duas últimas, abrasão e adesão são os fenômenos predominantes. Nas cadeiras intermediárias, por conseguinte, observa-se a ação de todos eles de maneira aproximadamente equitativa.

\footnotetext{
${ }^{1}$ Os cilindros de laminação são periodicamente retirados de serviço para recuperação da sua superfície, que nada mais é do que a remoção, por usinagem, da camada superficial deteriorada pelo próprio uso, e pode ou não envolver etapas de tratamento superficial, como a nitretação.
} 
Devido à falta de métodos aprovados de dimensionamento, o projeto de ferramenta é baseado principalmente na experiência prática de engenheiros de ferramentas e manufatura. A segurança contra falha prematura da ferramenta muitas vezes tem prioridade sobre a eficiência da produção, a fim de evitar adaptações da ferramenta e atrasos durante uma campanha de produção. Muitas ferramentas usadas na indústria não são otimizadas, por exemplo, com respeito à vida de ferramenta ou tempo de ciclo do processo. Métodos confiáveis para dimensionamento de ferramentas de manufatura e estimativa de vida de ferramenta são, portanto, de vital importância para conquistar limitações baseadas no ferramental. ${ }^{[7]}$

Embora algum progresso tenha sido alcançado nos últimos anos na análise de carregamentos e de vida das ferramentas baseados em Método de Elementos Finitos (MEF ou FEM), ainda não há uma metodologia geral com métodos rápidos e eficientes. Tal quadro de métodos deve incluir os seguintes elementos fundamentais: ${ }^{[7]}$

- Simulação do processo de manufatura

- Análise avançada do carregamento da ferramenta

- Previsão da vida da ferramenta

Fadiga, desgaste, ataque químico e perda de dureza são os mecanismos de dano mais relevantes que limitam a vida das ferramentas ${ }^{[7,8]}$. É comum, por razões de simplicidade e prioridades distintas, que os trabalhos de pesquisa sejam concentrados em um dos modos de dano. No caso deste trabalho, o foco será dado na interação e dependência da oxidação e das tensões térmicas na superfície e próximo a ela. O projeto do IPT, entretanto, abraçou o estudo de abrasão, adesão e fadiga térmica, os chamados "eventos unitários", em ensaios e modelos combinando dois ou três eventos, buscando previsão de dano, como perda de massa. 
2 Revisão da Literatura 



\subsection{Estado da arte do estudo de fadiga térmica}

Desde 1987, inicialmente em Chicago, E.U.A., e depois em outros países grandes produtores de aços ferramenta e ferramentas de conformação, um grupo de pesquisadores da área se reúne para apresentar trabalhos relacionados ao estado da arte e tendências futuras no campo de ferramentas e materiais para ferramentas, no International Tool Conference. Foi feito um levantamento nos anais do $5^{\circ}$ (1999) ao $10^{\circ}$ (2016) congressos, buscando por trabalhos relacionados à fadiga térmica das ferramentas. Esse levantamento busca saber quais são as formas de estudo que são feitas sobre o tema (teórico, experimental, modelamento), o método de aplicação de ciclagem térmica utilizado (fundição sob pressão, forjamento ou outros), a escala (micro ou macroscópica) e o tipo de material estudado (homogêneo ou heterogêneo).

Algumas conclusões podem ser tiradas da análise desses anais:

- Mesmo em um congresso especializado em aços ferramenta, ao longo de 18 anos, foram apresentados apenas 21 artigos cujo tema principal era fadiga térmica. ${ }^{[8-28]}$

- O estudo de fadiga térmica está concentrado em poucos e pequenos grupos de pesquisa. Vários nomes de autores se repetem ao longo dos anos.

- Quase todos os trabalhos são experimentais. Poucos são os que se utilizam de estudos teóricos para aprofundar o conhecimento sobre o fenômeno. ${ }^{[12,15,17,23]}$

- O modelamento matemático ainda é utilizado de forma tímida por todos os grupos de pesquisa. ${ }^{[10,14-16,20,28]}$ Deve ser devido ao fato de que o trabalho experimental ainda seja relativamente novo, sem formas já consagradas de análise e comparação de resultados.

- A principal aplicação dos aços ferramenta que motiva estudos de fadiga térmica ainda é a injeção de metais fundidos sob pressão. ${ }^{[9,10,12-24,26]}$

- A avaliação dos danos de fadiga térmica é geralmente feita na escala microscópica, devido ao tamanho das trincas. ${ }^{[8,10-13, ~ 18, ~ 19, ~ 21, ~ 22, ~ 24, ~ 26-28] ~}$ Ainda não há muita clareza de como transpor os resultados em escala micro para a escala macro, nem como relacionar os danos microscópicos com a microestrutura dos materiais. 
- O foco dos estudos de fadiga térmica é quase sempre um aço homogêneo e, na maioria das vezes, é o aço $\mathrm{H} 11$ ou $\mathrm{H} 13$. Entre as raras exceções $^{[8,19,25,27]}$, o primeiro trabalho encontrado nessa conferência que tratava de um aço com carbonetos primários pertence a este mesmo grupo de trabalho, do IPT e EPUSP ${ }^{[8]}$. 


\subsection{Aços Ferramenta}

\subsubsection{Aços para trabalho a quente}

Aços ferramenta são aços usados na fabricação de ferramentas, matrizes e moldes que deformam, moldam ou cortam outros materiais - aços, metais não ferrosos, polímeros, cerâmicas e compósitos. Além dos elementos de liga, os aços ferramenta são considerados especiais porque sua produção demanda a mais alta qualidade em cada etapa do processo, devido à alta exigência de desempenho.

Existem dezenas de normalizações internacionais para aços ferramenta, sendo mais utilizada a classificação American Iron and Steel Institute (AISI). Esses aços têm sido organizados em grupos ou tipos que evoluíram para realizar funções específicas, como forjamento, trabalho a frio, injeção e usinagem em alta velocidade, em várias condições de operação. Dentro de cada grupo ou tipo pode haver muitas classes que são similares porém diferem levemente entre si para acomodar um pouco as diferentes exigências de processo, condições de operação ou materiais trabalhados. ${ }^{[29]}$

As combinações das propriedades dos vários grupos de aços ferramenta são funções do processo de tratamento térmico, determinado pela liga. O tratamento térmico final de aços ferramenta, invariavelmente, consiste em um processo em três fases: aquecimento para a formação de austenita, refrigeração ou têmpera para transformar a austenita em martensita e de aquecimento ou revenimento para eliminar austenita retida e formar carbonetos secundários.

Todos os aços para ferramentas e moldes para aplicações a quente devem ter as seguintes características gerais:

Resistência à deformação nas temperaturas de trabalho. É a característica principal que diferencia os aços ferramenta para trabalho a quente dos demais.

Resistência ao impacto. É necessária para prevenir trincamento ou faIhas catastróficas.

Resistência ao desgaste em alta temperatura. Geralmente, é alcançada através da seleção de elementos de liga e microestruturas que tenham maior dureza a quente, porém tenacidade mais baixa. 
Resistência a distorções durante tratamento térmico. É fundamental, para garantir a forma final do produto conformado, que as matrizes e moldes tenham máxima precisão dimensional.

Usinabilidade. A usinabilidade deve ser melhorada por processos primários e recozimento e não pode envolver formação de inclusões ou outras partículas de segunda fase (utilizadas em outros aços), que diminuem a resistência ao impacto e à fadiga.

Resistência à fadiga térmica. É o principal fator que limita a vida dos aços ferramenta para trabalho a quente usados para conformar materiais com exigência de bom acabamento superficial.

Ainda que os fabricantes de cilindros de laminação tenham desenvolvido ligas projetadas especificamente para as condições operacionais de cada unidade de laminação a quente, suas composições químicas frequentemente se encontram dentro das seguintes faixas: $1,5-3,0 \% \mathrm{C}$; até $6 \% \mathrm{~W}$; até $6 \% \mathrm{Mo}$; 3 $8 \% \mathrm{Cr}$ e $4-10 \% \mathrm{~V}$. A microestrutura bruta de fundição possui matriz com produtos de decomposição da austenita (normalmente martensita ou bainita) e alguma austenita retida, carbonetos secundários globulares precipitados na matriz e carbonetos eutéticos constituindo células eutéticas ou distribuídos em regiões interdendríticas.

\subsubsection{A liga "C99"}

Em seu trabalho de mestrado, Silva ${ }^{1[6]}$ objetivou o estudo da microestrutura de ligas Fe-W-Cr-Mo-V-C-Nb baseadas no conceito "aço matriz + NbC". Foi estudado, em particular, o efeito da variação nos teores de $\mathrm{Nb}, \mathrm{C}$ (na proporção estequiométrica para formação do $\mathrm{NbC}$ ) e da adição de Ti sobre as características dos carbonetos $\mathrm{NbC}$ primários e eutéticos, e os seus comportamentos frente a solicitações de fadiga térmica, desgaste por deslizamento alternado (disco contra esfera) e desgaste abrasivo (roda de borracha), comparando-os com o comportamento sob mesmas solicitações de um aço rápido comercial do tipo Fe-W-Cr-Mo-V-C com alto teor de vanádio.

O titânio atuou como modificador da morfologia dos carbonetos de nióbio, que assumem morfologia poligonal ao invés da forma de cruz de malta

\footnotetext{
${ }^{1} \mathrm{O}$ trabalho de Silva ${ }^{[6]}$ foi realizado durante estágio no IPT - Instituto de Pesquisas Tecnológicas do Estado de São Paulo.
} 
e escrita chinesa. A fração volumétrica de carbonetos também foi estudada variando-se estequiometricamente os teores de $\mathrm{Nb}$ e $\mathrm{C}$.

O comportamento sob fadiga térmica foi avaliado por meio de ensaio de fadiga térmica em "disco chanfrado", conduzido em condições semelhantes com algumas melhorias - ao ensaio elaborado por Serantoni ${ }^{[5]}$. Os corpos de prova foram aquecidos por $10 \mathrm{~s}$ e resfriados por imersão em água à temperatura ambiente, e sua caracterização buscou quantificar as trincas em ensaios destrutivos. As ligas com carbonetos $\mathrm{NbC}$ com morfologia poligonal e menor fração volumétrica de carbonetos apresentaram o melhor desempenho (menos propagação) sob fadiga térmica devido à baixa razão entre continuidade e distância livre média entre carbonetos.

A liga com melhor desempenho combinado de resistência ao desgaste e fadiga térmica foi a liga Nb2,5Ti (0,83\%C-2,0\%W-3,0\%Mo-4,6\%Cr-1,0\%V$2,5 \% \mathrm{Nb}-0,1 \% \mathrm{Ti}$ ) (Figura 2.1). Na seção transversal, observada no microscópio eletrônico de varredura (Figura 2.2), observou-se que a propagação das trincas dá-se preferencialmente pela interface carboneto/matriz $(A)$ e na região sub-superficial foi verificada a presença de carbonetos $\mathrm{NbC}$ poligonais fraturados $(B)$, o que também pode ser comprovado neste trabalho. Esta liga também teve o melhor desempenho (menor desgaste) nos ensaios de abrasão com roda de borracha.

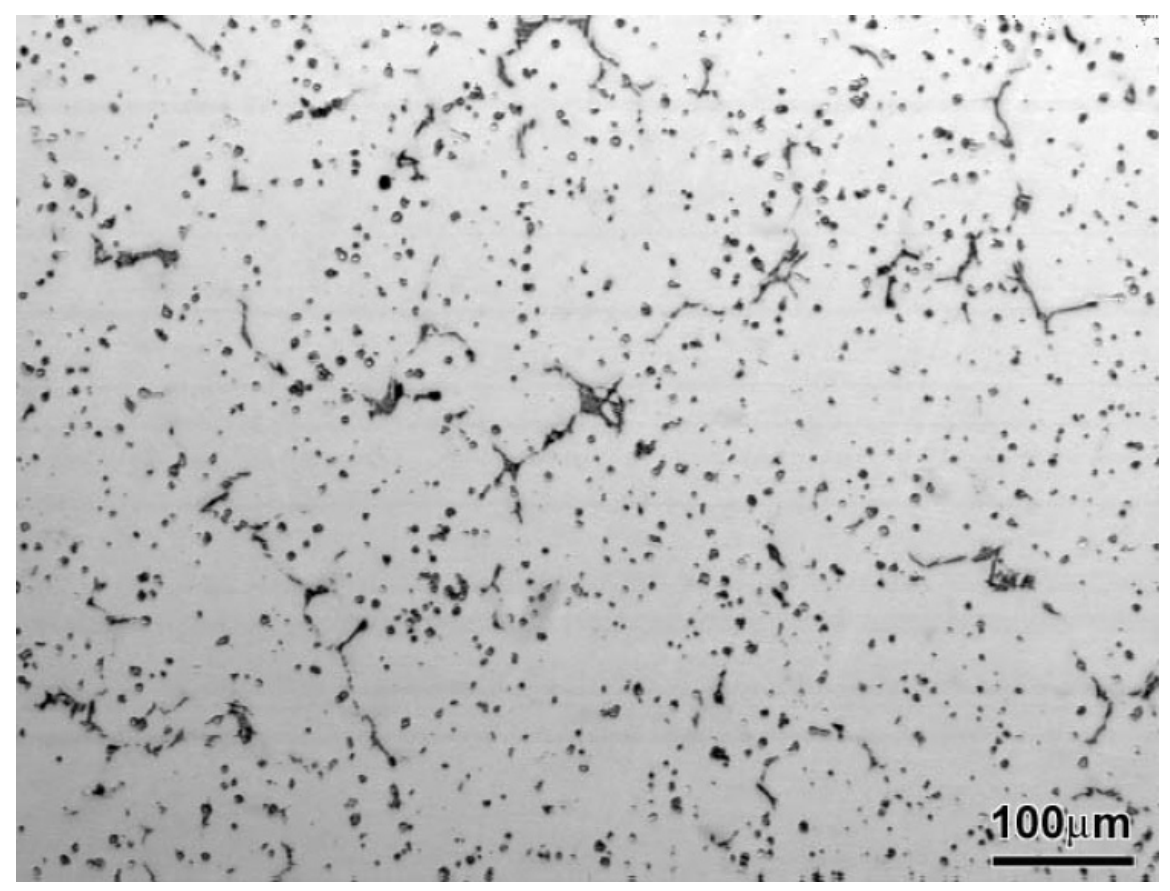

Figura 2.1: Microestrutura da liga Nb2,5Ti no estado bruto de fundição mostrando a distribuição dos carbonetos. Ataque: Murakami. ${ }^{[6]}$

Desde o seu desenvolvimento, foram sendo realizadas pequenas altera- 


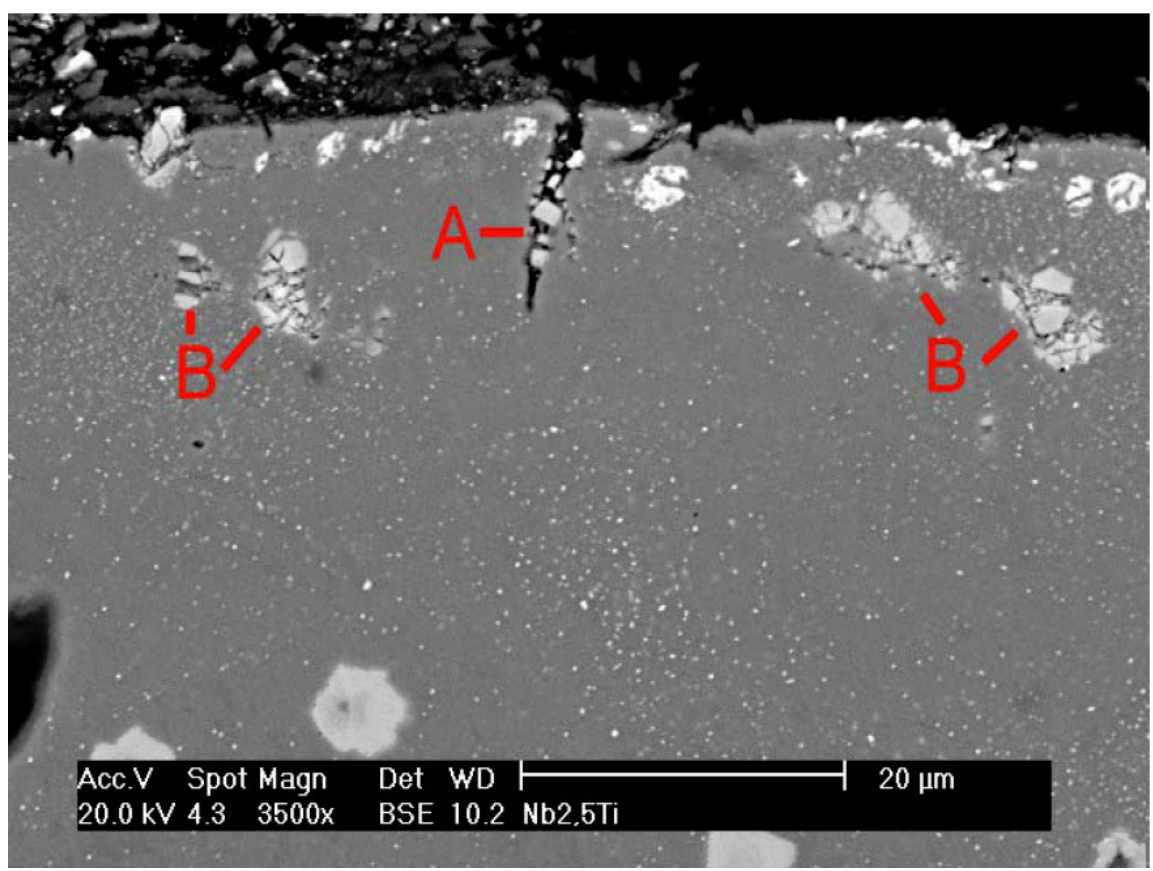

Figura 2.2: Seção transversal do corpo de prova da liga Nb2,5Ti ensaiada sob fadiga térmica por Silva ${ }^{[6]}$. A: propagação de trincas pela interface carboneto/matriz. B: carbonetos NbC poligonais fraturados abaixo da superfície.

ções na liga $\mathrm{Nb2,5Ti} \mathrm{e} \mathrm{no} \mathrm{seu} \mathrm{processo} \mathrm{de} \mathrm{fundição,} \mathrm{de} \mathrm{modo} \mathrm{a} \mathrm{buscar} \mathrm{a}$ melhor configuração de tamanho e distribuição de carbonetos primários $\mathrm{NbC}$. Uma das modificações foi o aumento dos teores de $\mathrm{Nb}$ e $\mathrm{C}$, em proporção estequiométrica, para o teor de 3,5\% Nb. É costume no IPT numerarem-se as "corridas", a fim de identificar adequadamente os materiais produzidos e ter rastreabilidade dos corpos de prova. Assim, elegeu-se a composição da "Corrida 99" como ideal para a otimização das propriedades mecânicas e resistência ao desgaste da liga Nb2,5Ti. A esta última configuração, deu-se o nome de C99. Este trabalho utilizará o termo C99 para designar esta liga, daqui por diante.

A Tabela 2.1 mostra a composição química do aço C99 e a Tabela 2.2 mostra as propriedades mecânicas medidas por ensaios de tração e nanoindentação ${ }^{[30]}$ e propriedades térmicas encontradas na literatura ${ }^{[31,32]}$ ou medidas em ensaio de difusividade térmica ${ }^{[30]}$.

Tabela 2.1: Composição do aço ferramenta C99.

\begin{tabular}{l|ccccccccc}
\hline Elemento & $\mathrm{C}$ & $\mathrm{Cr}$ & $\mathrm{Mn}$ & $\mathrm{Mo}$ & $\mathrm{Nb}$ & $\mathrm{Ti}$ & $\mathrm{Si}$ & $\mathrm{V}$ & $\mathrm{W}$ \\
\hline \multirow{3}{*}{ Composição (wt\%) } & 0,90 & 2,69 & 0,39 & 1,40 & 3,40 & 0,20 & 0,39 & 1,00 & 1,20 \\
& 0,92 & 2,70 & 0,50 & 1,41 & 3,50 & 0,21 & 0,42 & 1,01 & 1,21 \\
\hline
\end{tabular}


Tabela 2.2: Propriedades mecânicas ${ }^{[30]}$ e térmicas ${ }^{[31,32]}$ do aço ferramenta c99.

\begin{tabular}{|c|c|c|c|c|}
\hline & \multirow{2}{*}{ Propriedades } & \multicolumn{3}{|c|}{ Material } \\
\hline & & C99 & Matriz & $\mathrm{NbC}$ \\
\hline 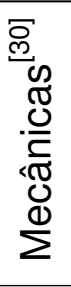 & $\begin{array}{l}\mathrm{E}, 25^{\circ} \mathrm{C}(\mathrm{GPa}) \\
\mathrm{E}, 500^{\circ} \mathrm{C}(\mathrm{GPa}) \\
\sigma_{y}, 25^{\circ} \mathrm{C}(\mathrm{GPa}) \\
\sigma_{y}, 500^{\circ} \mathrm{C}(\mathrm{GPa})\end{array}$ & & $\begin{array}{c}216,7 \\
183,7 \\
1412,6 \\
1102,0\end{array}$ & $\begin{array}{l}341,2 \\
313,9\end{array}$ \\
\hline 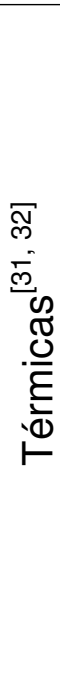 & $\begin{array}{l}\alpha, 25^{\circ} \mathrm{C}\left(\mu m \cdot m^{-1} \cdot K^{-1}\right) \\
\alpha, 450-500^{\circ} \mathrm{C}\left(\mu m \cdot m^{-1} \cdot K^{-1}\right) \\
c, 25^{\circ} \mathrm{C}\left(J \cdot k g^{-1} \cdot K^{-1}\right) \\
c, 450-500^{\circ} \mathrm{C}\left(J \cdot k g^{-1} \cdot K^{-1}\right) \\
\kappa, 25^{\circ} \mathrm{C}\left(W \cdot m^{-1} \cdot K^{-1}\right) \\
\kappa, 450-500^{\circ} \mathrm{C}\left(W \cdot m^{-1} \cdot K^{-1}\right) \\
k, 25^{\circ} \mathrm{C}\left(10^{-6} m^{2} \cdot s^{-1}\right) \\
k, 450-500^{\circ} \mathrm{C}\left(10^{-6} m^{2} \cdot s^{-1}\right) \\
\rho, 25^{\circ} \mathrm{C}\left(k g \cdot m^{-3}\right) \\
\rho, 450-500^{\circ} \mathrm{C}\left(k g \cdot m^{-3}\right)\end{array}$ & $20,2^{[30]}$ & $\begin{array}{c}18,3 \\
450,0 \\
466,0 \\
20,30 \\
23,30 \\
5,78 \\
6,42 \\
7800 \\
7785\end{array}$ & $\begin{array}{r}14,20 \\
7,30\end{array}$ \\
\hline \multicolumn{5}{|c|}{$E=$ Módulo de elasticidade ou de Young } \\
\hline \multicolumn{5}{|c|}{$\sigma_{y}=$ Tensão limite de escoamento } \\
\hline \multicolumn{5}{|c|}{$\alpha=$ Coeficiente de expansão térmica } \\
\hline \multicolumn{5}{|c|}{$c=$ Calor específico } \\
\hline \multicolumn{5}{|c|}{$\kappa=$ Condutividade térmica } \\
\hline \multicolumn{5}{|c|}{$k=$ Difusividade térmica } \\
\hline \multicolumn{5}{|c|}{$\rho=$ Densidade } \\
\hline
\end{tabular}




\subsection{Falha em ferramentas de conformação a quente}

Durante a operação, as ferramentas como matrizes de forjamento, cilindros de laminação e moldes de injeção de alumínio são expostas a uma combinação de múltiplos modos de impacto ${ }^{[3]}$. Os aços ferramenta, especialmente os utilizados nas ferramentas para conformação a quente, inevitavelmente, falharão em algum momento pelo modo de dano que se desenvolver mais rápido. ${ }^{[34]}$ Um dos parâmetros essenciais de uma ferramenta ou um componente é a sua vida em serviço, que descreve o número de componentes produzidos com a ferramenta antes da sua falha. A vida em serviço pode ser melhorada pelo uso de materiais que exibam boa estabilidade térmica e alta tenacidade mesmo em altas temperaturas ${ }^{[26]}$. A falha ocorrerá de maneira mais lenta, ou mais rápida, dependendo de diversos fatores que se definem desde o projeto de manufatura e finalmente pelas condições de operação. ${ }^{[34]}$

De acordo com alguns autores, como Stahlberg and Hallstrom ${ }^{[35]}$ e Biglari ${ }^{[36]}$, mais de $70 \%$ das trocas prematuras de matrizes de forjamento são causadas por desgaste abrasivo. Outros $25 \%$ são devido a fadiga mecânica e apenas $5 \%$ são devidos a deformação plástica e fadiga termomecânica. No forjamento a quente, as partículas abrasivas (principalmente carepa), são a principal causa de abrasão, que é desenvolvida pelo atrito entre a superfície da matriz e a peça forjada, porém cada região do perfil da matriz pode desenvolver preponderância por um dos modos de falha (Figura 2.3), devido ao ciclo térmico e aos esforços a que está submetido. ${ }^{[37]}$

A vida do molde de injeção é determinada pelo tempo de produção, em ritmo normal de trabalho em ciclagem térmica, produzindo peças com ausência de defeitos, sejam eles superficiais, dimensionais, internos ou estruturais, como rebarbas, sobras de material etc. Em $80 \%$ dos moldes, a falha é causada pela fadiga térmica, seguida pelas trincas causadas por esforços mecânicos $(9 \%)$, corrosão (7\%) e washout/soldagem (4\%). ${ }^{[6]}$

No processo de desgaste dos cilindros de trabalho de trens de laminação, atuam simultaneamente os danos de abrasão, oxidação, adesão e fadiga térmica, de forma micro e macroscópica. Sabe-se que há certa prevalência de um ou dois daqueles modos de desgaste em cada cadeira ou conjunto de cadeiras do trem de laminação, dependendo principalmente da temperatura de laminação. Desta forma, nas três primeiras cadeiras (temperatura mais elevada) os fenômenos de fadiga térmica e oxidação apresentam-se de forma 


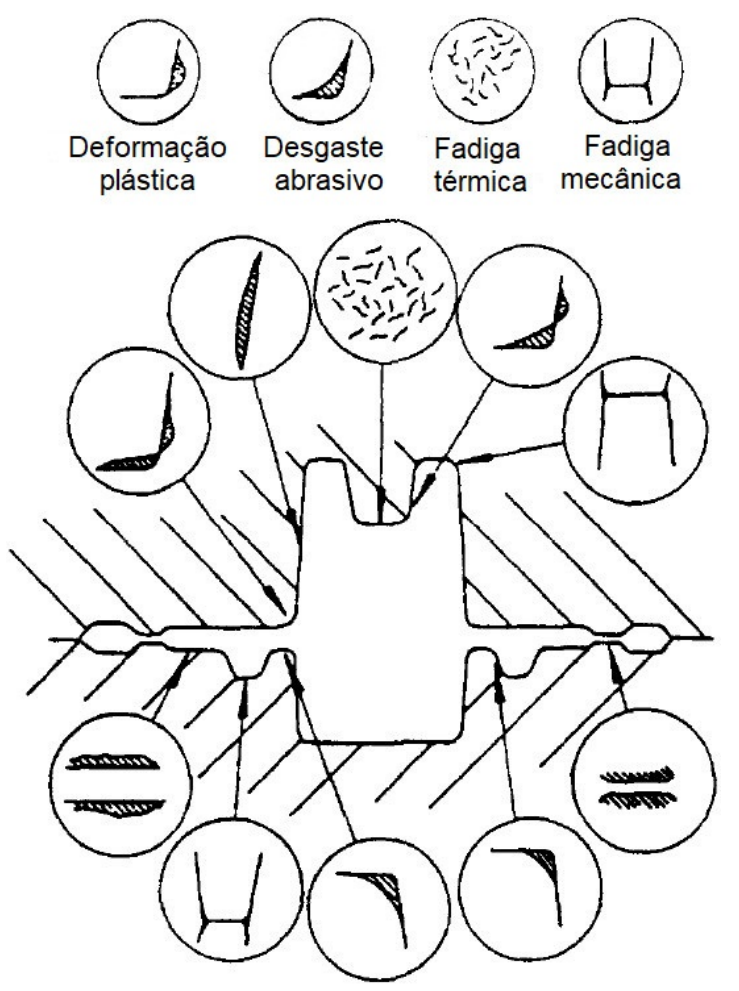

Figura 2.3: Modos de falha em matrizes de forjamento e asregiões de maior probabilidade de ocorrência. ${ }^{[37]}$ Os raios e cantos são regiões mais susceptíveis a deformação plástica ou fadiga mecânica, dependendo da sua forma em relação à movimentação de material. As faces planas horizontais são região de pouca movimentação de material, onde pode ocorrer fadiga térmica. Nas faces onde há intensa movimentação de material, há desgaste abrasivo.

mais intensa, enquanto nas duas últimas, abrasão e adesão são os fenômenos predominantes. Nas cadeiras intermediárias, por conseguinte, observa-se a ação de todos eles de maneira aproximadamente equitativa. ${ }^{[5,38]}$

Para reduzir os efeitos causados pelas altas temperaturas (dilatação térmica, oxidação e alterações de propriedades mecânicas) envolvidas no processo de conformação a quente, as ferramentas são refrigeradas por meio de jatos d'água imediatamente após o fim do contato com o material conformado. Desta forma, a superfície das ferramentas de trabalho é submetida a ciclos térmicos, enquanto a região interna das ferramentas permanece a uma temperatura constante. Conforme relatado por Lima ${ }^{[39]}$, foram conduzidos ensaios de laminação piloto instrumentados que mediram temperaturas na superfície dos cilindros de aproximadamente $450^{\circ} \mathrm{C}$ durante o primeiro passe, laminando tiras a $1200^{\circ} \mathrm{C}$, com uma redução de $2,85 \mathrm{~mm}$ a $28 \mathrm{rpm}$, enquanto a temperatura a $3,4 \mathrm{~mm}$ de profundidade era de no máximo $80^{\circ} \mathrm{C}$.

Schruff ${ }^{[40]}$ chamou a atenção para um modo de falha importante em moldes para fundição sob pressão que frequentemente é negligenciado: a cor- 
rosão causada pela água nos canais de refrigeração, que pode não apenas reduzir a funcionalidade da ferramenta, como pode ser a causa de uma explosão durante o contato com metal líquido. Por análise visual, é possível diagnosticar 3 modos de corrosão em canais (Figura 2.4): corrosão generalizada; corrosão localizada semelhante a corrosão por pitting; e trincas induzidas por corrosão.

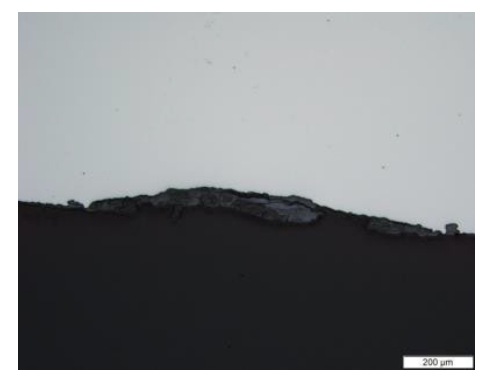

(a)

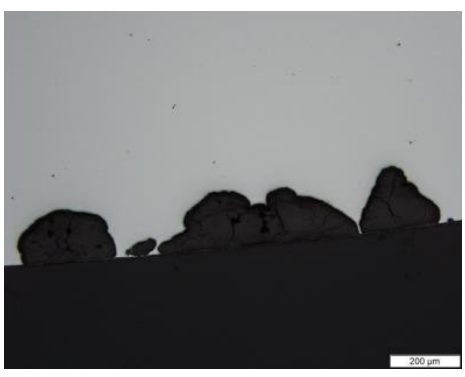

(b)

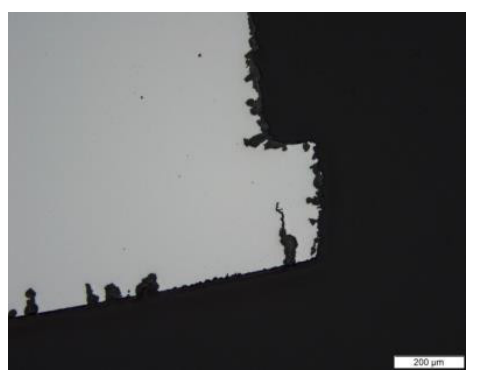

(c)

Figura 2.4: Aparência microscópica de diferentes defeitos por corrosão. (a) Corrosão generalizada; (b) Corrosão localizada; (c) Trincas induzidas por corrosão. ${ }^{[40]}$ 


\subsection{Fadiga - mecânica e térmica}

A definição comumente aceita para fadiga é o fenômeno complexo causado pelo aumento de dano progressivo e cumulativo ao material, que se forma em sucessivos ciclos de carregamento. Essas falhas ocorrem, tipicamente, em níveis de tensão significativamente inferiores aos valores de resistência ao escoamento dos materiais. O número de ciclos de carregamento encontrado em um elemento em serviço pode ser tão alto como $10^{8}$. Assim, a utilização única das teorias de falha estática pode levar a projetos sem segurança quando as solicitações são dinâmicas. ${ }^{[41,42]}$

O processo de falha por fadiga pode ser dividido nos seguintes estágios sucessivos:

- Formação de um núcleo de microtrinca

- Propagação (crescimento) da trinca de fadiga

- Ruptura final

Estes estágios são, cada um, objeto de estudos ainda em desenvolvimento e são apoiados em análises experimentais e teóricas. Estas análises são, em resumo, descritas a seguir.

\subsubsection{Testes de fadiga}

O teste de fadiga consiste basicamente na aplicação cíclica de um carregamento sobre um corpo de prova de geometria definida, a fim de avaliar o efeito do carregamento e do número de ciclos sobre a vida do material.

A Figura 2.5 mostra uma curva típica de carregamento completamente reverso a que pode estar submetido um componente em serviço ou em um ensaio de fadiga. Em geral, as curvas têm aproximadamente a forma senoidal ${ }^{[43]}$.

A partir da Figura 2.5, que mostra uma curva típica de carregamento cíclico em ensaio de fadiga, podem-se identificar e definir os seguintes termos: ${ }^{[41,43,44]}$

$\sigma_{\max }$ - Tensão máxima é a tensão de maior valor, em módulo.

$\sigma_{m i n}$ - Tensão mínima é a tensão de menor valor, em módulo. Em um ciclo completamente reverso, como no caso da Figura 2.5, $\sigma_{\min }=-\sigma_{\max }$. 
$\sigma_{m}$ - Tensão média é a média aritmética entre as tensões máxima e mínima do ciclo. Em um ciclo completamente reverso, $\sigma_{m}=0$.

$\sigma_{a}$ - Amplitude de tensões é a diferença entre a tensão máxima e a tensão mínima, dividida por $2\left(\left(\sigma_{\max }-\sigma_{\min }\right) / 2\right)$. Em um ciclo completamente reverso, $\left|\sigma_{a}\right|=\left|\sigma_{\max }\right|=\left|\sigma_{\min }\right|$.

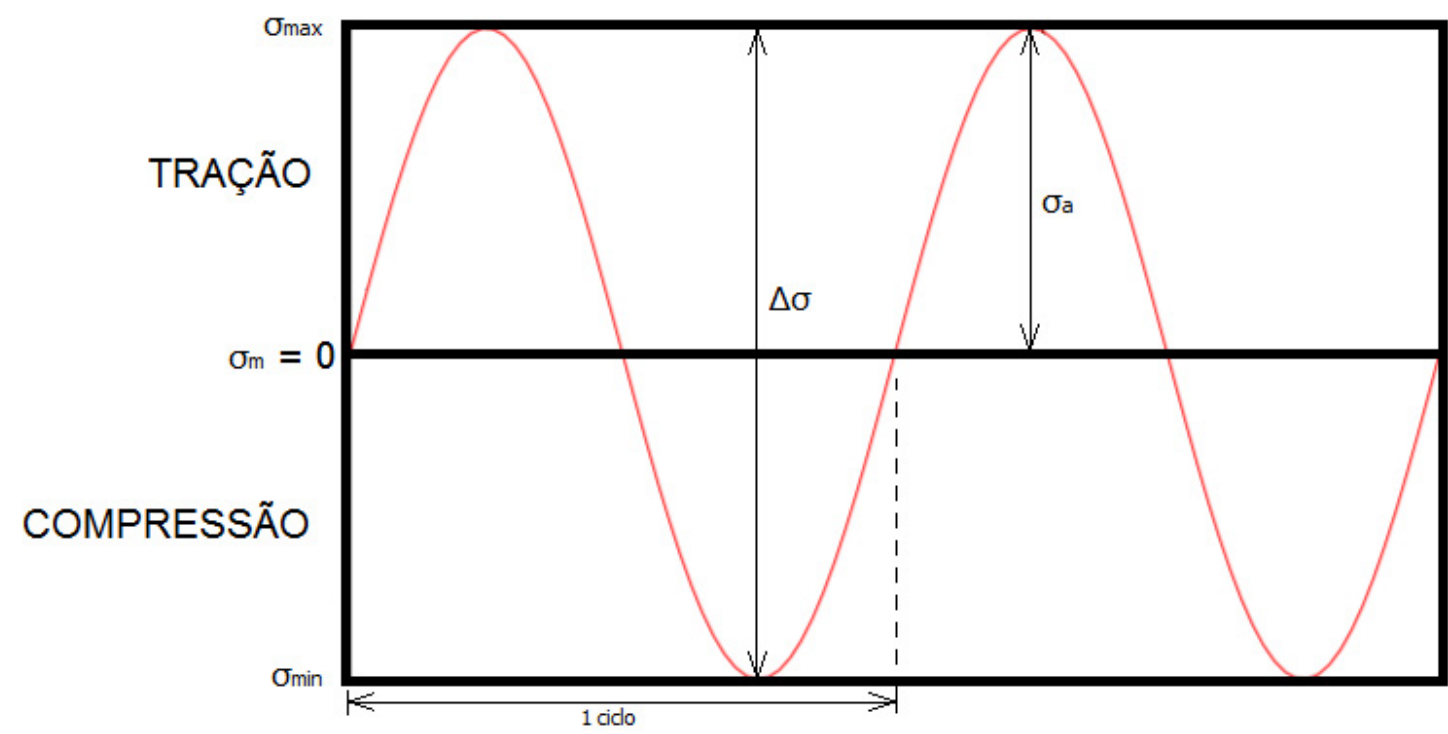

Figura 2.5: Curva típica de carregamento cíclico em ensaio de fadiga, com forma senoidal. A partir da curva, podem-se identificar e definir os termos:

$\sigma_{\max }$ (Tensão máxima); $\sigma_{\min }$ (Tensão mínima); $\sigma_{m}$ (Tensão média); e $\sigma_{a}$ (Amplitude de tensões).

Além disso, podem-se definir:

R - Razão de tensões é a razão entre as tensões máxima e mínima do ciclo $\left(R=\sigma_{\max } / \sigma_{\min }\right)$.

$N_{f}$ - Vida em fadiga é o número de ciclos de tensão que causa falha sob determinadas condições de carregamento. ${ }^{1}$

$N$ - Número de ciclos sofrido até determinado estágio do teste de fadiga.

$C$ - Razão de ciclos é a razão entre o número de ciclos sofrido sob uma determinada tensão e a vida em fadiga média àquele carregamento $\left(C=N / N_{f}\right)$

$\sigma_{N}$ - Tensão de fadiga é o valor de tensão (determinado estatisticamente) para o qual a vida em fadiga é $N_{f}$ ciclos. $\sigma_{N}$ pode ser expresso em termos da amplitude de tensões ou da tensão máxima.

${ }^{1} \mathrm{O}$ critério de falha é definido antes do ensaio e pode ser um certo tamanho de trinca, uma densidade de trincas ou a falha catastrófica. 
$\sigma_{D}$ - Limite de fadiga é o valor da tensão aplicada abaixo da qual um material pode suportar um número infinito de ciclos de carregamento.

Razão de fadiga é a razão entre o limite de fadiga ou da tensão de fadiga e o limite de resistência do material $\left(\sigma_{N} / \sigma_{R}\right.$ ou $\left.\sigma_{D} / \sigma_{R}\right)$.

Frequentemente, em serviço, as solicitações mecânicas sobre um componente não são tensões alternadas, mas uma composição de tensões de tração e/ou de compressão, com um valor de tensão média diferente de zero. Pesquisadores, procurando um entendimento básico do processo de crescimento de trinca de fadiga, têm muitas vezes simplificado as complexidades de microestrutura e carregamento, a fim de reduzir o número de variáveis independentes. A simplificação mais comum é limitar as variações de carregamento a ciclagens com amplitude constante. Outra simplificação importante é feita estudando-se trincas de tamanhos conhecidos e de geometrias bem definidas, mantendo a complexidade da microestrutura. ${ }^{[45]}$

\subsubsection{Sobre a fadiga térmica}

Fadiga térmica é um processo de origem e crescimento de dano em partes de equipamentos e componentes devido a mudanças na energia interna causadas por múltiplas mudanças de temperatura. Brandim et al. definem fadiga térmica como "um processo de aplicação repetitiva de ciclos térmicos, durante o qual tensões e deformações são resultantes exclusivamente da imposição de gradientes de temperatura sem a aplicação de cargas mecânicas". ${ }^{[2]}$

Basicamente, a fadiga térmica é produzida em conjunto pelas mudanças cíclicas ou periódicas de temperatura e por uma restrição completa ou parcial da deformação térmica. A restrição pode ser devida a fatores externos ou internos. As restrições externas produzem forças que agem sobre um componente que é alternadamente aquecido e resfriado, enquanto as restrições internas podem resultar de gradientes de temperatura, anisotropia estrutural ou de diferentes coeficientes de expansão em grãos ou fases adjacentes. ${ }^{[46]}$

Quando o aquecimento rápido (em relação à taxa de transferência de calor) causa expansão térmica da superfície, o restante do componente, por estar a temperatura mais baixa, restringe a deformação da superfície, o que gera tensões compressivas superficiais (Figura 2.6). Tais tensões podem ser suficientes para gerar deformação plástica na região comprimida, especialmente em concentradores de tensões na superfície, como partículas de segunda 
fase. Durante o resfriamento da superfície, da mesma forma, a região interna restinge o seu movimento, podendo gerar tensões de tração após deformação plástica a quente ${ }^{[47]}$. A forma da curva de carregamento, neste caso, é semelhante à mostrada na Figura 2.7. A tensão média do ciclo na superfície é negativa (compressão).

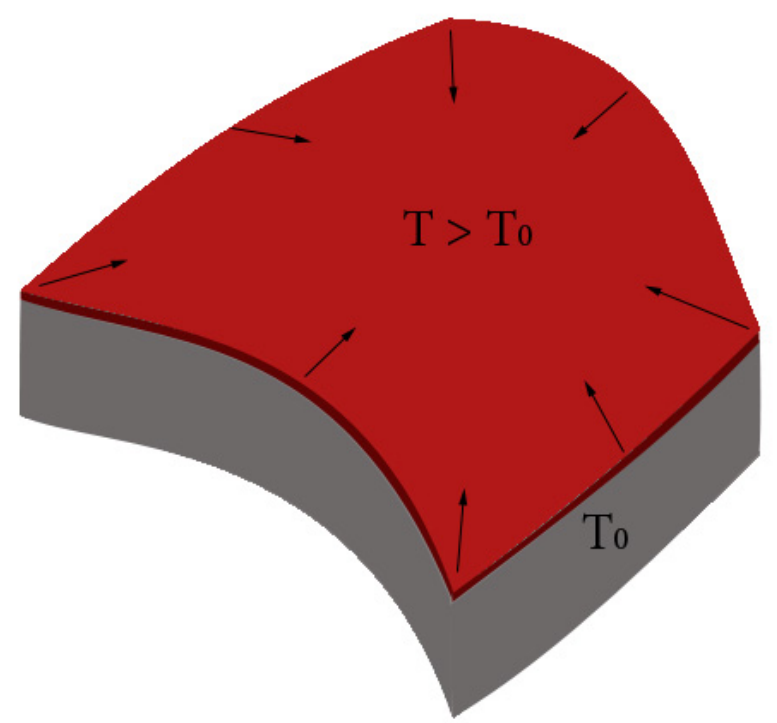

Figura 2.6: Restrições internas causando tensão superficial compressiva durante aquecimento rápido. A superfície do material à temperatura $T_{0}$ passa rapidamente à temperatura $T>T_{0}$, tendendo a dilatar. A região fria age como restritor ao movimento de expansão, aplicando compressão sobre a superfície.

As falhas por fadiga térmica podem ser encontradas em discos de freio, paIhetas de turbina, pistões e cabeçotes de cilindros em motores por combustão interna, cilindros para conformação a quente de aço, matrizes de forjamento, rodas ferroviárias, componentes de fornos e moldes usados para moldagem de vidro ou metal. Como as indústrias buscam sempre aumento de produtividade e os cálculos de projeto de ferramenta auxiliados por simulação computacional são cada vez mais precisos e presentes para evitar falhas mecânicas, a fadiga térmica pode se tornar o modo de falha dominante nos componentes, visto que a temperatura de operação e os gradientes térmicos se tornam mais severos e a vida útil esperada aumenta. ${ }^{[48]}$

A forma da malha de trincas térmicas é dependente do estado de tensões local que, por sua vez, é dependente da geometria do componente e do campo de temperaturas no aquecimento e no resfriamento aplicado sobre a sua superfície. Considerando-se que a fonte de tensões sobre a superfície seja uni- 


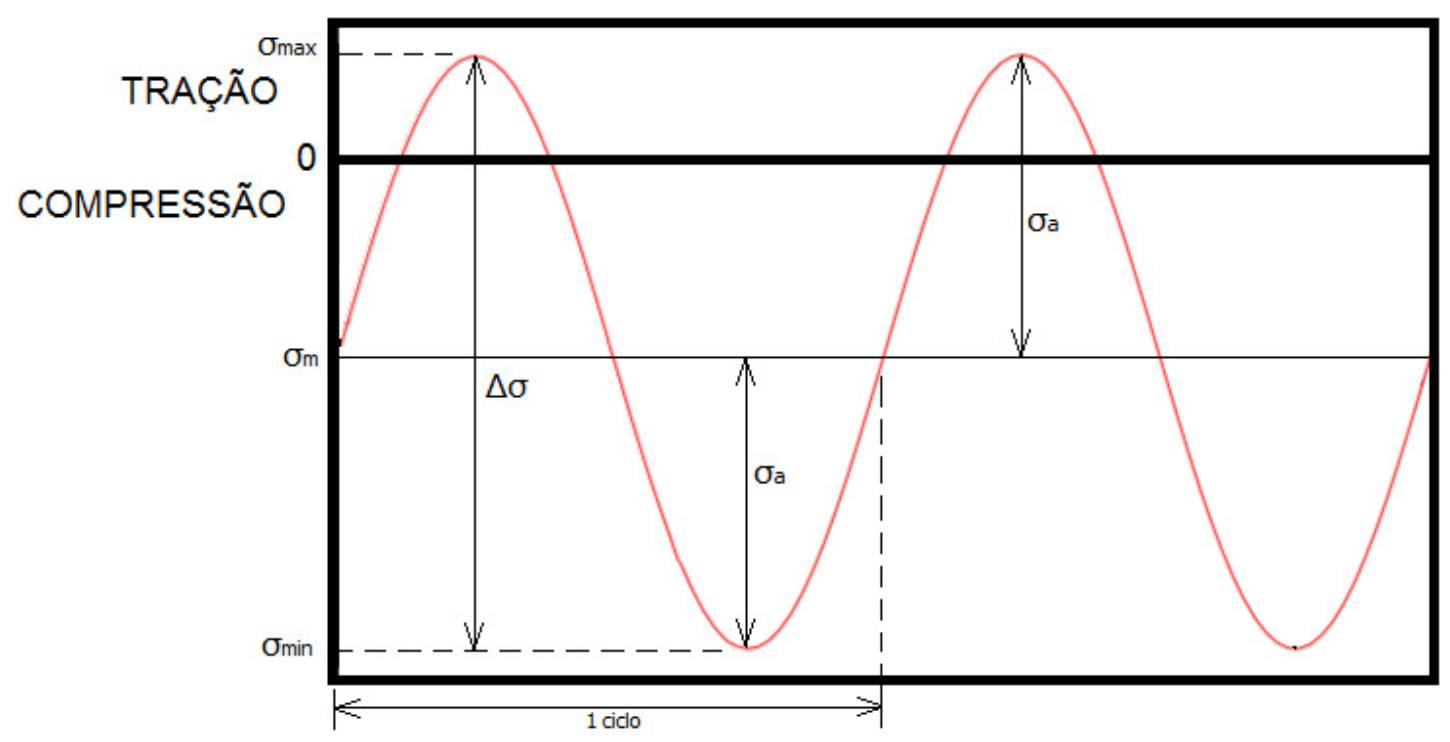

Figura 2.7: Curva de carregamento em ensaio de fadiga com tensão média negativa. A tensão mínima, em módulo, é maior que a tensão máxima, fazendo com que a tensão média seja negativa. O material está, na maior parte do ciclo de carregamento, sofrendo tensões de compressão.

camente térmica e supondo que o campo de temperaturas seja homogêneo em uma região de um componente cilíndrico (Figura 2.8), as componentes de tensão nas direções $(r, \theta, z)$ são proporcionais ao gradiente térmico nas direções correspondentes. Como, sobre a região de temperatura homogênea, a temperatura supostamente não varia nas direções axial $\left(T_{z z}\right)$ e circunferencial $\left(T_{\theta \theta}\right)$, isso implica em tensões iguais nessas direções e na geração de uma malha de trincas "celular", quadrada. Já na direção radial $\left(T_{r r}\right)$, há gradiente de temperatura, porém a superfície é livre para a dilatação do material sem restrições, gerando tensões nulas na superfície e, abaixo dela, de magnitude significativamente menor às tensões nas outras direções. Em regiões onde apenas uma das direções de tensão é significativa, a malha de trincas obtém a forma de linhas paralelas ${ }^{[49]}$.

A literatura geralmente divide o estudo da fadiga em termos de vida em fadiga $\left(N_{f}\right)$ como Fadiga de alto ciclo ou Fadiga de baixo ciclo, após a criação do último termo por Coffin e Manson ${ }^{[51]}$. O que diferencia os dois modos de fadiga são, basicamente a forma de deformação predominante. Na fadiga de alto ciclo, predominam as tensões elásticas e a deformação plástica ocorre de forma discreta e localmente em um concentrador de tensões. O número de ciclos para falha ultrapassa uma faixa de $10^{4}$ a $10^{5}$. Na presença de tensão e deformação predominantemente plásticas a fadiga é de baixo ciclo, com fratura ocorrendo em menos de $10^{4}$ a $10^{5}$ ciclos geralmente. Como pode ser deduzido, as tensões máximas na fadiga de baixo ciclo são maiores que nas 


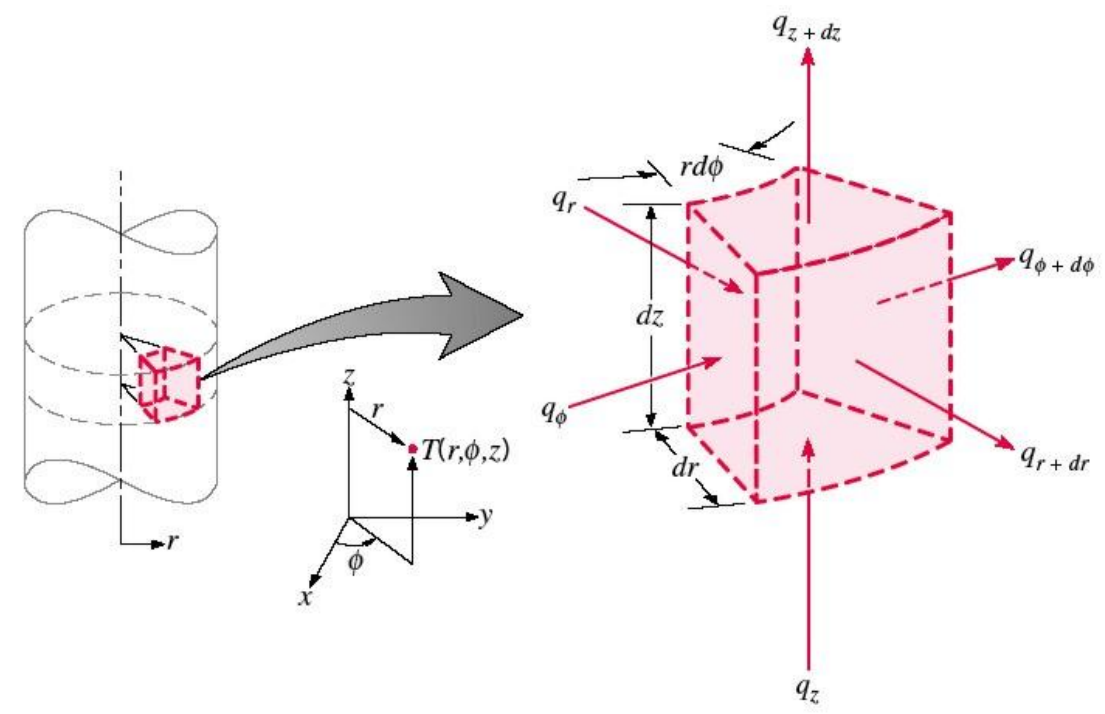

Figura 2.8: Representação de um volume de controle diferencial para análise de transmissão de calor em coordenadas cilíndricas ${ }^{[50]}$. As direções $r, \theta$ e $z$ são chamadas, respectivamente, de radial, circunferencial e axial.

de alto ciclo. ${ }^{[44]}$ Em termos de vida em fadiga $\left(N_{f}\right)$, o fenômeno de fadiga térmica é considerado Fadiga de baixo ciclo, com tensões maiores que o limite de escoamento do material, lembrando que o limite de escoamento diminui em função do aumento da temperatura.

\subsubsection{Tensões térmicas ${ }^{[5]}$}

Em geral, as tensões térmicas são abordadas pela literatura partindo da deformação de um componente gerada pelo seu resfriamento ou aquecimento (contração ou dilatação do componente) para, a partir daí, apresentar as equações que regem as tensões desenvolvidas sob solicitações uniaxial e biaxial $^{[41,52-54]}$. A mesma abordagem será utilizada nesta revisão.

Se uma barra de comprimento $L$ é resfriada de uma temperatura $\left(T_{0}\right)$ para outra $\left(T_{1}\right)$, ela irá contrair segundo a equação:

$$
\Delta L=\alpha\left(T_{1}-T_{0}\right) L
$$

onde $\alpha$ é o coeficiente de expansão térmica linear do material da barra.

A deformação sofrida pela barra, no sentido do comprimento, é definida como

$$
\varepsilon=\frac{\Delta L}{L}=\alpha\left(T_{1}-T_{0}\right)
$$

e, portanto, a tensão de compressão que age sobre o material é (Lei de Ho- 
oke):

$$
\sigma_{c}=E \varepsilon=E \alpha\left(T_{1}-T_{0}\right) \quad \text { (negativa) }
$$

onde $E$ é o módulo de elasticidade, módulo de rigidez ou módulo de Young do material da barra.

Entretanto, se as extremidades dessa barra estiverem fixas, de tal forma a restringir a contração, ela ficará submetida a uma tensão de tração de mesmo módulo que a tensão de compressão:

$$
\sigma=-\sigma_{c}=E \alpha\left(T_{0}-T_{1}\right) \quad(\text { positiva })
$$

É importante deixar claro que nenhuma tensão térmica é produzida em um material sólido se o aumento na temperatura é o mesmo em todas as suas partes e se a alteração no volume não sofre nenhuma restrição. ${ }^{[55]}$

No caso de uma chapa com largura e comprimento similares e muito maiores do que a espessura, em que a restrição à contração é aplicada no próprio plano da chapa, desenvolve-se um estado plano de tensões com

$$
\sigma=\frac{E \alpha \Delta T}{1-\nu}
$$

onde $\nu$ é o coeficiente de Poisson e $\Delta T=T_{1}-T_{0}$.

É importante ressaltar que essas equações foram baseadas na hipótese de que todo o componente passa de uma temperatura para outra instantaneamente, ou seja, não há gradiente térmico ao longo do corpo nas temperaturas consideradas. Pode-se considerar, portanto, que esta última situação é similar à de um corpo em que uma fina camada superficial é submetida a variações cíclicas de temperatura entre $T_{0}$ e $T_{1}$, em que a limitação à deformação (contração e dilatação) é imposta pelo interior (bulk) do próprio componente que se mantém a uma temperatura constante.

Para um caso mais específico, como um material compósito, as tensões variam diretamente com as diferenças entre os coeficientes de expansão térmica das suas fases ou constituintes. Considerando um material com deposição de uma fina camada em sua superfície, a Equação (2.5) pode ser escrita da seguinte forma ${ }^{[56]}$ :

$$
\sigma=\frac{E \cdot \Delta \alpha \cdot \Delta T}{1-\nu}
$$

sendo $\Delta \alpha$ a diferença entre os coeficientes de expansão térmica do substrato e da camada. A fase ou constituinte que possuir o maior valor do coeficiente de expansão térmica será a fase que estará sob tração no resfriamento. 
Por exemplo, em materiais que possuem aplicação de uma camada cerâmica para atuar como barreira térmica, como é o caso de palhetas de turbina a gás, a falha em serviço ocorre por meio de decoesão seguida de descolamento da camada cerâmica. Isso ocorre em função da diferença entre os coeficientes de expansão térmica da camada (menor $\alpha$ ) e do substrato (maior $\alpha$ ), que promove a tensão de tração no substrato, nucleando trincas na interface substrato/matriz ${ }^{[52]}$. Para outras estruturas de compósitos, como pode ser entendida a microestrutura de um aço com dispersão de carbonetos primários, as tensões geradas pela diferença de expansão térmica são mais complexas, multidirecionais, e envolvem as propriedades térmicas e elásticas de cada fase presente ${ }^{[56]}$.

\subsubsection{Nucleação e propagação de trincas}

As trincas de fadiga nucleiam nas superfícies livres de metais expostos ao carregamento cíclico, seja por meio de tensão externa aplicada ou tensão gerada por mudanças de temperatura. Isso ocorre porque a deformação plástica cíclica é supostamente maior nas superfícies livres, devido às maiores tensões desenvolvidas e ao menor grau de restrição à deformação dessas regiões gerado pelas regiões vizinhas (os grãos da superfície possuem menos grãos vizinhos para limitar a deformação plástica). ${ }^{[5]}$

Entretanto, as trincas também podem ser nucleadas em defeitos internos ou segundas fases da microestrutura, dependendo da concentração de tensão que esses elementos causam.

Há basicamente quatro tipos de sítios para a nucleação de trincas de fadiga:

- Bandas persistentes de deformação (geradas durante o processo de carregamento cíclico);

- Contornos de grão;

- Partículas de segunda fase;

- Defeitos internos.

Inclusões e partículas de carboneto são conhecidos sítios iniciadores de trincas de fadiga, além de gerarem defeitos superficiais. Tang et al. ${ }^{[57]} \mathrm{e}$ Meurling et al. ${ }^{[58]}$ concluíram que, quanto mais homogênea a microestrutura 
do aço, melhor o seu comportamento em fadiga. Meurling et al. investigaram quatro aços para trabalho a frio com respeito à fadiga, variando-se o conteúdo de inclusões e carbonetos, e verificaram que, na maioria dos casos, as trincas de fadiga iniciam no interior das amostras, nas inclusões, assim como foi também confirmado por Silva ${ }^{[6]}$ e mostrado na Figura 2.2 (pág. 34).

Serantoni ${ }^{[5]}$, ao estudar ferros fundidos brancos multicomponentes, afirmou que a taxa de nucleação sofre influência da fração volumétrica de carboneto eutético (seu aumento promove aumento da taxa de nucleação) e da dureza da matriz (seu aumento promove diminuição da taxa de nucleação) e a propagação de trincas ocorre predominantemente pela interface carboneto/matriz ou através do carboneto. A taxa de propagação sofre influência da distribuição de carboneto eutético, pois quanto maior a relação (comprimento do carboneto)/(distância livre média entre eles), maior a taxa de propagação de trincas.

\subsubsection{Trincas primárias e secundárias}

Ao observar uma ferramenta com danos de fadiga térmica, observam-se duas malhas de trincas interconectadas. Uma malha tem trincas facilmente vistas a olho nu ou por ensaios de líquido penetrante, que podem ser associadas a outros danos mais graves, como arrancamentos de material. A outra malha, com quantidade diferente de trincas, é menos visível e parece se conectar à primeira em alguns pontos. Inicialmente, na prática industrial, foi feita uma suposição de que a segunda malha de trincas derivava da primeira, como ramificações finas das primeiras trincas. Por isso, deu-se o nome de trincas primárias para o primeiro tipo e trincas secundárias para o segundo. ${ }^{1}$ Entretanto, observando com maior atenção o início da formação do dano, notou-se que a malha secundária formava-se antes da malha primária. Mesmo assim, manteve-se essa nomenclatura, que também será utilizada neste trabalho.

Nos ensaios em escala piloto realizados no projeto do IPT, foram construídos cilindros de laminação dos materiais H13 e C99, para registro da forma de evolução dos danos de abrasão, adesão e fadiga térmica que acontecem ao mesmo tempo nas ferramentas.

Ao final de 5 campanhas de laminação, os cilindros foram cortados e amostras foram retiradas de regiões da seção transversal próximas à super-

\footnotetext{
${ }^{1}$ Essa informação foi coletada de forma informal com usuários e fabricantes de ferramentas de conformação a quente.
} 
fície. Essas amostras foram levadas ao microscópio eletrônico de varredura, com o objetivo de observar a formação de trincas de fadiga térmica como ocorrem nas ferramentas durante o serviço.

A Figura 2.9 compara as superfícies dos cilindros de $\mathrm{H} 13$ e de C99, com formação de malhas de trincas primária e secundária. Nos ensaios de fadiga térmica, também foram analisadas essas duas formas de surgimento de trincas.

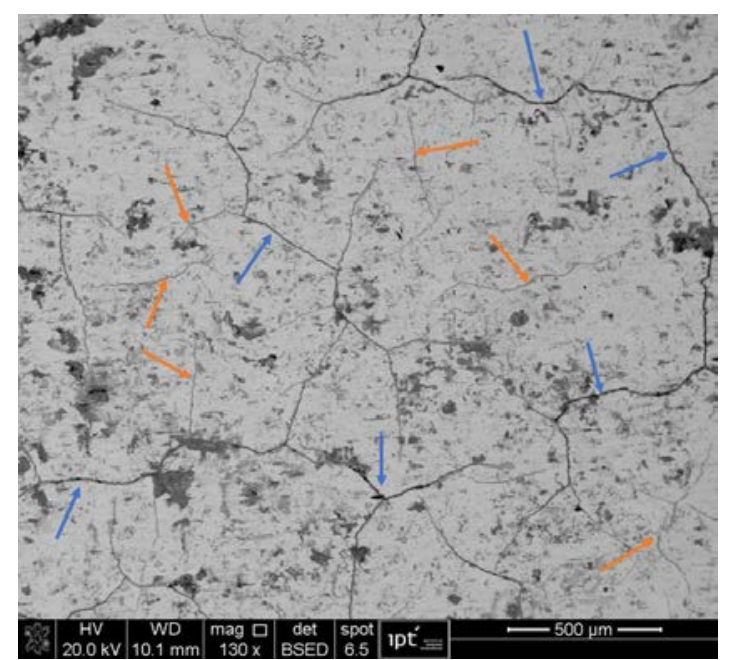

(a)

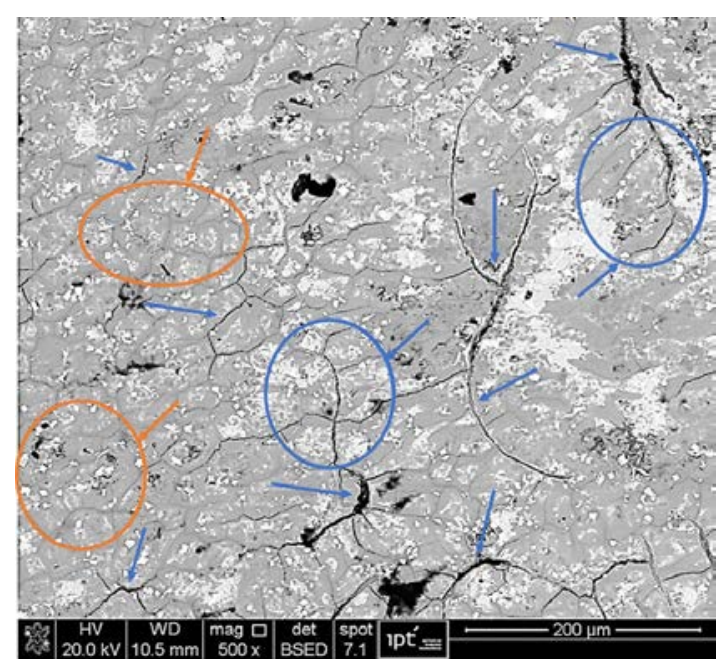

(b)

Figura 2.9: Superfície dos cilindros de laminação de materiais H13 e C99 com danos de fadiga térmica. MEV, Elétrons retroespalhados. As setas azuis indicam trincas primárias, e as laranja indicam trincas secundárias. (a) H13;

(b) C99.

Em corte transversal, é possível diferenciar pontos onde há oxidação profunda, associadas à malha secundária, de regiões efetivamente trincadas, da malha primária. Vêem-se duas ocorrências como essas na Figura 2.10. 


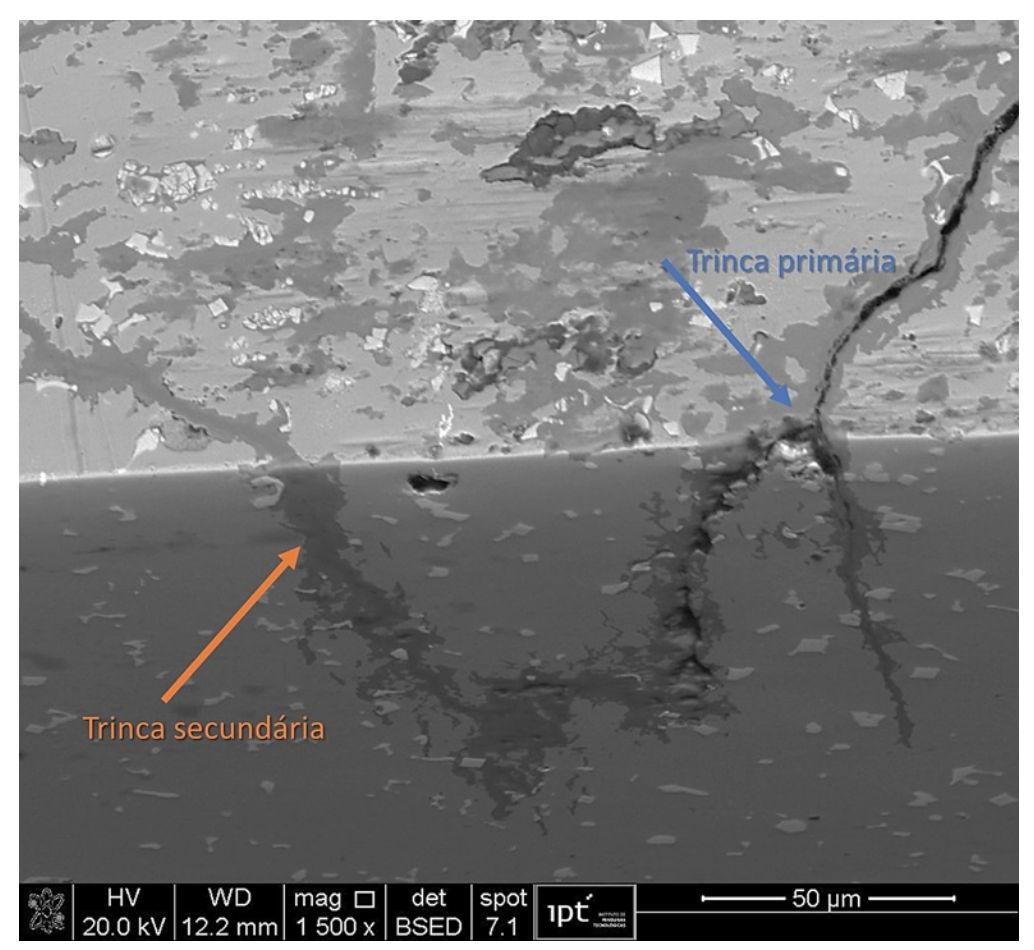

Figura 2.10: Danos no cilindro de C99, em seção transversal. A vista em ângulo mostra, na parte superior, a superfície; na parte inferior, o corte polido. As trincas, como as da direita, propagam pelos filmes de óxido, como o da esquerda.

\subsubsection{Diferenças entre fadiga mecânica e fadiga térmica}

São muito frequentes os trabalhos que estudam a fadiga térmica reduzindoa a uma singularidade da fadiga mecânica. Os argumentos mais frequentes são:

- O cálculo das tensões e deformações de compressão e tração causadas pelo ciclo térmico pode ser simplificado pelo gradiente térmico imposto à superfície;

- Os mecanismos de acúmulo de deformação plástica associados à fadiga mecânica de baixo ciclo podem ser associados à fadiga térmica: ${ }^{[59]}$

- A oxidação, quando não é neglicenciada, é encarada como fadiga de filmes finos, que sofrem delaminação;

- O aquecimento da superfície gera revenimento da microestrutura, que afeta negativamente as propriedades mecânicas do material.

$\mathrm{Na}$ verdade, esses mecanismos podem explicar os casos extremos, em que um desses modos de falha se destaca como, por exemplo, choques térmicos ou formação de camada de óxido espessa. Entretanto, há características 
que são típicas da fadiga térmica e de seus ensaios e há características da fadiga mecânica que não podem ser associadas à fadiga térmica.

Uma delas é o fato de que não é possível estabelecer um carregamento uniaxial de tensão térmica, como é feito no ensaio de fadiga mecânica. A propagação de calor a partir do ponto ou plano de aquecimento/resfriamento do material é sempre não-uniforme, gerando gradientes de temperatura e tensão em todas as dimensões. A segunda característica da fadiga térmica é a forma de apresentação das trincas, que é tipicamente conhecida como heat checking ou cell type cracking ${ }^{[49]}$ (Figura 2.11).

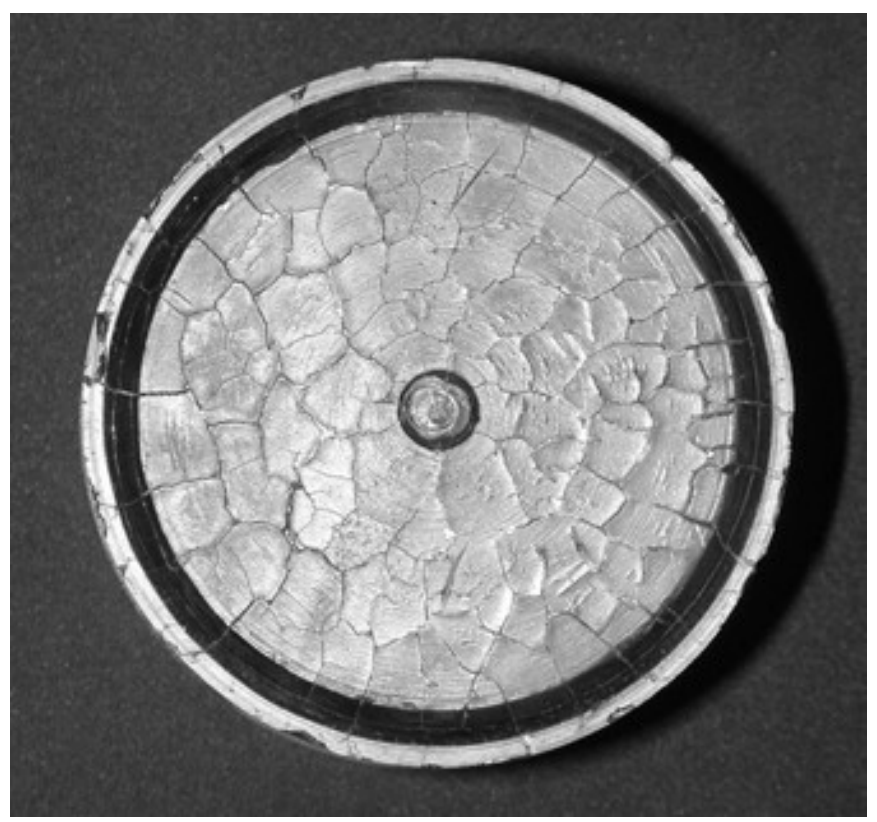

Figura 2.11: Malha de trincas de fadiga térmica (heat checking) observada em um pistão industrial. ${ }^{[3]}$

A complexidade do estado de tensões é agravada pelo fato de que a temperatura determina a maioria das propriedades dos materiais, como dureza, limite de escoamento, condutividade térmica e outras propriedades que devem ser consideradas no cálculo de deformação durante a ciclagem térmica. O gradiente complexo de temperaturas está associado a um gradiente complexo de propriedades do material. Tal distribuição de temperaturas, propriedades mecânicas, propriedades térmicas e deformações só pode ser adequadamente estimada através de cálculo por modelos matemáticos (p.e. elementos finitos) utilizando dados do material levantados em medições a frio e a quente. Cálculos simplificados devem sempre supor sua incompletude.

Por último, é importante lembrar do efeito da temperatura no acúmulo de discordâncias geradas na deformação plástica, causando um efeito de recuperação da microestrutura durante a parte quente do ciclo térmico. 


\subsection{Métodos de ensaio de fadiga térmica}

\subsubsection{Aspectos gerais}

Não existem padrões de geometria de corpo de prova, métodos e temperaturas de aquecimento, resfriamento etc. para os ensaios de fadiga térmica. Logo, o ensaio desenvolvido em uma pesquisa busca sempre reproduzir com maior fidelidade e repetitividade as condições de uso do material em estudo durante o seu uso (p.e. discos de freio, cilindros de laminação, coquilhas).

Os experimentos de fadiga são convencionalmente conduzidos alternandose um dos três parâmetros em um corpo de prova até que a falha ocorra: a tensão, a deformação ou a temperatura, que podem ser programadas para variar com o tempo, como mostra a Figura 2.12, para produzir o ciclo tensãodeformação ou tensão-temperatura apropriado. ${ }^{[55]}$

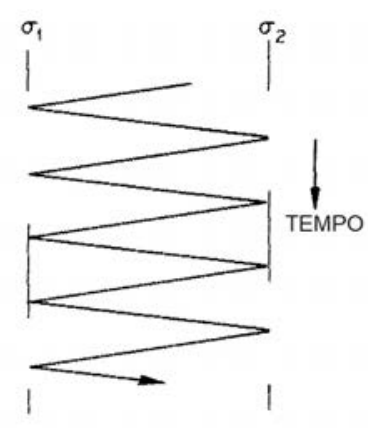

CICLO DE TENSÕES

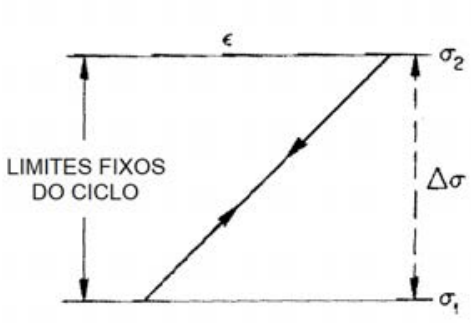

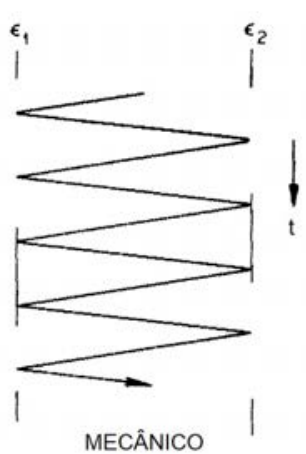

CICLO DE DEFORMAÇÕES

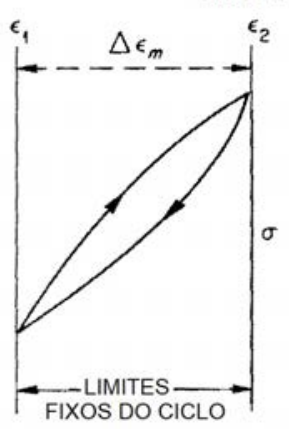

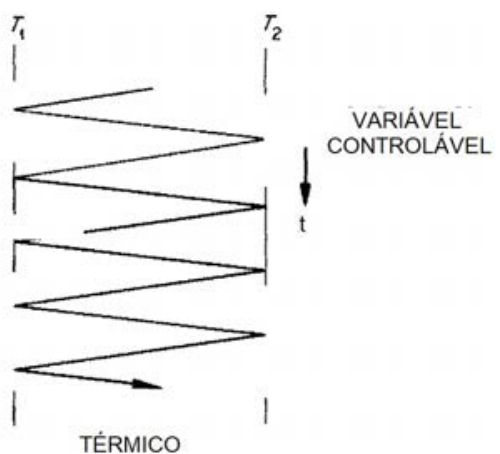

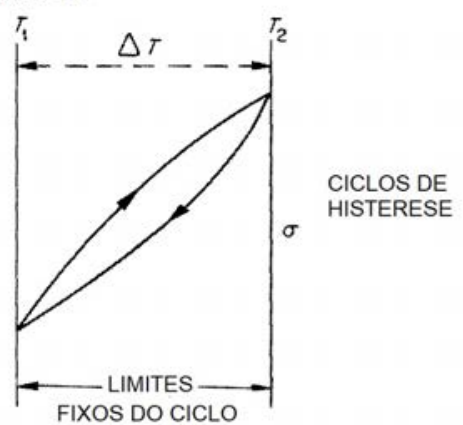

Figura 2.12: Três tipos de teste de fadiga, de acordo com o tipo de carregamento ${ }^{[55]}$ : controle de tensão (esquerda) e deformação - mecânica (centro) e térmica (direita).

Para carregamento cíclico sob condições de comportamento elástico, somente uma linha simples existe no diagrama tensão-deformação; os caminhos do carregamento e do descarregamento são idênticos. A tensão é geralmente a variável significativa na região elástica do carregamento cíclico.

Para fadiga de baixo ciclo ou alta tensão de materiais dúcteis, a variável 
importante é a deformação, e talvez mais precisamente, a deformação plástica. Além disso, equações empíricas podem ser deduzidas a partir de testes de laboratório que descrevam o comportamento em fadiga do material sob uma específica série de condições de deformação cíclica. O termo "fadiga termomecânica" é aplicado a testes onde a temperatura é constante e a deformação mecânica é a variável programada. No teste de fadiga térmica, a temperatura é a variável programada, sem aplicação de cargas mecânicas externas.

Os problemas de medir diretamente as deformações durante o ciclo térmico são complexos. A determinação do ciclo tensão-deformação torna-se dedutiva pelos cálculos de dilatação térmica. A temperatura na metade do comprimento da amostra, o carregamento axial e a posição das extremidades da amostra são geralmente as únicas medidas disponíveis.

\subsubsection{Configurações de ensaio}

A seguir, são apresentados exemplos entre as diversas configurações e condições de ensaio utilizadas nos trabalhos experimentais em que se estudou a fadiga térmica de aços, destacando-se os seguintes pontos:

1. Material e aplicação estudados

2. Geometria e preparação do corpo de prova

3. Método de aquecimento e resfriamento

4. Instrumentação do equipamento e corpo de prova

(a) Medição de temperatura

(b) Medição de deformação/tensões

5. Método de avaliação do dano

\subsubsection{Bergström ${ }^{[60-62]}$}

Bergström, Persson, Hogmark e Sjöström ${ }^{[60-62]}$ usaram nos estudos aços ferramenta martensíticos ${ }^{1}$ (similares ao H13), fabricados pela Uddeholm. Para simular as condições de trabalho de moldes para injeção, os corpos de prova

\footnotetext{
${ }^{1}$ DIEVAR, Hotvar e QRO 90 Supreme
} 
para ensaio de fadiga escolhidos são cilindros de $80 \mathrm{~mm}$ de comprimento (Figura 2.13), usinados a partir de barras, com um diâmetro externo de $10 \mathrm{~mm}$ e um furo central de $3 \mathrm{~mm}$ de diâmetro utilizado para refrigeração interna. Os corpos de prova foram pré-oxidados antes dos testes, para criar uma fina camada de óxido que torna as medições de temperatura durante o aquecimento mais precisas. Uma bobina de indução (25 kW, $3 \mathrm{MHz}$ ) aquece aproximadamente os $20 \mathrm{~mm}$ centrais do bastão de teste. O resfriamento é feito continuamente por silicone ou água que passam através do furo central. A atmosfera foi variada entre ar calmo e argônio.

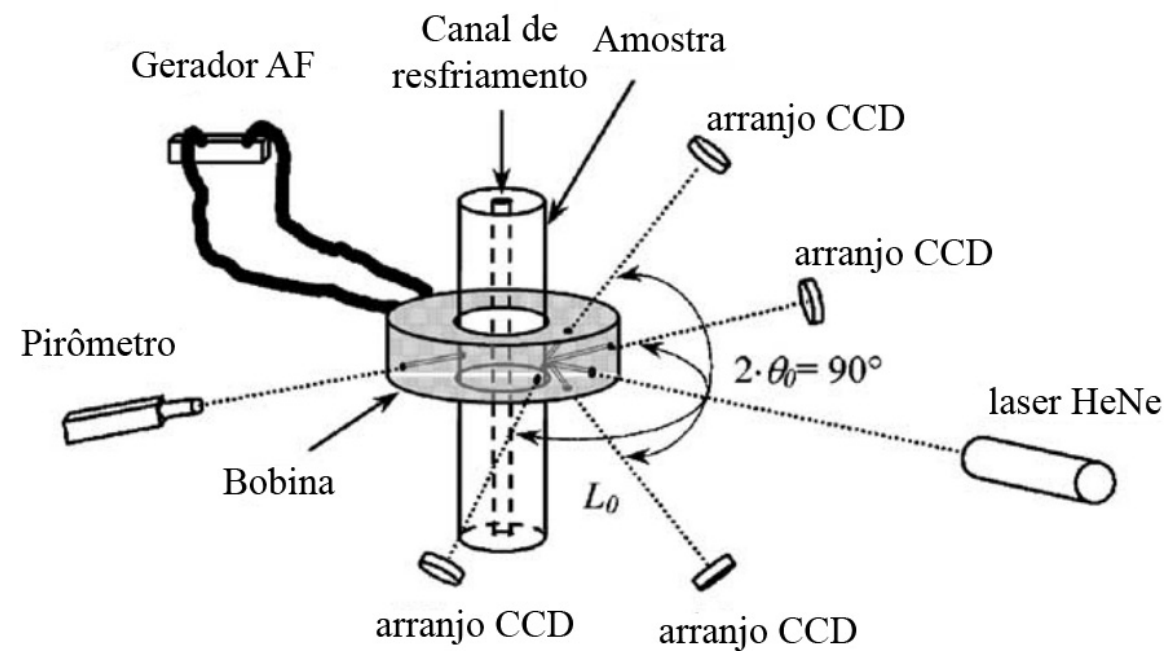

Figura 2.13: Corpo de prova para ensaio de fadiga utilizado por Bergstrom et al. $^{[60-62]}$

A temperatura da superfície é monitorada por um pirômetro, mas também é medida por um termopar, o qual é soldado a um ponto da superfície. O primeiro método foi usado para controlar a temperatura durante o aquecimento, enquanto o último para obter registros da temperatura superficial durante a ciclagem térmica, o que mais tarde foi usado para estimativas de deformações superficiais. O ciclo térmico utilizado consistia de um aquecimento rápido, seguido de um tempo de espera e então pelo resfriamento até a temperatura mínima.

Os pesquisadores usaram o padrão de imagem formado pela superfície oxidada para realizar a medição direta da deformação superficial em duas direções (axial e tangencial), através de um arranjo de câmeras CCD e um feixe de laser.

Os danos de fadiga térmica, após os ensaios, foram revelados por microscopia eletrônica de varredura (MEV). Em seguida, seções axiais transversais polidas foram utilizadas para caracterizar via microscopia óptica (MO) o cres- 
cimento de trinca (comprimento da trinca vs. número de ciclos) e densidade de trincas (número de trincas por unidade de comprimento ao longo da superfície da amostra). Os perfis de dureza vs. profundidade após exposição à ciclagem térmica foram obtidos. Finalmente, mediu-se o estado de tensões residuais na camada superficial por difração de raios-X (DRX).

O primeiro resultado observado, comparando-se amostras ensaiadas em temperaturas de $600^{\circ} \mathrm{C}, 700^{\circ} \mathrm{C}$ e $850^{\circ} \mathrm{C}$ em argônio, foi a diferente morfologia das trincas. Nos primeiros casos, o caminho das trincas era relativamente reto, perpendicular à superfície; no ensaio com temperatura maior, houve ramificações da trinca durante a propagação. O tamanho e a densidade das trincas eram proporcionais à temperatura de aquecimento e ao número de ciclos. Entretanto, a densidade de trincas estabiliza durante o ensaio, enquanto o tamanho continua a aumentar. Com algumas exceções, o comprimento e a densidade das trincas tenderam a diminuir com o aumento da dureza. Os ensaios ao ar mostraram as mesmas tendências de comportamento do material com a temperatura e o número de ciclos.

A forma com que os autores apresentaram os resultados de dureza não proporciona boa base para comparação dos resultados, uma vez que a influência da temperatura e do número de ciclos deveria ter sido apresentada separadamente. No entanto, eles chegaram à conclusão de que a perda de dureza é parcial próxima à superfície nas amostras ensaiadas a $700^{\circ} \mathrm{C}$, enquanto é desprezível nos ensaios a $600^{\circ} \mathrm{C}$ e generalizada nos ensaios a $850^{\circ} \mathrm{C}$. O tempo de espera em alta temperatura após o aquecimento pode ser a causa da espessura afetada pelo calor, já que a alta frequência de indução (3 MHz) utilizada limita o aquecimento a uma espessura muito pequena próxima à superfície.

Os autores associaram a nucleação das trincas não somente à perda gradual de dureza da superfície, mas deram atenção também à concentração de tensões gerada por características topográficas ou inomogeneidades do material, como inclusão de escória, carbonetos ou vazios. A estabilização do número de trincas foi atribuída ao alívio de tensões gerados pela presença de uma trinca sobre a região vizinha. As comparações entre materiais diferentes limitaram-se à comparação de durezas. Finalmente, os autores reforçam que não há influência notável do ambiente de teste nas características das trincas. 


\subsubsection{Brandim et al. ${ }^{[2]}$}

Os brasileiros Brandim et al. ${ }^{[2]}$, visando avaliar a vida em fadiga de novas ligas utilizadas pelo processo de soldagem para várias aplicações tecnológicas, escolheram o material aço inoxidável martensítico 423Co, com a geometria cilíndrica de pequeno diâmetro, como mostra a Figura 2.14. O diâmetro da seção reduzida foi de $3 \mathrm{~mm}$, para garantir que a temperatura fosse obtida tanto com pirômetros ópticos, como por termopares, na superfície e no seu interior, respectivamente, além de ser um valor de diâmetro compatível com a espessura de cordões de solda. As tensões térmicas foram calculadas a partir dos dados de temperatura armazenados em um computador.

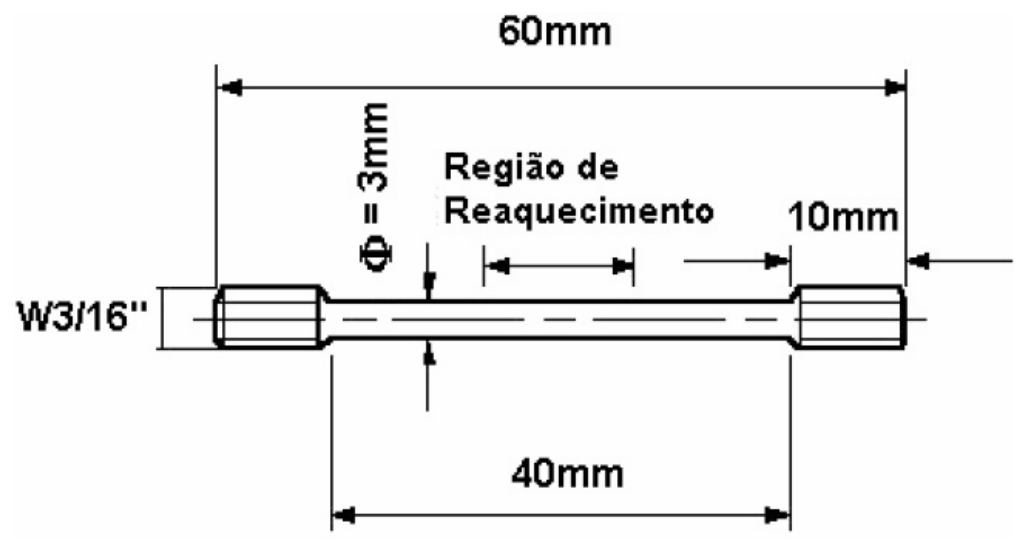

Figura 2.14: Corpo de prova para ensaio de fadiga térmica utilizado por Brandim et al. ${ }^{[2]}$.

Elaborou-se um equipamento de ensaio em uma mesa giratória (ver Figura 2.15) em que se fixam diversos corpos de prova dispostos sobre células de carga (Figura 2.15a), com o movimento longitudinal restrito. Fora da mesa, fixaram-se dois maçaricos, usando GLP e oxigênio como gases combustíveis, e dois bicos aspersores de água ajustáveis, que realizam o aquecimento e o resfriamento do corpo de prova, respectivamente (Figura 2.15b). A velocidade de rotação da mesa foi ajustada de modo que o aquecimento fosse feito em 4,5 s e o resfriamento, em $6 \mathrm{~s}$. A temperatura máxima nos corpos de prova variou entre 600 e $700^{\circ} \mathrm{C}$ e a temperatura mínima na faixa de 25 a $50^{\circ} \mathrm{C}$, semelhante às condições de operação de rolos de lingotamento contínuo.

Os autores atestaram, pelas medições de força e temperatura, que os ciclos de carregamento e de temperatura estão fora de fase, porém atribuem esse comportamento às restrições externas de movimentação do material nos dois extremos, enquanto a literatura de fadiga térmica atribui a geração de tensões às restrições internas associadas aos gradientes térmicos. 


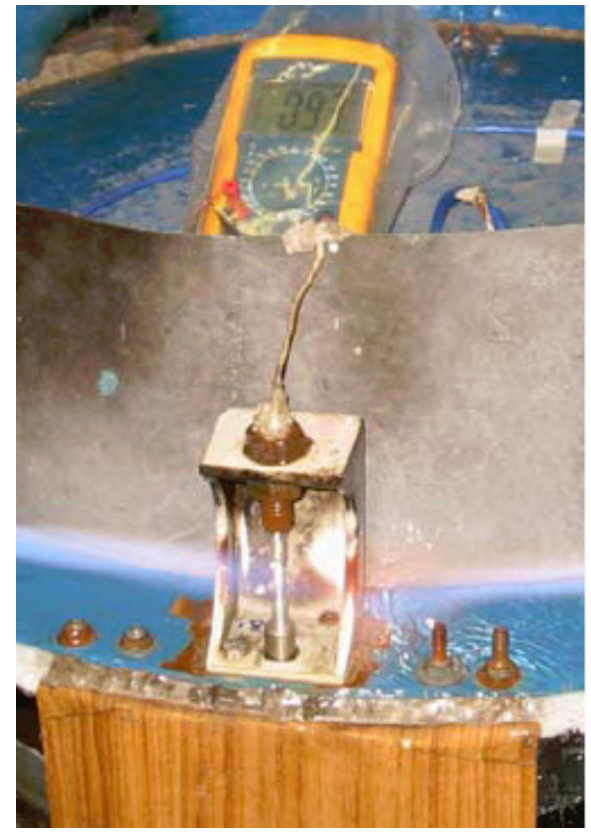

(a)

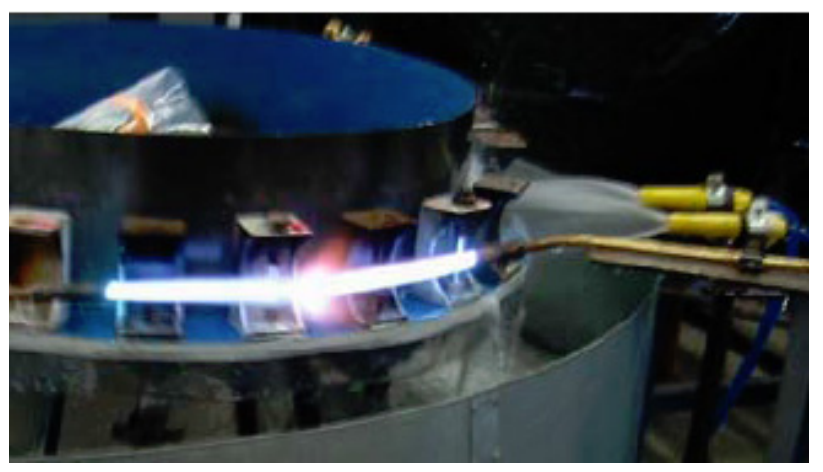

(b)

Figura 2.15: Equipamento de fadiga térmica usado por Brandim et al. : (a) Corpo-de-prova disposto sobre a célula de carga; (b) Estação de aquecimento, realizado pelos maçaricos, e de aquecimento, por bicos aspersores de água. ${ }^{[2]}$

Os corpos de prova não foram caracterizados em relação à formação de trincas. O ensaio serviu para avaliar o efeito da temperatura na geração de tensões sobre as células de carga que restringiam o movimento linear dos corpos de prova. Verificou-se que o ensaio de fadiga térmica apresenta três estágios bem definidos:

I - Comportamento Elástico Com duração de apenas 3 ciclos, nos quais a tensão de compressão é crescente, porém abaixo do limite de escoamento, dentro do regime elástico do material;

II - Transição Com duração de 50 ciclos, onde o corpo de prova é induzido termicamente a pequenas e contínuas taxas de deformação plástica em compressão em condições de difícil redistribuição de discordâncias, até atingir uma condição de alteração do limite de escoamento (o efeito Bauschiger). A tensão média deixa de ser compressiva e passa a ser trativa até se estabilizar no final do estágio;

III - Estabilidade Considera-se encurtamento do corpo de prova devido à deformação plástica, diminuindo a restrição ao movimento longitudinal causado pela montagem experimental. O material permanece num estado de tensão média de tração gerada no resfriamento. 
Concluiu-se também que durante o ensaio de fadiga térmica sob condição de restrição total ocorre a diminuição da tensão de compressão e aumento da tensão de tração, que resulta no aumento da tensão média, reduzindo a vida útil à fadiga térmica.

Tais suposições de mecanismos propostos pelos autores não foram fundamentados em forte discussão baseada na literatura, portanto devem ser considerados com cautela.

\subsubsection{Caliskanoglu et al. ${ }^{[63]}$}

Caliskanoglu et al. ${ }^{[63]}$ realizaram experimentos de fadiga térmica e de amolecimento isotérmico para caracterizar o comportamento do aço DIN X38CrMoV53. Eles usaram modelamento de elementos finitos para determinar o carregamento térmico cíclico. Modelamento microestrutural foi usado para estimar os efeitos dos ciclos térmicos nas alterações microestruturais.

Um equipamento de teste (Figura 2.16) foi especialmente projetado para investigar o comportamento de fadiga térmica de aços ferramenta. O corpo de prova em forma de disco foi testado em uma câmara de vácuo para prevenir a oxidação da superfície aquecida. O corpo de prova foi fixado mecanicamente a um sistema de montagem de cobre termicamente controlado, mantido à temperatura constante de $200{ }^{\circ} \mathrm{C}$. O aquecimento superficial cíclico foi feito usando-se um laser de diodo pulsado com uma potência máxima de 1,8 kW. A radiação do laser foi guiada por uma fibra óptica, uma unidade de foco e uma janela transparente até o corpo de prova e uma área circular com diâmetro de aproximadamente $1 \mathrm{~mm}$ foi irradiada. A radiação do laser refletida era absorvida por um defletor de feixes resfriado a água. A temperatura na zona de interação foi controlada com um pirômetro que operava entre 250 e $1300{ }^{\circ} \mathrm{C}$, com um tempo de resposta de $15 \mu \mathrm{s}$. Um filtro espectral no sistema óptico do pirômetro prevenia os efeitos da radiação refletida e espalhada. Usou-se um osciloscópio para exibir os ciclos térmicos e fornecer uma interface com um PC.

Para os estudos de fadiga térmica, diferentes energias de pulso foram escolhidas para atingir temperaturas superficiais máximas de 475,575 e $650^{\circ} \mathrm{C}$, com tempos de irradiação de 1,5 e 4,5 s com um intervalo entre os pulsos de $1,5 \mathrm{~s}$. Todos os testes foram realizados a uma temperatura de fundo de $200^{\circ} \mathrm{C}$.

Os cálculos de deformação total realizados para as 4 condições de aqueci- 


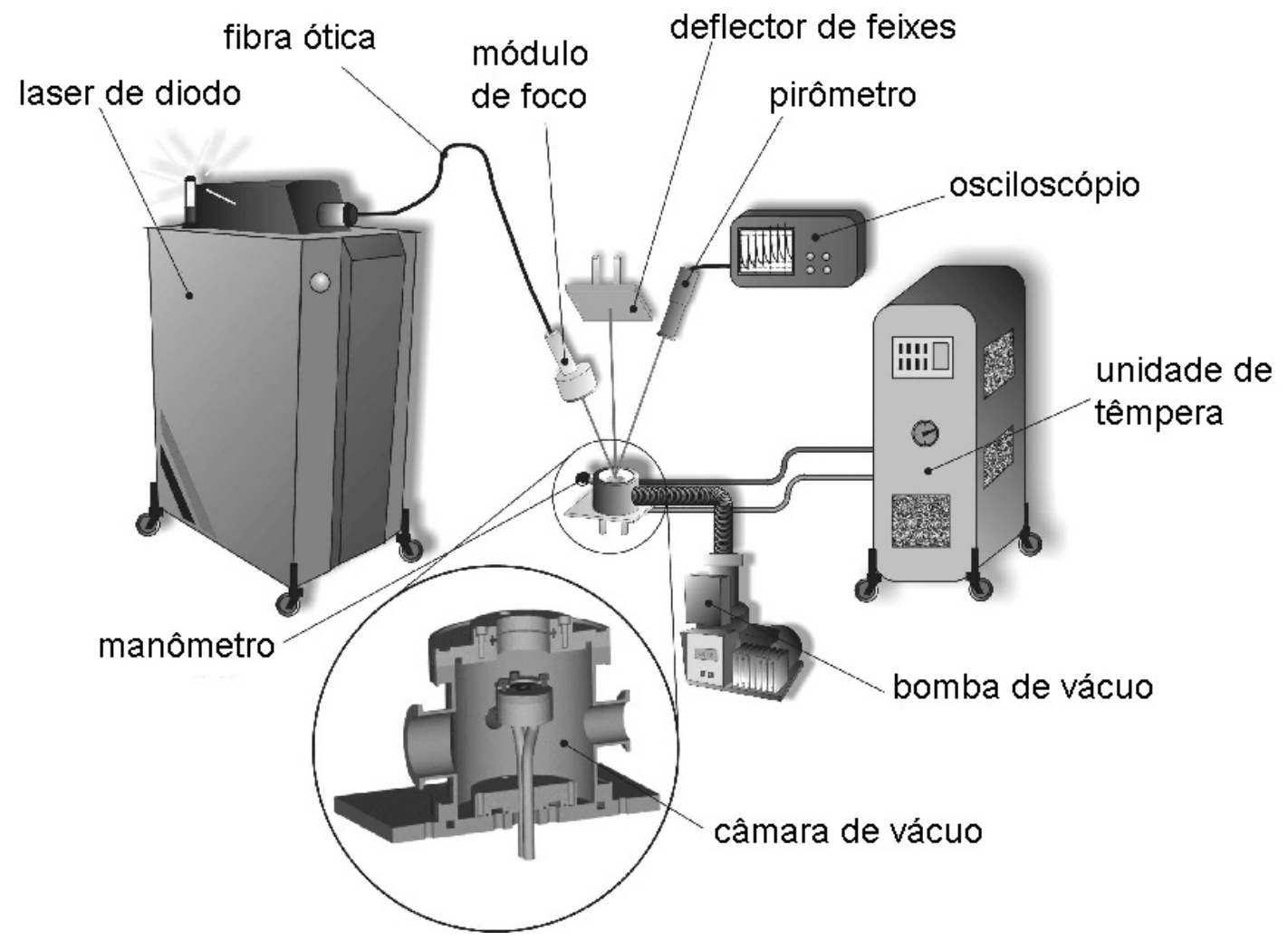

Figura 2.16: Arranjo experimental utilizado por Caliskanoglu et al. 0 aquecimento superficial cíclico foi feito usando-se um laser de diodo pulsado, guiado por uma fibra óptica, uma unidade de foco e uma janela transparente até o corpo de prova em uma área circular com diâmetro de aproximadamente $1 \mathrm{~mm} .^{[63]}$

mento, variando temperatura e tempo de aquecimento (para $575^{\circ} \mathrm{C}$ ) mostram que a deformação é maior para as maiores temperaturas e diminui com o aumento do tempo de aquecimento. Segundo os autores, isso é causado por um menor gradiente de temperaturas devido ao menor fluxo de calor no caso da maior duração do pulso.

As mudanças no material foram caracterizadas apenas pelas alterações na dureza, como resultado do número de ciclos térmicos. Medidas de dureza realizadas após números programados de ciclos durante os ensaios de fadiga térmica mostraram amolecimento do material apenas nas temperaturas $575 \mathrm{e}$ $650^{\circ} \mathrm{C}$. O tempo de aquecimento também influenciou na perda de dureza, que foi maior na situação de aquecimento mais lento, levando à conclusão de que a taxa de deformação deve ter um papel importante no processo de dano.

\subsubsection{Medjedoub e Rézaï-Aria et al. ${ }^{[3,49]}$}

Medjedoub ${ }^{[3]}$, trabalhando com Rézaï-Aria et al. ${ }^{[49]}$ no estudo de moldes para fundição sob pressão, estudou o aço ferramenta de trabalho a quente 


\section{X38CrMoV5.}

Desenvolveu-se um método de ensaio de fadiga térmica que utiliza corpos de prova tubulares cilíndricos com uma espessura de $10 \mathrm{~mm}$ na área ativa (Figura 2.17). A superfície externa de cada tubo, de $30 \mathrm{~mm}$ de diâmetro, é polida para obter uma rugosidade de $R_{a}=0,2 \mu m$. A superfície interna é retificada.
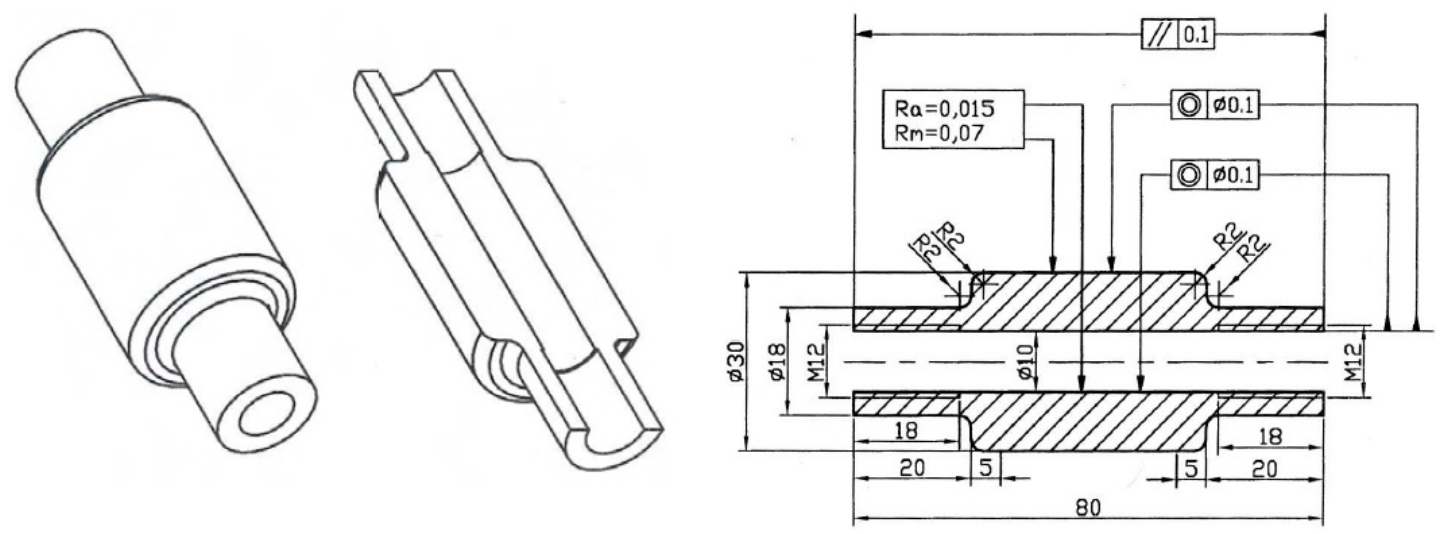

Figura 2.17: Corpo de prova para ensaio de fadiga térmica utilizado por Medjedoub e Rézaï-Aria (medidas em $\mathrm{mm}$ ). O corpo de prova tem diâmetro externo de $30 \mathrm{~mm}$ e comprimento de $40 \mathrm{~mm}$ na área de aquecimento. $\mathrm{O}$ acabamento da superfície externa é polido e a superfície interna é retificada. Os pescoços têm diâmetro de $18 \mathrm{~mm}$ e comprimento de $20 \mathrm{~mm}$, com roscas para fixação de mangueiras para refrigeração interna. ${ }^{[3,49]}$

O arranjo experimental de fadiga térmica é baseado nos princípios de aquecimento por indução e resfriamento ao ar. Um gerador de alta frequência, com uma potência nominal de $25 \mathrm{~kW}$, com uma faixa de frequência de 80 a $300 \mathrm{kHz}$, pode atingir temperaturas de cerca de $700^{\circ} \mathrm{C}$ na superfície externa das amostras. Foram utilizadas temperaturas máximas variadas entre $500 \mathrm{e}$ $685^{\circ} \mathrm{C}$. O resfriamento pelo ar é conseguido "ao natural”, ou seja, sem ar soprado (temperatura mínima $100^{\circ} \mathrm{C}$ ). O resfriamento da superfície interna das peças é conseguido através da água que circula com uma vazão constante de $20 \mathrm{l} / \mathrm{min}$ e uma temperatura média de $20^{\circ} \mathrm{C}$.

O tempo de aquecimento dos corpos de prova é inferior a 1 segundo, o que exigiu um sistema de aquisição de dados de temperatura com armazenamento rápido em um computador. Os dados foram adquiridos através de termopares tipo $\mathrm{K}$ de 0,1 e 0,2 $\mathrm{mm}$ de diâmetro soldados, respectivamente, à superfície e à profundidade da amostra, como mostra a Figura 2.18. As deformações e tensões térmicas elásticas e plásticas foram calculadas pelo ABAQUS a partir dos valores de temperatura e propriedades do material.

A caracterização das superfícies das amostras foi feita em MO e MEV, a 


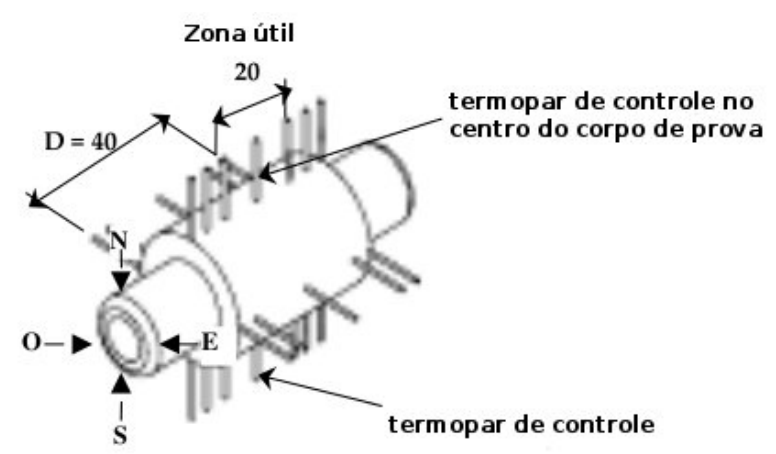

(a) (a)

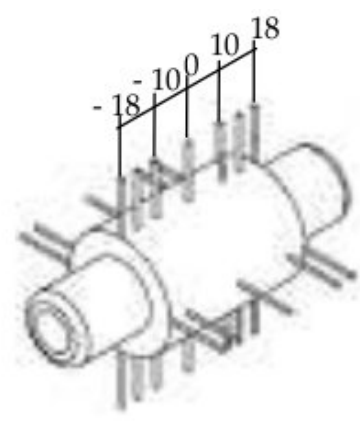

$40 \mathrm{~mm}$
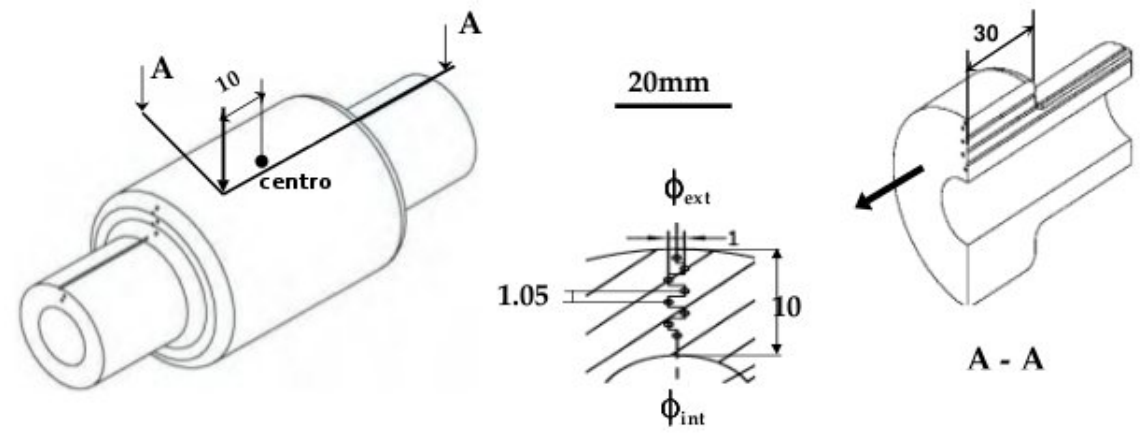

A - A

(b)

Figura 2.18: Instrumentação do corpo de prova para aquisição de dados de temperatura utilizada por Medjedoub e Rézai-Aria. (a) Termopares na superfície tipo K, diâmetro 0,1 mm; (b) Termopares no interior tipo K, diâmetro $0,2 \mathrm{~mm}^{[3,49]}$

fim de determinar:

- O comprimento das macrotrincas e sua evolução em função do número de ciclos.

- A morfologia da camada de óxidos.

- A iniciação da malha de microtrincas, para realização de cartografias no centro da amostra e nas geratrizes.

- A iniciação das macrotrincas na zona útil do corpo de prova.

Os autores observaram que a malha de trincas térmicas (heat checking) se forma cedo e evolui drasticamente até atingir um limite quase-assintótico que permanece inalterado com os ciclos térmicos subsequentes.

A evolução da densidade de microtrincas térmicas com o número de ciclos é influenciada pela temperatura máxima (variação do $\Delta T$ mantendo-se a temperatura mínima sempre igual) e pelo fluxo de calor ( $\Phi$ - indiretamente, a velocidade de aquecimento), mas não pela dureza inicial após diferentes 
tratamentos térmicos. O início da formação das macrotrincas é atribuído à coalescência das trincas isoladas e re-trincamento (sic) de trincas já existentes, formando uma segunda rede de trincas macroscópicas.

Após o fim dos ensaios, também foram preparadas amostras metalográficas da seção transversal. As amostras foram cortadas, embutidas, polidas e atacadas com Nital, para revelar a microestrutura. As trincas então puderam ser medidas, em termos de profundidade, no microscópio óptico (maiores) e eletrônico de varredura (menores), onde também puderam ser feitas medidas de composição química semi-quantitativa por EDS ${ }^{1}$. As medidas de dureza foram feitas em microdurômetro com cargas de 25 a $100 \mathrm{~g}$, ao longo da profundidade.

A oxidação da superfície formou 2 camadas de óxido de espessuras semelhantes. A primeira, próxima ao metal, rica em cromo, e a externa pobre em cromo. Ambas as camadas estavam trincadas pelas microtrincas que formam a malha de trincas secundárias caracterizada. As macrotrincas nucleavam no metal a partir das microtrincas.

A fim de adaptar os resultados de observações de trincas térmicas na superfície, sem a possibilidade de medição de trincas propagando para o interior do material e buscando uma solução de engenharia, foram feitas simplificações na lei de Paris para obter uma previsão de mecanismo de propagação das trincas, utilizando a componente de tensão $\sigma_{\theta \theta}$ e o comprimento de trinca superficial, medido na região de $20 \mathrm{~mm}$ centrais dos corpos de prova. Após outras adaptações e simplificações que são bastante detalhadas na tese de doutorado de Medjedoub ${ }^{[3]}$, foi possível traçar as curvas S-N e da/dN de fadiga térmica do material estudado.

\subsubsection{Serantoni ${ }^{[5]}$}

Serantoni ${ }^{[5]}$, no IPT, utilizou dois modelos de corpo de prova (Figura 2.19) desenvolvidos por uma empresa japonesa ex-fabricante de cilindros de laminação, construídos em diferentes ligas de ferro fundido branco multicomponentes (ligas Fe-Cr-V-Mo-W-C).

Os corpos de prova foram ensaiados sob fadiga térmica a 100 e a 500 ciclos, com uma repetição para cada ensaio. No ensaio, o corpo de prova é transportado alternadamente do interior de uma bobina de indução para

\footnotetext{
${ }^{1} \mathrm{EDS}=$ espectroscopia de dispersão de energia
} 


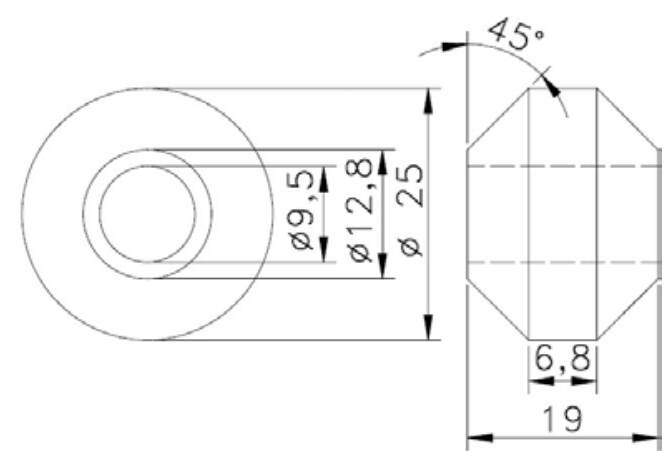

(a)

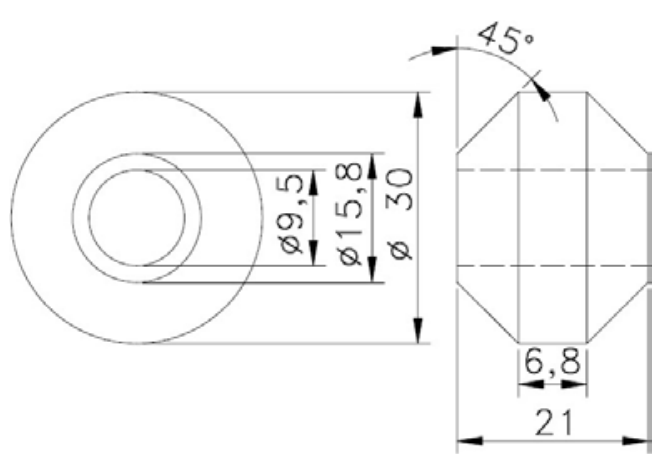

(b)

Figura 2.19: Corpos de prova para ensaio de fadiga térmica utilizados por Serantoni (medidas em mm). (a) CP menor; (b) CP maior, usado apenas na terceira série de experimentos. ${ }^{[5]}$

um tanque de água (e vice-versa) por intermédio de sistema pneumático comandado, no aquecimento, por pirômetro de radiação e, no resfriamento, por temporizador. A quantidade de ciclos é contabilizada por meio de um contador digital localizado no final do curso ascendente do cilindro pneumático. A superfície dos corpos de prova foi aquecida até $600^{\circ} \mathrm{C}$ (temperatura máxima estimada na superfície de cilindros de laminação a quente de tiras de aço) por $10 \mathrm{~s}$, seguindo-se, imediatamente, a imersão em água a temperatura entre 25 e $35^{\circ} \mathrm{C}$ por 45 segundos.

O tempo de resfriamento no interior do tanque de água foi determinado a partir da necessidade de equalizar as temperaturas da superfície e do centro do corpo de prova, eliminando gradientes de temperatura remanescentes dos ciclos anteriores. A Figura $\mathbf{2 . 2 0}$ mostra, esquematicamente, o ciclo térmico aplicado ao corpo de prova durante o ensaio.

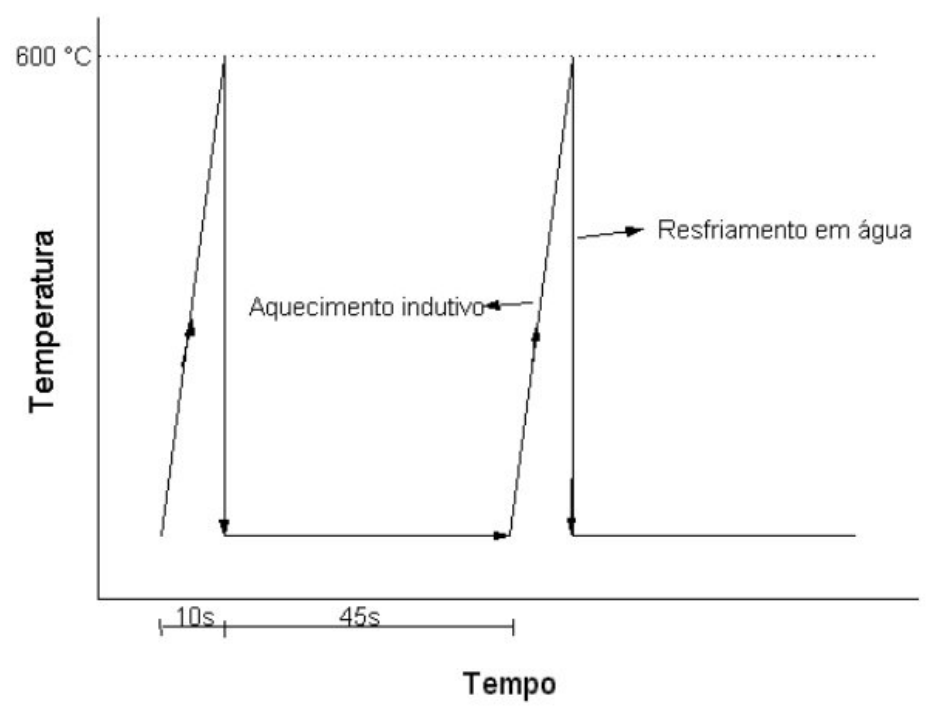

Figura 2.20: Representação esquemática do ciclo térmico aplicado ao corpo de prova utilizado por Serantoni durante o ensaio de fadiga térmica ${ }^{[5]}$. 
A caracterização dos corpos de prova no estado final consistiu de ensaio de líquido penetrante, metalografia qualitativa - para identificar e caracterizar o sítio de nucleação e o caminho de propagação das trincas -, medição da quantidade e profundidade de trincas (em MO) e ensaio de microdureza.

As ligas estudadas foram caracterizadas por metalografia para levantamento dos seguintes parâmetros: Fração volumétrica dos carbonetos eutéticos; fator de forma $(F)$; diâmetro equivalente $\left(\phi_{e q}\right)$ do carboneto eutético $M C$; continuidade $(C)$ e distância livre média entre carbonetos $\left(D_{m}\right)$.

De uma forma geral, os resultados podem ser resumidos desta forma:

(i) Os corpos-de-prova da liga AM (sem carboneto eutético na microestrutura), independentemente da dureza da matriz e do número de ciclos, não apresentaram trincas macroscópicas;

(ii) Os corpos-de-prova das demais ligas (com carboneto eutético na microestrutura) apresentaram trincas radial e circunferencial. Na maior parte dos corpos de prova as trincas são únicas e sem ramificação, sendo que a trinca circunferencial propaga-se preferencialmente pela pista do corpo de prova;

(iii) A oxidação em água foi muito severa (camada da ordem de $10 \mu \mathrm{m}$ após 500 ciclos), o que atrapalhou a contagem de trincas, a comparação entre os ensaios com número de ciclos diferentes e a identificação dos pontos de nucleação de trincas;

(iv) O aumento da fração volumétrica de carboneto MC promove o aumento da densidade de trincas;

(v) A densidade de trincas aumenta com a diminuição da dureza da matriz, independentemente da fração volumétrica de carboneto eutético MC.

(vi) Nas ligas com carbonetos eutéticos, a nucleação das trincas ocorre nos carbonetos eutéticos (mais comum), na interface carboneto/matriz e, ainda, na própria matriz;

(vii) A propagação de trincas ocorre predominantemente pela interface carboneto/matriz ou através do carboneto. A taxa de propagação sofre influência da distribuição de carboneto eutético. Quanto maior a relação $C / D_{m}$, maior a taxa de propagação de trincas. 


\subsubsection{Silva ${ }^{[6]}$}

Poucos anos depois, Silva ${ }^{[6]}$, ao longo de seu trabalho, realizou modificações na máquina de fadiga térmica utilizada por Serantoni ${ }^{[5]}$, envolvendo automação ${ }^{1}$, rotação do corpo-de-prova ${ }^{2}$ e troca do pirômetro de radiação infravermelha ${ }^{3}$. Variaram-se também a temperatura de aquecimento e o número de ciclos por ensaio, realizando-se 100 ciclos por ensaio, com 1 repetição. A superfície dos corpos-de-prova foi aquecida até $650{ }^{\circ} \mathrm{C}$ em $10 \mathrm{~s}$, seguindo-se, imediatamente, pela imersão em água à temperatura entre 25 e $35^{\circ} \mathrm{C}$ por $40 \mathrm{~s}$.

A caracterização dos corpos de prova após o ensaio de fadiga térmica foi feita seguindo a mesma metodologia de Serantoni ${ }^{[5]}$ (Seção 2.5.2.5). As conclusões também foram ao encontro do trabalho de Serantoni, uma vez que os danos de fadiga térmica puderam ser relacionados à microestrutura através do parâmetro $C / D_{m}$. A morfologia dos carbonetos influenciou no parâmetro $C / D_{m}$ e, consequentemente, nas trincas de fadiga térmica, mesmo para amostras com a mesma fração volumétrica de carbonetos $\mathrm{NbC}$.

Outros detalhes sobre o trabalho de Silva estão na Seção 2.2.2, pág. 32.

\subsubsection{Matsumoto $^{[47]}$}

Algum tempo depois, Matsumoto ${ }^{[47]}$, no IPT, desenvolveu uma rotina de estudo sobre a geometria dos corpos de prova utilizados em ensaios de fadiga térmica e trabalhou com cinco diferentes geometrias, mostradas na Figura 2.21. As amostras foram construídas em dois materiais: ferros fundidos de alto cromo e aço ferramenta AISI D2.

O aparato experimental utilizado foi o mesmo que foi descrito anteriormente por Serantoni e Silva ${ }^{[5,6]}$, variando-se os tempos de aquecimento e

\footnotetext{
${ }^{1}$ A automatização consistiu na implantação de um CLP que interrompia a alimentação elétrica caso houvesse falta de água, de ar comprimido, falha na ventilação, sobrecorrente, temperatura de aquecimento acima da pré-estabelecida ou tempo de aquecimento acima do tempo pré-estabelecido. Além disso, o CLP permitia programar as variáveis de ensaio, tais como temperatura de aquecimento, tempo de aquecimento, tempo de resfriamento e número de ciclos.

${ }^{2}$ Devido à configuração da bobina de aquecimento, a região oposta à região onde o pirômetro óptico realizava a leitura da temperatura era muito mais aquecida. Para assegurar um aquecimento homogêneo de todo o perímetro circunferencial do corpo-de-prova ("pista"), adaptou-se um motor elétrico que permitia que o eixo de suporte do corpo-de-prova girasse a 100 rpm durante o aquecimento.

${ }^{3}$ Passou-se a operar com um pirômetro de radiação infra-vermelha com tempo de resposta 100 vezes mais rápido do que o utilizado anteriormente (de $100 \mathrm{~ms}$ para $1 \mathrm{~ms}$ ).
} 


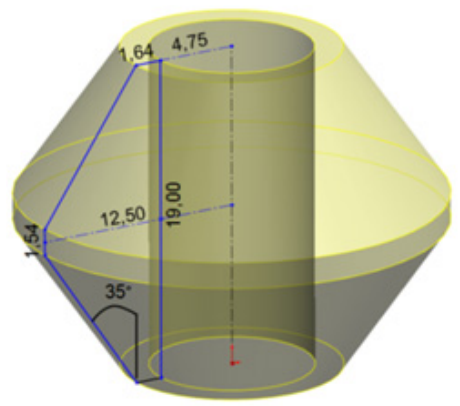

(a)

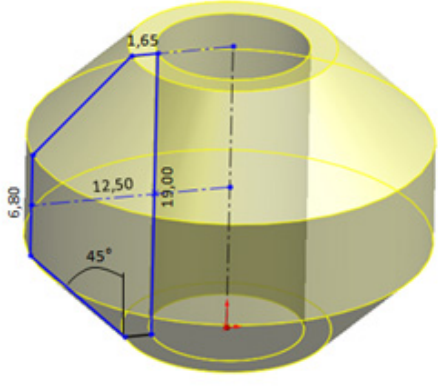

(b)

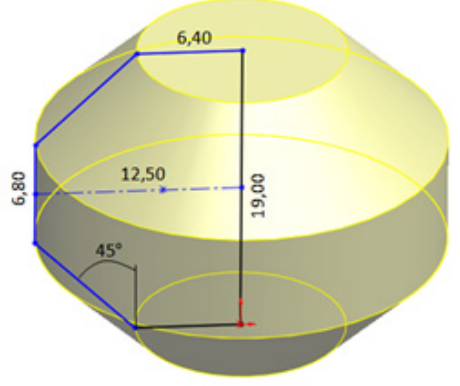

(c)

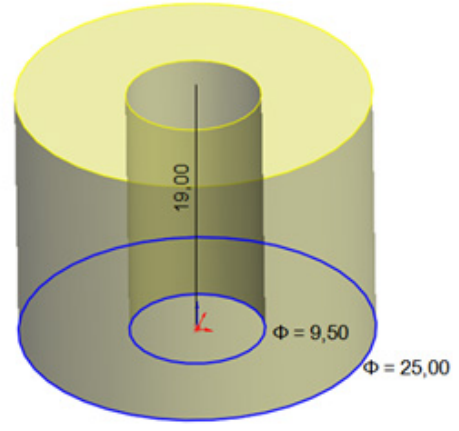

(d)

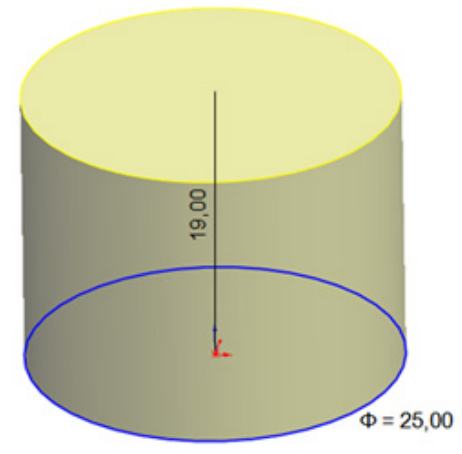

(e)

Figura 2.21: Corpos de prova para ensaio de fadiga térmica utilizados por Matsumoto (medidas em $\mathrm{mm}$ ). ${ }^{[4]]}$

resfriamento, para trabalhar com temperaturas diferentes. Foram utilizados para a análise térmica e análise mecânica o software SOLIDWORKS ${ }^{\circledR}$ para a digitalização da peça e $\operatorname{COSMOS}{ }^{\circledR}$ para a análise por elementos finitos.

Ao final do ensaio de fadiga térmica, os corpos de prova foram submetidos a ensaio por líquido penetrante, com o intuito de revelar a densidade e morfologia das trincas macroscópicas, e à metalografia qualitativa na seção transversal, também para identificar e caracterizar o sítio de nucleação e o caminho de propagação das trincas.

O regime de propagação durante os primeiros 50 ciclos foi controlado por mecanismo de fadiga de baixo ciclo, exibindo as maiores velocidade de propagação das trincas e o regime de propagação depois dos 50 ciclos foram controlados por mecanismos de fadiga de alto ciclo. A nucleação das trincas ocorreu predominantemente pela interface matriz/carboneto e pelo próprio carboneto, sendo a propagação das trincas predominantemente pela interconexão de carbonetos fraturados na superfície do material e predominantemente na interface matriz carboneto em camadas mais profundas do corpo de prova. 


\subsubsection{Tang et al. ${ }^{[57]}$ e Norström et al. ${ }^{[64]}$}

Tang et al. ${ }^{[57]}$ estudaram o efeito da microssegregação de elementos químicos sobre as propriedades mecânicas e o ensaio de fadiga térmica. Foram usados 2 materiais, que são variações de tratamento térmico do aço ferramenta 4CrMoSiV1: Material A: temperado e revenido; Material B: homogeneizado, temperado e revenido. Para eliminar defeitos superficiais, os corpos de prova foram lixados e polidos até se obter uma superfície espelhada. A Figura 2.22 mostra a geometria utilizada nos corpos de prova, que é parte da metodologia de ensaio de fadiga térmica da Uddeholm.
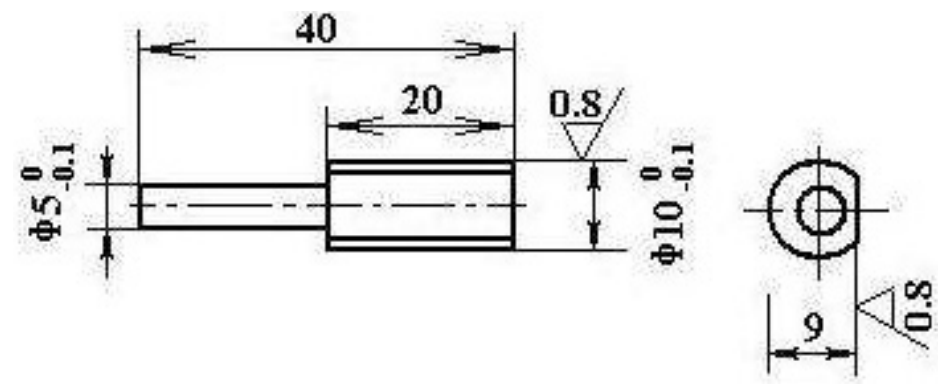

Figura 2.22: Corpos de prova para ensaio de fadiga térmica utilizados por Tang et al. ${ }^{[57]}$

Os testes de fadiga térmica foram feitos segundo normas da Uddeholm Company, com as temperaturas mínima e máxima de 18 e $700{ }^{\circ} \mathrm{C}$, respectivamente. O tempo de aquecimento é de $3,6 \mathrm{~s}$, mantido por mais $1 \mathrm{~s}$. O resfriamento foi feito em água, que resfria o corpo de prova em $8 \mathrm{~s}$, mantendo-se a temperatura por mais $1 \mathrm{~s}$.

O método de ensaio de fadiga térmica desenvolvido pela Uddeholm é descrito de forma breve por Norström et al. ${ }^{[64]}$. O método é baseado no aquecimento indutivo de alta frequência da superfície de uma pequena amostra cilíndrica e sólida de $\oslash 10 \mathrm{~mm} \times 20 \mathrm{~mm}$. O núcleo frio do material serve como uma restrição às deformações térmicas da superfície. O resfriamento pode ser feito tanto por água como por $\operatorname{ar}^{1}$.

Para caracterizar o dano dos corpos de prova, após 3000 ciclos, Tang et al. ${ }^{[57]}$ imergiram-nos em solução de $10 \%$ de ácido clorídrico para eliminar a camada de óxido, e então as trincas de fadiga térmica foram observadas utilizando microscópio óptico.

O dano do material $A$ (não homogeneizado) foi claramente mais severo

${ }^{1}$ Não fica claro no artigo de Norström et al. ${ }^{[64]}$ se o corpo de prova é submerso em água ou se recebe um jato de água. $O$ artigo também não descreve a forma de resfriamento ao ar. 
que o do material B (homogeneizado), uma vez que as trincas finas do material A rapidamente evoluíram para trincas longitudinais profundas. O padrão de trincas formado no material A condiz com a estrutura em bandas formada pela segregação de elementos de liga.

\subsubsection{Howes ${ }^{[48]}$}

Howes $^{[48]}$ apresentou detalhes de sua experiência ganha em ensaios de fadiga térmica feitos com a técnica de leito fluidizado, comparando vantagens e desvantagens em relações aos demais métodos de uso comum. O método permite o ensaio de variadas formas de corpos de prova, inclusive protótipos de componentes reais. Os corpos de prova podem ou não possuir entalhes semelhantes ao ensaio Charpy. As amostras são cicladas entre os leitos de alta e baixa temperatura por meio de cilindros pneumáticos controlados automaticamente, que são sequenciados por temporizadores e interruptores. A Figura 2.23 mostra o aparato experimental com dois leitos fluidizados: um quente $\left(1038^{\circ} \mathrm{C}\right)$ e um frio $\left(43^{\circ} \mathrm{C}\right)$. O ciclo térmico estabelecido foi de aquecimento por $4 \mathrm{~s}$ de $240{ }^{\circ} \mathrm{C}$ até $593{ }^{\circ} \mathrm{C}$ e transferência para o leito frio, para resfriamento por $24 \mathrm{~s}$ até $240{ }^{\circ} \mathrm{C}$ novamente.

Howes traz à discussão um ponto importante: ao passo que uma trinca avança material adentro, a sua ponta fica submetida a uma tensão maior, uma vez que a seção resistente ao esforço diminui. Mas isso é compensado pela menor temperatura da região longe da superfície, o que significa que a resistência mecânica do material é maior naquela região do que mais perto da superfície.

Outro ponto de discussão importante é a comparação entre ensaios de materiais diferentes, que deve sempre compensar o fato de que o ciclo térmico imposto, mesmo que seja igual, não causa os mesmos efeitos em materiais que tenham diferentes condutividades térmicas, calores específicos etc.

As amostras foram caracterizadas apenas com respeito ao tamanho e caminho de propagação das trincas e sua taxa de crescimento. $O$ exame de um grande número de trincas de fadiga térmica mostrou que a maioria é intercristalina e segue caminhos de fragilidades estruturais como dendritas, porosidade, carbonetos e lamelas de grafita. As trincas iniciam em defeitos superficiais e frequentemente mostram evidência de deformação plástica antes que a trinca propague. Muitas trincas originam em pontos onde os contornos de grão interceptam a superfície. 


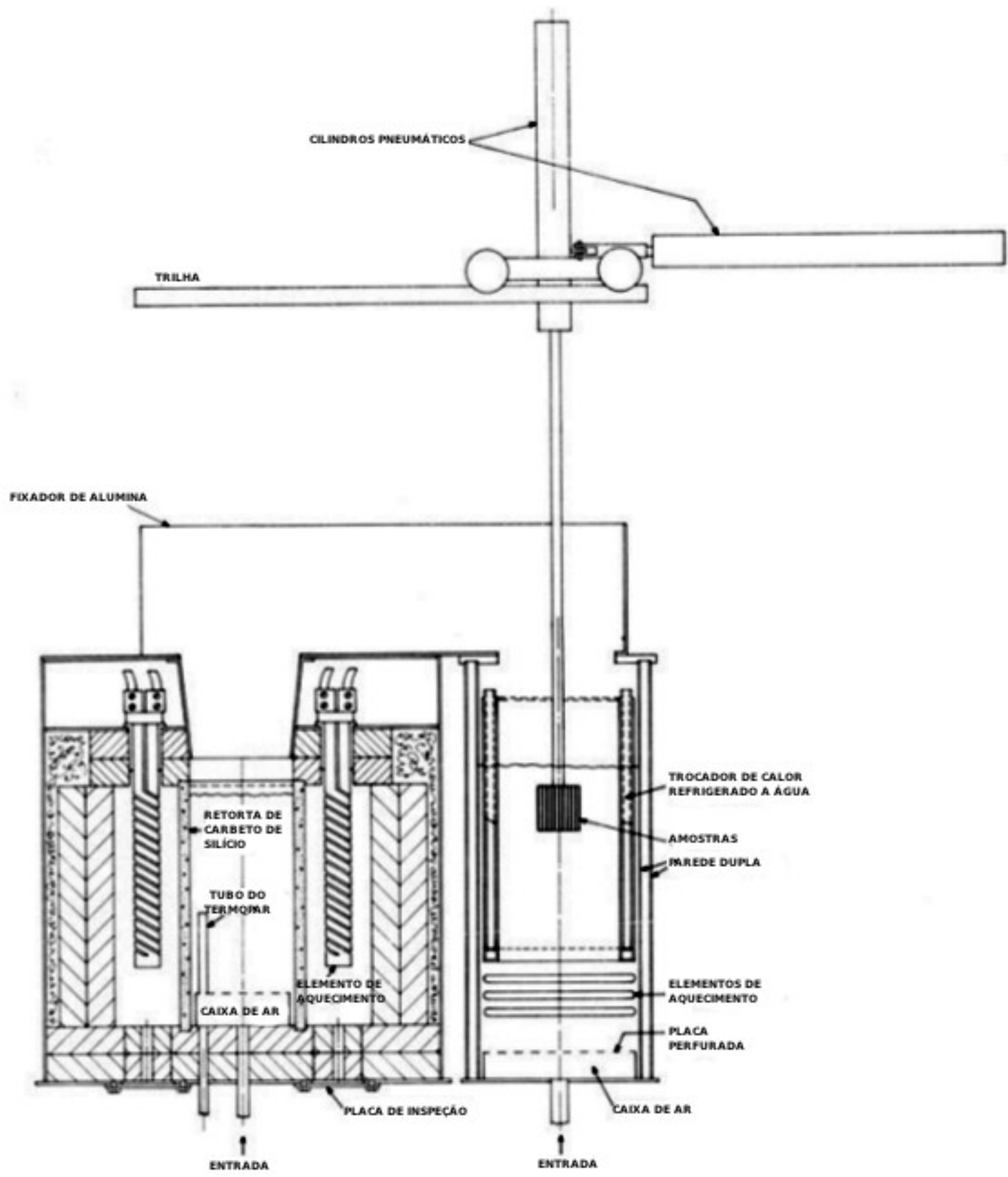

Figura 2.23: Aparato experimental para fadiga térmica em leito fluidizado utilizado por Howes. ${ }^{[48]}$

Howes propôs também um mecanismo de interação entre fadiga térmica e oxidação. Segundo ele, a oxidação em pontos localizados pode reduzir a concentração de elementos de liga e reduzir localmente a resistência do material, formando um sítio para nucleação de trincas. Se a trinca abrir sob tensões de tração e uma quantidade de óxido se formar, a trinca não poderá fechar para a posição inicial e se alargará. Tensões adicionais são impostas à ponta da trinca e acelerar a propagação. 


\subsubsection{Froehlich ${ }^{[65]}$}

Tratamento interessante foi utilizado por Froehlich ${ }^{[65]}$, em seu trabalho de doutorado. Estudando o tratamento superficial duplex de nitretação e deposição de TiN e CrN sobre o aço H13 para aplicação em moldes de injeção de alumínio, um dos ensaios para caracterização do revestimento foi o de fadiga térmica aliado a corrosão e erosão. O comportamento das amostras frente ao banho da liga de alumínio fundida foi avaliado com a imersão das mesmas em um cadinho contendo a liga de alumínio da classe SAE 306 fundida a uma temperatura de $740{ }^{\circ} \mathrm{C}$. A ciclagem térmica era obtida através da imersão e retirada das amostras do banho, que recebiam um jato de ar comprimido ao saírem do banho, conseguindo temperaturas variáveis entre 350 e $600{ }^{\circ} \mathrm{C}$. $\mathrm{O}$ aparato experimental pode ser visto na Figura 2.24.

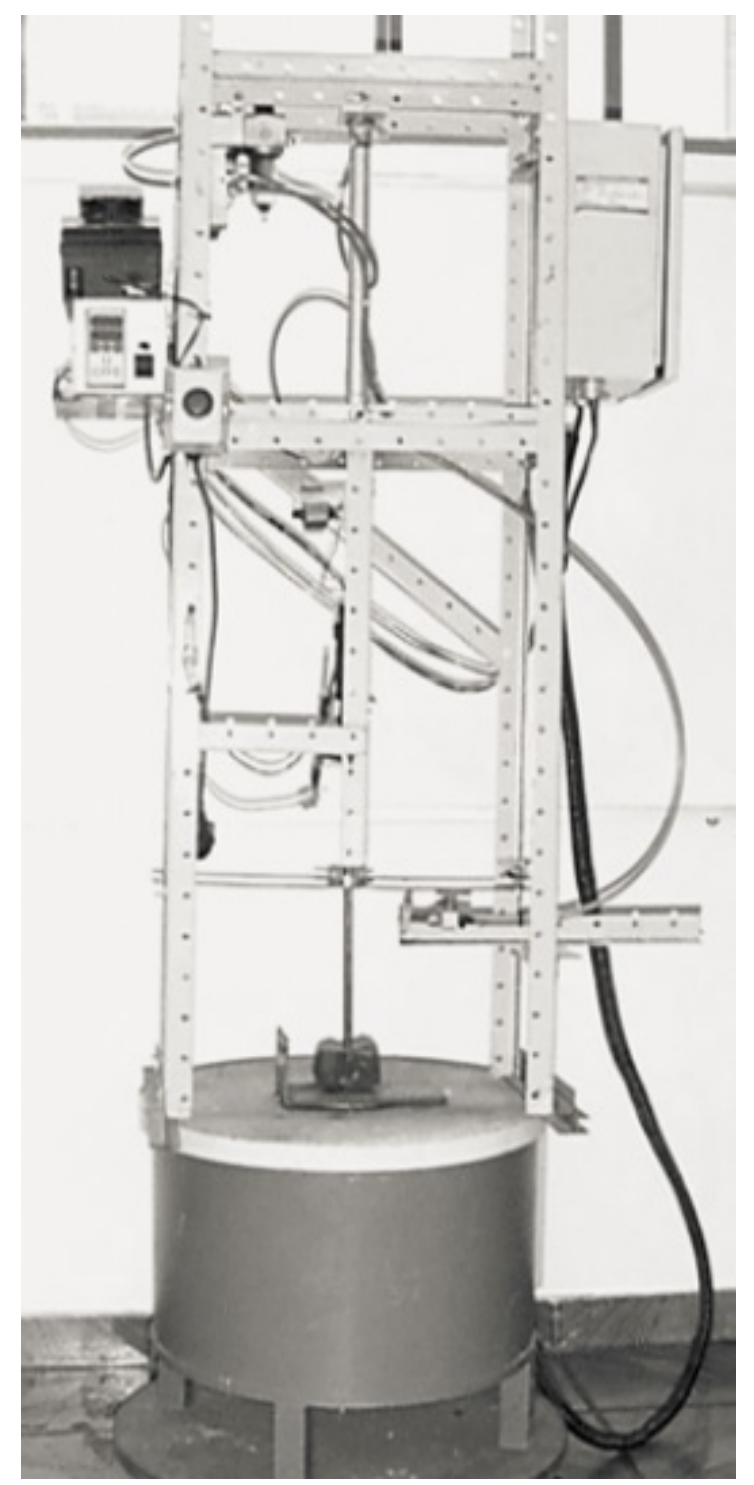

Figura 2.24: Equipamento para avaliação dos efeitos de fadiga térmica, corrosão por alumínio e erosão das amostras de aço H13 estudadas por Froehlich ${ }^{[65]}$. 
Além da movimentação vertical de imersão e retirada, as amostras foram submetidas a rotação, através do acionamento de um motor elétrico acoplado na extremidade do pistão pneumático de movimentação vertical, fazendo com que as amostras transladassem ao redor de um eixo no interior do banho a uma rotação de $180 \mathrm{rpm}$, somando assim aos efeitos de fadiga térmica e ataque químico do aço frente ao alumínio, o efeito da erosão simulando a velocidade de injeção da liga no interior da matriz.

Para avaliação do efeito dos ensaios de fadiga térmica sobre as amostras, foram determinados os seguintes parâmetros: Densidade de trincas $(\rho)$, Profundidade máxima da trinca mais longa $\left(P_{\max }\right)$ e Comprimento médio de trinca $\left(L_{m e d}\right)$. A partir desses parâmetros, Froehlich determinou o chamado "parâmetro de fadiga térmica" $(\delta)$ :

$$
\delta=\frac{\rho \cdot P_{\max } \cdot L_{\text {med }}}{N}
$$

onde $\mathrm{N}$ é o número de ciclos.

Os resultados de dano não podem ser comparados aos demais ensaios de fadiga térmica, uma vez que há múltiplos mecanismos de dano atuando simultaneamente.

\subsubsection{Ott e Diehl ${ }^{[6]}$ e Ferreira ${ }^{[59]}$}

Um arranjo experimental simples - contudo, não muito preciso - foi utilizado por Ott e Diehl ${ }^{[66]}$ e Ferreira ${ }^{[59]}$ para estudar ferros fundidos vermiculares e o aço ferramenta $\mathrm{H} 13$ nitretado, respectivamente. O objetivo de Ferreira foi simular as solicitações térmicas sofridas pelos moldes de injeção de alumínio.

Os corpos de prova são discos metálicos, temperados e revenidos, com superfície polida em retífica e usinagem de 2 rebaixos circulares, conforme mostra a Figura 2.25. As amostras para ensaio de fadiga térmica foram dispostas em aparato próprio (Figura 2.26) sugerido por Ott ${ }^{[6]}$. No aparato, o corpo de prova é sustentado verticalmente e é aquecido, por um lado, por uma chama proveniente da queima de GLP e resfriado, pelo outro lado, por um jato d'água intermitente. As temperaturas eram medidas por um termopar tipo $\mathrm{K}$ na superfície fria e a ciclagem térmica era feita entre 50 e $500^{\circ} \mathrm{C}$. O critério de parada do experimento era o surgimento de uma trinca visível que fosse de um rebaixo circular até o outro, ao lado. As amostras não foram analisadas metalograficamente após os ensaios. 


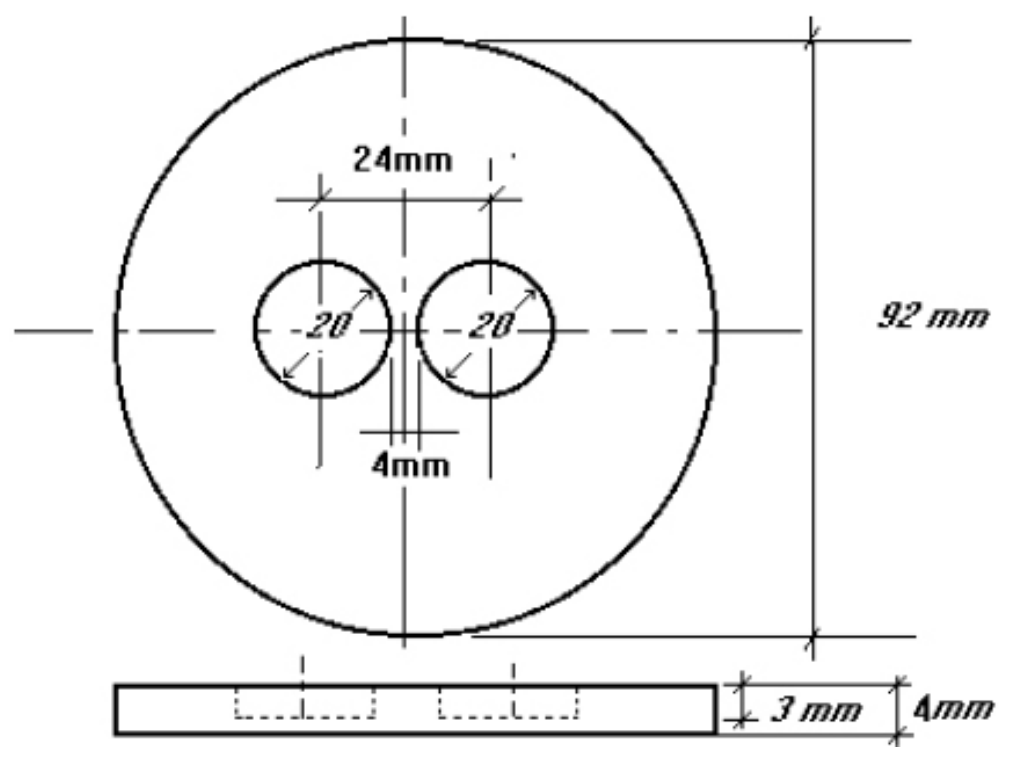

Figura 2.25: Dimensões do corpo de prova para ensaio de fadiga térmica utilizado por Ott e Diehl ${ }^{[66]}$ e Ferreira ${ }^{[59]}$.

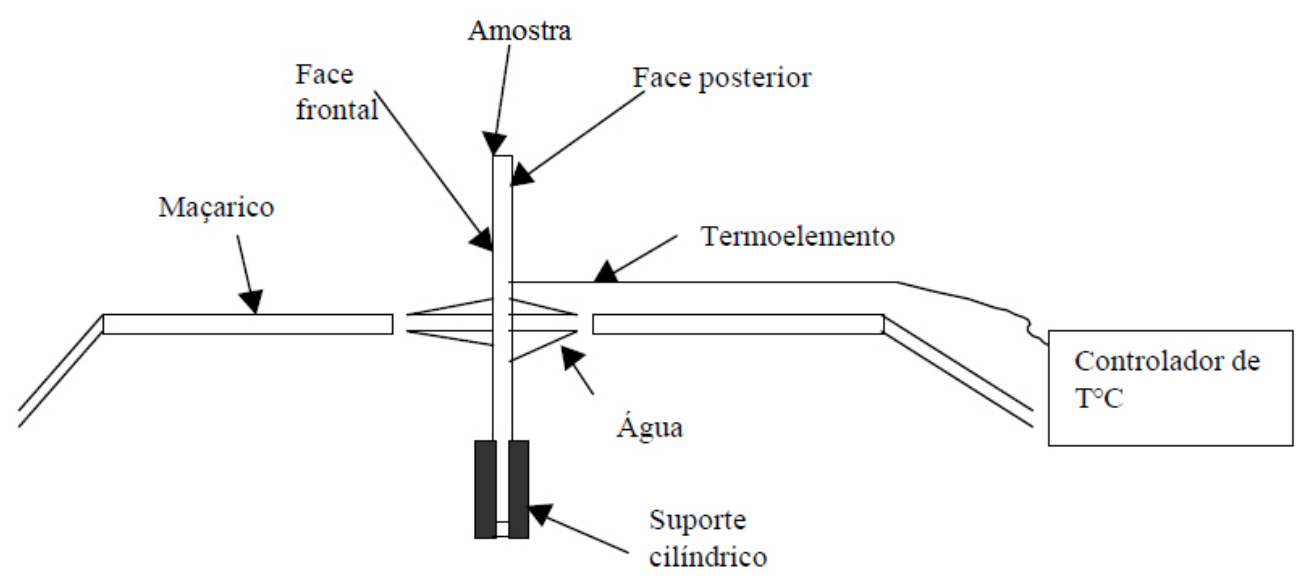

(a)

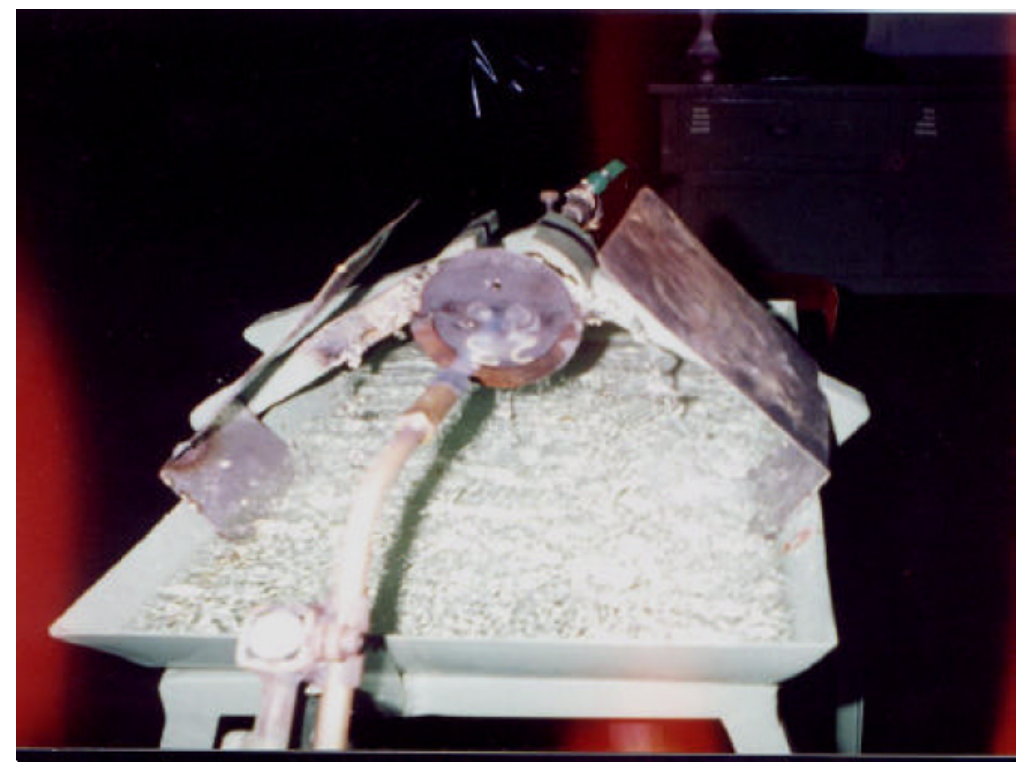

(b)

Figura 2.26: Aparato experimental desenvolvido por Ott e Diehl ${ }^{[66]}$ e utilizado por Ferreira ${ }^{[59]}$. (a) Esquema representativo; (b) Fotografia do equipamento. 
As formas utilizadas para aquecimento e resfriamento do corpo de prova introduzem formas de aceleração de dano que podem mascarar os efeitos de fadiga térmica: o aquecimento por chama com gás metano pode gerar reações do metal com $\mathrm{CO}$ ou $\mathrm{C}$, produtos de combustão incompleta do metano e o oxigênio misturado ao gás pode oxidar o metal além do que ele oxidaria ao ar; do outro lado do corpo de prova, o resfriamento com jato de água acelera a corrosão metálica.

Além disso, é questionável se as formas de aplicação de aquecimento e resfriamento geram fadiga térmica, pois um dos lados do corpo de prova é submetido à alta temperatura constante, enquanto é o outro lado do corpo de prova que recebe jatos intermitentes de água pare refrigeração. $O$ aquecimento constante do lado exposto à chama pode causar crescimento de grão, coalescimento e arredondamento de precipitados e todos os outros mecanismos de transformação em alta temperatura. 
3 Materiais e Métodos 



\subsection{Plano de trabalho}

\subsubsection{Objetivo}

Foi dito no capítulo anterior que este trabalho está inserido no Projeto IPT Sistema avançado para projeto de ligas aplicadas em ferramentas de conformação a quente ${ }^{[30]}$. No Projeto conduzido por EPUSP e IPT, que alia modelamento computacional a ensaios em escala laboratorial e piloto, foram estudadas duas ligas: o aço ferramenta $\mathrm{H} 13$ e o aço ferramenta C99, semelhante ao aço que foi previamente estudado por Silva ${ }^{[6]}$, que é um aço do tipo aço matriz $+N b C$ (Seção 2.2.2). O ensaio de fadiga térmica foi realizado para validar os modelos de fadiga térmica na simulação dos corpos de prova e das ferramentas. Não foi estudada a fadiga térmica do aço H13, porém entende-se que os mecanismos que atuem na matriz do aço C99 sejam os mesmos que no $\mathrm{H} 13$.

Entretanto, o objetivo deste trabalho tem abordagem diferente do projeto para ir ao encontro de investigar e entender os mecanismos de nucleação de trincas de fadiga térmica e da formação da malha de trincas na superfície. Para isso, foi necessário olhar em maiores detalhes para as características da superfície durante os primeiros estágios da formação das trincas e para a microestrutura próxima à superfície.

A hipótese que se deseja confirmar é a de que a oxidação favorece a fragilização da superfície em condições não homogêneas na microestrutura que, submetida a tensões cíclicas causadas pelas variações do gradiente de temperaturas, sofre fratura proporcional às tensões características do carregamento e propriedades mecânicas do material.

\subsubsection{Planejamento}

Para comprovar a hipótese anterior, os seguintes experimentos e análises foram propostos:

1. Ensaios de oxidação estática

(a) Levantamento das curvas de oxidação

(b) Comparação da oxidação em quatro temperaturas

(c) Caracterização dos óxidos formados na superfície

(d) Identificação da morfologia da interface metal/óxido 
2. Cálculo de tensões superficiais ao final do aquecimento e do resfriamento;

3. Ensaio de fadiga térmica em uma condição de referência;

4. Ensaios de fadiga térmica com variação de um dos parâmetros de cada vez em relação à condição de referência:

(a) Temperatura máxima (maior);

Espera-se que, em temperatura maior, a oxidação seja maior. O gradiente térmico e, consequentemente, a tensão de compressão na superfície, serão maiores. Logo, espera-se que a falha ocorra antes da condição de referência.

(b) Velocidade de aquecimento (menor);

Espera-se que, com aquecimento mais lento, o material passe mais tempo em alta temperatura, aumentando a oxidação. Entretanto, o gradiente térmico é menor. $\mathrm{O}$ tempo de vida deve ser verificado.

(c) Capacidade oxidante da atmosfera (menor);

Um ensaio em atmosfera menos oxidante, na presença de argônio e baixa concentração de oxigênio, deverá permitir um ensaio em que ocorra apenas ciclagem térmica, sem a fragilização da superfície devido à formação de óxidos. Espera-se observar se as tensões térmicas são suficientes para fraturar os corpos de prova. Manson e Halford ${ }^{[67]}$ concluíram que, em ambiente oxidante, a vida em fadiga é $10 \%$ menor que em ambiente não-oxidante.

(d) Dureza (menor).

Após obter microestrutura super-revenida, espera-se verificar se a densidade de trincas é influenciada pela dureza da matriz ou por tamanho de grão, uma vez que as trincas são frequentemente associadas a contornos de grão austeníticos. Adicionalmente, desejase verificar se há influência da variação de dureza e tenacidade no tempo de vida do material.

Foi realizada uma seleção entre os métodos de ensaio apresentados na Seção 2.5.2, com base nos seguintes critérios (sem ordem de prioridades):

- Tempo de análise;

- Custo; 
- Dados de saída / resultados obtidos;

- Complexidade dos corpos de prova;

- Viabilidade/compatibilidade técnica com equipamentos já disponíveis no IPT;

- Aplicação dos resultados obtidos nas ferramentas de conformação a quente estudadas no Projeto do IPT;

- Facilidade de modelamento e simulação computacional.

Tendo em vista que:

- O ensaio deve buscar reproduzir ciclos térmicos sofridos por ferramentas de conformação a quente, embora possam ser diferentes em termos de temperaturas alcançadas e velocidades de aquecimento;

- O ensaio deve simular apenas as solicitações térmicas aos materiais das ferramentas para conformação a quente, eliminando os fenômenos mecânicos, erosivos, abrasivos etc. ;

- As condições para modificações das características físico-químicas superficiais inerentes aos processos de conformação a quente, como oxidação e desplacamento, devem ser conservadas;

- O IPT já possuía experiência em ensaios de fadiga térmica utilizando aquecimento indutivo e resfriamento por imersão em água, pelo método utilizado por Serantoni, Silva e Matsumoto ${ }^{[5,6,47]}$;

- O ensaio deveria alimentar e validar o modelamento realizado pela equipe da EPUSP;

- Nem todos os métodos de ensaio registrados na literatura produzem resultados de forma confiável, reprodutível e prática, para correta explicação dos fenômenos envolvidos,

optou-se por utilizar uma reprodução do método experimental utilizado por Medjedoub e Rézaï-Aria. ${ }^{[3,49]}$ para confirmar as suas conclusões sobre os efeitos da temperatura máxima do ciclo e do tempo de aquecimento em um aço com carbonetos NbC primários e observar com maior atenção os fenômenos de nucleação das trincas. 


\subsection{Materiais}

\subsubsection{Seleção do material}

O material utilizado para confecção dos corpos de prova de fadiga térmica é o aço ferramenta fundido com carbonetos de nióbio desenvolvido no IPT, chamado C99. O desenvolvimento do C99 foi baseado no conceito "aço matriz + NbC", com adição 3,5\% de nióbio e carbono em proporções estequiométricas sobre uma liga Fe-W-Cr-Mo-V-C. Informações sobre esse aço foram dadas na Seção 2.2.2.

Pela experiência de fundição do C99 no IPT, esse material não apresenta boas características internas se fundido em moldes de areia. A presença de porosidades e inclusões, quando fundido em areia, torna o material impróprio para uso em fadiga mecânica e/ou térmica. Entretanto, os tarugos fundidos em coquilha têm apresentado bons resultados de integridade interna e superficial, o que motivou sua escolha como matéria-prima para obtenção dos corpos de prova para o ensaio de fadiga térmica.

Para selecionar o tratamento térmico que confere a melhor combinação de dureza e tenacidade ao material, foi construída uma curva de revenimento, que é mostrada na Figura 3.1:

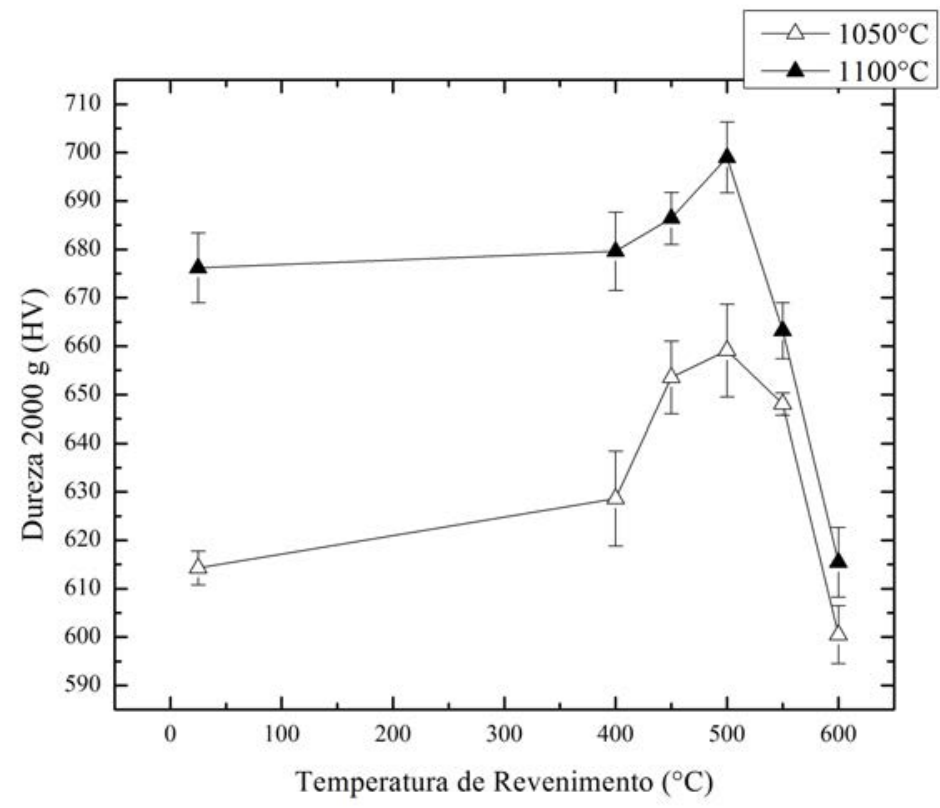

Figura 3.1: Curva de revenimento - Medidas de dureza Vickers com carga de $2 \mathrm{~kg}$ obtidas após tratamentos térmicos de austenitização a $1050 \mathrm{e}$ $1100^{\circ} \mathrm{C}$ e revenimentos em temperaturas entre 450 e $600^{\circ} \mathrm{C}$. O pico de dureza secundária no revenimento foi atingido com tratamento a $500^{\circ} \mathrm{C}$. 
A partir desses valores, então, selecionou-se o tratamento térmico de austenitização a $1050{ }^{\circ} \mathrm{C}$, por 2 horas, em ambiente não oxidante (vácuo ou argônio), com resfriamento ao ar calmo, e duplo revenimento a $500{ }^{\circ} \mathrm{C}$, por 2 horas, com resfriamento ao ar. O intervalo de tempo entre os revenimentos é apenas o suficiente para que o material atinja a temperatura ambiente. A Figura $\mathbf{3 . 2}$ mostra a microestrutura da liga C99 após o tratamento térmico selecionado, composta de martensita revenida, carbonetos primários $\mathrm{NbC}$ poligonais e carbonetos secundários precipitados durante o revenimento.

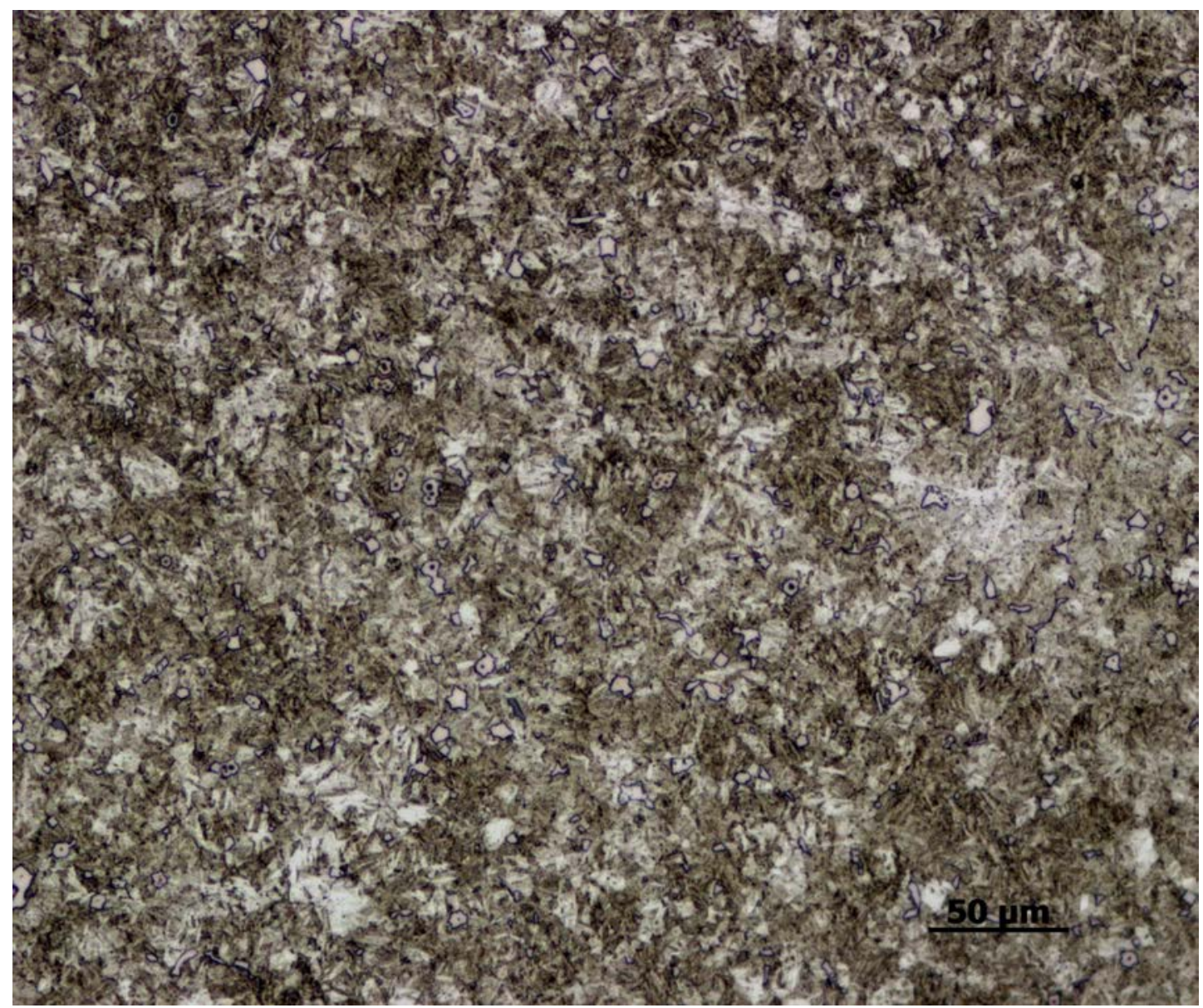

Figura 3.2: Microestrutura da liga C99 após tratamento térmico. Matriz de martensita revenida, com carbonetos primários $\mathrm{NbC}$ poligonais de tamanho entre 5 a $10 \mu \mathrm{m}$. No centro de alguns carbonetos, de cor branca, é possível ver o núcleo de carboneto de titânio com coloração cinza.

\subsubsection{Confecção dos corpos de prova}

Os corpos de prova foram usinados a partir de tarugos fundidos no IPT. A carga para fundição foi calculada a partir de sucata de aço carbono e ferroligas e fundida em forno de indução, com capacidade de carga de $130 \mathrm{~kg}$, em refratário de $\mathrm{MgO}$ e proteção de argônio sobre o banho. O aquecimento do metal líquido foi feito até $1700{ }^{\circ} \mathrm{C}$ e mantido por 5 minutos. O titânio foi 
adicionado encapsulado em tubo de aço, 5 minutos antes do vazamento, para evitar perdas. O vazamento foi feito a $1660 \pm 10{ }^{\circ} \mathrm{C}$.

A composição química dos dois tarugos utilizados na confecção dos corpos de prova é mostrada na Tabela 3.1. Os tarugos têm diâmetro de $150 \mathrm{~mm}$ e comprimento útil de $600 \mathrm{~mm}$ (Figura 3.3). A partir dos tarugos, foram retiradas fatias de aproximadamente $85 \mathrm{~mm}$ de espessura e, então, foram cortados pinos, por eletroerosão, de regiões equidistantes do centro, a fim de evitar regiões com diferenças de microestrutura e composição química.

Tabela 3.1: Resultados das análises químicas das corridas de C99.

\begin{tabular}{c|ccccccccc}
\hline Corrida / & \multicolumn{10}{c}{ Composição (\% massa) } \\
Data & $\mathrm{C}$ & $\mathrm{Cr}$ & $\mathrm{Mn}$ & $\mathrm{Mo}$ & $\mathrm{Nb}$ & $\mathrm{Ti}$ & $\mathrm{Si}$ & $\mathrm{V}$ & $\mathrm{W}$ \\
\hline $9-04 / 11 / 2014$ & 0,85 & 3,04 & 0,61 & 1,75 & 3,11 & 0,32 & 0,42 & 1,1 & 1,22 \\
$11-07 / 11 / 2014$ & 0,83 & 2,94 & 0,48 & 1,66 & 3,07 & 0,21 & 0,26 & 1,08 & 1,19 \\
\hline
\end{tabular}

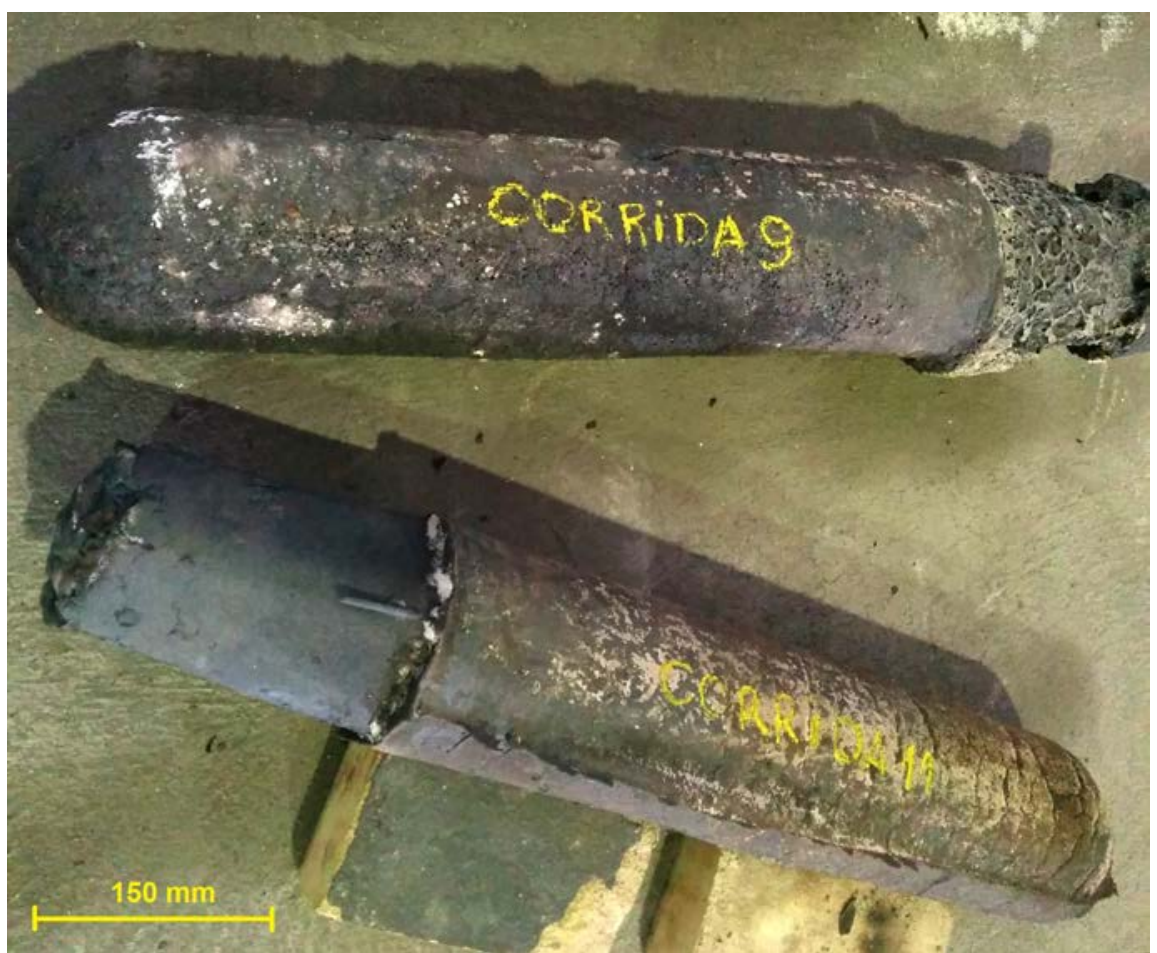

Figura 3.3: Tarugos fundidos nas corridas 9 e 11, para produção de corpos de prova de fadiga térmica. Os tarugos têm diâmetro de $150 \mathrm{~mm}$ e comprimento útil de $600 \mathrm{~mm}$.

Para os ensaios de oxidação estática, a partir de um dos pinos cortados por eletroerosão a partir do tarugo, foram cortadas amostras de $\oslash 30 \mathrm{~mm}$ e espessura de $3,5 \mathrm{~mm}$ (em forma de moedas). Uma das faces da amostra foi lixada e polida até pasta de diamante de $1 \mu \mathrm{m}$, para observação da superfície após oxidação. Foram preparadas 16 amostras idênticas.

Como foi dito, para o ensaio de fadiga térmica, buscou-se reproduzir as 
condições do experimento de Medjedoub ${ }^{[3]}$. Portanto, o desenho de corpo de prova que foi utilizado neste trabalho é igual ao que mostra a Figura 3.4.

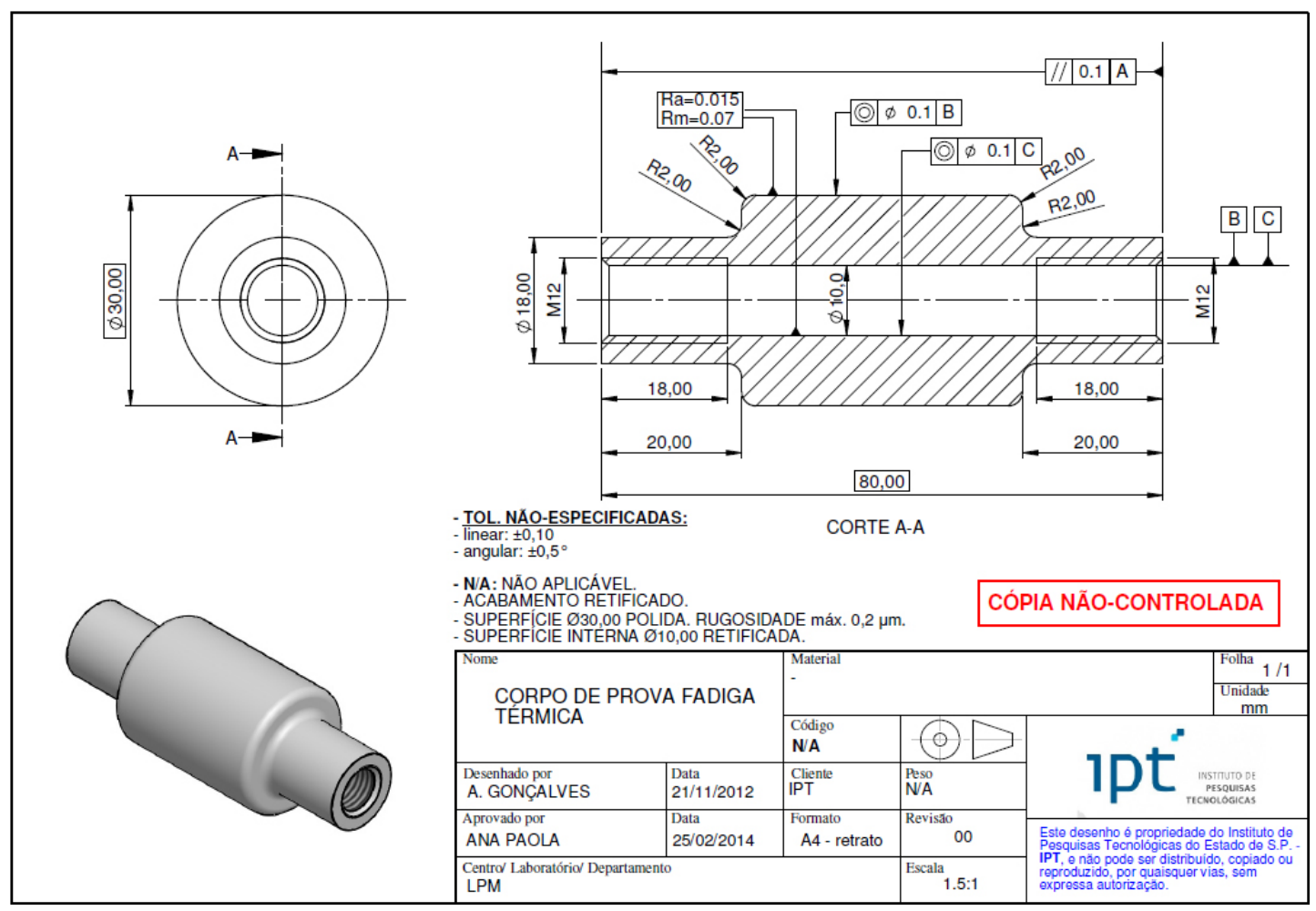

Figura 3.4: Desenho do corpo de prova de fadiga térmica, semelhante ao criado por Medjedoub ${ }^{[3]}$. O comprimento total é de $80 \mathrm{~mm}$, sendo $40 \mathrm{~mm}$ na zona central de aquecimento e pescoços de $20 \mathrm{~mm}$ de comprimento. $O$ diâmetro na zona central é de $30 \mathrm{~mm}$ e dos pescoços é de $18 \mathrm{~mm}$. O furo central possui diâmetro de $10 \mathrm{~mm}$, com roscas M12 nas duas pontas, para fixação do corpo de prova nas mangueiras de água. O acabamento da superfície utilizado foi de 0,2 $\mu \mathrm{m}$.

Os corpos de prova foram usinados após recozimento e tratados já na forma final. O acabamento após tratamento térmico foi feito com retífica e polimento com pasta de diamante de $3 \mu \mathrm{m}$. O acabamento interno do furo foi realizado por brunimento. Para a tomada de temperaturas em perfil radial, foram confeccionados corpos de prova com furos de $\oslash 1,5 \mathrm{~mm} \times 15 \mathrm{~mm}$ localizados em diferentes profundidades em relação à superfície, nas regiões mostradas na Figura 3.5. No total, foram produzidos 60 corpos de prova no formato padrão e 5 corpos de prova para instrumentação, que foram utilizados também para os ajustes e testes preliminares. 

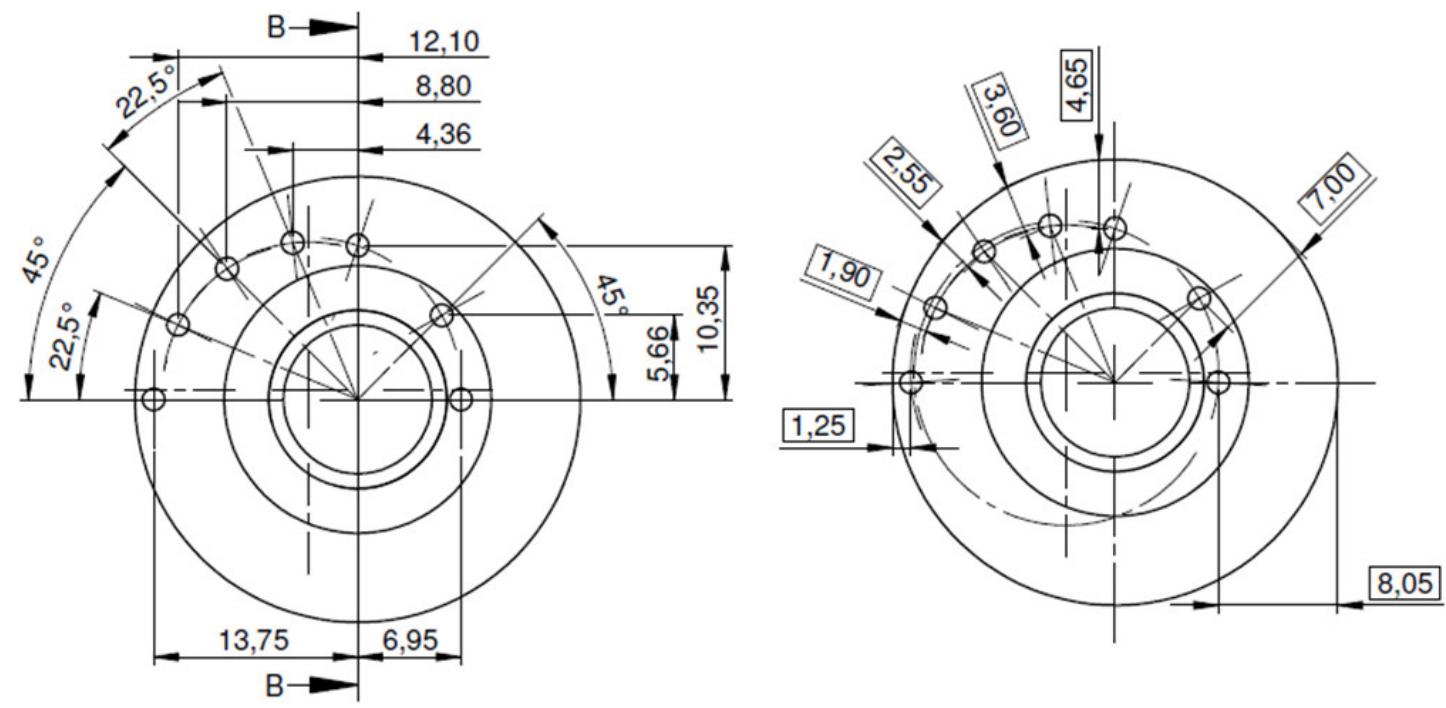

Figura 3.5: Desenho do corpo de prova com furos para ensaio de fadiga térmica instrumentado. As dimensões externas são as mesmas do corpo de prova padrão. Os furos foram feitos no sentido longitudinal, com profundidades de 1,25, 1,90, 2,55, 3,60, 4,65 e 7,00 mm. O furo com profundidade $8,05 \mathrm{~mm}$ não foi utilizado. 


\subsection{Métodos}

Para realização dos experimentos propostos no Plano de Trabalho (Seção 3.1), utilizou-se a seguinte metodologia:

\subsubsection{Ensaios de oxidação estática}

Para observar exclusivamente o fenômeno de oxidação, sem aplicação de gradiente térmico ou ciclos de aquecimento, as 16 amostras foram separadas em 4 grupos de ensaio. Nos ensaios, 4 amostras foram colocadas ao mesmo tempo em um forno mufla aquecido com a face polida voltada para cima e retiradas uma por vez, em tempos determinados: $30 \mathrm{~min}, 60 \mathrm{~min}, 120 \mathrm{~min}$ e $240 \mathrm{~min}$. Os grupos foram ensaiados a $500^{\circ} \mathrm{C}, 550^{\circ} \mathrm{C}, 600^{\circ} \mathrm{C}$ e $650^{\circ} \mathrm{C}$. O resfriamento foi feito ao ar calmo.

As amostras foram levadas ao microscópio eletrônico de varredura FEI Quanta 3D do IPT, equipado com feixe de íons de gálio (FIB), que possibilita remoção de material durante a análise de feixe de elétrons (MEV-FEG). Depois do corte com FIB, as camadas de óxido foram medidas para levantamento das curvas de oxidação e as amostras foram cortadas para observação da seção transversal em microscópio óptico.

Os 4 grupos de 4 amostras foram preparados por FIB para observação e medição da camada oxidada. A Figura 3.6 mostra as etapas de análise da camada de óxido para medição da sua espessura.

\subsubsection{Equipamento dos ensaios de fadiga térmica}

O equipamento construído para o ensaio de fadiga térmica (Figura 3.7) utiliza um forno de aquecimento indutivo da marca Jamo, modelo JMMF, com potência máxima de $25 \mathrm{~kW}$ e frequência de saída de $220 \mathrm{kHz}$. O comando do forno (Figura 3.8) é feito por um controlador PID (marca Novus, modelo N1200), que recebe sinal do pirômetro óptico (marca LumaSense, modelo IGA $323 / L O$ ) apontado para o centro do corpo de prova, e que mede temperaturas entre 100 e $700^{\circ} \mathrm{C}$, com um tempo de resposta de $30 \mathrm{~ms}$. 


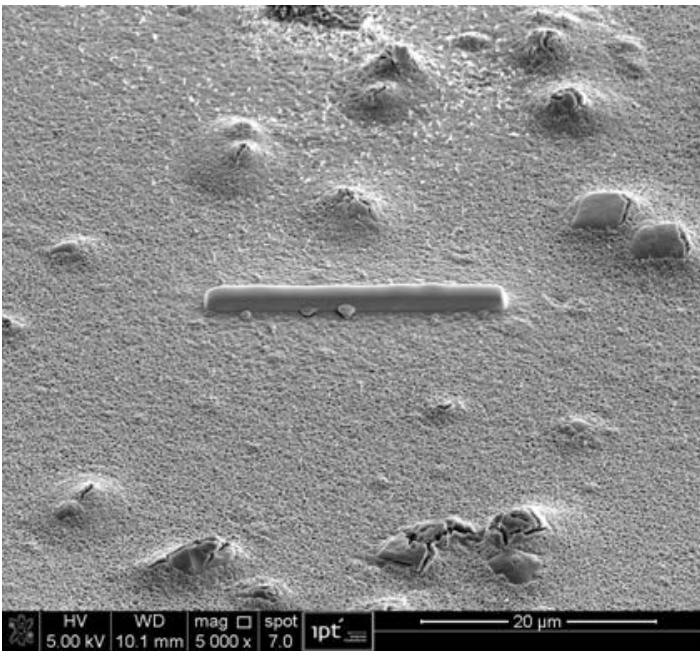

(a)

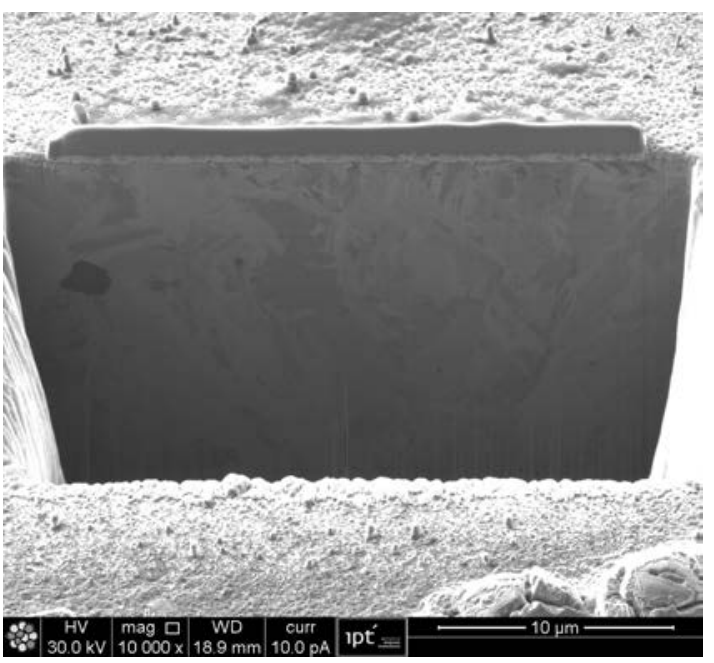

(c)

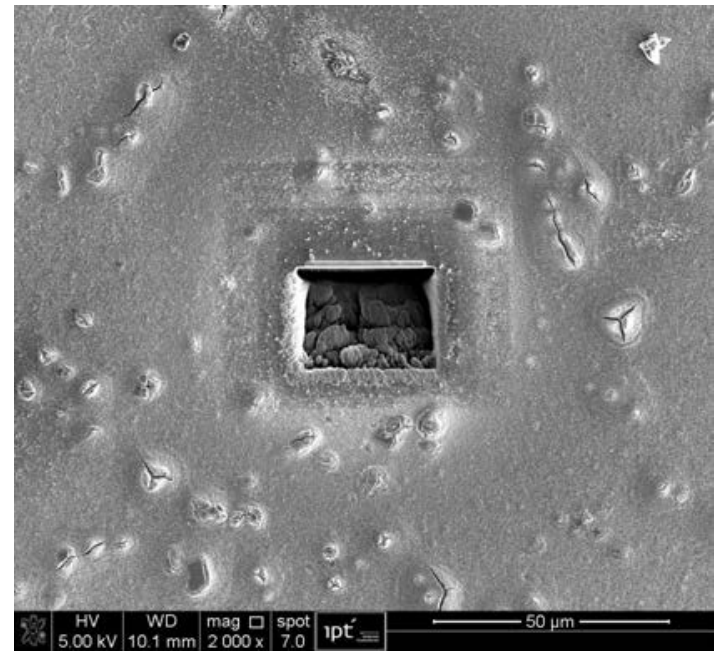

(b)

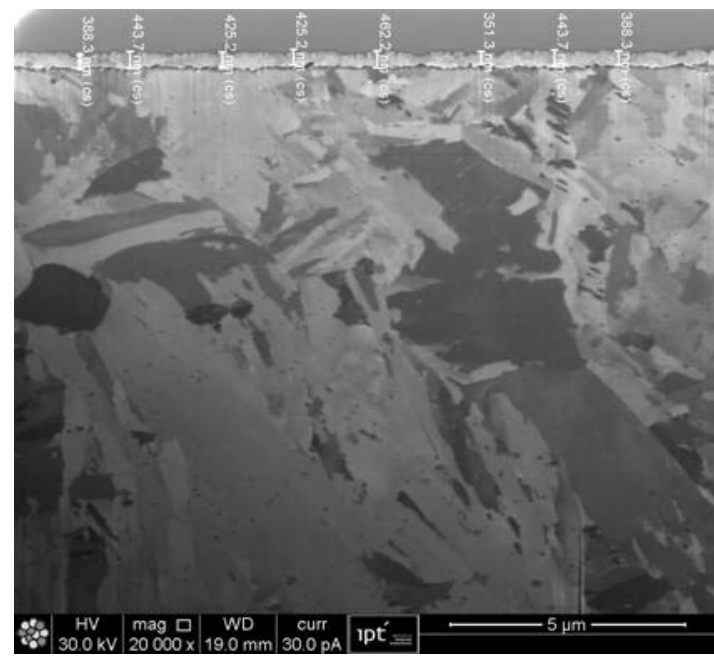

(d)

Figura 3.6: Etapas de preparação por FIB da superfície e seção transversal das amostras oxidadas para medição da camada de óxido. (a) Deposição de platina para proteção da região a ser cortada; (b) Remoção de material na região demarcada para revelação da seção transversal; (c) Alisamento da superfície (polimento) da seção transversal; (d) Medição da camada de óxido identificada na superfície. 


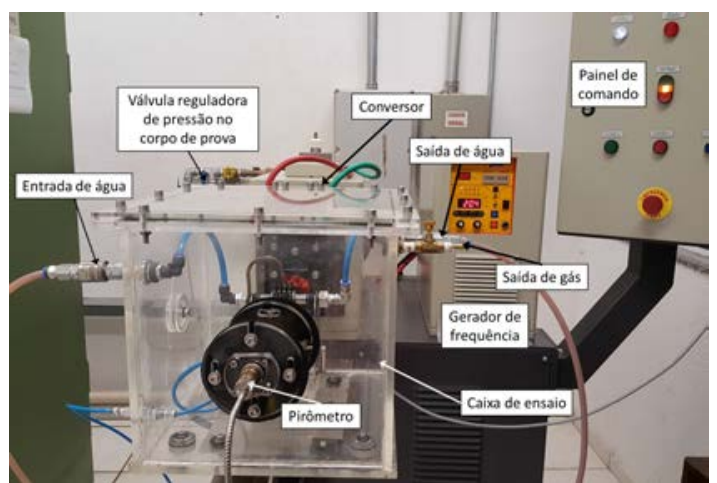

(a)

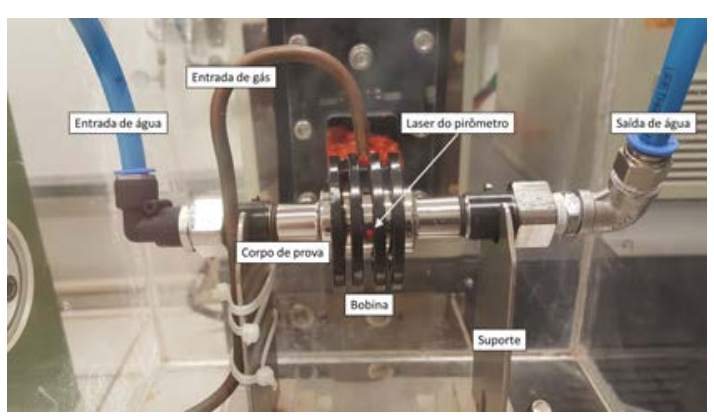

(b)

Figura 3.7: Montagem experimental para ensaio de fadiga térmica. (a) Visão geral do equipamento, com montagem da caixa de ensaio acoplada ao forno de indução; (b) Detalhes da caixa de ensaio, com montagem do CP dentro da bobina, conectado à entrada e saída de água, com entrada de gás e laser do pirômetro indicando local da medida.

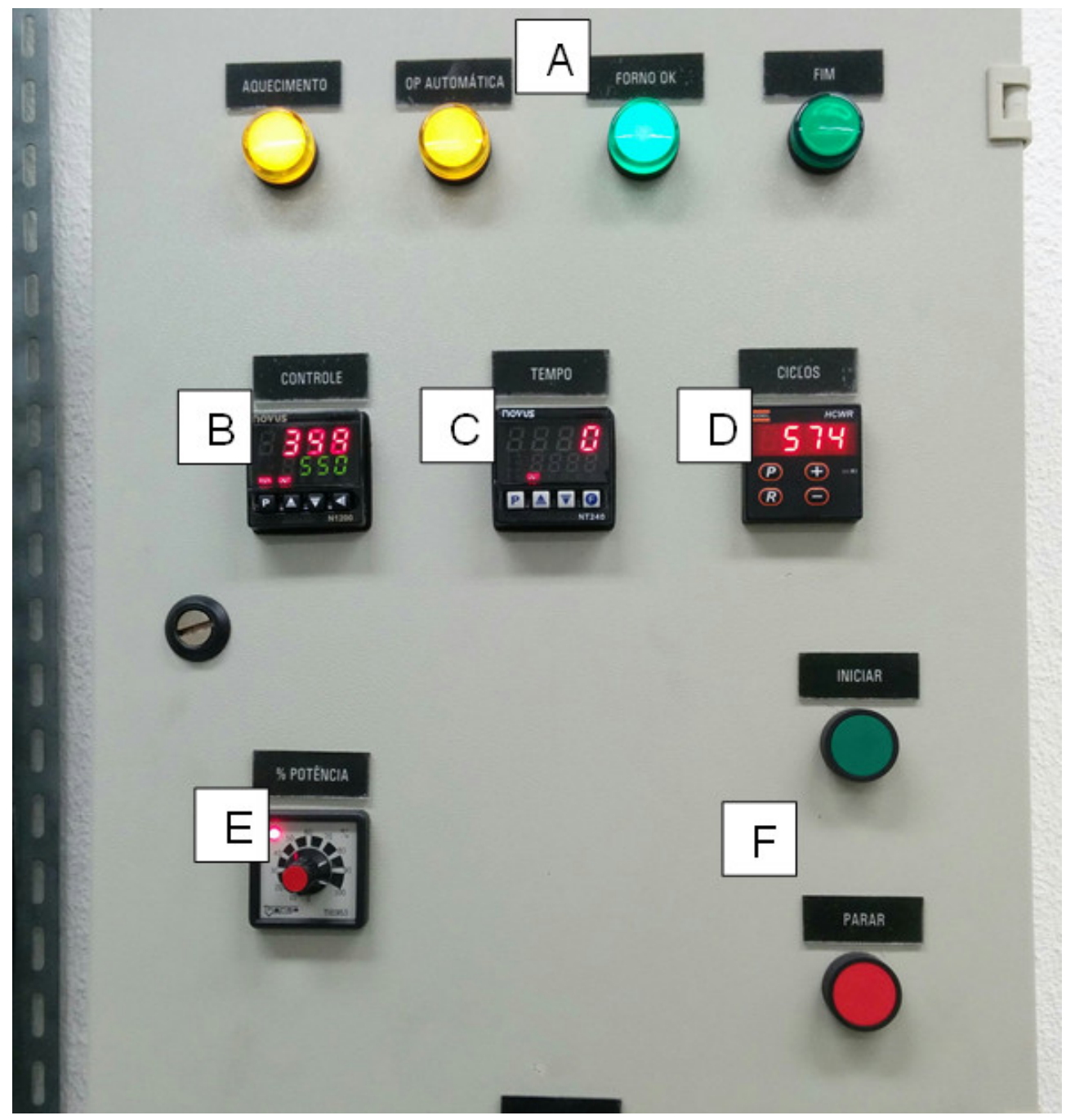

Figura 3.8: Painel de controle para ensaio de fadiga térmica. A: Luzes indicativas de aquecimento, operação automática, situação do forno e fim do ensaio; B: Controlador dos ciclos de temperatura medidos pelo pirômetro; C: Contador de tempo de ciclo; D: Programador e contador do número de ciclos; $\mathrm{E}$ : Regulador de potência de aquecimento; F: Botões de iniciar/parar ensaio. 
Deve-se ressaltar que, na época de realização de alguns ensaios preliminares, o forno de indução, a bobina e a montagem experimental eram diferentes da configuração utilizada nos ensaios definitivos. Na sua primeira versão, o forno tinha frequência de saída de $52 \mathrm{kHz}$, a bobina tinha outras geometrias, menos homogêneas, e a montagem não utilizava a caixa de ensaio em acrílico ${ }^{1}$. A Figura 3.9 mostra as três versões de bobina utilizadas nos ensaios.

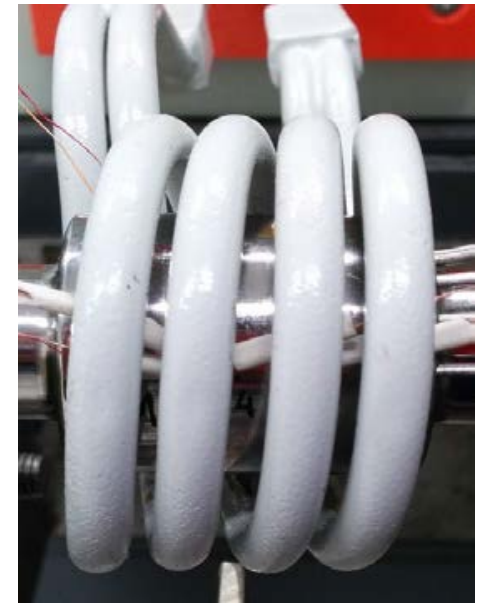

(a)

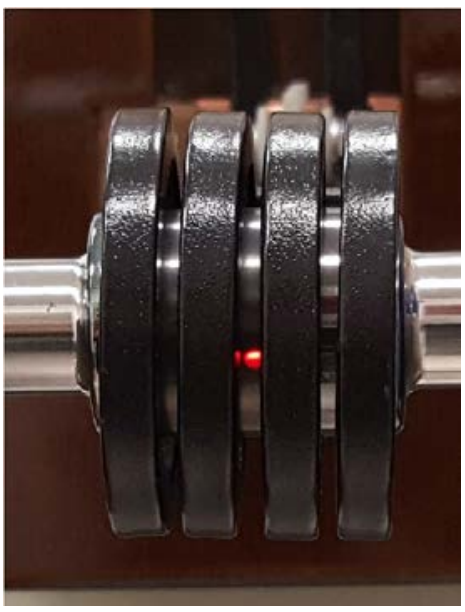

(b)

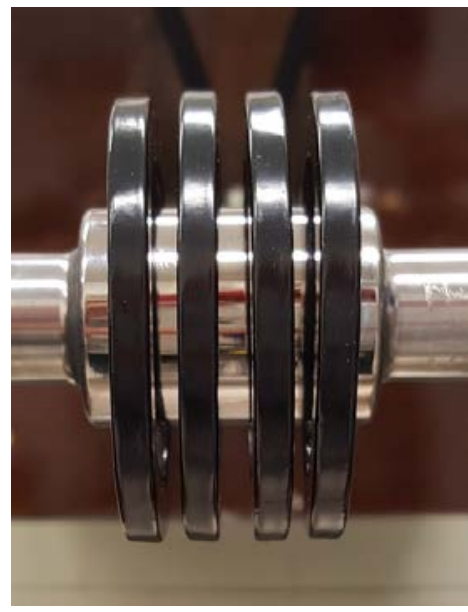

(c)

Figura 3.9: Três versões de bobina de indução utilizadas nos ensaios. (a)

Bobina 1, com tubo redondo e enrolamento inclinado e aquecimento não-homogêneo; (b) Bobina 2, com tubo quadrado e enrolamento reto; (c)

Bobina 3 (última versão), com tubo retangular e enrolamento reto.

A última versão da bobina, utilizada nos ensaios, foi projetada utilizando o software de simulação de aquecimento indutivo 2DELTA - ElectroThermal Analysis, em 2 dimensões. A bobina foi construída com enrolamento de 4 voltas de tubo de cobre de seção retangular $5 \times 7 \mathrm{~mm}$, com diâmetro interno de $44 \mathrm{~mm}$ (deixando um espaço de $7 \mathrm{~mm}$ entre o corpo de prova e a bobina), coberta com pintura eletrostática a pó. As espiras centrais estão espaçadas $4 \mathrm{~mm}$, enquanto os espaçamentos das laterais são de $3 \mathrm{~mm}$. A distribuição de temperaturas calculada pela simulação é mostrada na Figura 3.10. Na simulação, foi utilizado um aquecimento até $T=550^{\circ} \mathrm{C}$, por $t=1,2 \mathrm{~s}$. Na superfície $(p=0,00 \mathrm{~mm})$, a temperatura é aproximadamente constante nos $12 \mathrm{~mm}$ centrais, diminuindo em direção às laterais.

A caixa de ensaio foi projetada e construída com placas de acrílico de $12 \mathrm{~mm}$ de espessura, coladas e vedadas com cola 100\% acrílica de ultrarresistência. A vedação na região de engate da bobina foi feita com adesivo de silicone para altas temperaturas, e a vedação da tampa foi feita com o-ring

${ }^{1} \mathrm{~A}$ forma da montagem não interfere nos resultados, uma vez que afeta apenas a forma de fixação dos corpos de prova, externa ao experimento. 


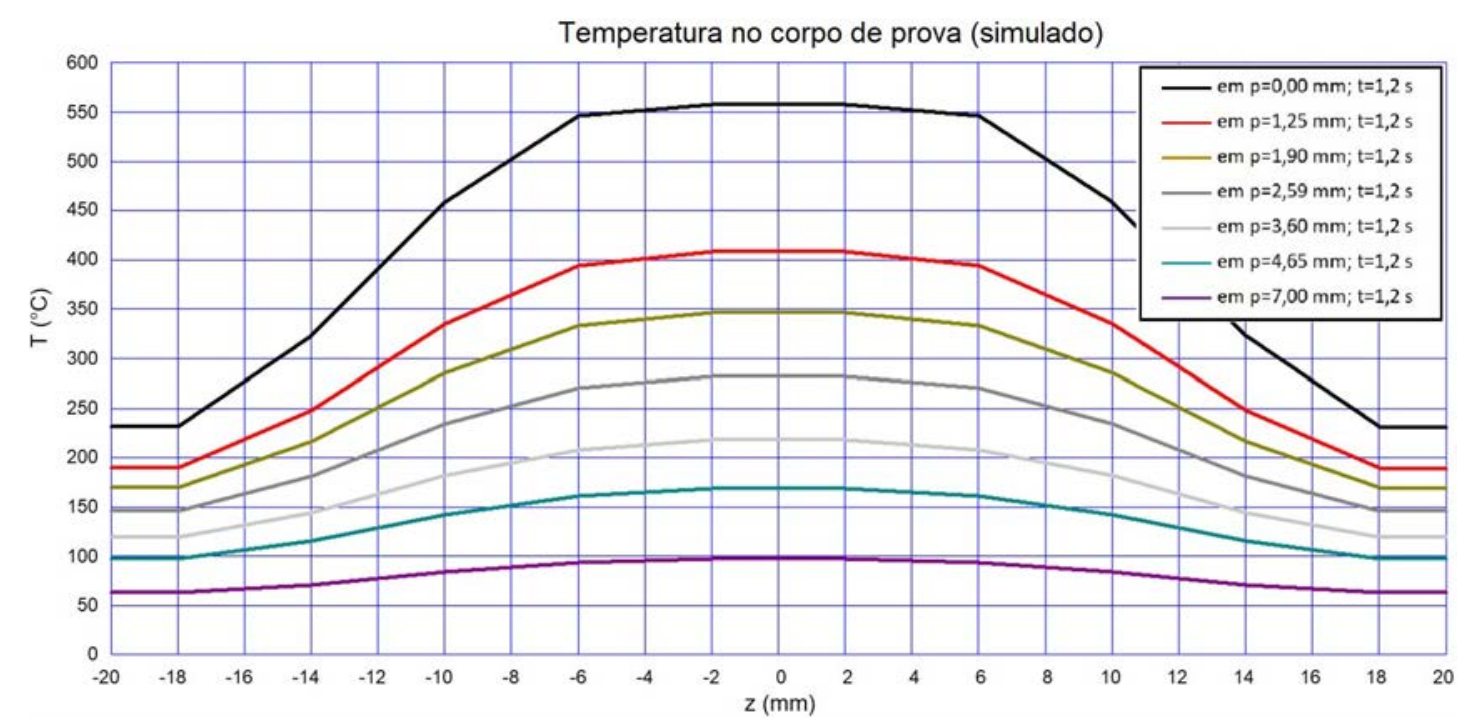

Figura 3.10: Distribuição de temperaturas no corpo de prova provocadas pela bobina, calculados por simulação no software 2DELTA. Na legenda, $\mathrm{p}=$ profundidade em relação à superfície, $\mathrm{t}=$ tempo em relação ao início do aquecimento, $\mathrm{z}=$ distância do centro do $\mathrm{CP}, \mathrm{T}=$ temperatura calculada.

de borracha e parafusos. Desta forma, quando fechada, a única saída de ar da caixa seria a válvula de saída, localizada na parte mais alta da caixa para facilitar a saída de oxigênio, mais leve que o argônio. Os ensaios em atmosfera oxidante foram realizados com a tampa aberta e livre circulação de ar. $O$ sistema de fixação do corpo de prova permite ajustes de posição nos eixos $x$, $y$ e $z$, para centralização do corpo de prova dentro da bobina.

Os parâmetros de controle de temperatura (PV) são temperatura máxima (SP) e histerese (Hyst), ou seja, a variação de temperatura entre a temperatura máxima e a mínima $(\Delta T)$. O valor de histerese é sempre ajustado de modo que a temperatura mínima dos ciclos térmicos seja igual a $110^{\circ} \mathrm{C}$. $\mathrm{O}$ resfriamento externo do corpo de prova é feito ao ar calmo, durante os períodos em que está desligada a fonte de aquecimento. A refrigeração interna é feita por fluxo de água, através de mangueiras conectadas às extremidades do corpo de prova. O controle de pressão de água dentro do corpo de prova é feito através de uma válvula globo ligada a um manômetro analógico e ajustado para $2 \mathrm{~kg} / \mathrm{cm}^{2}$ ( $\left.\approx 28 \mathrm{psi}\right)$. A temperatura da sala é mantida por um ar condicionado a $20 \pm 2{ }^{\circ} \mathrm{C}$. A água mantém a superfície interna do corpo de prova a uma temperatura constante, enquanto a superfície externa aquece e resfria de maneira cíclica, gerando ciclos de gradientes de temperatura e tensões ao longo da espessura.

Nos ensaios com corpos de prova instrumentados, são utilizados termopares tipo $\mathrm{K}$, da marca Ecil, com bainha de $1,5 \mathrm{~mm}$, para o perfil radial. Os dados 
são coletados pelo sistema de aquisição de dados HBM QuantumX MX840 (coleta de dados do pirômetro) e MX1609 (dos termopares) com o software CatmanEasy. A frequência de aquisição de dados tanto do pirômetro quanto do termopar foi ajustada para $200 \mathrm{~Hz}$ (tempo de aquisição $5 \mathrm{~ms}$ ). A coleta de dados de temperatura do pirômetro também pode ser feita separadamente no software LumaSense InfraWin ${ }^{\circledR}$, com tempo de aquisição 0,01 s.

\subsubsection{Avaliação do dano}

Para avaliação do dano no corpo de prova, neste trabalho também se buscou reproduzir alguns métodos utilizados por Medjedoub ${ }^{[3]}$, em particular, a construção das curvas mostradas na Figura 3.11. Essas curvas mostram medidas de densidade de trincas de fadiga térmica superficiais $\left(\rho_{f}\right)$ em função do número de ciclos para diferentes condições de temperatura máxima de ciclo. Medjedoub e Rézaï-Aria utilizaram o parâmetro $\rho_{s t a b}$, que é o limite assintótico da curva, ou seja, a densidade de trincas estável. A partir da geração da densidade de trincas estável, segundo o autor, a evolução do dano de fadiga térmica ocorre para dentro do corpo de prova. Analogamente, o número de ciclos correspondente a $\rho_{\text {stab }}$ foi relacionado ao $N_{f}$ de fadiga. As trincas medidas por esse método são as trincas secundárias e os ensaios foram conduzidos até a formação de uma trinca primária, chamada pelo autor de "macrotrinca".

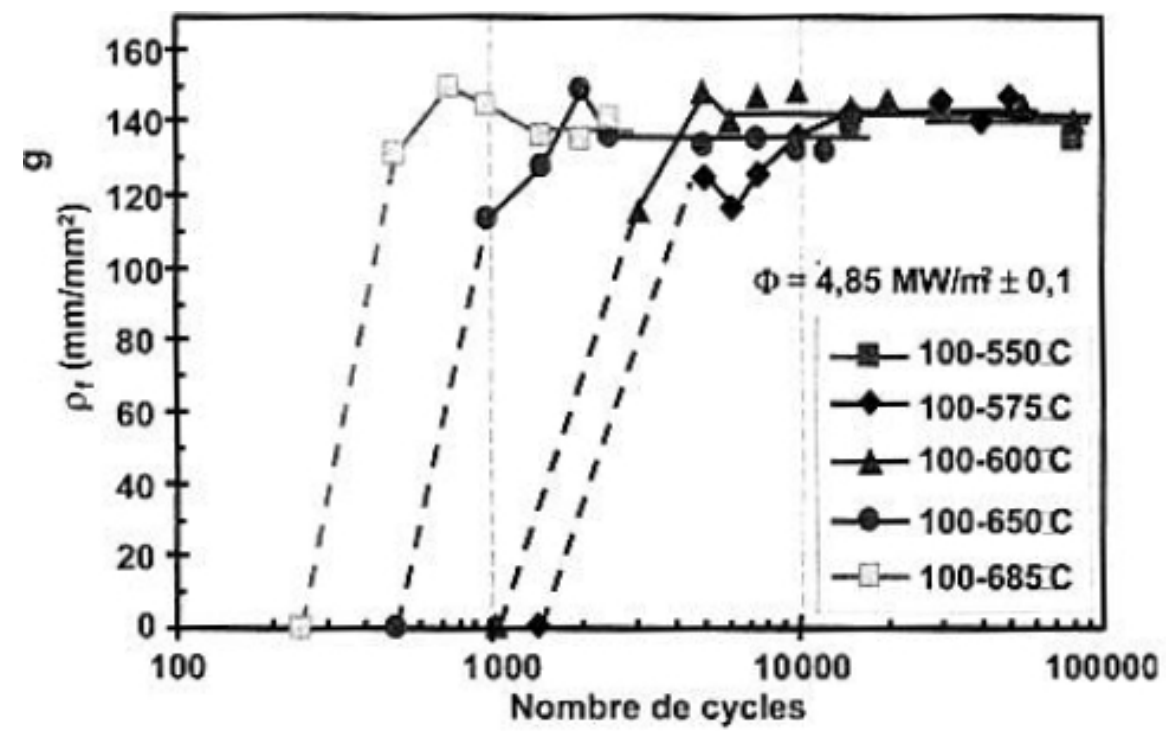

Figura 3.11: Evolução da densidade de trincas microscópicas como função do número de ciclos de fadiga térmica, por Rézaï-Aria ${ }^{[49]}$. Efeito da temperatura máxima.

Neste trabalho, a vida em fadiga $N_{f}$ será considerada o número de ciclos total que o corpo de prova suportou até falhar. Como alguns aspectos das 
condições de ensaio podem exigir tratamentos diferentes, o critério para definir a falha precisou ser adaptado para cada condição. Os critérios adotados foram:

Vazamento de água Nas condições de ensaio ao ar, buscou-se continuar os ensaios até que uma trinca nucleada na superfície interna ou externa propagasse até atingir a superfície oposta, gerando um vazamento de água ou vapor;

Arrancamento de material Nos ensaios em que a propagação de trincas ocorresse em direção diferente da radial, causando conexão entre trincas e arrancamento de material, o ensaio foi interrompido;

Trinca macroscópia Nos ensaios conduzidos em atmosfera de argônio, evitou-se a contaminação da atmosfera por vazamento de água interrompendo-se os ensaios assim que uma trinca macroscópica fosse visível na superfície externa, antes que ela propagasse para o furo.

Os ensaios foram programados para interrupções a cada 1000 ciclos para caracterização da superfície. Sem nenhuma preparação da superfície (limpeza, polimento ou ataque), os corpos de prova eram posicionados no microscópio óptico para obtenção de imagens do padrão de trincas. Entende-se que o dano de fadiga térmica envolve todas as alterações da superfície inicial, ou seja, tanto a região oxidada sobre a matriz quanto as trincas formadas nos carbonetos e/ou superfície.

Como o fluxo de indução é mais concentrado perto das espiras da bobina e diminui para além delas, o centro geométrico da bobina é um caminho de fluxo fraco. Assim, se uma peça fosse colocada fora do centro em uma bobina, a área mais próxima das espiras da bobina cruzaria um maior número de linhas de fluxo e, portanto, seria aquecida a uma taxa maior, enquanto a área da peça com menor acoplamento seria aquecida a uma taxa mais baixa, atingindo temperatura diferente. O padrão resultante é mostrado esquematicamente na Figura 3.12. Este efeito é mais pronunciado no aquecimento por indução de alta frequência. ${ }^{[68]}$ 


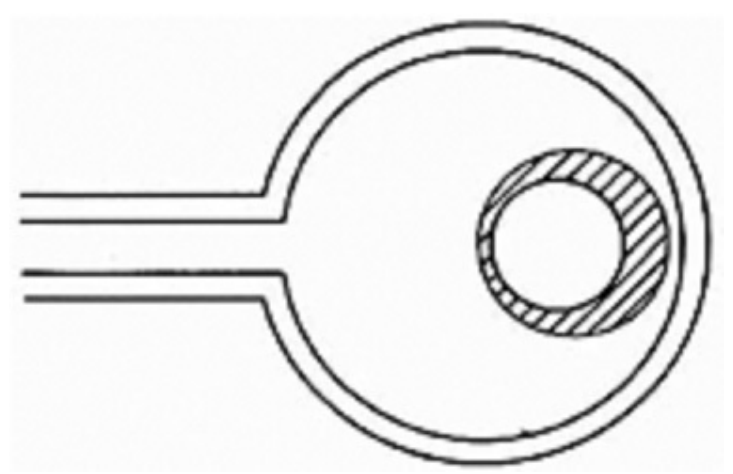

Figura 3.12: Padrão de aquecimento indutivo produzido em uma barra redonda posicionada fora do centro em uma bobina de indução redonda. ${ }^{[6]}$

Para evitar esse efeito de mau posicionamento, a caracterização da superfície foi feita sempre na mesma região do corpo de prova, coincidente com a região central de aquecimento homogêneo (Figura 3.7b e Figura 3.10) em que estava projetado o laser do pirômetro óptico, para garantir que a região a ser analisada sofreu o carregamento térmico correto, uma vez que a heterogeneidade de aquecimento pela bobina é inevitável sem um preciso sistema de posicionamento do corpo de prova no centro da bobina.

É importante ressaltar que todo contato com a superfície foi evitado, desde o instante em que o corpo de prova era montado pela primeira vez na máquina até a preparação da seção transversal. Dessa forma, evitou-se contaminação da superfície que pudesse manchar o corpo de prova e confundir os resultados, além de possível abrasão ou adesão que pudesse causar remoção da camada de óxido formada.

No microscópio, as amostras foram fotografadas com aumentos de 50x, 100x, 200x, 500x e 1000x, sempre em 3 ou mais áreas distintas dentro da mesma região de análise. Para a medição de trincas, uma das fotografias com aumento de 500x foi selecionada e realizou-se o procedimento descrito a seguir.

O dano foi medido pela quantificação da densidade de trincas superficiais como a relação entre o comprimento total de trincas e a área da região analisada. A medição das trincas foi realizada no software ADCIS Aphelion Lab 4.3.2, utilizando as fotografias de MO. Com ajuda de um software de manipulação de imagem, foram desenhadas sobre as fotografias as trincas e as intersecções entre elas, em cores diferentes (Figura 3.13).

A identificação das trincas foi feita com a ferramenta "Object Extraction", método automático, Color Space YIQ, com processamento da banda I. O 


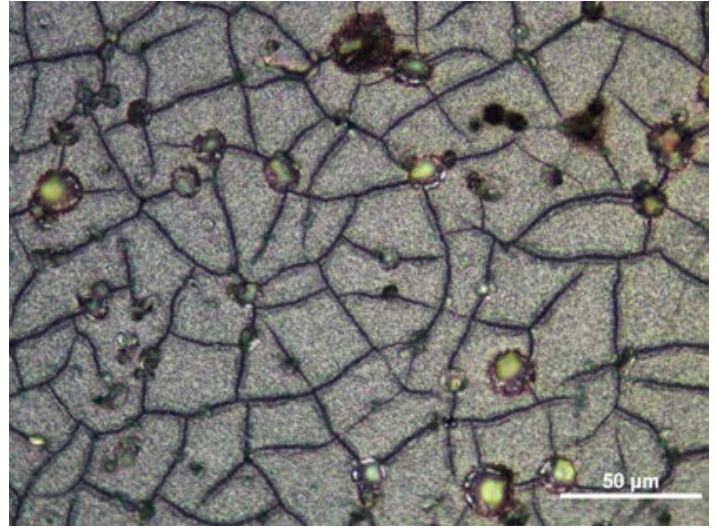

(a)

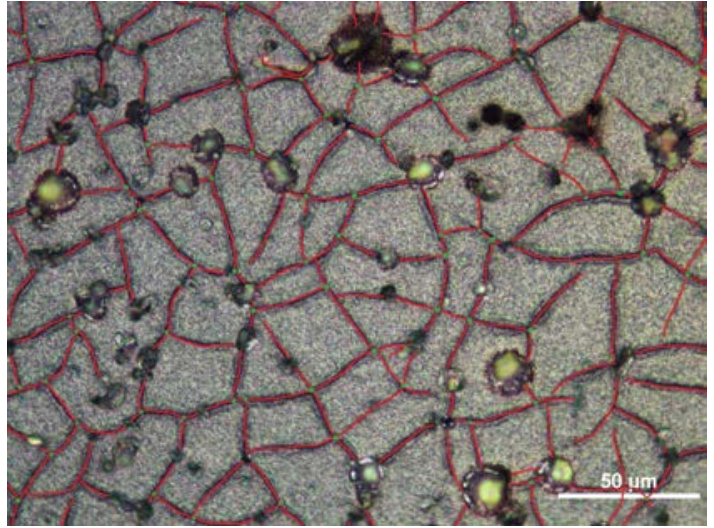

(b)

Figura 3.13: Marcação de uma fotografia de microscópio óptico para medição de trincas. (a) Imagem original, com aumento de 500x; (b) Destaque das trincas e interseções com cores vermelha e verde, respectivamente, para facilitar a identificação das trincas no software de análise de imagem.

threshold foi alterado de modo a selecionar automaticamente as regiões claras, com filtro gaussiano de 3 px. Após a seleção das trincas, foi utilizada a ferramenta "Object Measurements", que calcula, entre outros parâmetros, o MBR.Width (Minimum Bounding Rectangle Width, Figura 3.14), que é a largura do menor retângulo que contenha a trinca. Esse parâmetro foi utilizado como medida do comprimento de trinca e, portanto, a densidade de trincas é a soma de todos os comprimentos de trincas dividida pela área da figura (Equação (3.1)). A tela do software é mostrada na Figura 3.15.

$$
\rho=\frac{\sum_{i} \text { MBR. Width }_{i}}{\text { Área da Figura }}\left[\mathrm{mm} / \mathrm{mm}^{2}\right]
$$

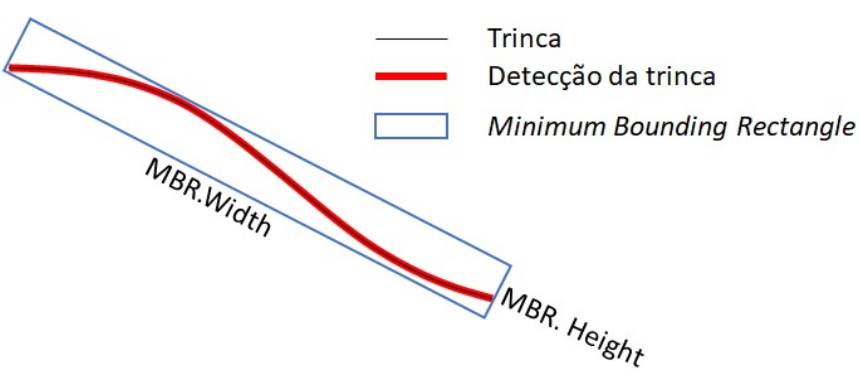

Figura 3.14: Esquema de criação do $M B R=$ Minimum Bounding Rectangle sobre a detecção de uma trinca. A trinca está desenhada com uma linha preta, enquanto a deteç̧ão automática é representada em vermelho. O MBR é desenhado em azul. A maior dimensão do retângulo é chamada MBR.Width e a menor dimensão é a MBR.Height. 


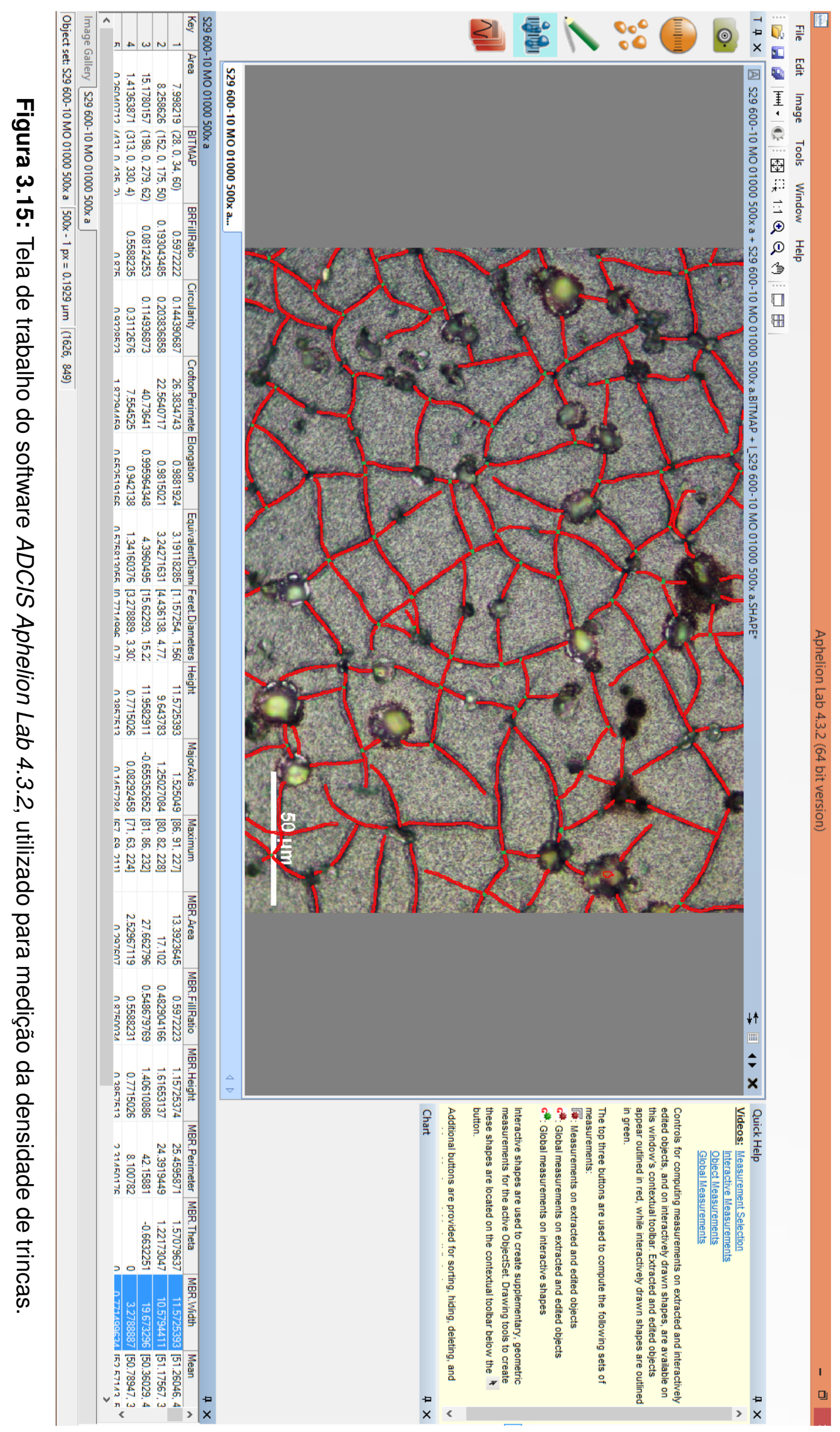


Após o término dos ensaios, os corpos de prova foram divididos em 2 grupos para caracterização adicional:

1. 2 CPs de cada condição, para análise da seção transversal.

Os corpos de prova foram cortados ao meio no comprimento, embutidos e polidos e a seção transversal foi analisada em microscópio óptico e/ou de varredura sem ataque ou com ataque de ácido pícrico para visualização dos contornos de grão.

2. $1 \mathrm{CP}$ de cada condição, para tomografia de raios-X.

Os corpos de prova foram medidos no tomógrafo de raios- $X$ do IPT, fabricado pela Werth Messtechnik GmbH. Os parâmetros de ajuste da medição são:

- Corrente: $280 \mu \mathrm{A}$

- Tensão: 210 kV

- Tempo de Exposição: 2 segundos

- Média de imagens: 2 imagens

- Filtro: $3 \mathrm{~mm}$ de Estanho $(\mathrm{Sn})+1 \mathrm{~cm}$ de Aço (estilete)

- Janela de medição: 50 mm x 5 mm (medido em 3 posições para varrer a peça toda)

- Faixa de resolução: $15 \mu \mathrm{m}$ - $30 \mu \mathrm{m}$

As análises das imagens foram feitas nos softwares VGStudio MAX ${ }^{\circledR}$ 2.1 (em cortes) e MyVGL ${ }^{\circledR}$ (renderização 3D). Buscou-se visualizar o lugar de nucleação e o caminho de propagação das trincas primárias ao longo dos corpos de prova, sem a realização de cortes mecânicos ou por eletroerosão, que podem causar alteração na microestrutura, nucleação de novas trincas ou deformação ou propagação das trincas existentes, mascarando o resultado real.

\subsubsection{Cálculos de tensões na superfície}

As tensões na superfície foram calculadas por Método de Elementos Finitos utilizando o modelo criado pela equipe da Poli-LFS para o ensaio de fadiga térmica do IPT. As entradas para os cálculos foram os perfis de temperatura obtidos conforme descreve a próxima sessão. 
Foi desenvolvido um modelo não linear elasto-plástico em elementos finitos no software comercial Abaqus/Standard. A malha foi construída com 7269 nós e 7022 elementos axissimétricos com graus de liberdade térmicos e estruturais (CAX4T), com dimensão de $200 \mu \mathrm{m} \times 200 \mu \mathrm{m}$ na região de trabalho. Foram impostas evoluções temporais de temperatura na superfície e nas profundidades de 1,25, 1,90, 2,55, 3,60, 4,65 e 7,00 mm na região de trabalho, as mesmas profundidades onde os dados de temperatura foram coletados no experimento instrumentado, e a temperatura entre os pontos de entrada foi calculada por condução térmica.

O modelo é restrito apenas por uma condição de simetria no plano médio do corpo de prova, cortando sua seção transversal, com a condição de axissimetria provendo as restrições adicionais necessárias. O resfriamento do corpo de prova é simulado por uma convecção aplicada à superfície interna, supondo temperatura de $22^{\circ} \mathrm{C}$ e coeficiente de convecção de 12,566 $\mathrm{W} /\left(\mathrm{m}^{2} \cdot \mathrm{K}\right)$. No modelo, o material foi considerado homogêneo e a matriz foi modelada com propriedades do aço AISI H13 obtidas tanto da literatura quanto de dados levantados em experimentos a frio e a quente ${ }^{[30]}$ (dados da matriz do C99 na Tabela 2.2, pág. 35). 


\subsection{Ensaios preliminares}

Antes de iniciar os ensaios de fadiga térmica definitivos, foram feitos ensaios preliminares para verificar os seguintes aspectos:

1. Medição do tempo de aquecimento, tempo de resfriamento e tempo total de ciclo para as condições de ensaio

2. Tempo para estabelecimento de um ciclo regular de calor e regularidade do ensaio

3. Precisão do controlador em interromper o aquecimento nas temperaturas especificadas - medição do overshoot

4. Efeito da pressão de água nas curvas de aquecimento e resfriamento

\subsubsection{Tempo, temperatura e regularidade do ensaio}

Foram realizados 10 ciclos consecutivos de aquecimento/resfriamento dos corpos de prova, segundo 6 condições de variação de temperatura e potência do forno, a fim de levantar os valores reais de temperatura na superfície dos corpos de prova e tempos de aquecimento e resfriamento. A Tabela $\mathbf{3 . 2}$ mostra os valores de temperatura máxima em cada ciclo, para cada uma das 6 condições de ensaio. Os valores tornam-se repetitivos logo a partir do primeiro ciclo de aquecimento e, portanto, assume-se que o ensaio esteja em regime constante. 
Tabela 3.2: Resumo dos dados das curvas de ciclos térmicos em 6 condições de ensaio de fadiga térmica.

\begin{tabular}{|c|c|c|c|c|c|c|}
\hline Condição & 1 & 2 & 3 & 4 & 5 & 6 \\
\hline Temperatura & 600 & 600 & 600 & 650 & 650 & 650 \\
\hline Potência (\%) & 60 & 80 & 95 & 60 & 80 & 95 \\
\hline \multicolumn{7}{|l|}{ ciclo } \\
\hline 1 & 605,2 & 608,9 & 608,7 & 654,0 & 656,3 & 658,8 \\
\hline 2 & 604,9 & 607,9 & 610,4 & 653,3 & 656,6 & 659,2 \\
\hline 3 & 604,9 & 609,3 & 610,7 & 654,0 & 655,8 & 659,7 \\
\hline 4 & 604,1 & 609,3 & 611,4 & 653,6 & 655,5 & 658,8 \\
\hline 5 & 604,8 & 607,2 & 612,5 & 653,9 & 656,4 & 658,5 \\
\hline 6 & 605,2 & 607,2 & 611,5 & 653,9 & 656,2 & 657,9 \\
\hline 7 & 604,9 & 608,6 & 612,2 & 664,4 & 657,2 & 659,8 \\
\hline 8 & 605,0 & 608,8 & 609,1 & 653,4 & 655,7 & 658,8 \\
\hline 9 & 604,9 & 608,7 & 609,6 & 654,4 & 655,9 & 658,1 \\
\hline 10 & 604,5 & 609,4 & 608,9 & 654,4 & 655,7 & 657,6 \\
\hline Média & 604,8 & 608,5 & 610,5 & 654,9 & 656,1 & 658,7 \\
\hline Overshoot & 4,8 & 8,5 & 10,5 & 4,9 & 6,1 & 8,7 \\
\hline \multicolumn{7}{|l|}{ Tempo } \\
\hline Aquecimento & 4,24 & 1,95 & 1,43 & 5,25 & 2,50 & 1,70 \\
\hline Resfriamento & 23,77 & 19,50 & 18,25 & 26,56 & 22,07 & 20,05 \\
\hline Total & 28,01 & 21,45 & 19,67 & 31,81 & 24,57 & 21,75 \\
\hline
\end{tabular}

O tempo de aquecimento é tanto menor quanto maior a potência aplicada pelo forno sobre o corpo de prova, devido ao aumento do fluxo de calor para o corpo de prova. Obviamente, o tempo de aquecimento para temperaturas superiores também é maior. O tempo de resfriamento depende não só da temperatura máxima do ciclo, como também do tempo de aquecimento. Se o aquecimento for mais lento, há maior propagação de calor para o centro do corpo de prova, levando também mais tempo para resfriar até a temperatura mínima. Supõe-se também que quanto mais rápido o aquecimento para uma dada temperatura, maior é o gradiente térmico próximo à superfície. 


\subsubsection{Teste de resposta do controlador}

Como pode ser visto na Tabela 3.2, olhando-se para a temperatura máxima real em relação à temperatura de setup, o controlador do ensaio de fadiga térmica tem precisão suficiente para interromper o aquecimento com um erro na temperatura (overshoot) de 4 a $11{ }^{\circ} \mathrm{C}$ acima da temperatura especificada como Temperatura máxima. Como essa diferença é muito pequena em relação ao tamanho do $\Delta T$, pode ser desprezada.

\subsubsection{Efeito da pressão de água no aquecimento e resfria- mento}

A água no interior do corpo de prova atua como sorvedor de calor, que flui da superfície externa para a interna. A perda de calor também ocorre por radiação para o ambiente, conservado a $20^{\circ} \mathrm{C}$ pelo ar condicionado.

A temperatura da água que flui pelo corpo de prova é proveniente do circuito fechado de água industrial do prédio onde está instalado o equipamento. Sua temperatura não é controlada no ensaio, mas é assumido, com base em medições realizadas em projetos anteriores, que seja aproximadamente $20^{\circ} \mathrm{C}$. Todos os ensaios foram realizados entre os meses janeiro e maio de 2017, período de altas temperaturas em São Paulo. Foi verificado durante os ensaios preliminares que, dentro da faixa de valores de pressão que é possível variar para o fluxo de água ( 0 a 40 psi), acima de 20 psi o efeito da pressão é irrelevante no tempo de resfriamento. Portanto, será utilizada em todos os ensaios a pressão de $2 \mathrm{~kg} / \mathrm{cm}^{2}$ de água (28 psi).

\subsubsection{Seleção da condição de referência}

Para selecionar a temperatura dos ensaios na condição de referência e na condição de temperatura alta (REF e HOT), foram feitos testes com 3 corpos de prova, ensaiados a 500,550 e $600^{\circ} \mathrm{C}$, medindo a densidade de trincas secundárias. Os resultados são mostrados na Figura 3.16. Conforme disseram Rézaï-Aria e Medjedoub ${ }^{[3,49]}$, a temperatura do ensaio não influencia na densidade de trincas, mas no número de ciclos para a nucleação e para o fim da vida. Isso foi comprovado com estes ensaios. Deste modo, a fim de acelerar os ensaios, foi escolhida como referência a temperatura de $600^{\circ} \mathrm{C}$. 


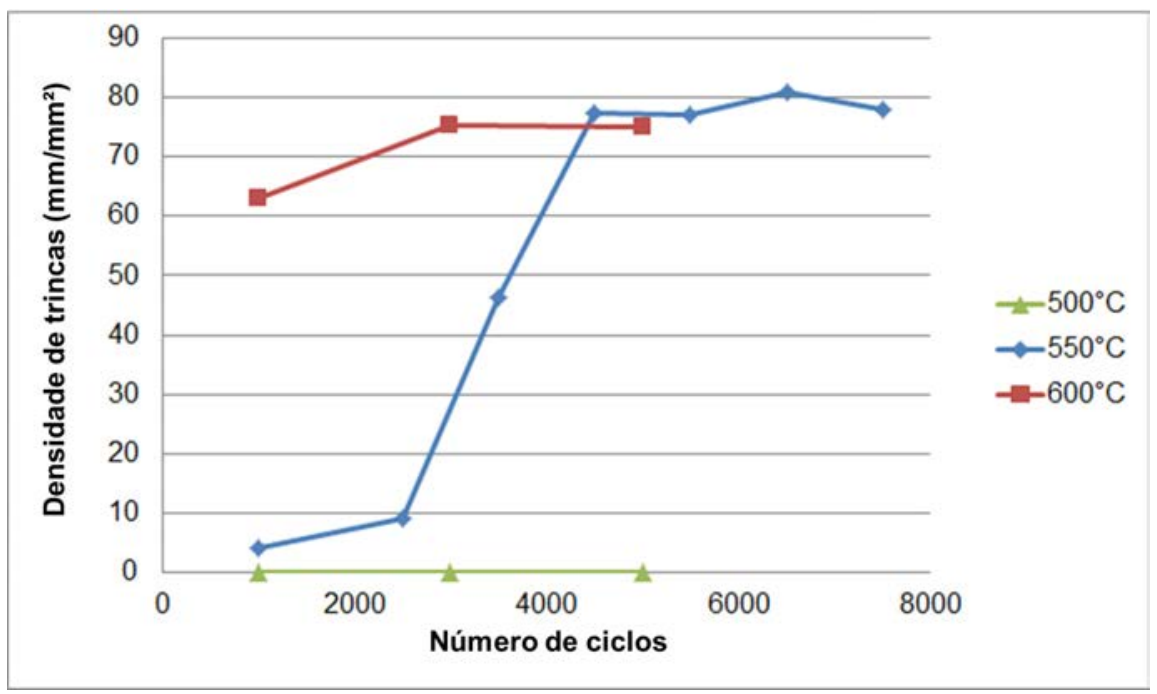

Figura 3.16: Medidas de densidade de trincas secundárias em corpos de prova ensaiados em diferentes temperaturas, para seleção da temperatura dos ensaios de referência.

\subsection{Projeto de experimentos}

As condições de ensaio foram dispostas em uma matriz de experimentos que possibilitasse a comparação entre duas amostras com a variação de apenas 1 parâmetro por vez, para evitar que efeitos diferentes se sobrepusessem e mascarassem os mecanismos que se deseja estudar. Para validar os resultados, cada condição foi ensaiada em triplicata.

A matriz de experimentos utilizada é mostrada na Tabela 3.3: 
Tabela 3.3: Matriz de experimentos, com 5 condições de aquecimento, atmosfera e dureza, em triplicata.

\begin{tabular}{c|c|c|c|c}
\hline $\begin{array}{c}\text { Condição } \\
\text { (núm. CP) }\end{array}$ & $\begin{array}{c}\text { Temperatura } \\
\left({ }^{\circ} \mathrm{C}\right)\end{array}$ & $\begin{array}{c}\text { Potência } \\
(\mathrm{kW})\end{array}$ & Atmosfera & $\begin{array}{c}\text { Dureza } \\
\left(\mathrm{HR}_{C}\right)\end{array}$ \\
\hline REF1 & 600 & 21 & ar & 51 \\
REF2 & 600 & 21 & ar & 51 \\
REF3 & 600 & 21 & ar & 51 \\
\hline LOW1 & 600 & 10 & ar & 52 \\
LOW2 & 600 & 10 & ar & 52 \\
LOW3 & 600 & 10 & ar & 52 \\
\hline HOT1 & 650 & 20 & ar & 51 \\
HOT2 & 650 & 20 & ar & 52 \\
HOT3 & 650 & 20 & ar & 51 \\
\hline ARG1 & 600 & 20 & Argônio & 53 \\
ARG2 & 600 & 20 & Argônio & 52 \\
ARG3 & 600 & 21 & Argônio & 51 \\
\hline REV1 & 600 & 20 & ar & 40 \\
REV2 & 600 & 20 & ar & $\mathbf{4 0}$ \\
REV3 & 600 & 20 & ar & $\mathbf{4 0}$ \\
\hline
\end{tabular}

A condição de referência (REF) era composta dos seguintes parâmetros:

- Temperatura máxima: $600^{\circ} \mathrm{C}$;

- Velocidade de aquecimento: Rápida - Potência do forno de 20-22 kW¹;

- Dureza: 51-53 HRC;

- Atmosfera: Ao ar calmo (oxidante).

Os parâmetros variantes nas demais condições de ensaio são:

HOT Temperatura máxima: $650^{\circ} \mathrm{C}$;

LOW Velocidade de aquecimento: Lenta - Potência do forno de 10 kW;

ARG Atmosfera: Argônio analítico 5.0, vazão 30 l/min (não oxidante);

REV Dureza: $40 \mathrm{HR}_{C}$ (super-revenido).

${ }^{1}$ A potência do forno era regulada na posição máxima, porém a potência real, mostrada no painel, variava com algumas condições de aquecimento ou corpos de prova. 
A dureza de $40 \mathrm{HR}_{C}$ dos corpos de prova da condição REV foi obtida após um tratamento térmico adicional de revenimento a $700^{\circ} \mathrm{C}$ por 1 hora, resultando em uma microestrutura super-revenida. Durante os ensaios de fadiga térmica, o ciclo térmico foi o mesmo da condição de referência, até $600^{\circ} \mathrm{C}$.

Os parâmetros que foram iguais para todas as condições foram:

- Temperatura mínima: $110^{\circ} \mathrm{C}$;

- Pressão de água: $2 \mathrm{~kg} / \mathrm{cm}^{2}(\approx 6,8 \mathrm{l} / \mathrm{min})$;

- Temperatura do ambiente externo (ar e água): $20 \pm 2^{\circ} \mathrm{C}$.

A Figura 3.17 resume as condições de ensaio de fadiga térmica e as variações de parâmetros, em relação à condição de referência, REF. O sentido das setas indica o aumento do parâmetro que está sendo alterado.

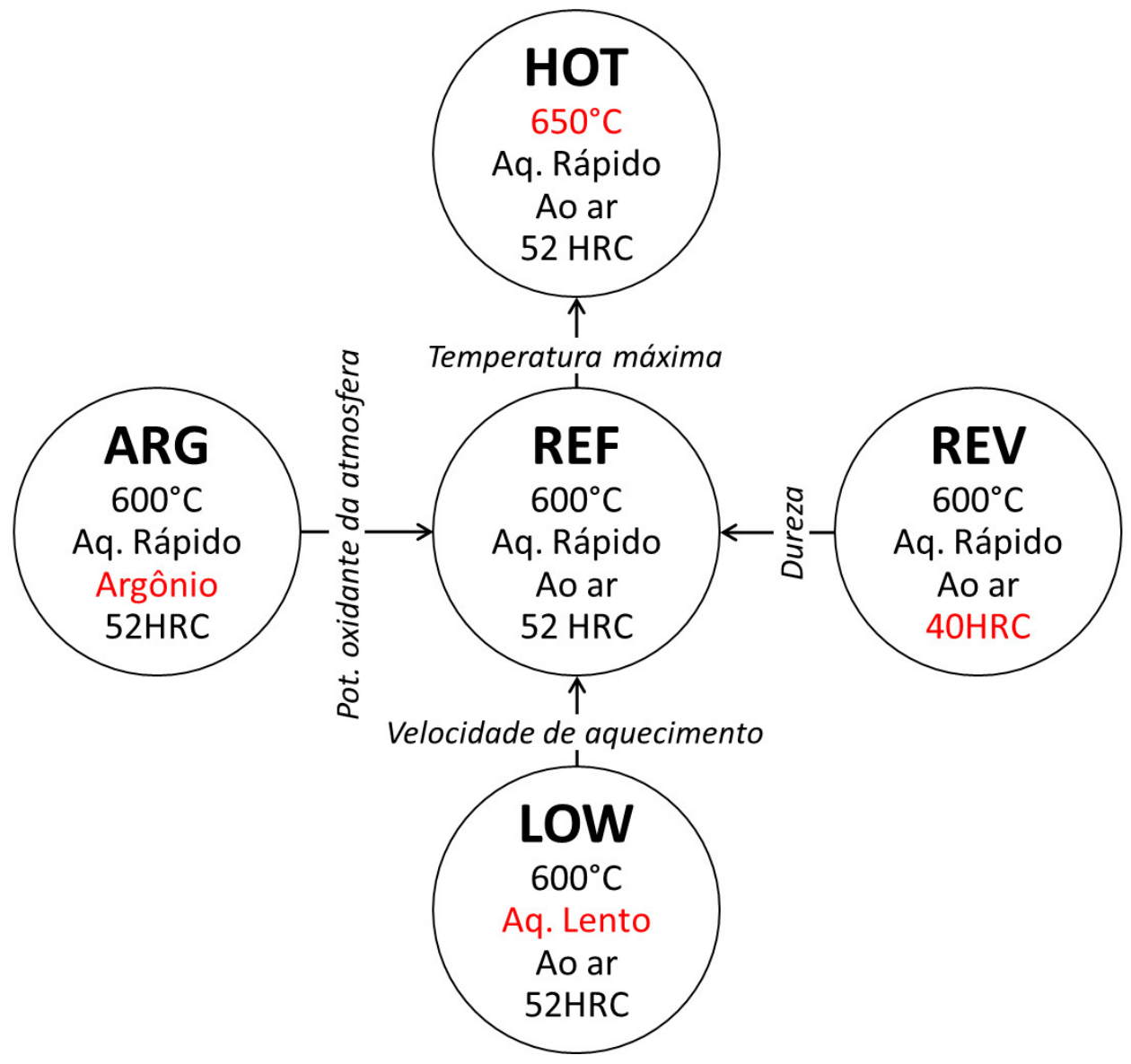

Figura 3.17: Condições de ensaio de fadiga térmica para avaliação dos parâmetros. As condições HOT, LOW, ARG e REV são variações dos parâmetros destacados em vermelho (Temperatura máxima, Velocidade de aquecimento, Potencial oxidante da atmosfera e Dureza). 
4 Resultados 



\subsection{Ensaios de oxidação estática}

Foi possível observar, após o preparo das amostras por FIB, como a espessura dos óxidos formados na superfície pode variar com a temperatura de aquecimento. A Figura 4.1 mostra uma comparação da camada oxidada sobre o material após aquecimento por 120 minutos, nas quatro temperaturas estudadas.

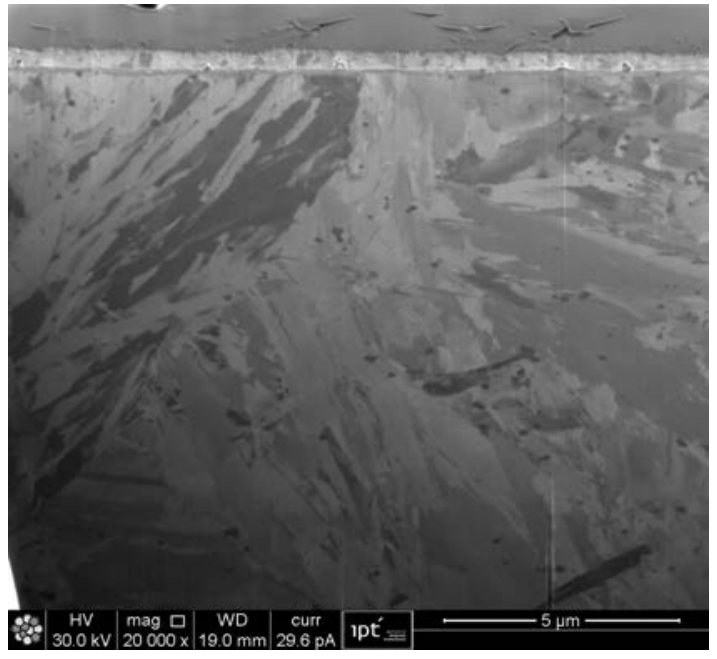

(a)

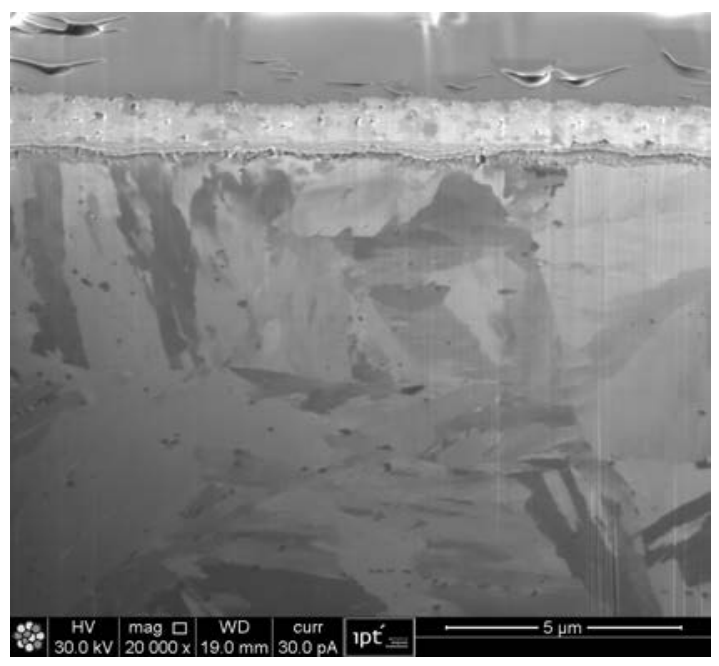

(c)

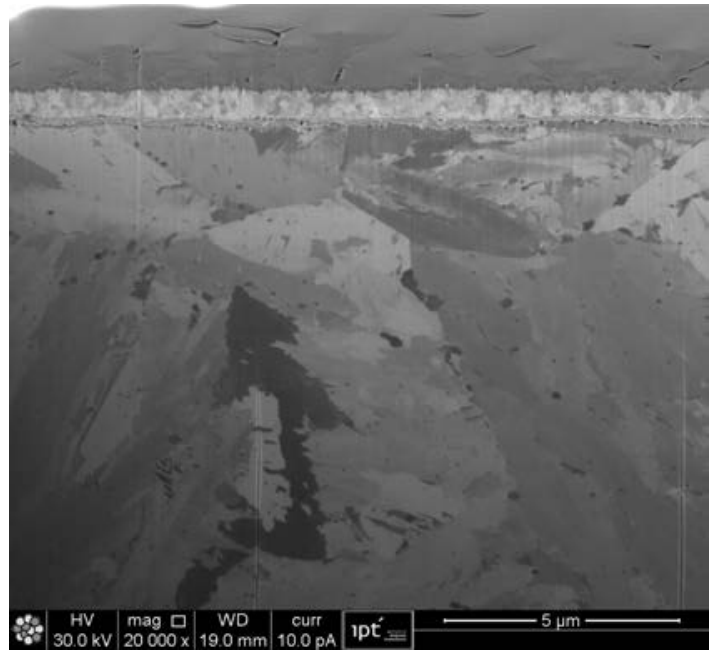

(b)

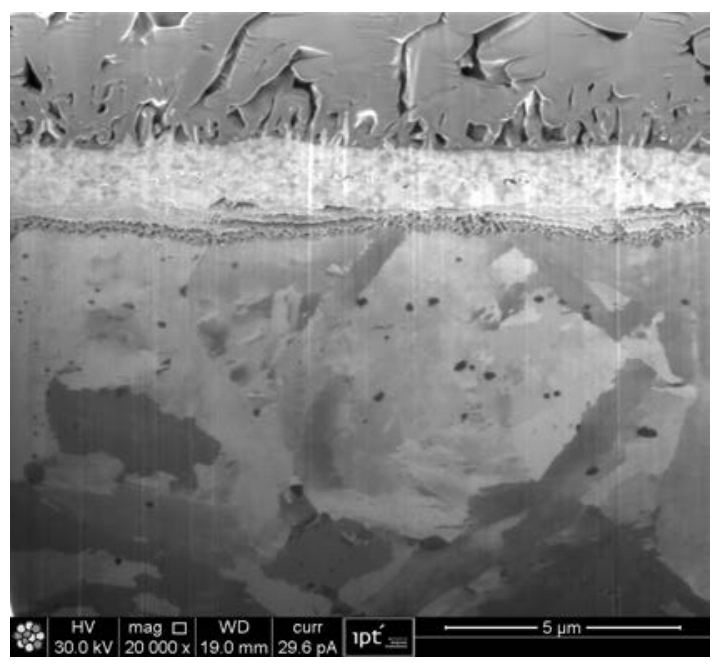

(d)

Figura 4.1: Observação do aumento da espessura da camada de óxidos formados após aquecimento por 120 minutos em diferentes temperaturas. (a) $500^{\circ} \mathrm{C}$; (b) $550^{\circ} \mathrm{C}$; (c) $600^{\circ} \mathrm{C}$; (d) $650^{\circ} \mathrm{C}$.

As amostras foram cortadas e embutidas para visualização da seção transversal no microscópio óptico (Figura 4.2, amostras oxidadas a $600^{\circ} \mathrm{C}$ ). Os sítios preferenciais para o início da oxidação são interfaces com carbonetos (circulados na figura), chegando a consumir toda a região ao redor deles (círculos 
vermelhos). Após caracterização das amostras polidas, foi realizado ataque metalográfico para tentar correlacionar os pontos de oxidação preferencial a alguma característica da microestrutura, como mostra a Figura 4.3. É possível relacionar os pontos de oxidação preferencial distantes de carbonetos (indicados por setas na figura) a contornos de grão da matriz.
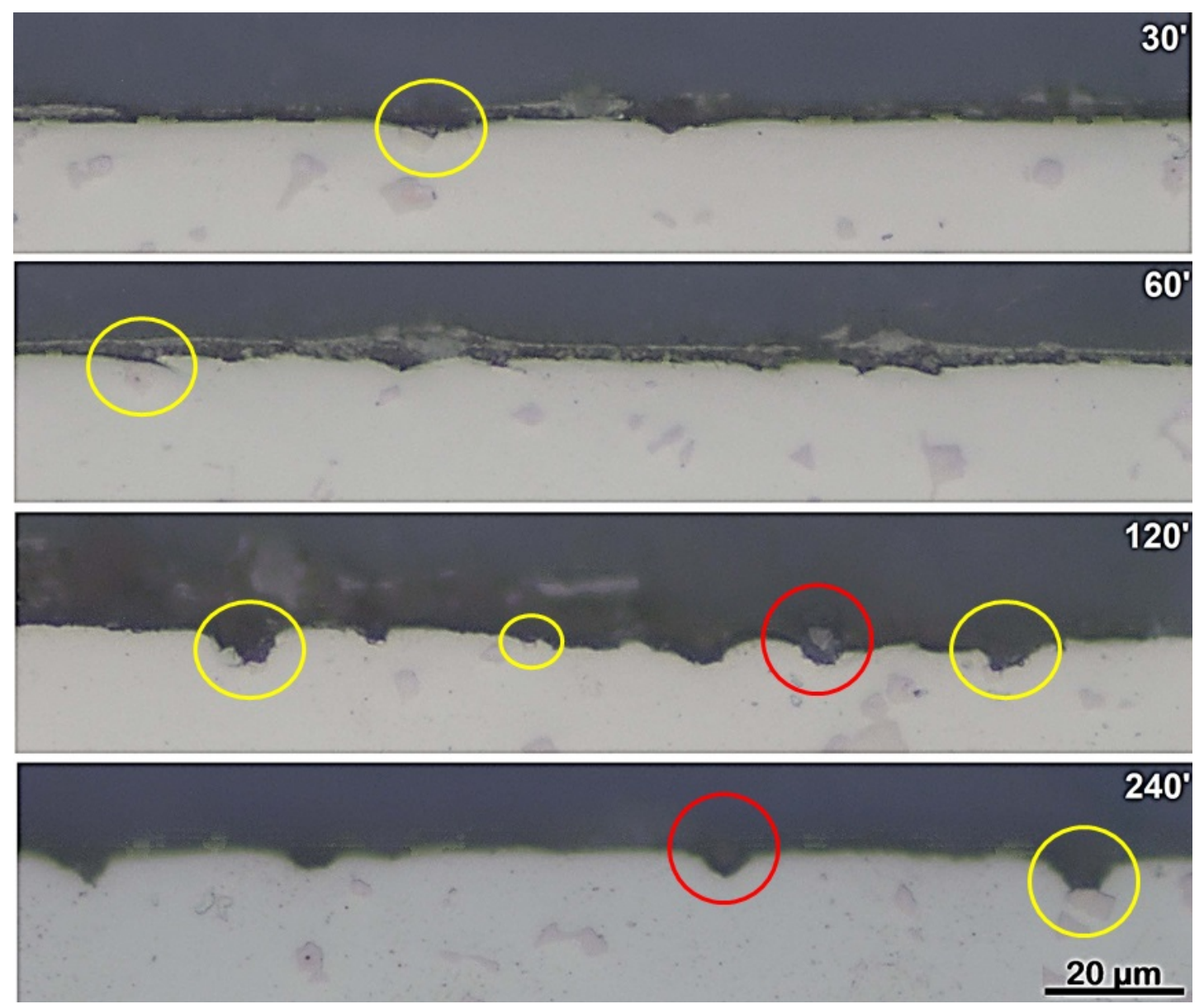

Figura 4.2: Oxidação da superfície de amostras aquecidas até $600^{\circ} \mathrm{C}$, por diferentes períodos (30 a $240 \mathrm{~min}$ ). Amostras polidas, sem ataque, aumento de 500x. Nota-se que a oxidação começa pelas regiões de interface com os carbonetos e avança de modo a tomar outras regiões aparentemente livres de partículas de segunda fase. Círculos indicam regiões oxidadas próximas a carbonetos. Círculos vermelhos indicam carbonetos cercados de óxido. 

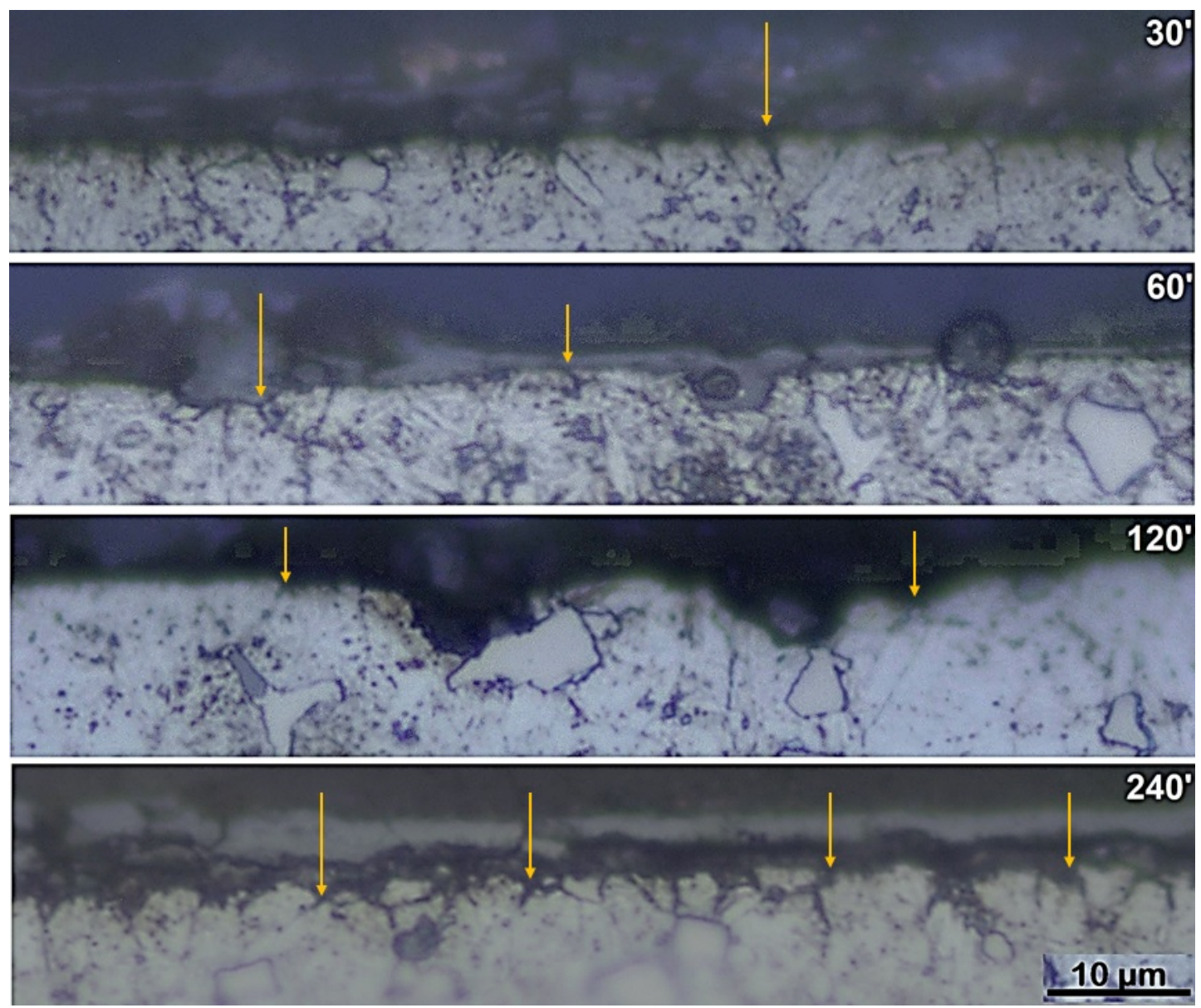

Figura 4.3: Oxidação da superfície de amostras aquecidas até $600^{\circ} \mathrm{C}$, por diferentes períodos (30 a $240 \mathrm{~min}$ ). Amostras polidas, com ataque Nital 2\%, aumento de 1000x. Percebe-se que as regiões de oxidação preferencial, além dos carbonetos, são os contornos de grão, que ficam bastante demarcados após 240 minutos (indicados por setas).

\subsubsection{Análise dos óxidos}

As regiões da seção transversal das amostras ensaiadas a $600^{\circ} \mathrm{C}$ por $60 \mathrm{mi}-$ nutos e por 240 minutos foram levadas, embutidas, ao microscópio eletrônico de varredura para fotografias e análise química semiquantitativa por espectroscopia de energia dispersiva (EDS). É possível confirmar o que foi dito anteriormente sobre os pontos de oxidação preferencial, nos carbonetos e nos contornos de grão. Alguns casos são mostrados na Figura 4.4. 


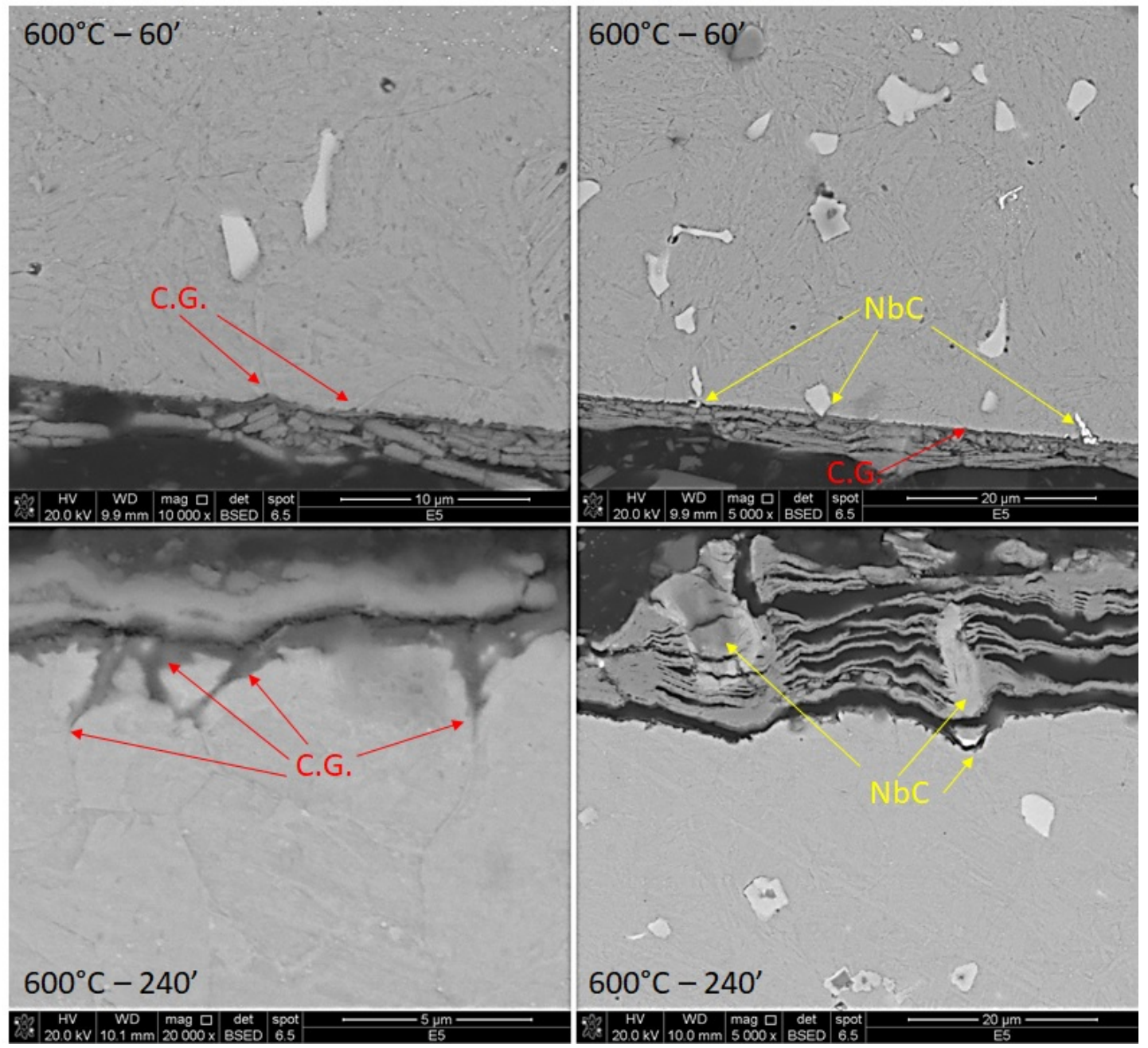

Figura 4.4: Pontos de oxidação preferencial em contornos de grão (C.G.) e carbonetos $\mathrm{NbC}$ observados nas amostras oxidadas a $600^{\circ} \mathrm{C}$. À esquerda, oxidação em contornos de grão. À direita, oxidação em carbonetos próximos à superfície.

A análise por EDS mostra duas composições químicas distintas da camada de óxido (Figura 4.5) quando localizada próxima ao metal (com cromo e vanádio) ou na face externa (sem cromo e vanádio). O EDS também mostra composição química diferente do óxido quando formado a partir dos carbonetos de nióbio (Figura 4.6). Devido à incerteza na medida por EDS, não é possível afirmar qual óxido de ferro foi formado ( $\mathrm{FeO}, \mathrm{Fe}_{2} \mathrm{O}_{3}$ ou $\mathrm{Fe}_{3} \mathrm{O}_{4}$ ). É provável que o carbono presente na baquelite tenha contaminado a região de borda. Além disso, costuma-se desconsiderar resultados de detecção de carbono por EDS, devido às várias fontes de contaminação de amostras e erros de medição intrínsecos do método. 

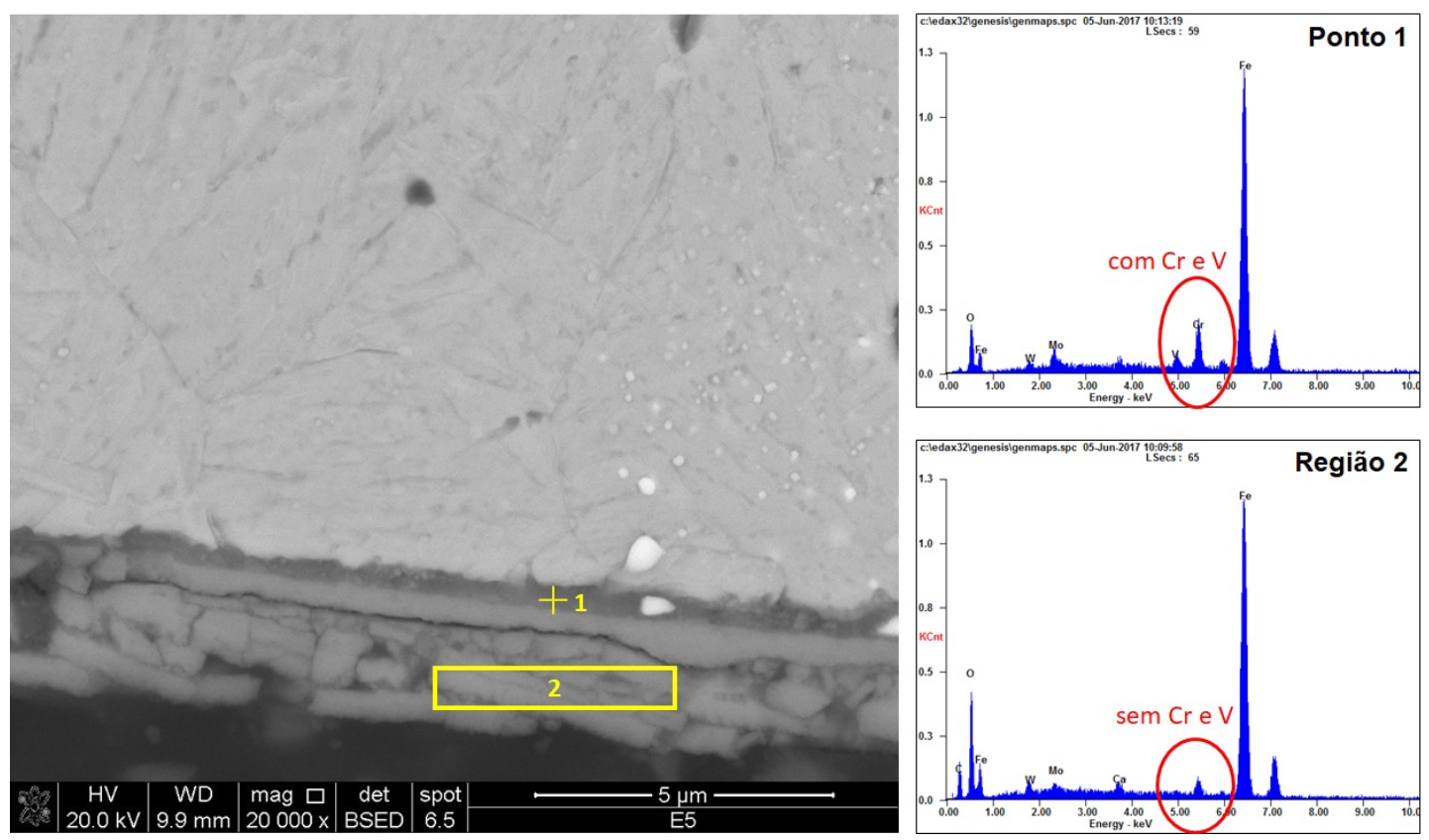

Figura 4.5: Análises de composição química por EDS na camada de óxido de amostras oxidadas a $600^{\circ} \mathrm{C}$. O ponto 1, próximo ao metal, acusa presença de cromo, que está ausente na camada externa, medida na região 2 . No entanto, devido à espessura da região, a medida pode ter sido influenciada pela matriz.

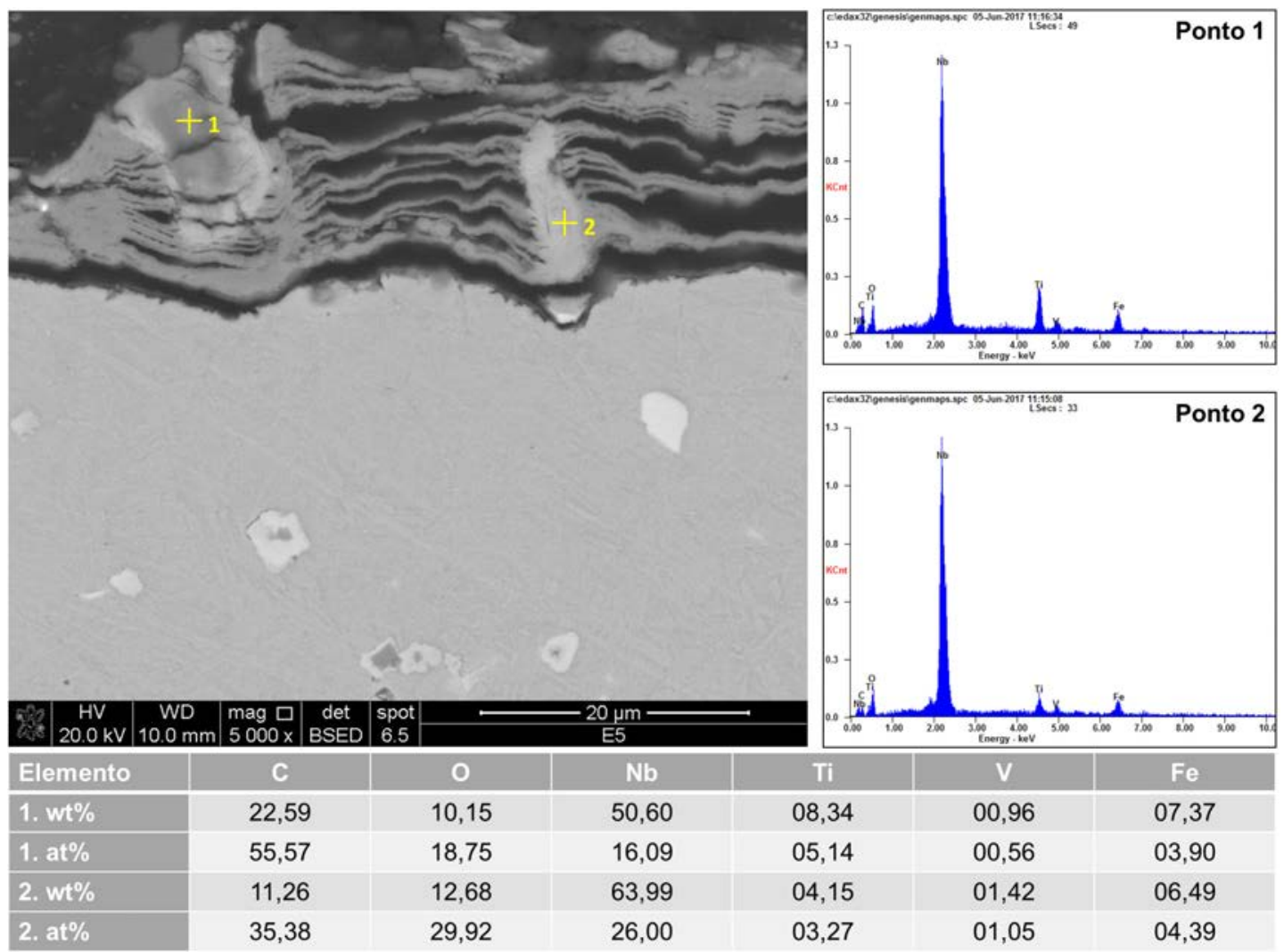

Figura 4.6: Análises de composição química por EDS na camada de óxido formada sobre os carbonetos de nióbio oxidados a $600^{\circ} \mathrm{C}$. Há presença de titânio (nucleante) e vanádio (dissolve no $\mathrm{NbC}$ ). 
Nas regiões de óxido de ferro próximas aos carbonetos de nióbio, como na parte inferior direita da Figura 4.4 e na Figura 4.7, é possível ver a oxidação também dos carbonetos, com morfologia diferente. Enquanto o óxido de ferro se apresenta na forma de placas e pode se destacar do substrato em regiões de menor aderência, o óxido de nióbio é compacto e parece manter as lamelas de óxido de ferro unidas, mesmo depois de se desprenderem do metal (Figura 4.6).

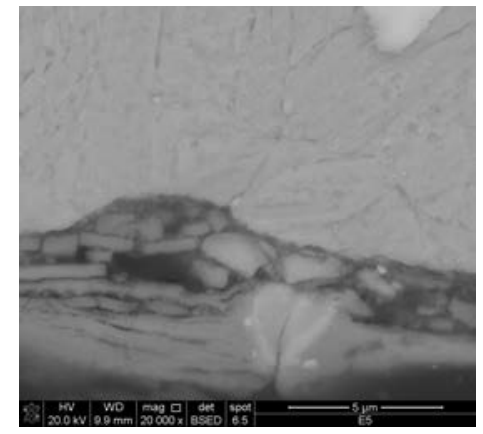

(a)

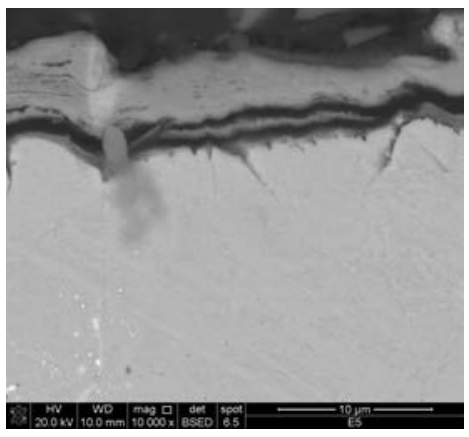

(b)

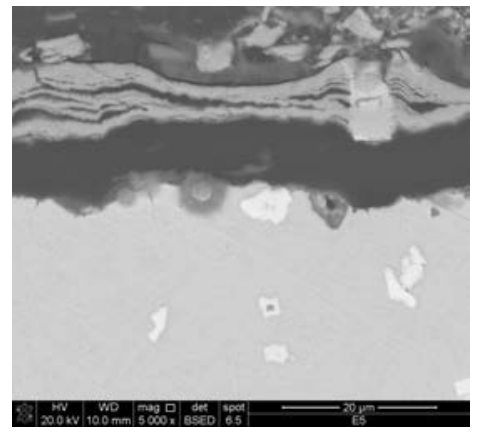

(c)

Figura 4.7: Regiões de formação de camada de óxidos sobre a matriz de aço e os carbonetos de nióbio. (a) Morfologia do óxido de ferro particulada e do óxido de nióbio compacto; (b) Desprendimento da camada de óxido da matriz, ancorada pelo carboneto; (c) Desprendimento total da camada, com o óxido de nióbio mantendo-a coesa.

\subsubsection{Medição de espessura}

A medida de espessura de óxidos após o corte por FIB foi feita sobre todas as camadas sobrepostas, no caso de existir mais de um tipo de óxido na superfície. As espessuras de óxidos medidas nas 16 amostras são mostradas na Tabela 4.1 e no gráfico da Figura 4.8. 
Tabela 4.1: Medidas da camada de óxido sobre as amostras oxidadas em temperaturas e tempos diferentes.

\begin{tabular}{c|c|c}
\hline Temperatura $\left({ }^{\circ} \mathrm{C}\right)$ & Tempo (minutos) & Espessura (nm) \\
\hline \multirow{3}{*}{500} & 30 & 123 \\
& 60 & 188 \\
& 120 & 527 \\
& 240 & 814 \\
\hline \multirow{5}{*}{550} & 30 & 232 \\
& 60 & 313 \\
& 120 & 826 \\
& 240 & 921 \\
\hline \multirow{5}{*}{600} & 30 & 419 \\
& 60 & 463 \\
& 120 & 1295 \\
& 240 & 1435 \\
\hline \multirow{5}{*}{650} & 30 & 539 \\
& 60 & 1101 \\
& 120 & 2465 \\
& 240 & 3803 \\
\hline
\end{tabular}

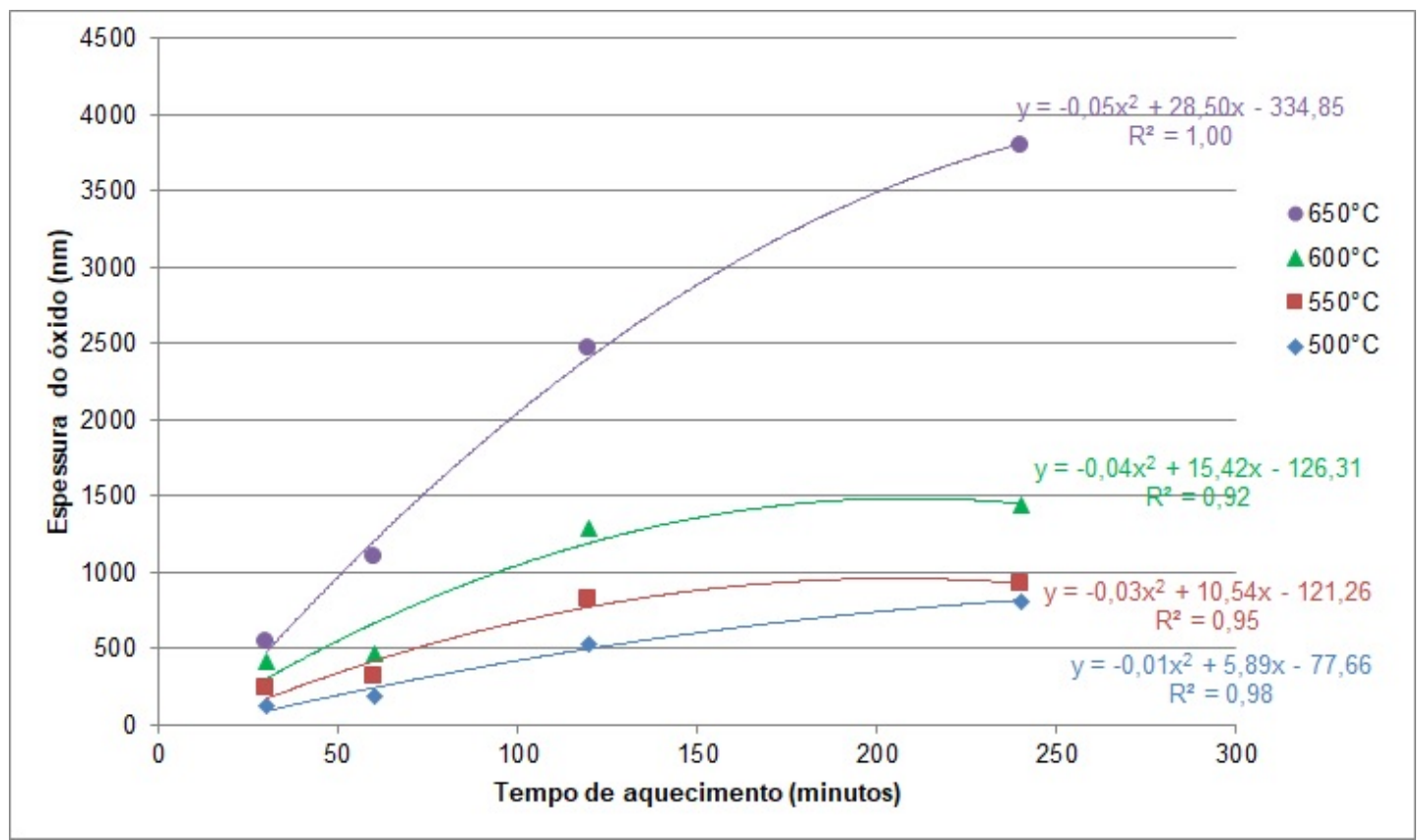

Figura 4.8: Curvas da evolução da espessura da camada de óxido sobre amostras polidas expostas a atmosfera oxidante em condições estáticas, em temperaturas de 500 a $650^{\circ} \mathrm{C}$, em função do tempo de aquecimento. Os pontos experimentais foram ajustados por curvas logarítmicas, cujas equações de ajuste são mostradas ao lado. 
Analisando as curvas, nota-se que as maiores espessuras de óxido são formadas às maiores temperaturas, porém o tempo também é um fator importante na cinética de crescimento da camada. Nas temperaturas $500^{\circ} \mathrm{C}$ e $550^{\circ} \mathrm{C}$, mesmo após 240 minutos de aquecimento, a camada de óxido tem menos de $1000 \mathrm{~nm}(1 \mu \mathrm{m})$ de espessura. Considerando-se uma relação exponencial entre a espessura de óxido e o tempo (uma vez que a oxidação é dada por difusão), pode-se extrapolar as curvas e supor que, à temperatura de $400^{\circ} \mathrm{C}$, a camada de óxido teria cerca de $100 \mathrm{~nm}$, o que pode ser considerado irrelevante. Assim, nos argumentos da Discussão (Seção 5), durante os ciclos térmicos aplicados nos ensaios de fadiga térmica, a oxidação será considerada apenas em temperaturas acima de $400^{\circ} \mathrm{C}$. 


\subsection{Cálculo de tensões}

Para o cálculo de tensões, realizado por modelagem por elementos finitos (MEF), foram levantadas as curvas do perfil de temperaturas no sentido radial, a fim de fornecer dados de entrada para o modelo. Essas curvas de temperatura vs. tempo, em cada profundidade, foram inseridas como entrada do modelo, além das condições: (1) Temperatura do ar: $20^{\circ} \mathrm{C}$; (2) Ar calmo; (3) Temperatura da água: $22^{\circ} \mathrm{C}$; (4) Temperatura da superfície interna, à profundidade $10 \mathrm{~mm}: 22^{\circ} \mathrm{C}$. Apesar da posição dos furos para inserção de termopares não ser alinhada verticalmente (Figura 3.5, pág. 82), para a construção do modelo bidimensional axissimétrico considerou-se que as medidas em profundidade representam toda a região àquela profundidade.

Os campos de temperatura importados em cada instante de tempo culminam em expansão e retração do material, conforme a Equação (2.2) (pág. 44). Estas deformações, conforme resposta elástica e elasto-plástica do material, estão associadas a tensões, também de origem térmica (Equação (2.5)), cujos efeitos no fenômeno de fadiga térmica são discutidos posteriormente nesse capítulo. É importante ressaltar que a evolução do campo de tensões associado ao campo de temperaturas leva em consideração a dependência das curvas de encruamento com a temperatura do material, mas não a recuperação de discordâncias.

Os perfis de temperatura foram coletados nas condições de ensaio REF $\left(600^{\circ} \mathrm{C}-20 \mathrm{~kW}\right)^{1}$, HOT $\left(650^{\circ} \mathrm{C}-20 \mathrm{~kW}\right)$ e LOW $\left(600^{\circ} \mathrm{C}-10 \mathrm{~kW}\right)$. Esses perfis são mostrados, respectivamente, na Figura 4.9, Figura 4.10 e Figura 4.11.

${ }^{1} \mathrm{~A}$ condição $\mathbf{R E F}$, quanto ao ciclo térmico, é igual à REV e ARG 


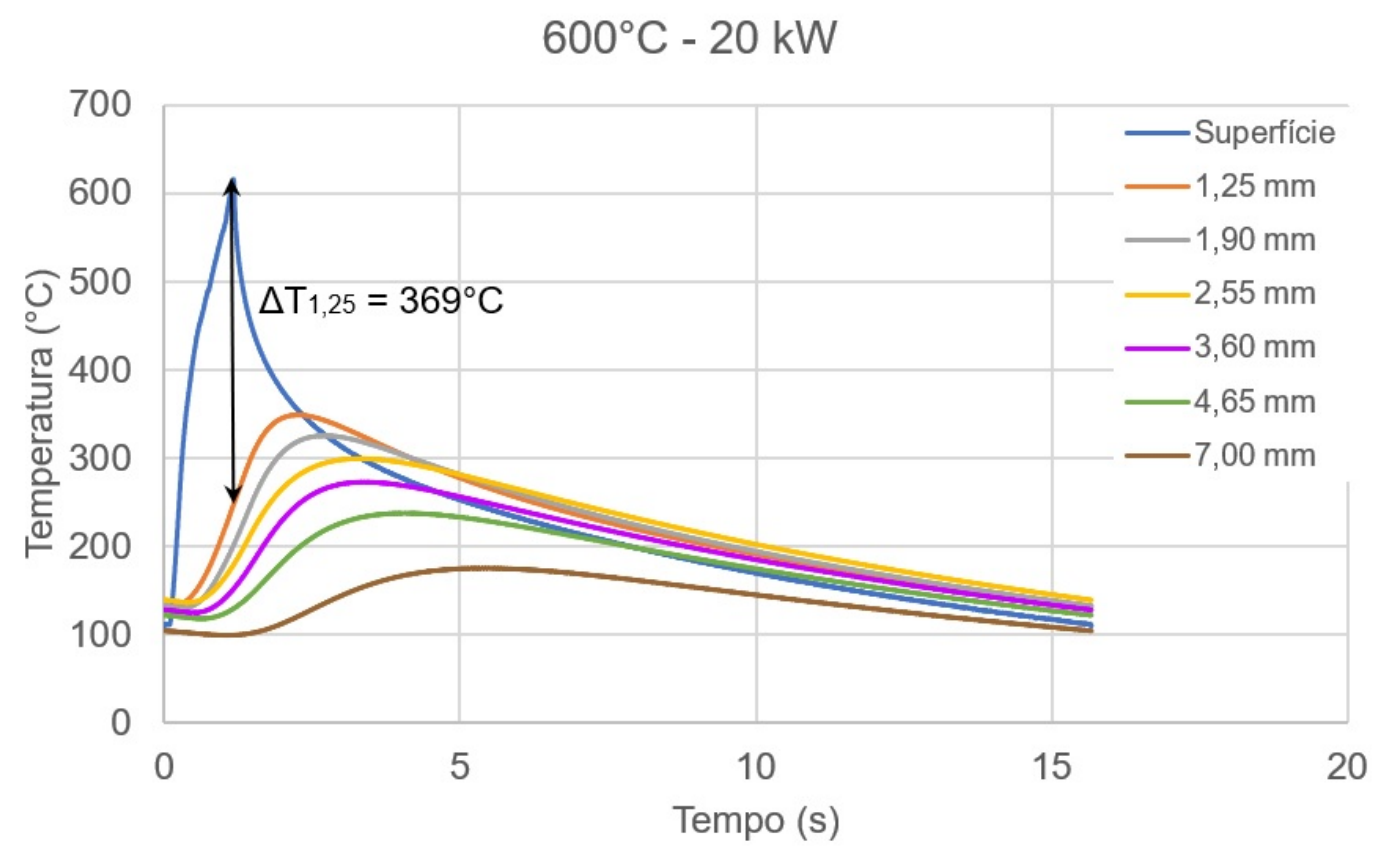

Figura 4.9: Perfil de temperaturas na direção transversal em 1 ciclo térmico, nas condições REF, REV e ARG.

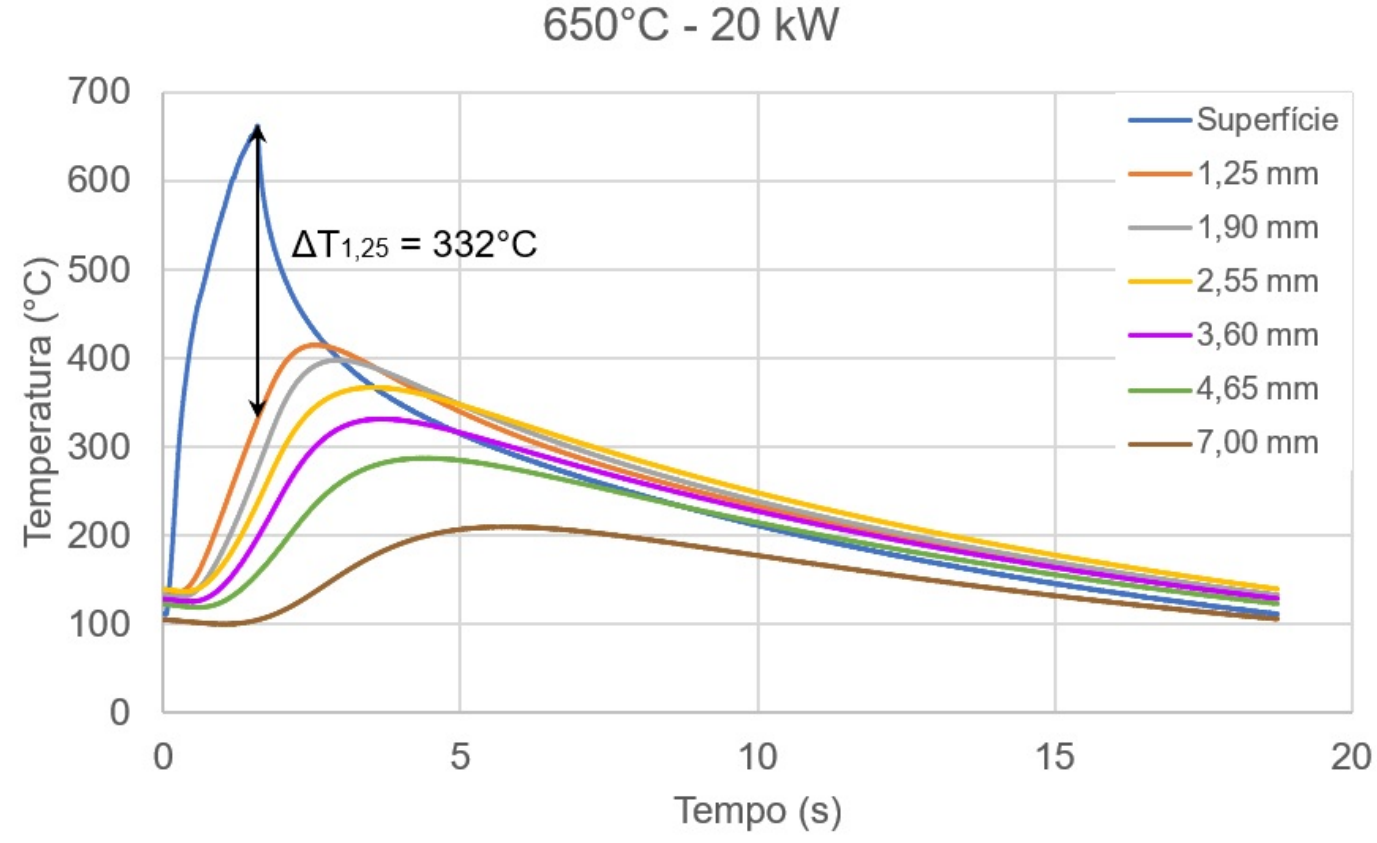

Figura 4.10: Perfil de temperaturas na direção transversal em 1 ciclo térmico, na condição HOT. 


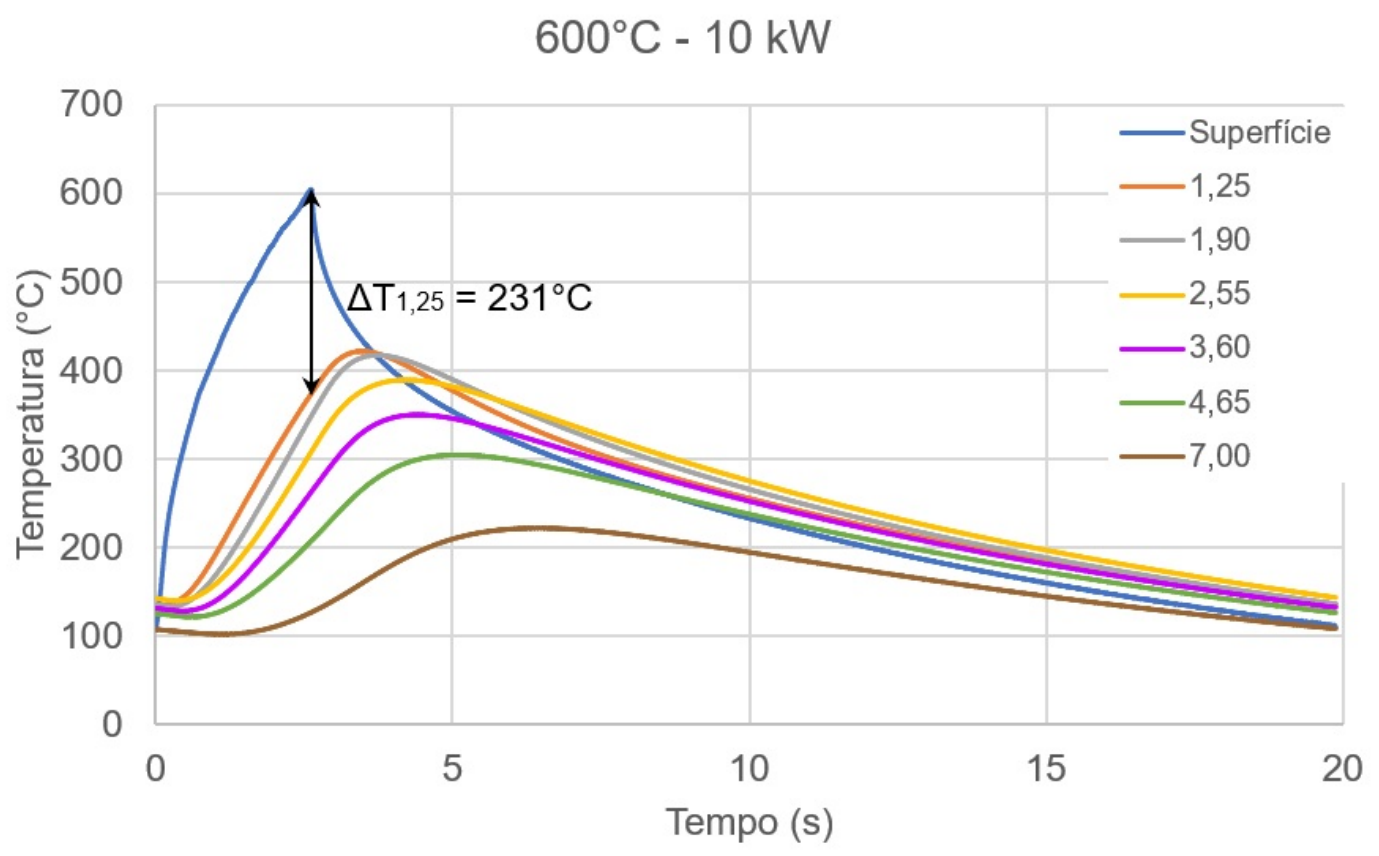

Figura 4.11: Perfil de temperaturas na direção transversal em 1 ciclo térmico, na condição LOW.

Analisando os perfis térmicos, é possível extrair as seguintes informações:

- O tempo de ciclo cresce na ordem REF < HOT < LOW.

- A diferença de temperatura entre a superfície e os pontos abaixo dela ao final do aquecimento cresce na ordem LOW < HOT < REF. Isso implica supor que a tensão causada pelo gradiente térmico na direção radial nesse ponto do ciclo térmico é menor na condição LOW e maior na condição REF.

- A diferença de temperaturas entre a superfície e as regiões abaixo dela dependem do tempo de aquecimento, uma vez que a alta condutividade térmica do material permite rápida distribuição de calor durante $o$ aquecimento.

- Por conta da rápida distribuição de calor durante o aquecimento, é imprudente supor que o maior gradiente térmico radial ocorre no final do aquecimento, pois ele pode acontecer antes.

- Durante o resfriamento, após algum tempo, a superfície deixa de ser a região mais quente e há uma inversão entre as curvas. Ao longo do tempo, outras inversões começam a acontecer até que, no final do resfriamento, o ponto mais quente está $2,55 \mathrm{~mm}$ abaixo da superfície. 
- Essa é uma informação importante para se manter em mente, porque as máximas temperaturas não estão sempre na superfície, apesar de aplicação de calor estar sendo feita apenas nos 50-100 $\mu \mathrm{m}$ externos.

- Coincidentemente, as máximas tensões também se deslocam para o interior do material.

- O ponto a 7,00 $\mathrm{mm}$ de profundidade é sempre a região mais fria e atinge, no máximo, $210^{\circ} \mathrm{C}$. A condição que proporciona maior aquecimento desse ponto é a LOW.

A partir de uma interpolação linear dos dados medidos de temperatura ao longo de um ciclo de aquecimento e resfriamento, foram construídos os mapas de contorno em função da temperatura no software MATLAB ${ }^{\circledR}$ (Figura 4.12). Desta forma, é possível visualizar com mais facilidade a região do corpo de prova que é exposta a alta temperatura e por quanto tempo. Há uma anomalia nos mapas na região do resfriamento na profundidade de $2,55 \mathrm{~mm}$, que foi gerada pela baixa capacidade de arredondamento das curvas por interpolação linear entre esses dados e os vizinhos, das profundidades 1,90 e 3,60 mm.

A comparação mais simples que pode ser feita entre as figuras é em relação à área do gráfico correspondente a temperaturas mais altas. Se observarmos as áreas nas cores verde, amarela, laranja e vermelha (correspondende a temperaturas acima de $350^{\circ} \mathrm{C}$ ), a Figura 4.12a está restrita a uma área razoavelmente menor que na Figura $\mathbf{4 . 1 2 b}$, que, por sua vez, é menor que a Figura 4.12c. Isso significa que nas condições HOT e LOW o material passa mais tempo exposto a altas temperaturas, e em uma espessura maior, o que implica dizer que as propriedades mecânicas do material são afetadas por uma maior espessura nessas duas condições de ciclo térmico. Isso pode estar relacionado a uma camada revenida mais espessa e menores propriedades mecânicas na região de nucleação e propagação inicial das trincas de fadiga térmica durante os ciclos. Esse comportamento foi previsto no planejamento do trabalho, como foi dito na Seção 3.1.

É importante observar a diferença de temperatura entre a superfície interna (depth=10 mm), no furo por onde passa água, e o interior do material. Nessa região fria, a dureza do material é máxima e a tenacidade é mínima, portanto gradientes térmicos nessa área são indesejáveis. Visto dessa forma, o ciclo térmico da condição LOW é o mais provável para nucleação de trincas na face interna dos corpos de prova. 


\subsubsection{Modelamento por Elementos Finitos}

As tensões calculadas na direção axial ao longo do ciclo térmico são mostradas na Figura 4.13, para os três ciclos térmicos utilizados. No centro do corpo de prova, as tensões axial e circunferencial são praticamente idênticas, o que se confirma pela forma quadrada da malha de trincas, enquanto a tensão radial é teoricamente zero, em decorrência da resistência à expansão térmica, que não ocorre na direção radial, cuja superfície é livre (Seção 2.4.2). Medjedoub $^{[3]}$ explicou com detalhes a influência do estado de tensões e da forma da malha de trincas térmicas, reforçando o argumento anterior.

Na Figura 4.13, acompanhando a linha correspondente a uma das condições de ensaio, nota-se que, com exceção primeiro ciclo, as tensões e deformações variam dentro de um ciclo de histerese. Considerando que os corpos de prova estejam inicialmente descarregados, as linhas saem da origem do gráfico no primeiro ciclo de aquecimento para a região de tensões negativas (compressão). A tensão máxima é diferente para cada condição de temperatura e velocidade de aquecimento. Quando o aquecimento termina, as propriedades mecânicas do material são significativamente menores, devido à alta temperatura, ao mesmo tempo em que as tensões originadas pela restrição à dilatação térmica são bastante elevadas. Consequentemente, ocorre deformação plástica intensa, somando-se à deformação elástica, que acontece o tempo todo, mesmo durante o regime plástico. A deformação plástica gerada pela condição HOT é significativamente maior que a condição REF, que é pouco maior que a da condição LOW.

Quando se inicia o resfriamento, devido à mudança de forma do material causada pela deformação plástica, as tensões não são descarregadas pelo caminho do carregamento, mas sim de forma elástica. Elas se tornam trativas e atingem o limite de escoamento em tração antes que a deformação direcional tenha retornado a zero, por conta do efeito Bauschinger (Figura 4.14). Esse fenômeno ocorre em alguns materiais metálicos submetidos a carregamento cíclico, quando o limite de escoamento for excedido já no primeiro carregamento. Nesse caso, sob solicitações na direção oposta, o escoamento do material iniciará já a uma tensão menor, dada por $\sigma_{y}^{\prime \prime}=\sigma_{y}^{\prime}-2 \sigma_{y}$. Ao final do resfriamento, o ciclo seguinte não começa mais da origem, mas de um novo ponto com deformações e tensões não nulas.

Essa "translação" da curva no plano tensão-deformação ocorre a cada novo ciclo, com magnitude reduzida até que se atinja um regime permanente, 
em que a cada novo ciclo térmico a curva tensão-deformação cíclica passa a percorrer sempre o mesmo caminho (completando um ciclo de histerese). Uma característica dessa histerese é que ocorre deformação plástica tanto em compressão como em tração a cada ciclo, carregamento de fadiga de baixo ciclo similar a dobrar sucessivas vezes um clipe de papel, por exemplo.

Note na Figura 4.13 que, durante o primeiro aquecimento, as tensões das condições REF e HOT são idênticas, porque a velocidade de aquecimento é igual. Quando, na condição REF o aquecimento termina, a curva da condição HOT prossegue até atingir deformação plástica maior. A partir de então, as duas curvas seguem separadas. O efeito Bauschinger, que é a alteração do limite de escoamento causado pela deformação plástica, é mais proeminente na condição HOT, que teve a maior deformação plástica. Por outro lado, como as tensões geradas pelo aquecimento e resfriamento da condição LOW são menores que em REF, também diminui o escoamento nos ciclos seguintes, porque a aplicação de tensão é insuficiente para gerar a mesma deformação plástica. 


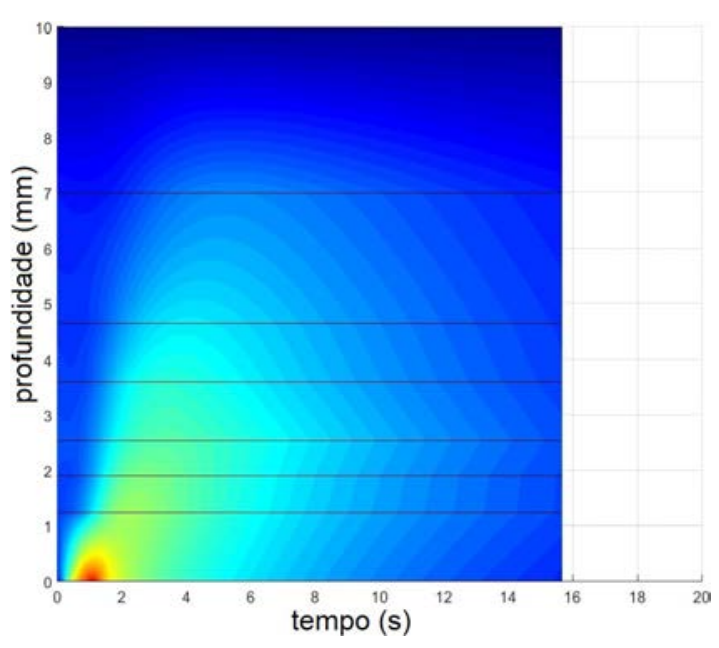

(a)

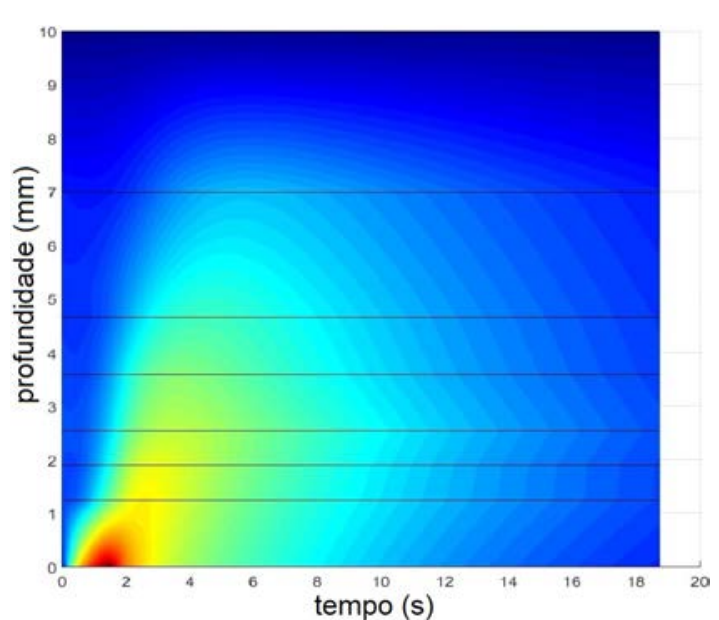

(b)

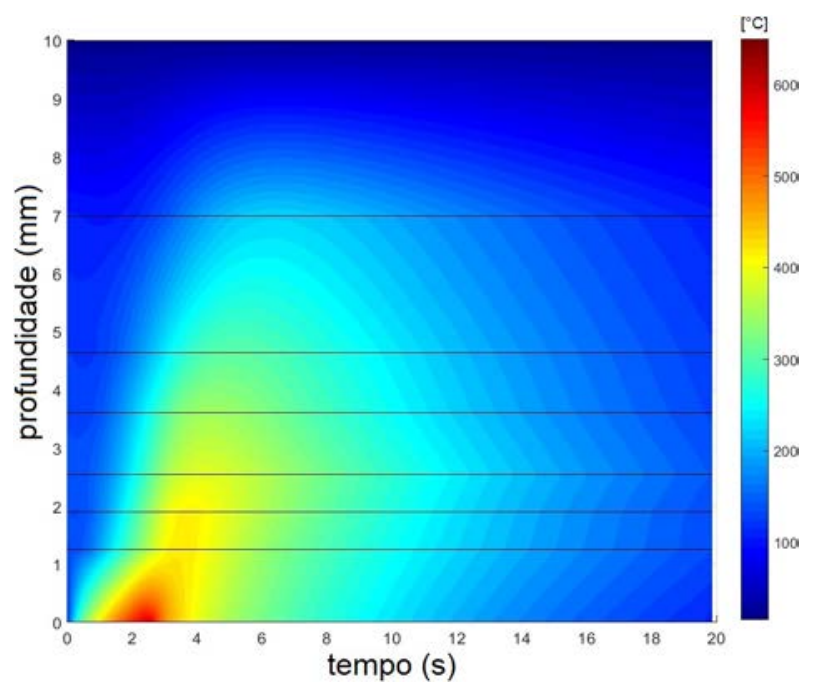

(c)

Figura 4.12: Mapas de contorno de temperatura em função do tempo e da distância à superfície do corpo de prova. A escala de cores indica a temperatura, de 15 a $650^{\circ} \mathrm{C}$; o tempo time=0 s é o início do aquecimento; a posição depth $=0 \mathrm{~mm}$ é a superfície externa e depth $=10 \mathrm{~mm}$ é a superfície interna do furo, com temperatura constante igual a $18,8^{\circ} \mathrm{C}$. (a) Condição REF, REV e ARG, $T_{\max }=600^{\circ} \mathrm{C}$, Potência $=20 \mathrm{~kW}$; (b) Condição HOT, $T_{\max }=650^{\circ} \mathrm{C}$, Potência $=20 \mathrm{~kW}$; (c) Condição LOW, $T_{\max }=600^{\circ} \mathrm{C}$, Potência $=10 \mathrm{~kW}$. 


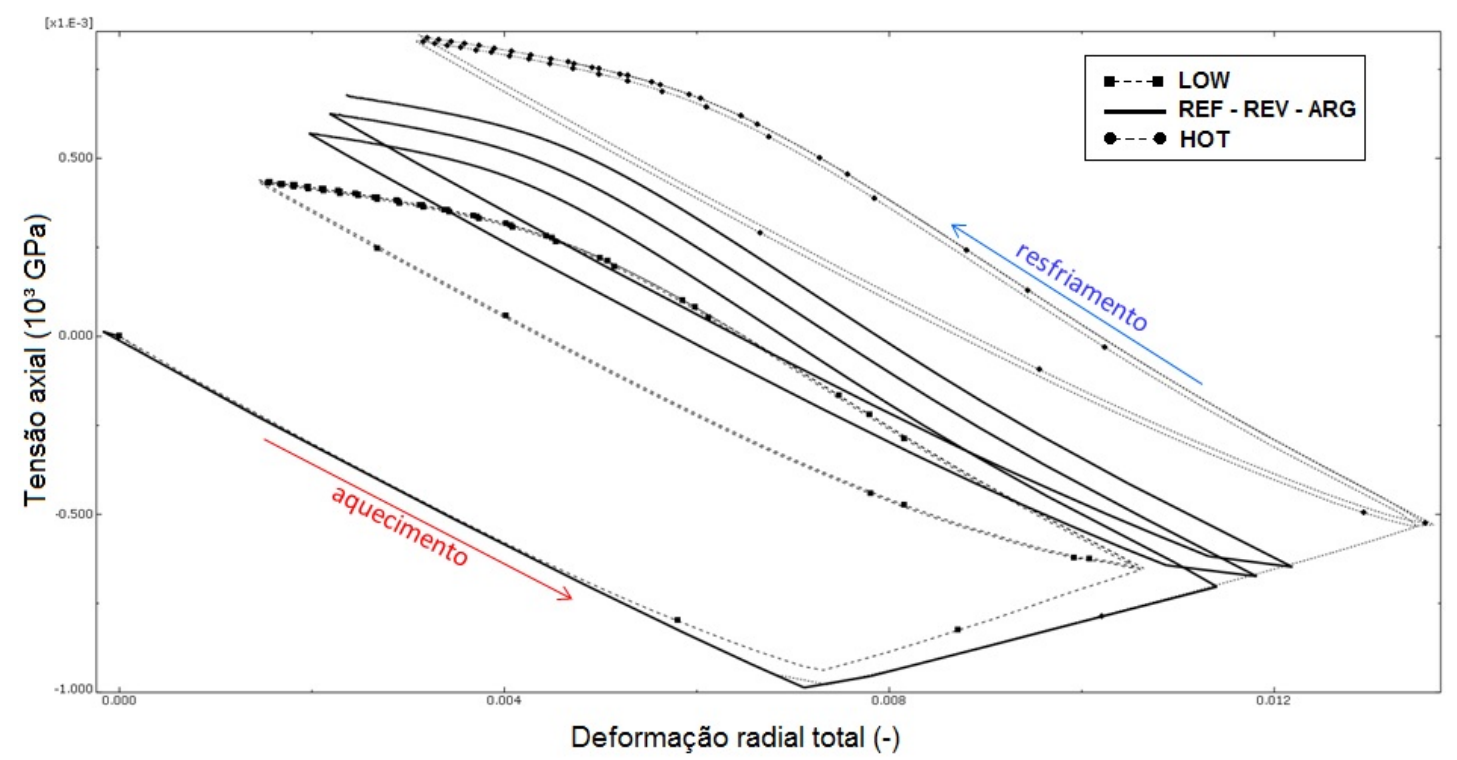

Figura 4.13: Curvas de tensão na superfície calculadas durante os 3 primeiros ciclos de fadiga térmica nas condições REF, HOT e LOW (histerese). As características do carregamento geram deformação plástica em compressão e em tração, típicas de fadiga de baixo ciclo.

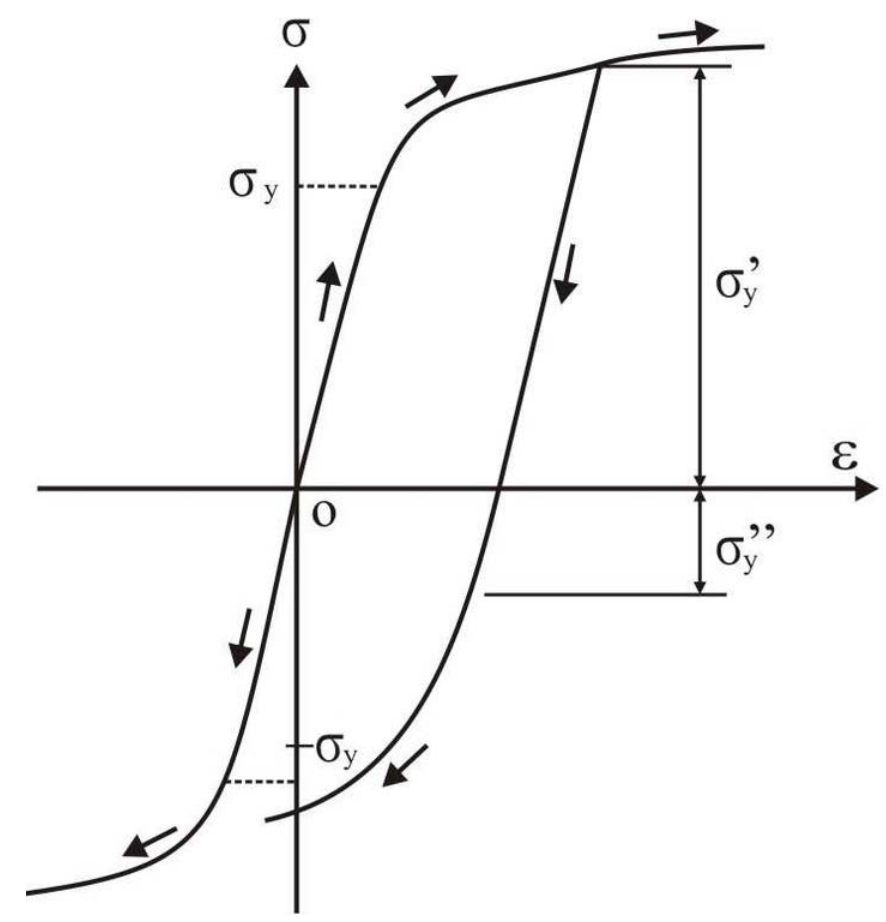

Figura 4.14: Representação das curvas de tensão-deformação durante um ciclo de carregamento com efeito Bauschinger ${ }^{[69]}$. Após o final do primeiro carregamento com presença de deformação plástica, no carregamento reverso ocorre plasticidade em tensão de escoamento de módulo menor que a inicial. 


\subsubsection{Modelos 2D}

Como resultado do cálculo de distribuição de temperaturas ao longo dos ciclos térmicos, podem ser comparadas também as distribuições de tensões nos corpos de prova. As figuras 4.15, 4.16 e 4.17 foram geradas após o cálculo da evolução de tensões nas direções radial (S11 - esquerda), axial (S22 centro) e circunferencial (S33 - direita), em 4 tempos distintos: (1) na metade do aquecimento; (2) no final do aquecimento; (3) na metade do resfriamento; e (4) no final do resfriamento, que coincide com o início do aquecimento do ciclo seguinte.

Os pontos que indicam alta tensão calculada na região do pescoço podem ser desconsiderados, pois o modelo pode ter previsto uma região de aquecimento do corpo de prova mais larga que a real, que não pôde ser verificada experimentalmente, mas foi calculada durante o projeto da bobina (pág. 87). Entretanto, esse resultado explica por que os corpos de prova constantemente fraturavam nessa região quando ensaiados com a primeira versão da bobina, esta sim que possuía um enrolamento em ângulo que favorecia o aquecimento próximo à região do pescoço do corpo de prova.

Em todas as condições de aquecimento, a situação de maiores tensões, em módulo, na superfície externa, é a metade do aquecimento. As tensões axiais e circunferenciais chegam próximas a -1000 MPa (compressão). Na superfície interna, as tensões são máximas no final do aquecimento e, na condição LOW a tensão radial chega próxima de +800 MPa (tração). No resfriamento, a superfície fica sob tensões de tração de cerca de +500 MPa. O limite de escoamento medido para a matriz a $500^{\circ} \mathrm{C}$ é $1102 \mathrm{GPa}$, o que faz supor que, a $600^{\circ} \mathrm{C}$, a tensão possa seja suficiente para causar deformação plástica ${ }^{1}$. É possível comprovar, por exemplo na Figura 4.15, direção axial, $t=1,1 \mathrm{~s}$, pela forma da região comprimida, que o ponto de maiores tensões não está necessariamente na superfície, como foi suposto anteriormente nesta seção.

As tensões compressivas no aquecimento geradas nas condições REF e HOT são semelhantes porém, na condição HOT, desenvolvem-se tensões trativas maiores na superfície externa durante o resfriamento. Já na região interna, as tensões trativas geradas no resfriamento nas condições HOT e LOW são semelhantes, porém atingem uma área mais extensa em LOW.

\footnotetext{
${ }^{1}$ Convém lembrar que o escoamento é dado por estado triaxial de tensões, portanto, um valor alto de tensões pode não ser suficiente para causar deformação plástica.
} 


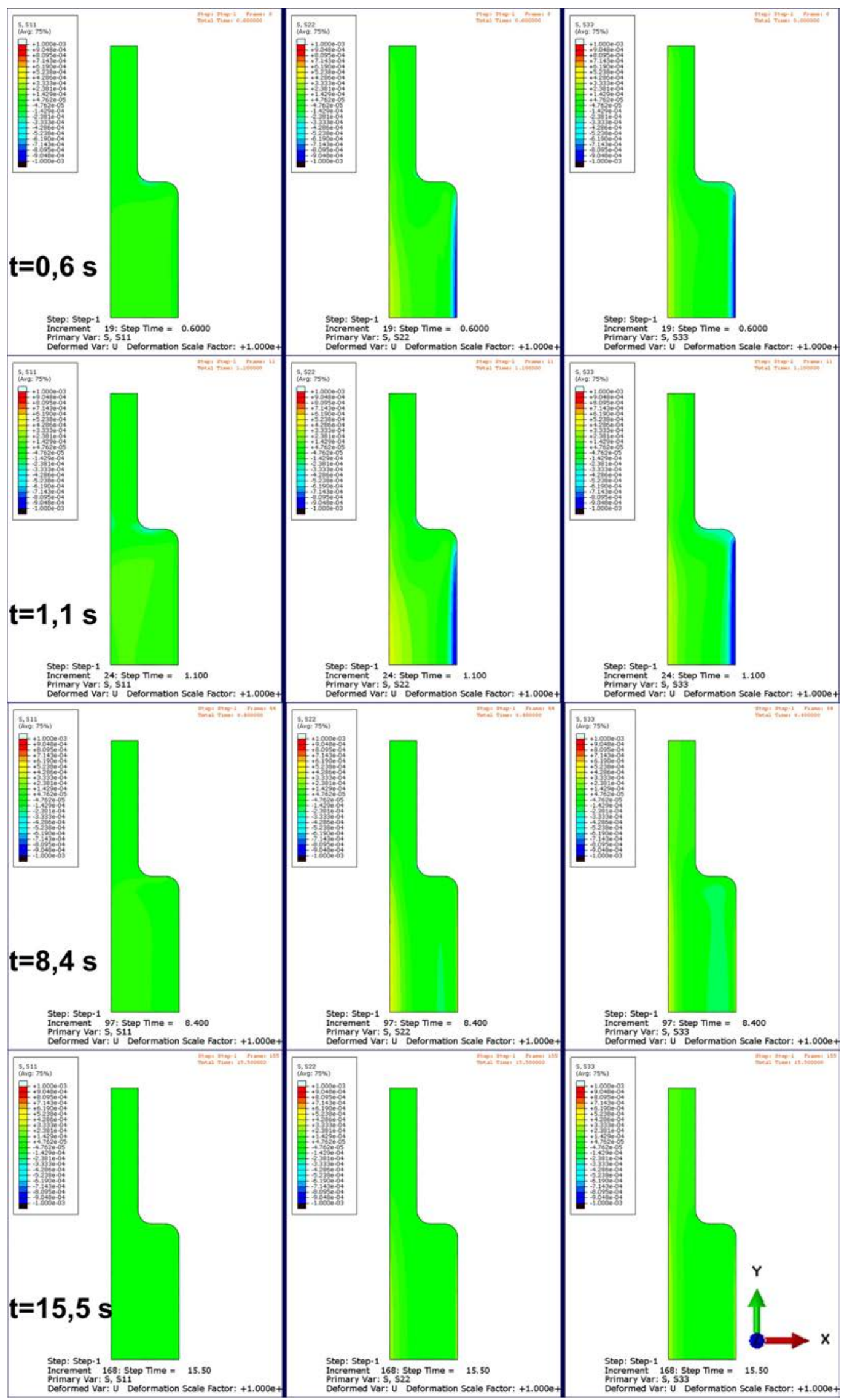

Figura 4.15: Distribuição de tensões (GPa) no corpo de prova aquecido na condição REF, calculadas por MEF, nas direções radial (S11 - esquerda), axial (S22 - centro) e circunferencial (S33 - direita), em 4 tempos distintos: na metade do aquecimento, no final do aquecimento, na metade do resfriamento e no final do resfriamento, que coincide com o início do aquecimento do ciclo seguinte. Escala: -1 a $1 \mathrm{GPa}$. 


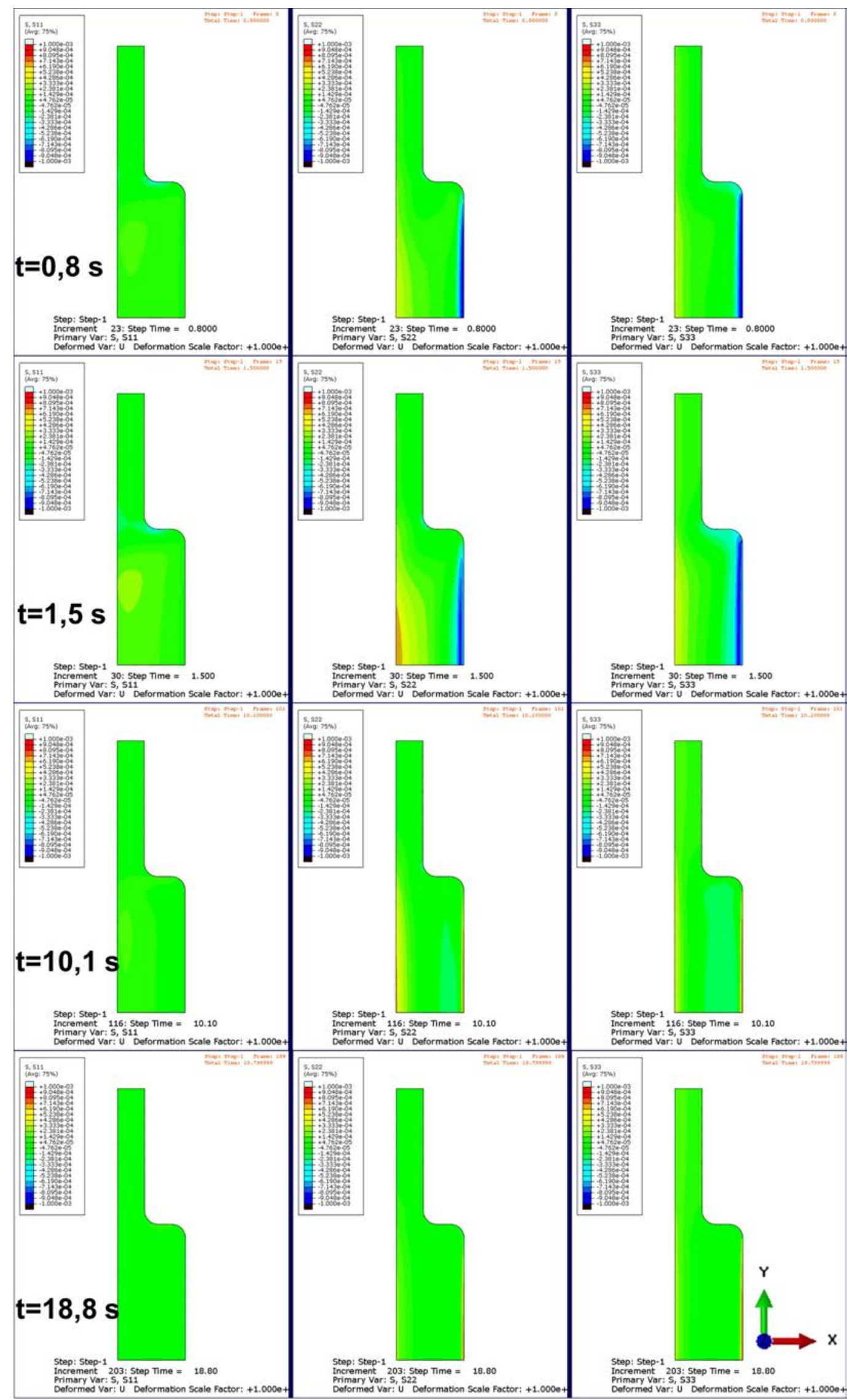

Figura 4.16: Distribuição de tensões (GPa) no corpo de prova aquecido na condição HOT, calculadas por MEF, nas direções radial (S11 - esquerda), axial (S22 - centro) e circunferencial (S33 - direita), em 4 tempos distintos: na metade do aquecimento, no final do aquecimento, na metade do resfriamento e no final do resfriamento, que coincide com o início do aquecimento do ciclo seguinte. Escala: -1 a $1 \mathrm{GPa}$. 


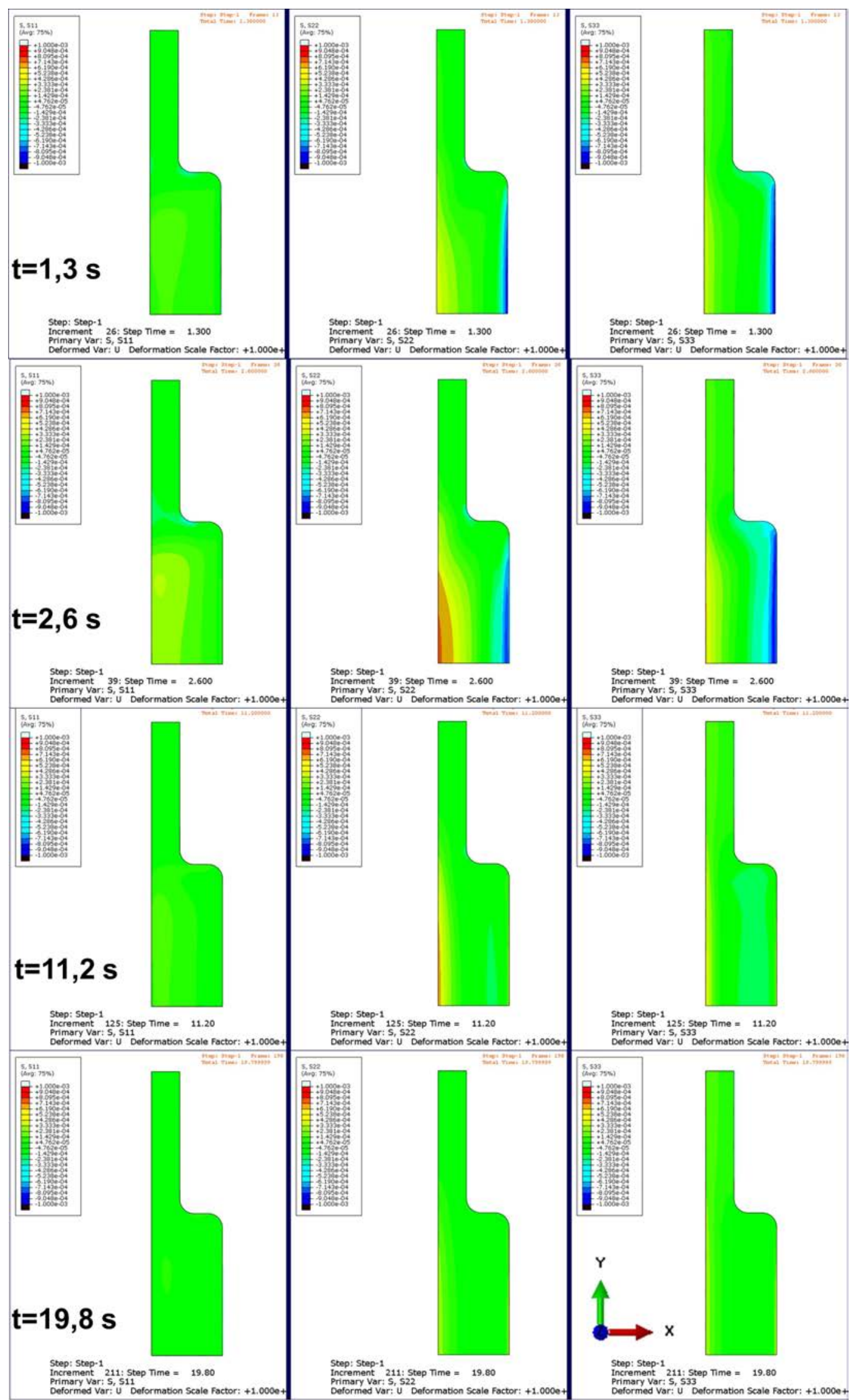

Figura 4.17: Distribuição de tensões (GPa) no corpo de prova aquecido na condição LOW, calculadas por MEF, nas direções radial (S11 - esquerda), axial (S22 - centro) e circunferencial (S33 - direita). A primeira linha mostra as tensões na metade do aquecimento. As seguintes mostram: no final do aquecimento, na metade do resfriamento e no final do resfriamento, que coincide com o início do aquecimento do ciclo seguinte. Escala: -1 a $1 \mathrm{GPa}$. 


\subsection{Fadiga térmica}

Para facilitar a construção do raciocínio sobre os mecanismos de nucleação de trincas de fadiga térmica em aços ferramenta com carbonetos $\mathrm{NbC}$, esta seção será dividida em 4 partes:

1. Ensaios preliminares

2. Ensaios de fadiga térmica

3. Caracterização da seção transversal

4. Tomografia de raios- $X$ 


\subsubsection{Observações preliminares da morfologia das malhas de trincas térmicas}

Após alguns ciclos de aquecimento e resfriamento, segundo o que se observa no microscópio óptico, a superfície dos corpos de prova oxida, formando uma camada de óxidos que trinca a partir dos carbonetos. Essas trincas são as chamadas trincas secundárias e são restritas à camada de óxido. As trincas secundárias propagam em direção a outros carbonetos, até se conectarem, enquanto novas trincas se multiplicam, aumentando a densidade de trincas na região entre os carbonetos, até atingir a densidade de trincas estável. Esse padrão de trincas formadas é chamado na literatura de heat checking, porque se assemelha a um tabuleiro de xadrez formado pelas trincas. A Figura 4.18 mostra as medidas de densidade de trincas realizadas a cada 1000 ciclos. A Figura 4.19 demonstra esse mecanismo que foi descrito em um corpo de prova ensaiado até $550^{\circ} \mathrm{C}$ (bobina 1), com velocidade alta de aquecimento, até 15000 ciclos.

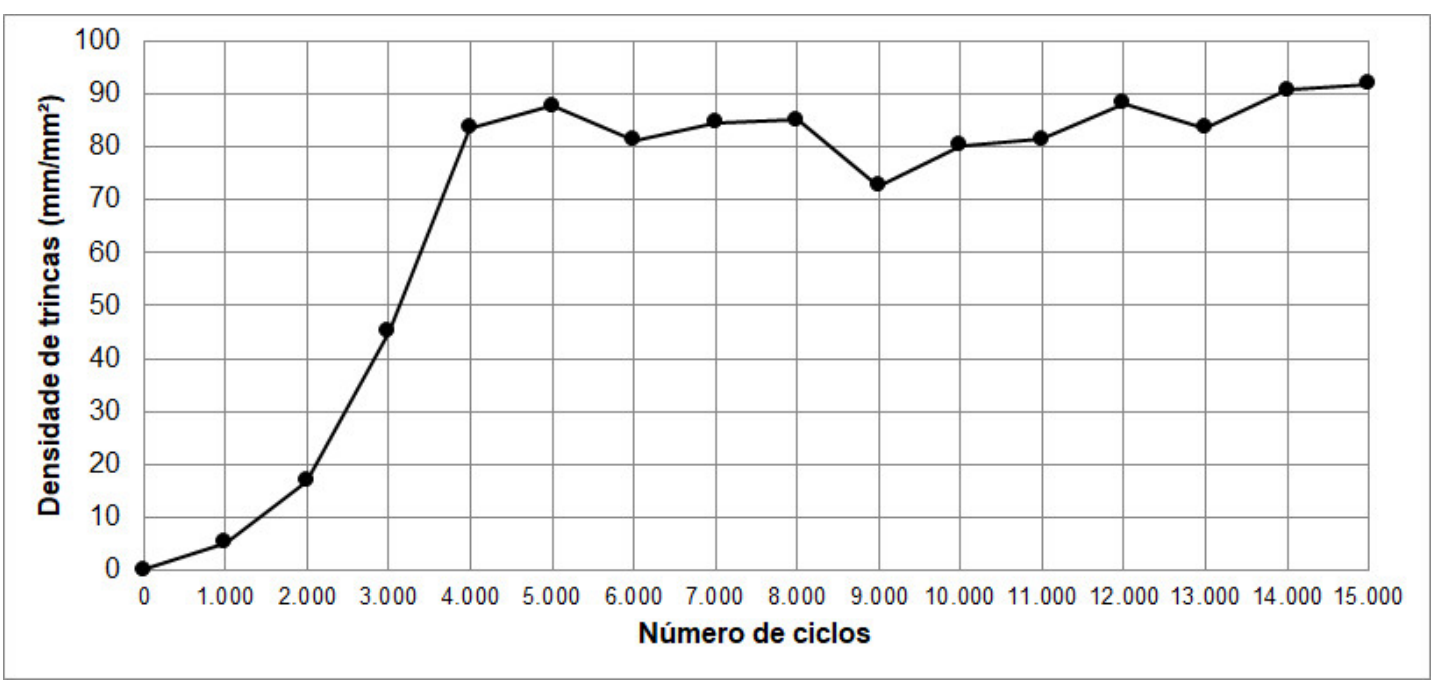

Figura 4.18: Evolução da densidade de trincas em um corpo de prova ensaiado até $550^{\circ} \mathrm{C}$, com velocidade alta de aquecimento, até 15000 ciclos. As trincas surgem antes de 1000 ciclos e atingem uma densidade estável aos 4000 ciclos. 


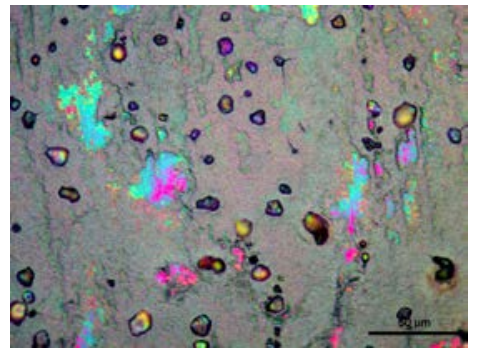

(a)

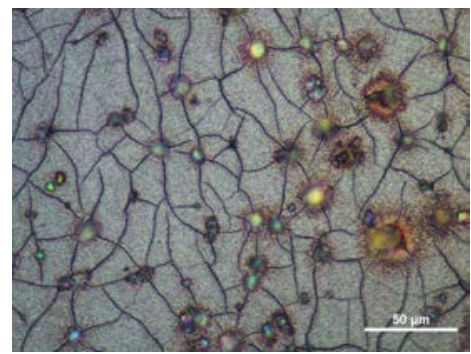

(d)

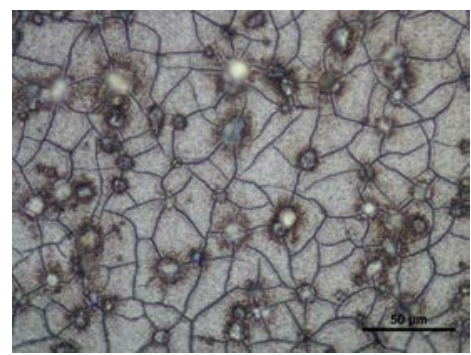

(g)

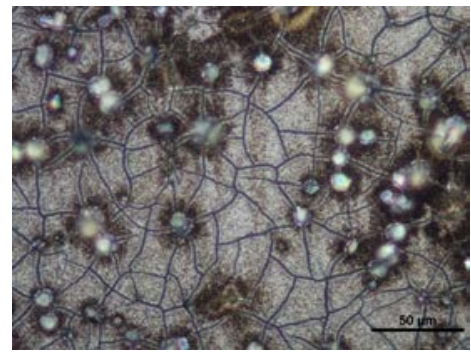

(j)

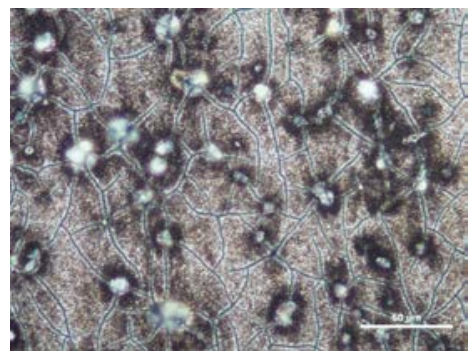

(m)

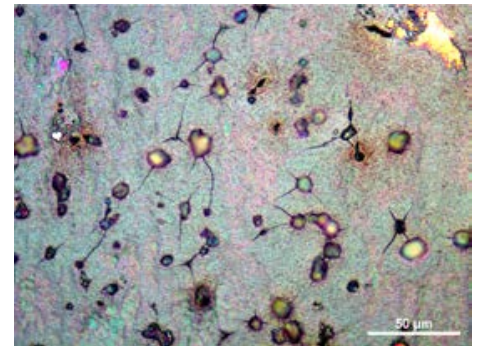

(b)

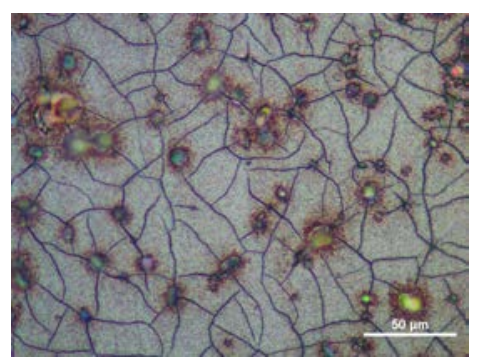

(e)

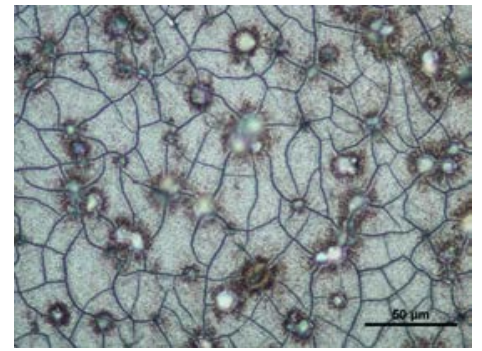

(h)

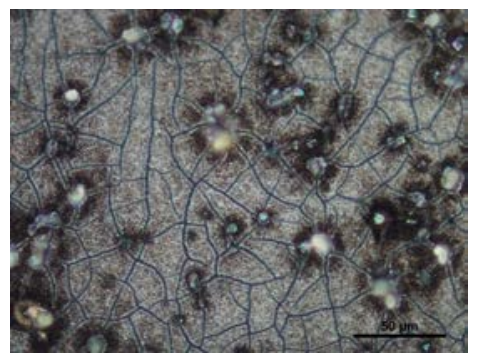

(k)

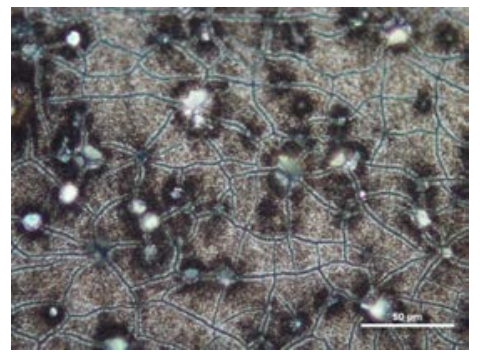

(n)

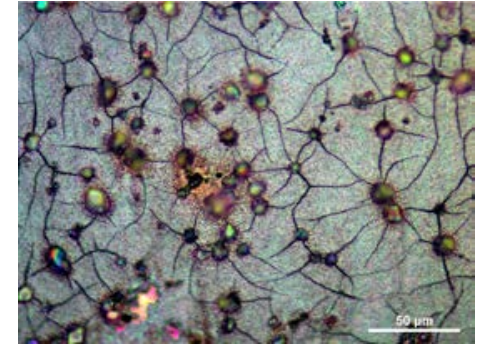

(c)

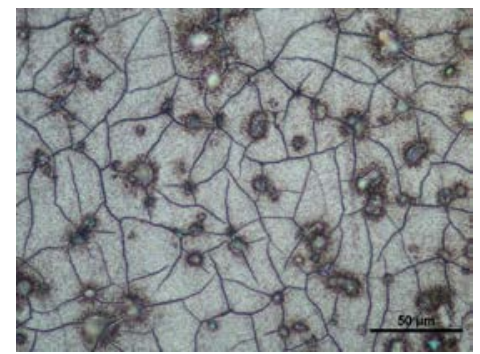

(f)

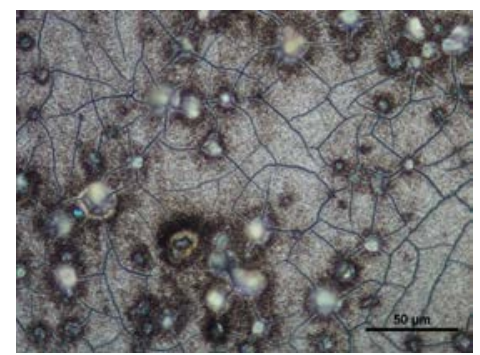

(i)

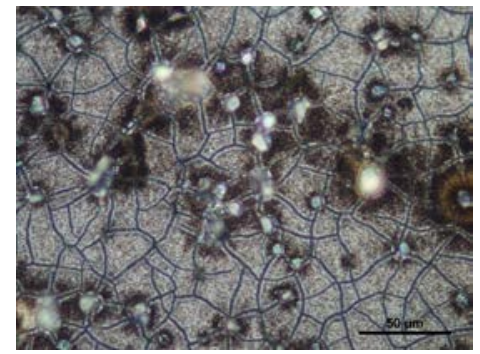

(I)

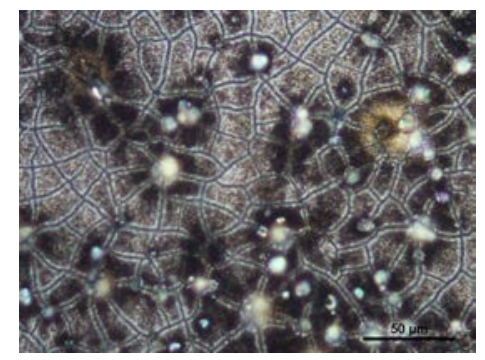

(o)

Figura 4.19: Evolução da densidade de trincas em um corpo de prova ensaiado até $550^{\circ} \mathrm{C}$, com velocidade alta de aquecimento. (a) 1000 ciclos; (b) 2000; (c) 3000; (d) 4000; (e) 5000; (f) 6000; (g) 7000; (h) 8000; (i) 9000; (j) 10000; (k) 11000; (l) 12000; (m) 13000; (n) 14000; (o) 15000. 
Ao final do ensaio, no fim da vida do material, trincas macroscópicas nucleiam e/ou afloram na superfície, causando vazamento de água. A Figura 4.20 mostra dois casos de macrotrincas, também chamadas de trincas primárias. Na Figura 4.20a, houve vazamento de água e contaminação da superfície, que teve formação de óxido avermelhado. Na Figura 4.20b, pode-se ver como a trinca primária propaga segundo a forma da trajetória das trincas secundárias, que já estavam presentes no material. Ocasionalmente, essas trincas primárias podem mudar de direção dentro do material e se conectar, causando arrancamentos e gerando perda de massa.

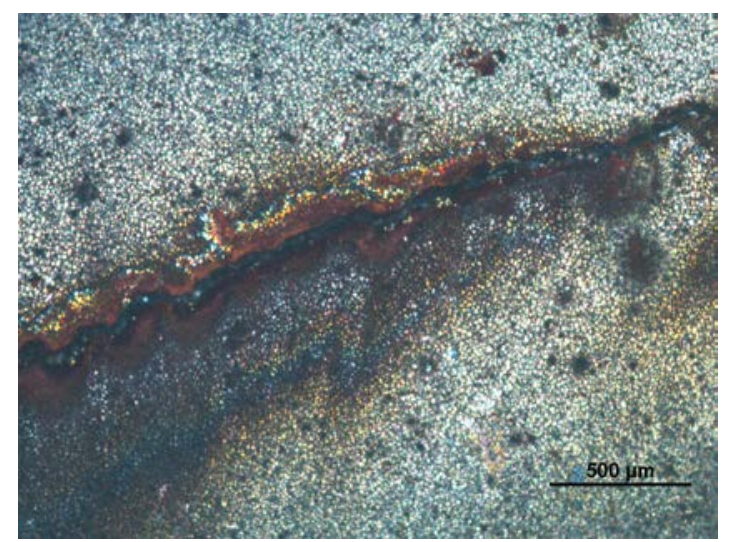

(a)

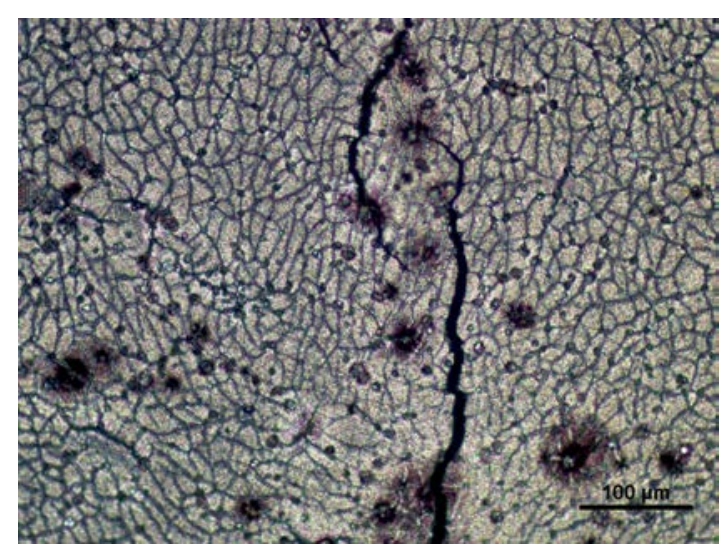

(b)

Figura 4.20: Trincas primárias (macrotrincas) formadas durante ensaios de fadiga térmica, causando vazamento de água e perda de massa. (a) Trinca primária por onde houve vazamento de água, manchando a superfície com óxido avermelhado; (b) Detalhe de duas trincas primárias propagando-se através da malha de trincas secundárias, próximas de se conectarem.

Após o ensaio, outro corpo de prova ensaiado a $550^{\circ} \mathrm{C}$ por 5000 ciclos (condição REF) foi cortado ao meio e a face transversal foi lixada e polida para observação em microscópio eletrônico de varredura (MEV). A amostra foi preparada sem embutimento, para permitir a visualização tanto da seção transversal quanto da superfície ensaiada. $O$ objetivo foi relacionar a malha de trincas que vinha sendo observada na superfície com a morfologia e profundidade das trincas propagando para dentro do material. A observação da amostra foi feita no MEV-FEG, com imagem de elétrons secundários e elétrons retroespalhados. A Figura 4.21 mostra as imagens de elétrons secundários obtidas da superfície da amostra, em ângulo. Observa-se a superfície porosa devido à oxidação. Pode-se notar que a região das trincas está em mais alto relevo que a região não trincada, o que indica oxidação diferente na região das trincas. Também é nítido o acúmulo de óxidos sobre os carbonetos que estão na superfície, que ficam parecendo pequenas aberturas de vulcão. 


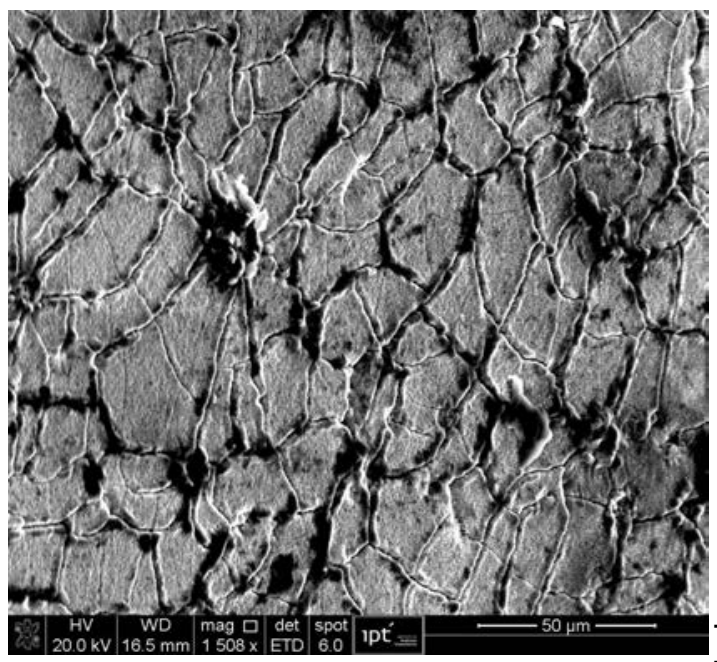

(a)

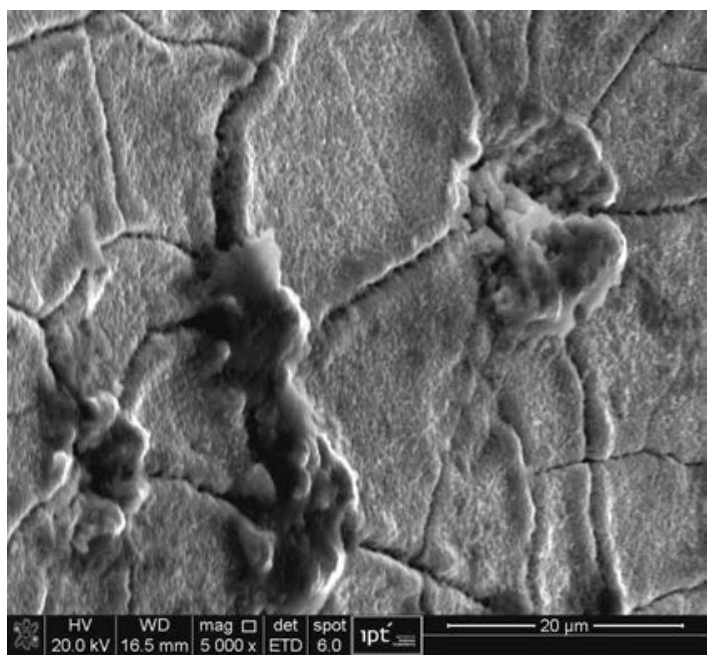

(b)

Figura 4.21: Imagens (MEV) da superfície do corpo de prova após ensaio de fadiga térmica, vista em ângulo $15^{\circ}$. Elétrons secundários. (a) Aumento 1500x, mostrando o relevo formado nas regiões de trincas e de carbonetos.

(b) Detalhe região, com aumento 5000x, mostrando a camada de óxido porosa e a região sobre os carbonetos e ao redor das trincas.

Ao observar a região da superfície na seção transversal (Figura 4.22), houve uma surpresa. A superfície estava coberta por uma camada aderente e uniforme de óxido, com trincas que não propagaram para o interior da amostra, como era esperado. Ao contrário, o óxido parece ter sido regenerado ao longo do ensaio, recuperando a trinca.

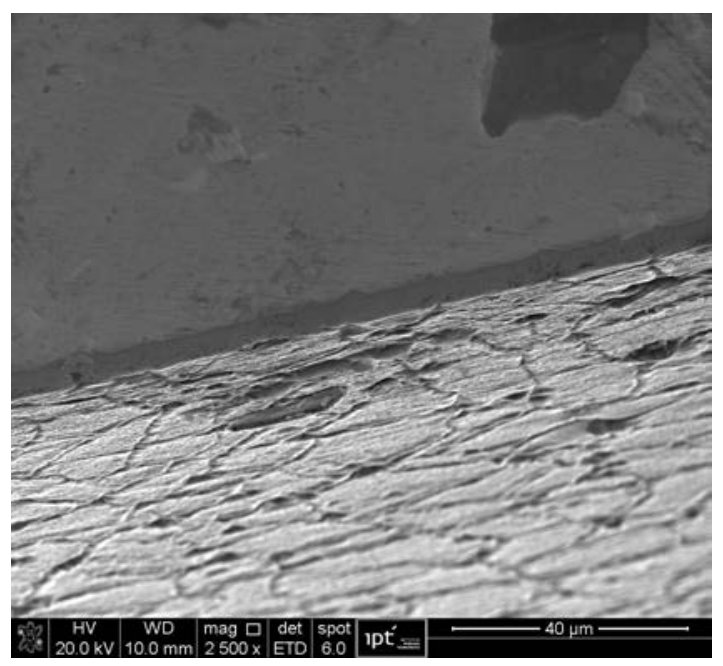

(a)

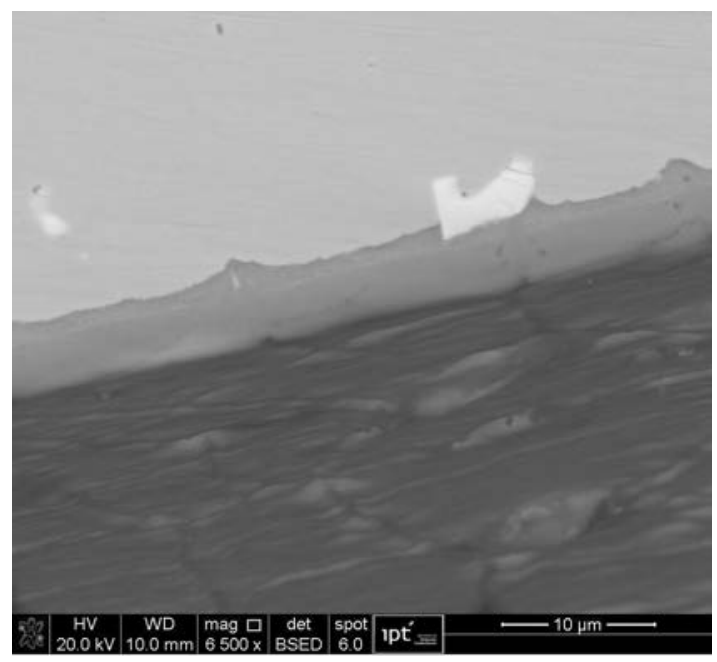

(b)

Figura 4.22: Imagens (MEV) da região de canto entre superfície e seção transversal polida do corpo de prova após ensaio de 5000 na condição REF.

(a) Pontos de oxidação preferencial em forma de $V$ coincidentes com as trincas da camada de óxido. Não há trincas propagando para a matriz; (b) Detalhe, mostrando a formação de 2 camadas de óxidos, sendo uma delas de espessura uniforme e a outra, próxima ao metal, com pontos de profusão sobre a matriz em forma de V. 
Em toda a borda da seção transversal, não foi localizada nenhuma trinca propagando para a matriz, nem mesmo nos óxidos. O que se viu, no entanto, foram algumas reentrâncias em forma de $\mathbf{V}$ logo abaixo das regiões de trincas superficiais do óxido e próximas aos carbonetos. A espessura média do óxido sobre a matriz é de $4,1 \mu \mathrm{m}$. Nas reentrâncias, a espessura de óxido é de $5,4 \mu \mathrm{m}$. Esses Vs podem ser vistos em diferentes estágios na Figura 4.23, desde a formação do $\mathbf{V}$ até a oxidação mais profunda, com uma trinca central. No centro da trinca nota-se a formação de uma fina camada de outro óxido, mais claro que o óxido formado nas regiões íntegras. Quando olhadas no microscópio óptico com ataque Nital 2\% (Figura 4.24), essas formações de óxido em forma de $\mathbf{V}$ revelam estar preferencialmente em interfaces carboneto/matriz e em contornos de grão da matriz.

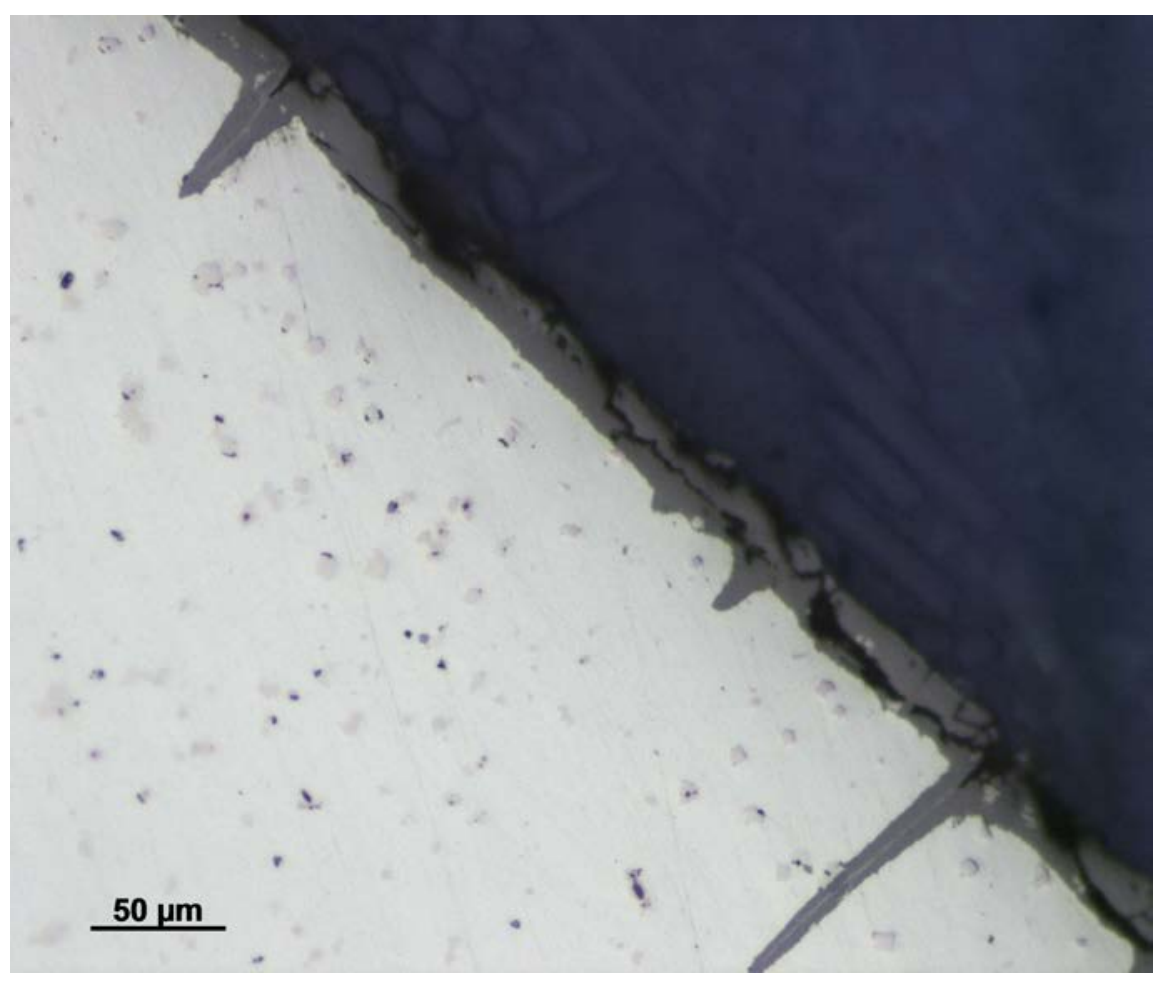

Figura 4.23: Pontos de oxidação preferencial formados durante ensaio de fadiga térmica, em diferentes estágios. Pode ser visto um ponto inicial, com a formação do $\mathbf{V}$, outro intermediário e dois outros (extremidades) mais avançados, que estão trincados e com a formação de um óxido mais claro no interior da trinca. 


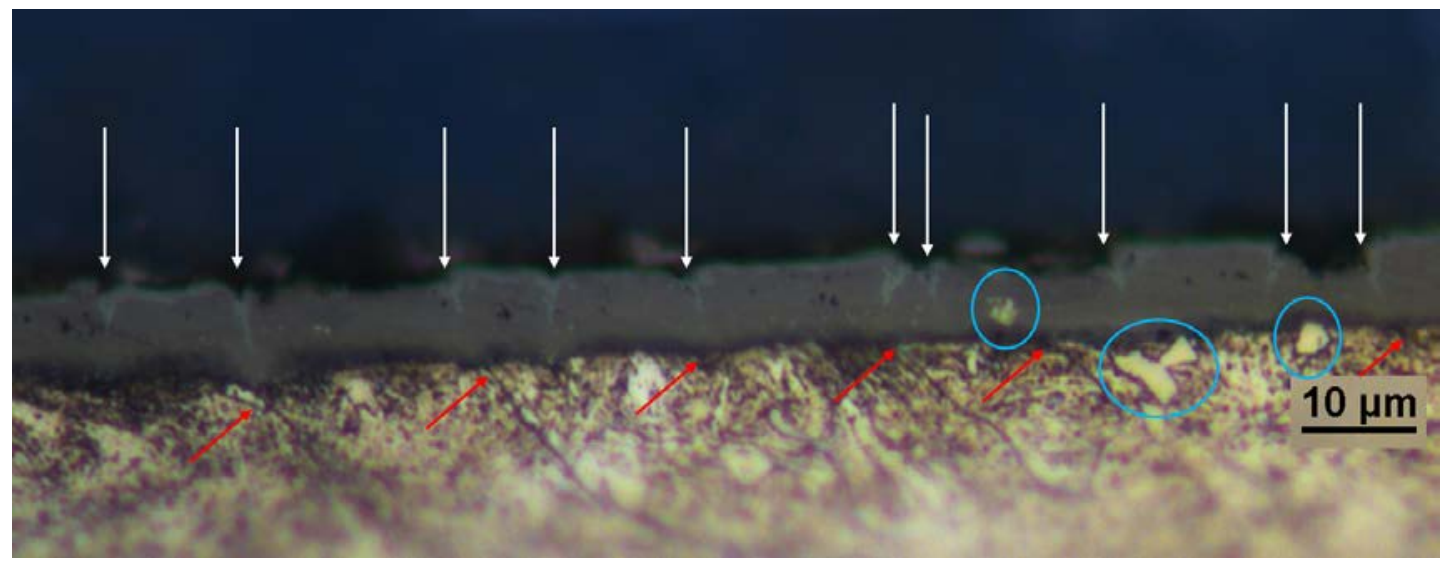

Figura 4.24: Pontos de oxidação preferencial formados durante ensaio de fadiga térmica, após ataque com Nital. As setas brancas indicam as trincas na camada de óxido; as setas vermelhas indicam contornos de grão que encontram a superfície; os círculos azuis indicam carbonetos na camada de óxido ou na interface óxido/matriz.

O formato em $V$ dos pontos de oxidação preferencial é atribuído à frente de difusão de oxigênio da superfície para o metal, favorecida pela região de menor ordenação atômica do contorno de grão, que forma a linha de centro do $\mathbf{V}$.

Os pontos não trincados geralmente coincidem com as trincas chamadas de trincas secundárias. Os pontos de oxidação profunda, com uma trinca central, são as chamadas trincas primárias. Desta forma, pode-se dizer que as trincas secundárias são as precursoras das trincas primárias.

Em outro estudo realizado pelo mesmo grupo de trabalho do $\mathrm{IPT}^{[70]}$, ensaiouse fadiga térmica no material X38CrMoV5-3 com dureza $450 \mathrm{HV}_{0,1}\left(\approx 46 \mathrm{HR}_{C}\right)$ em condições similares de ciclagem térmica aos estudos realizados neste trabalho na condição REF por 8250 ciclos (Figura 4.25), com a Bobina 1. Nesse material, que não possui carbonetos primários, é possível observar a formação de trincas diretamente na região da matriz, com os efeitos da oxidação. Como se vê na Figura 4.25a, a formação da trinca ocorre em 3 estágios: formação dos Vs, aprofundamento da oxidação e trincamento do óxido, fornecendo informações importantes sobre a ordem dos eventos. Na Figura 4.25b, vêem-se 3 regiões de oxidação profunda, sendo que apenas 2 delas estão trincadas. Nas regiões trincadas, a profundidade da trinca é menor que a profundidade do óxido, o que confirma a hipótese de que a oxidação acontece antes da abertura da trinca.

Como se vê, os fenômenos observados no material heterogêneo se aplicam também aos materiais homogêneos, uma vez que a preferência pela 


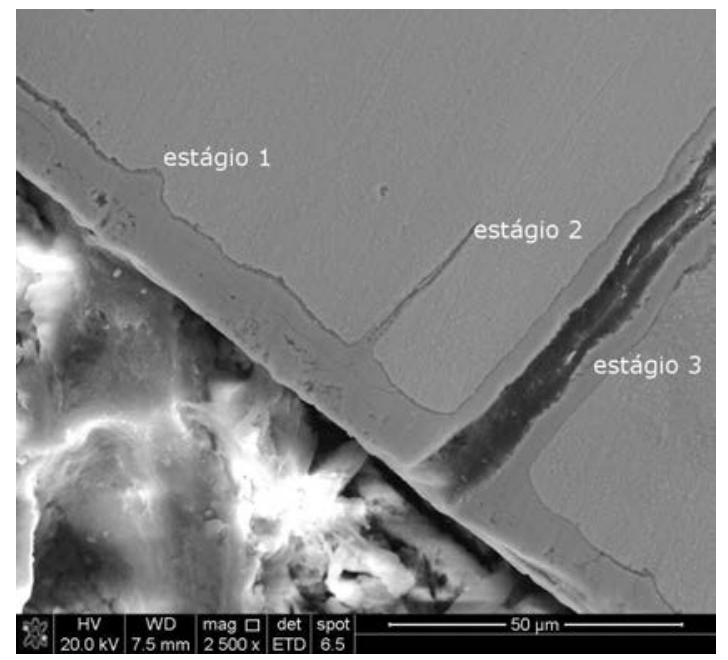

(a)

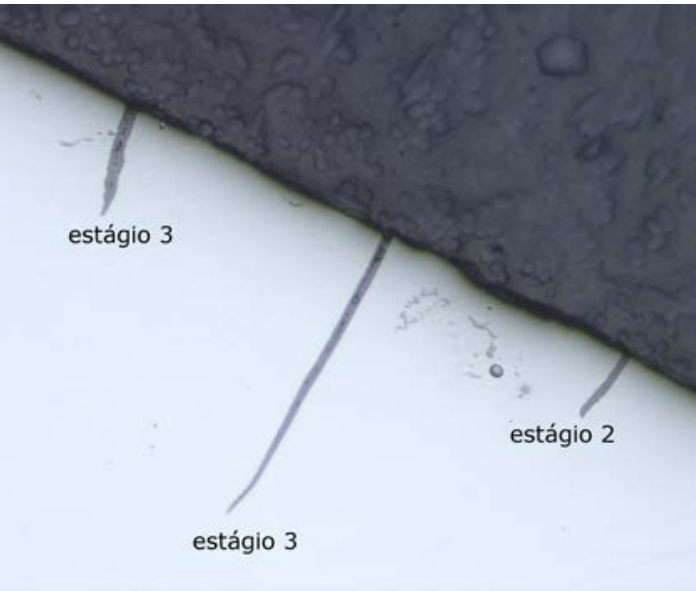

(b)

Figura 4.25: Formação de trincas de fadiga térmica no material X38CrMoV5-3 ensaiado no IPT em condição semelhante à condição REF. (a)

Estágios da formação de trinca: formação do $\mathbf{V}$, aprofundamento da oxidação, trincamento do óxido; (b) Exemplos do segundo e terceiro estágio da formação de trincas.

oxidação nos contornos de grão também se mostrou ocorrer longe dos carbonetos. O mecanismo proposto se aplica, portanto, para quaisquer aços semelhantes submetidos a ciclagem térmica em ambiente oxidante. 


\subsubsection{Ensaios de fadiga térmica}

\subsubsection{REF}

Entre os três corpos de prova ensaiados na condição REF, houve uma pequena diferença a respeito da condição superficial após 1000 ciclos, pois o corpo de prova REF1 encontrava-se em um nível de dano menos adiantado que os demais. Não foi possível levantar a causa dessa diferença. Entretanto, a densidade de trincas dos três corpos de prova se igualou no restante do ensaio. O número de ciclos para falha médio entre os 3 CPs foi de 3333 ciclos.

Quanto à observação da superfície no microscópio óptico, o primeiro fenômeno que se nota, junto com a oxidação da superfície, é a criação de relevo entre a matriz e os carbonetos, que aparecem "saltados" sobre a matriz (Figura 4.26a). Com o avanço do dano (2000 ciclos, Figura 4.26b, as trincas parecem conectar todos os carbonetos, de onde podem partir até 6 trincas. Conforme a oxidação avança, aumentam os pontos de ocorrência de um óxido diferente do filme formado originalmente, de cor acinzentada, desta vez de cor marrom escuro e contido ao redor dos carbonetos. Na Figura 4.26c, nota-se maior número de carbonetos trincados, com suas trincas alinhadas nas direções das trincas sobre a matriz. Ao final do experimento, com o afloramento de uma trinca primária que causou vazamento de água, houve contaminação da superfície formando o óxido de ferro avermelhado (Figura 4.26d). 


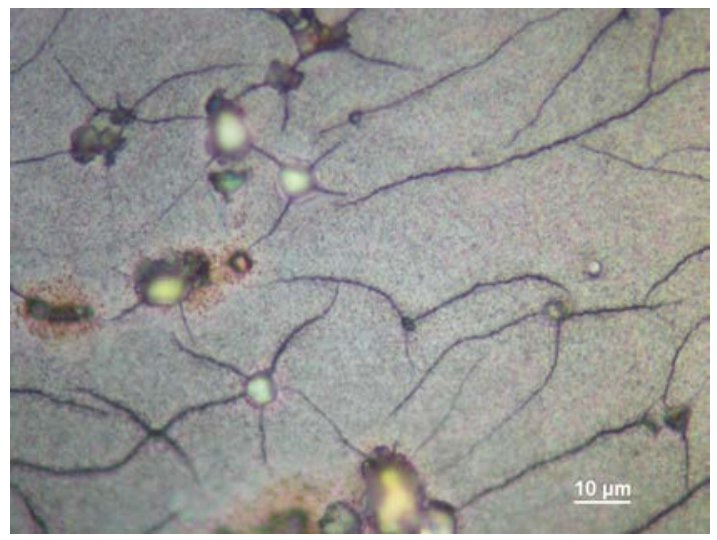

(a)

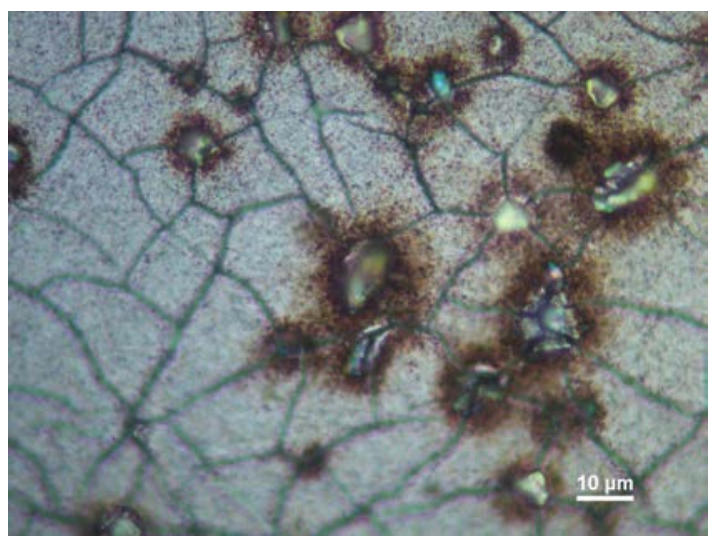

(c)

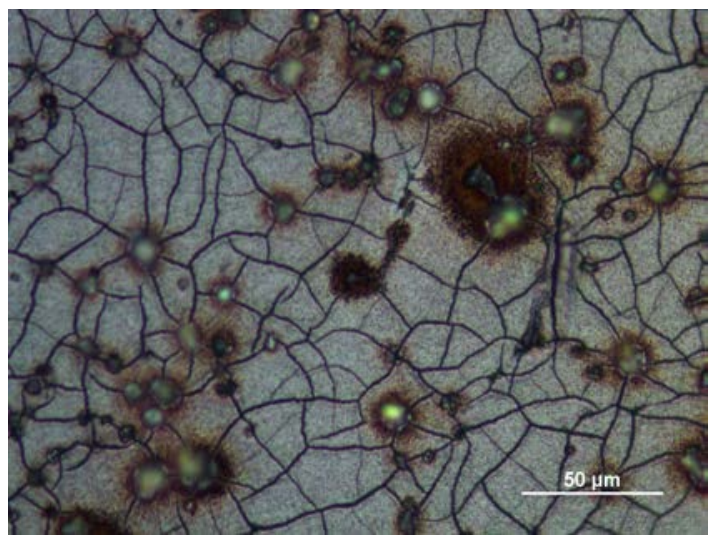

(b)

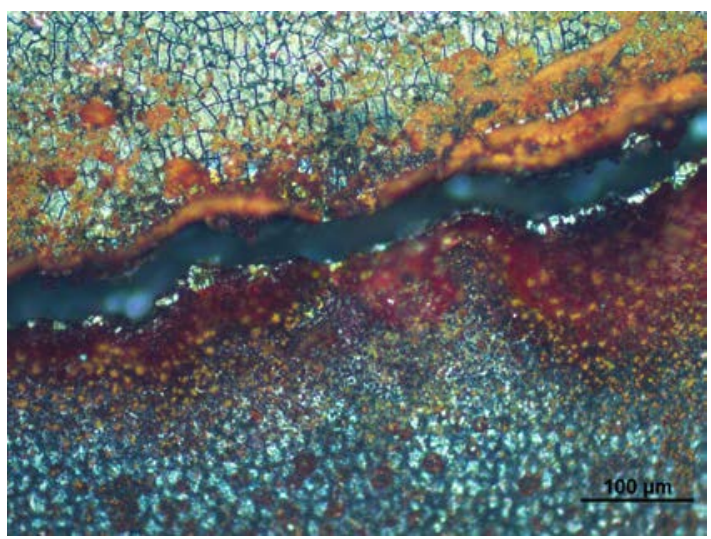

(d)

Figura 4.26: Evolução do dano superficial do corpo de prova REF1 após os primeiros 1000 ciclos. (a) CP após 1000 ciclos térmicos, com superfície oxidada e relevo criado entre os carbonetos e a matriz (carbonetos ficam desfocados na imagem). As trincas nucleiam na interface carboneto/matriz, preferencialmente nos cantos (1000x); (b) Após 2000 ciclos, trincas conectam todos os carbonetos, de onde podem partir até 6 trincas $(500 \mathrm{x})$; (c) Após 3000 ciclos, pontos de ocorrência de óxido de cor marrom escuro e carbonetos trincados (1000x); (d) Contaminação da superfície pelo vazamento de água por uma trinca primária (200x).

A Figura 4.27 e Figura 4.28 mostram o avanço do dano nos CPs REF2 e REF3, respectivamente. A falha do CP REF3 foi prematura devido à presença de defeitos de fundição. Nesse caso, quando a trinca primária nucleia antes da formação da malha secundária, as trincas da malha secundária seguem um padrão diferente, devido ao alívio de tensões causado pela presença da trinca primária. A malha secundária, nessas regiões, é formada por linhas paralelas e não um padrão quadriculado. As linhas partem da trinca primária e seguem perpendiculares a ela. 


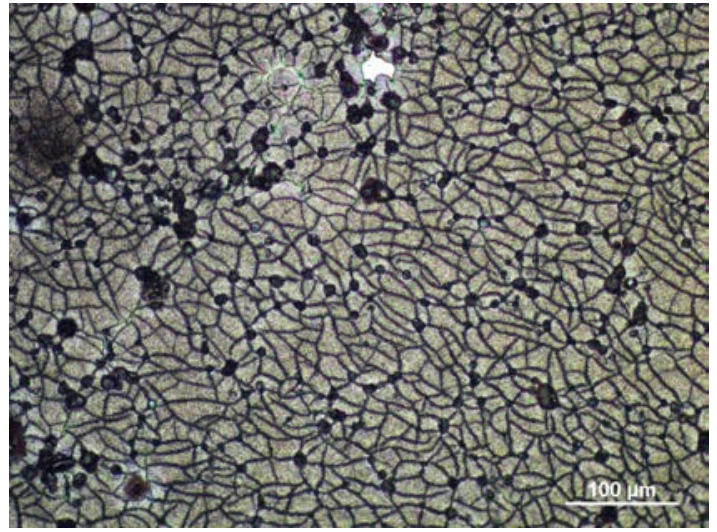

(a)

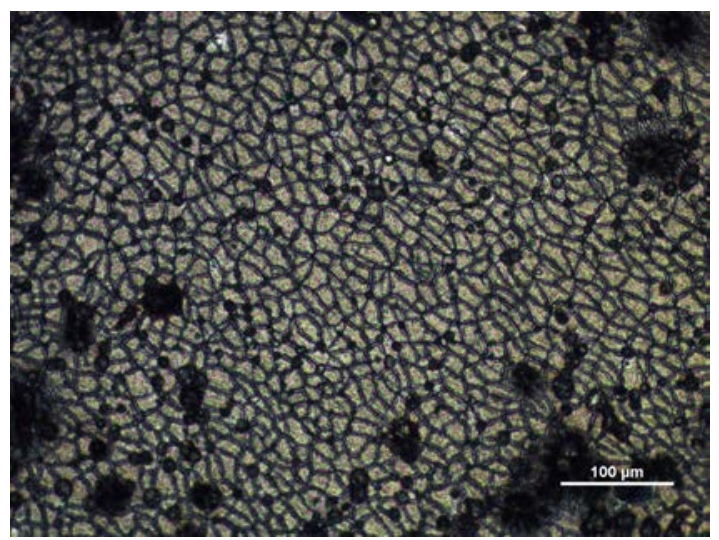

(c)

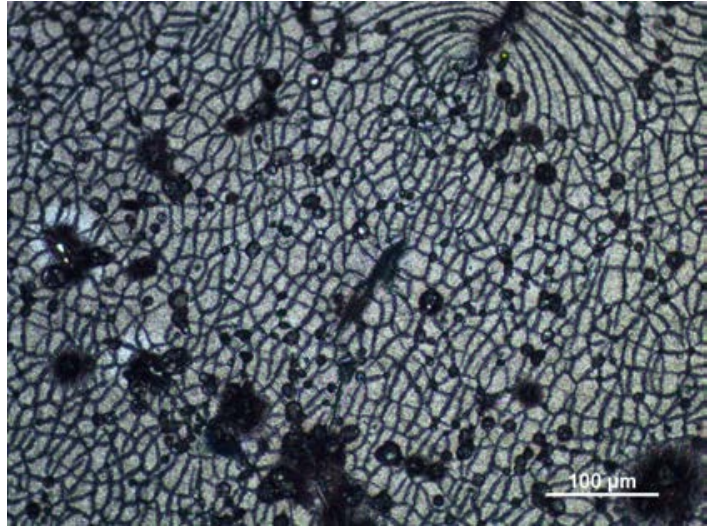

(b)

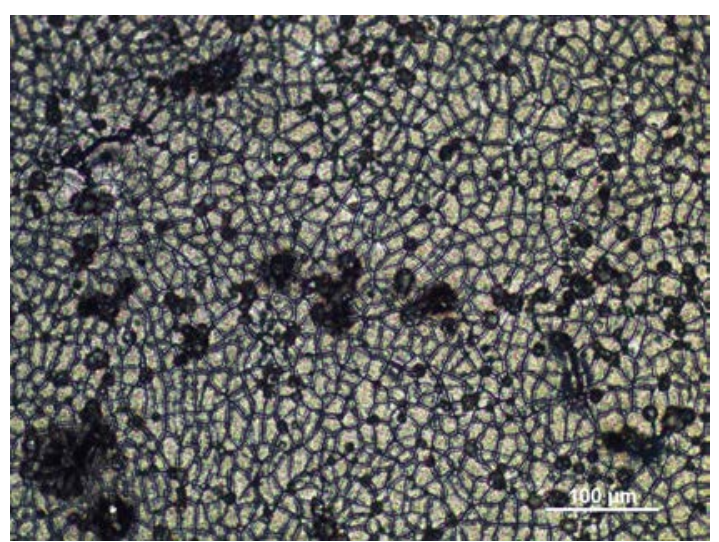

(d)

Figura 4.27: Evolução do dano superficial do corpo de prova REF2. (a) Após 1000 ciclos; (b) 2000 ciclos; (c) 3000 ciclos; (d) 4000 ciclos. 


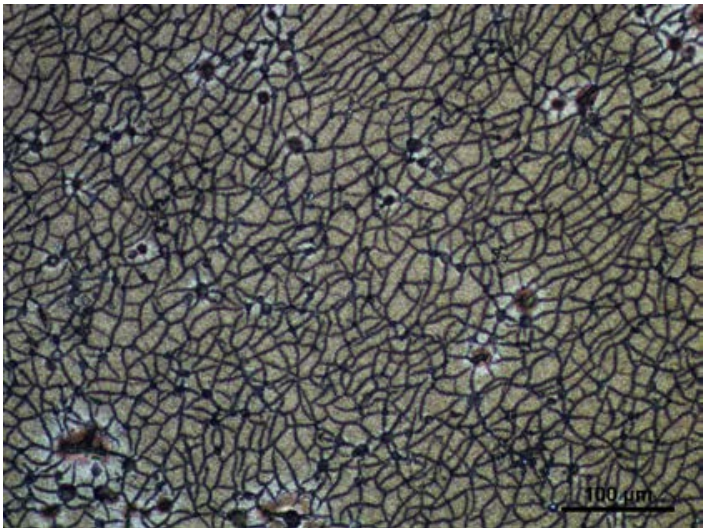

(a)

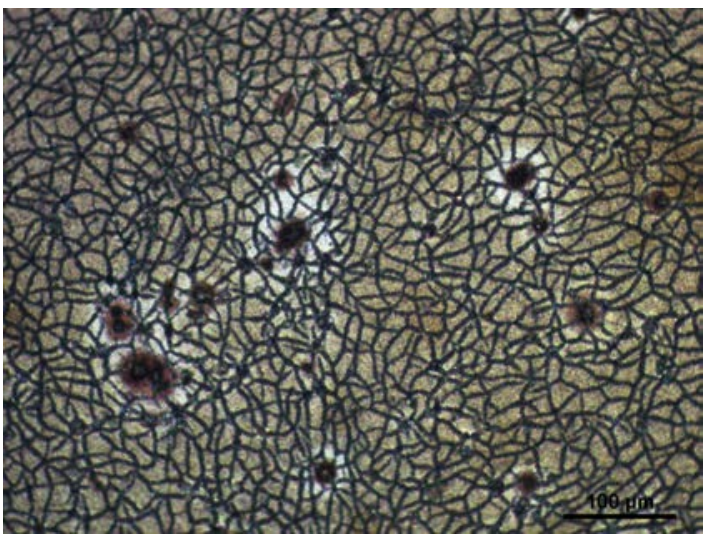

(c)

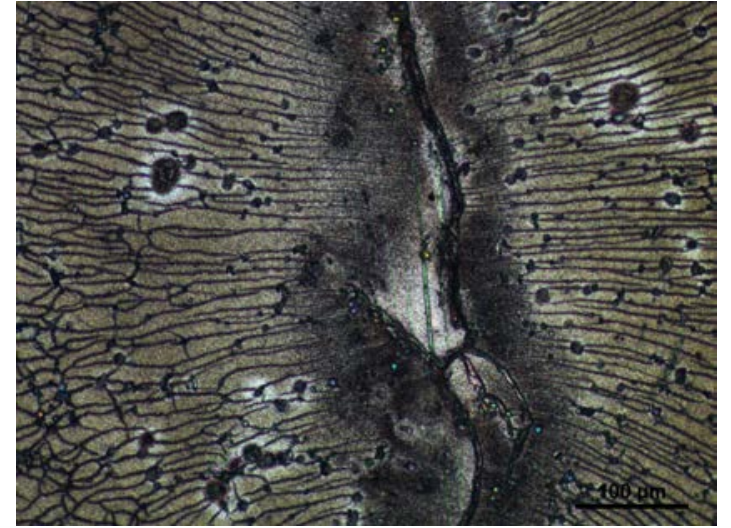

(b)

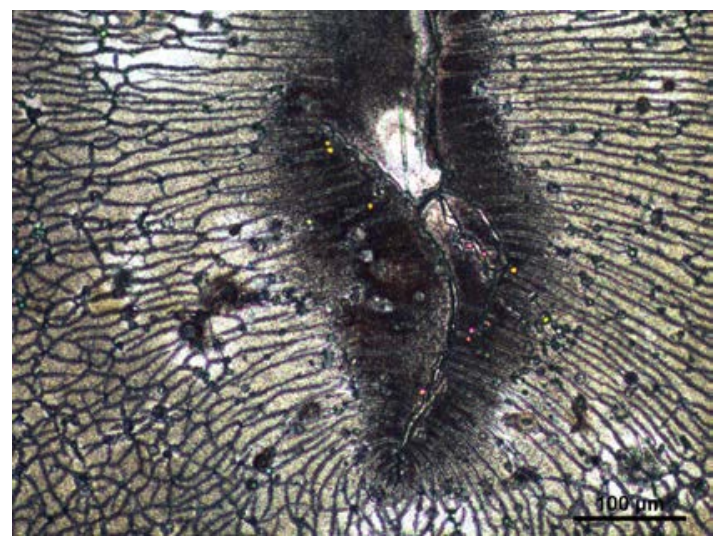

(d)

Figura 4.28: Evolução do dano superficial do corpo de prova REF3. (a) Após 1000 ciclos; (b) Após 1000 ciclos, na região de uma trinca formada sobre um defeito de fundição; (c) 2000 ciclos; (d) 2000 ciclos, na região da trinca primária, com malha de trincas secundárias seguindo padrão de linhas paralelas, todas perpendiculares à trinca primária. 
A Figura 4.29 mostra as medidas de densidade de trincas secundárias nos CPs REF1, REF2 e REF3.

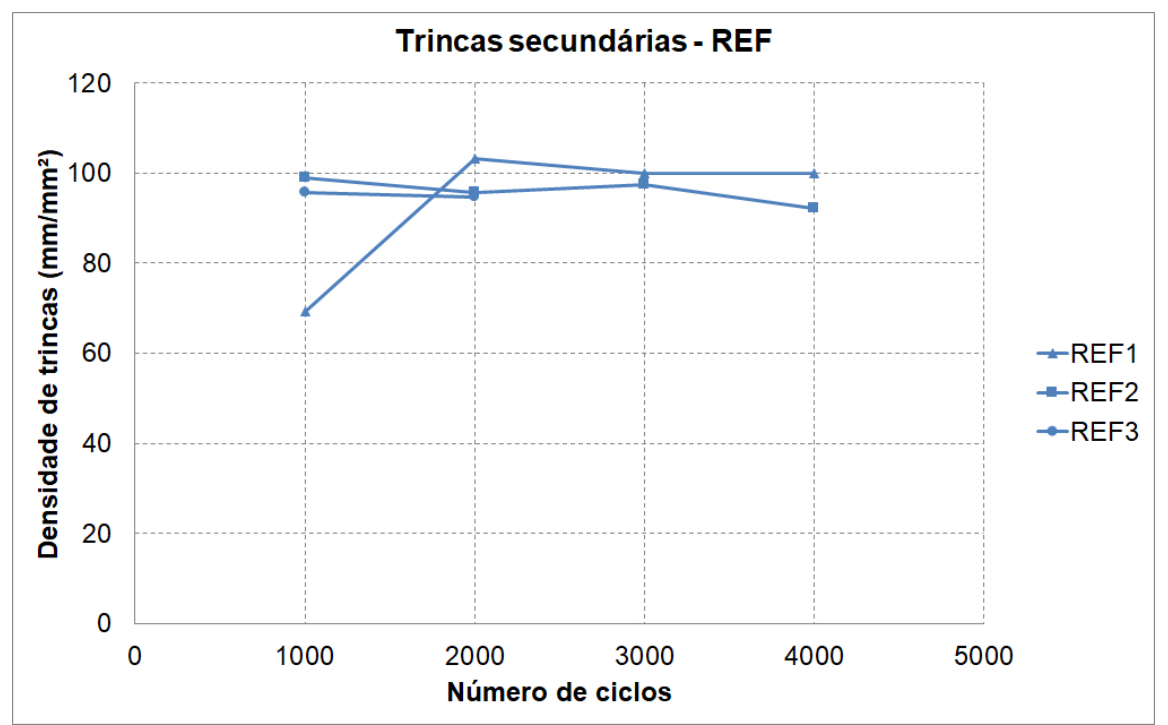

Figura 4.29: Medidas de densidade de trincas nos corpos de prova ensaiados na condição REF. 


\subsubsection{HOT}

O aumento da temperatura pode implicar em:

- Formação óxidos com composição e espessuras diferentes da condição de referência;

- Diferentes propriedades mecânicas da matriz (dureza, limite de escoamento, limite de resistência, tenacidade etc.);

- Maior susceptibilidade ao revenimento;

- Maior gradiente de temperaturas do ciclo térmico, resultando em maiores dilatações da superfície durante o ciclo térmico;

- Maior deformação plástica da superfície em compressão e maior tração durante o resfriamento, como foi visto na Figura 4.13;

- Menor vida em fadiga e fadiga térmica. ${ }^{[3]}$

Foram realizados 3 experimentos na condição HOT. Todos os outros corpos de prova falharam antes de 1000 ciclos. A condição da superfície dos 3 CPs após os ensaios é mostrada na Figura 4.30. 


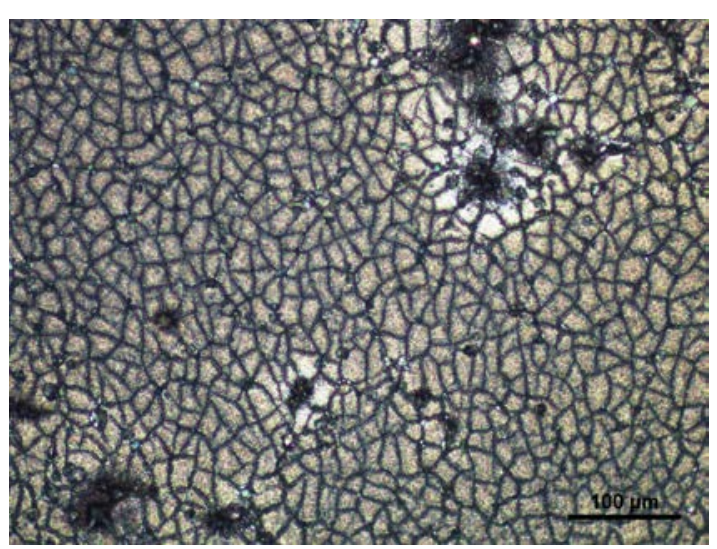

(a)

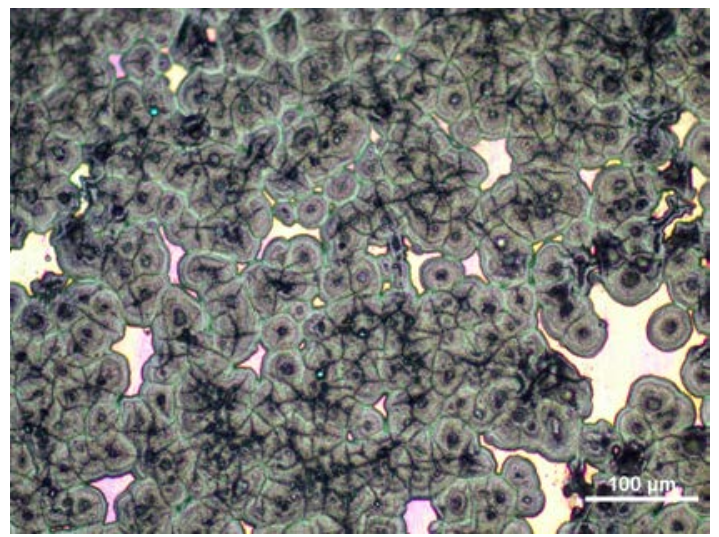

(c)

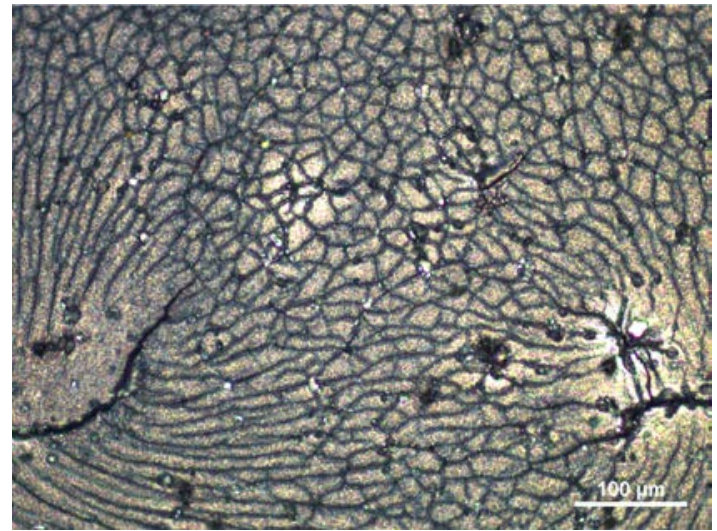

(b)

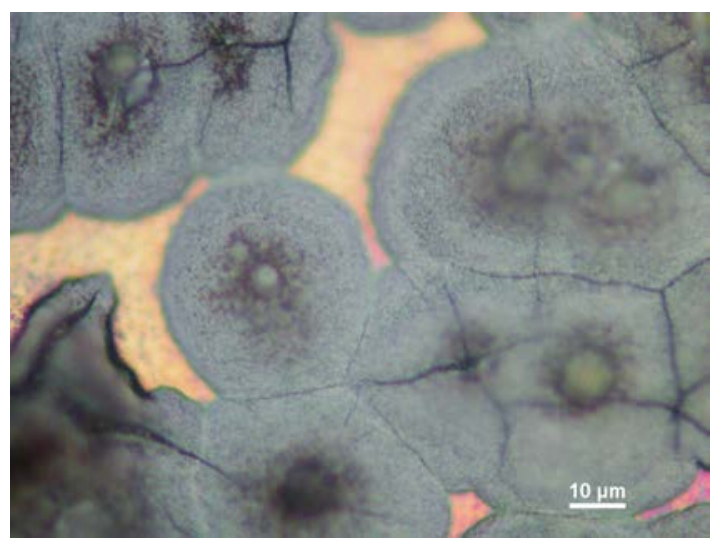

(d)

Figura 4.30: Superfície dos corpos de prova ensaiados na condição HOT. (a) HOT1, após 1000 ciclos; (b) HOT2, após 1000 ciclos, região entre duas trincas primárias ; (c) HOT3, após 450 ciclos (200x); (d) Mesma amostra, com 1000x. Nesta amostra, é possível ver o óxido ainda em formação, crescendo em forma celular. Pode-se ver ainda regiões da matriz não oxidadas (pontos brilhantes); 
A Figura 4.31 mostra as medidas de densidade de trincas secundárias nos CPs HOT1, HOT2 e HOT3. De fato, como era previsto, a vida dos materiais quando aquecidos até uma temperatura maior foi reduzida para uma média de 817 ciclos. Como todos os corpos de prova falharam antes de 1000 ciclos, não foi possível traçar curvas de evolução da densidade de trincas. Cada corpo de prova é representado no gráfico apenas por um ponto.

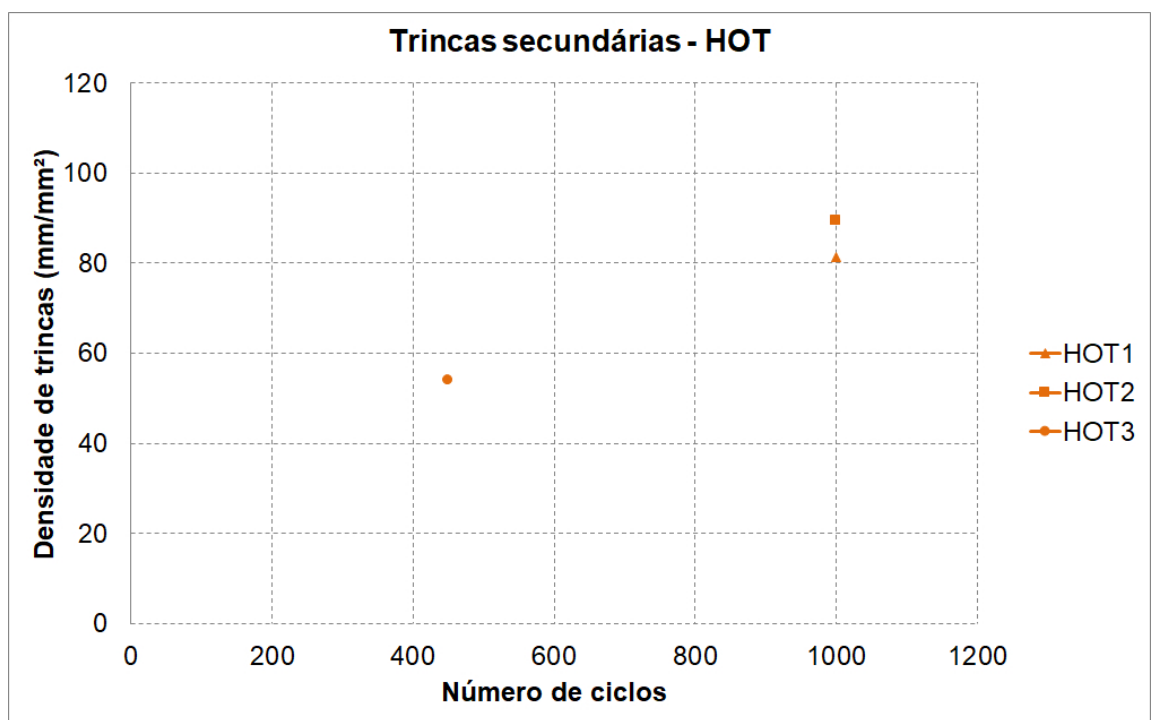

Figura 4.31: Medidas de densidade de trincas secundárias nas amostras ensaiadas na condição HOT. Cada corpo de prova é representado no gráfico apenas por um ponto. 


\subsubsection{LOW}

A diminuição da velocidade de aquecimento pode implicar em:

- Maior tempo de exposição à alta temperatura, aumentando a espessura de óxido na superfície;

- Maior tempo para condução de calor, resultando em maior penetração de calor para o interior do corpo de prova;

- Menor gradiente de temperaturas ao longo da espessura, resultando em menores tensões na superfície durante o ciclo térmico, como visto na Figura 4.13;

- Maior susceptibilidade ao revenimento;

- Menor densidade de trincas térmicas secundárias. ${ }^{[3]}$

Em uma amostra, ensaiada na condição LOW, foi possível observar o início da formação da camada de óxido. A Figura 4.32. Comparando regiões diferentes da amostra, conclui-se que a oxidação inicia ao redor dos carbonetos e cresce de forma celular até cobrir toda a superfície da matriz. As trincas no óxido que partem dos carbonetos em forma de "aranhas" já começam a se nuclear e propagar desde o começo da formação da camada de óxido.

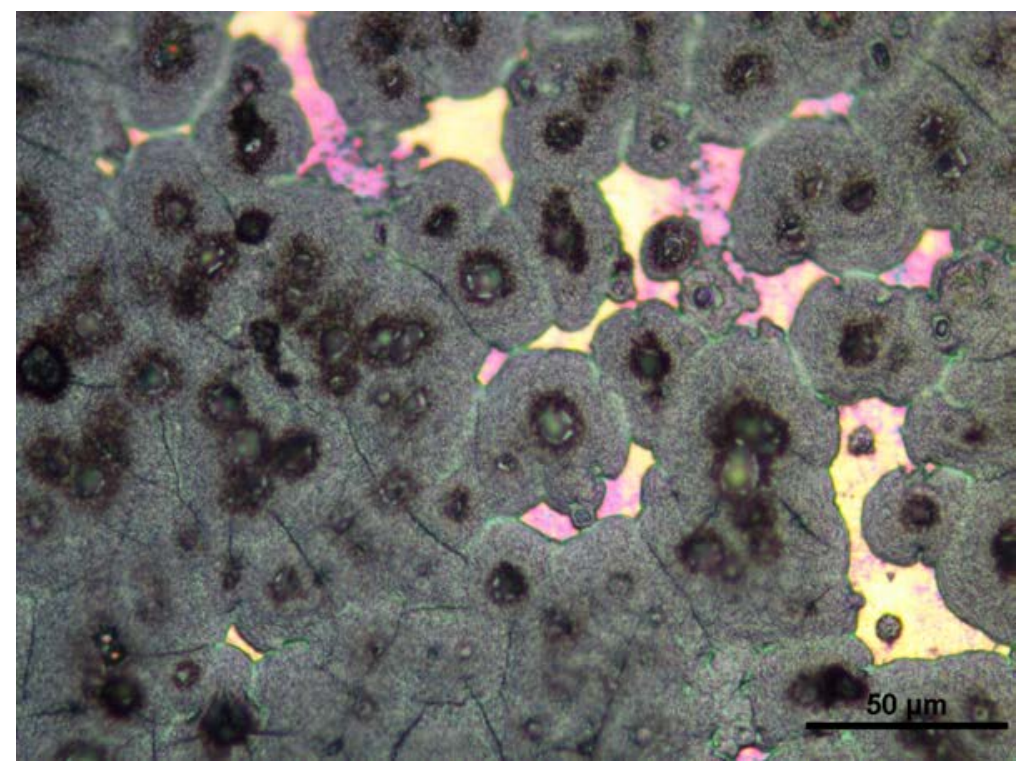

Figura 4.32: Morfologia da camada de óxido no início da formação. O óxido começa a crescer a partir da interface carboneto/matriz e avança sobre a matriz em formas circulares, como um crescimento celular. Algumas trincas já nucleiam nesse estágio, propagando em forma de "aranhas" a partir dos carbonetos. 
A evolução do dano superficial sobre os corpos de prova ensaiados na condição LOW é mostrada nas Figuras 4.33, 4.34 e 4.35. Observa-se que, da mesma forma como aconteceu com a condição REF, aos 1000 ciclos a densidade de trincas já estava no seu valor estável. Entretanto, é visível o menor número de trincas quando o aquecimento é realizado com menor velocidade. Alguns carbonetos permanecem até o final do ensaio sem trincas, e dos carbonetos trincados partem no máximo 4 trincas. Não foram observadas trincas primárias nucleando a partir da malha de trincas secundárias.

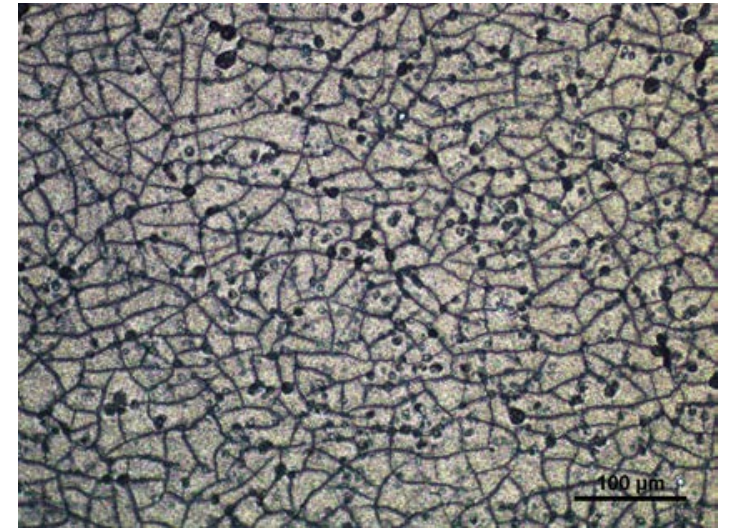

(a)

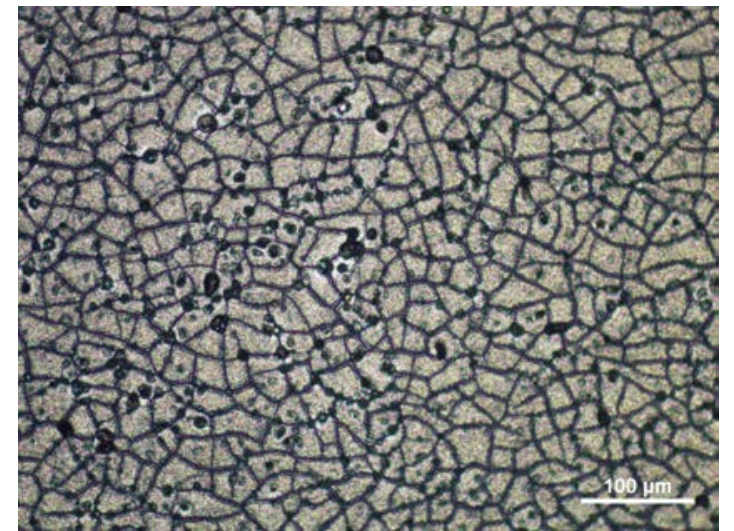

(b)

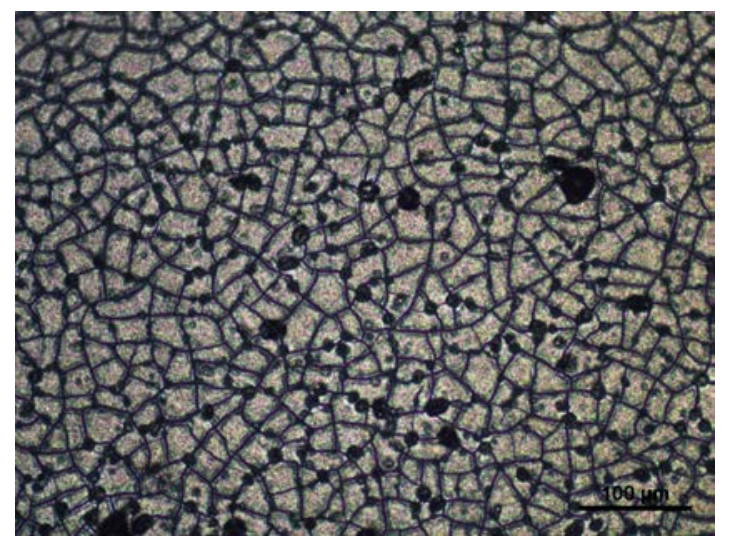

(c)

Figura 4.33: Evolução do dano superficial do corpo de prova LOW1. (a) Após 1000 ciclos, nota-se a malha de trincas já formada, porém há menor número de trincas e de carbonetos trincados; (b) Após 2000 ciclos, a densidade de trincas se manteve constante; (c) Após 3000 ciclos, maior número de pontos de oxidação marrom escura, e sem trincas primárias. 


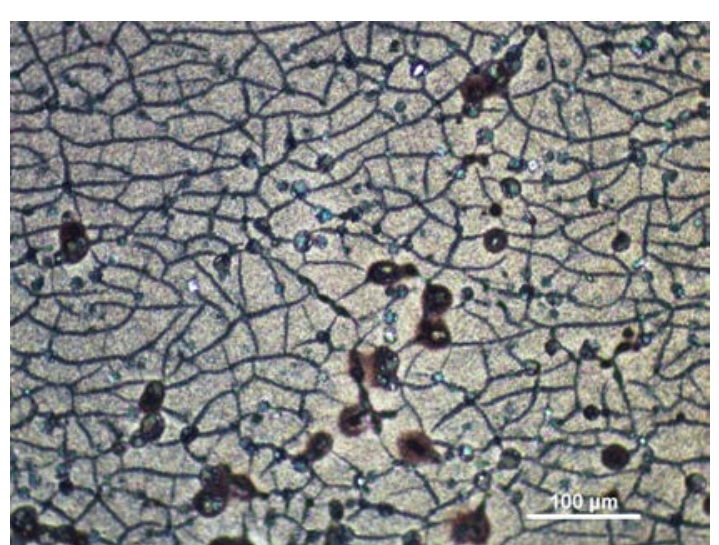

(a)

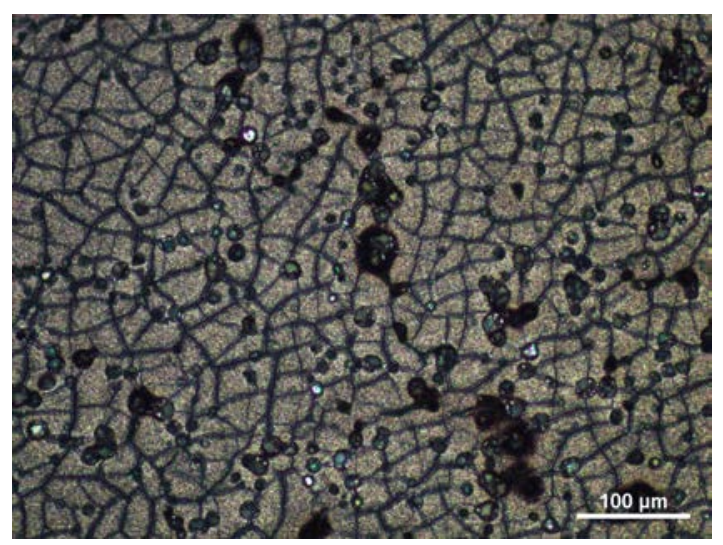

(c)

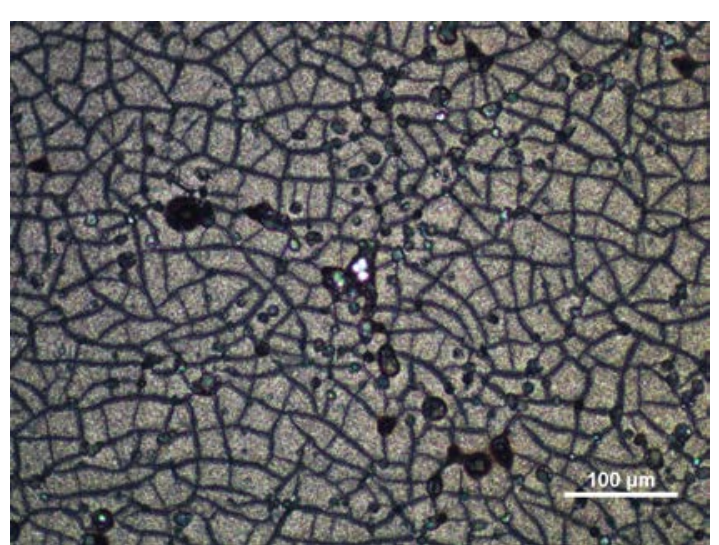

(b)

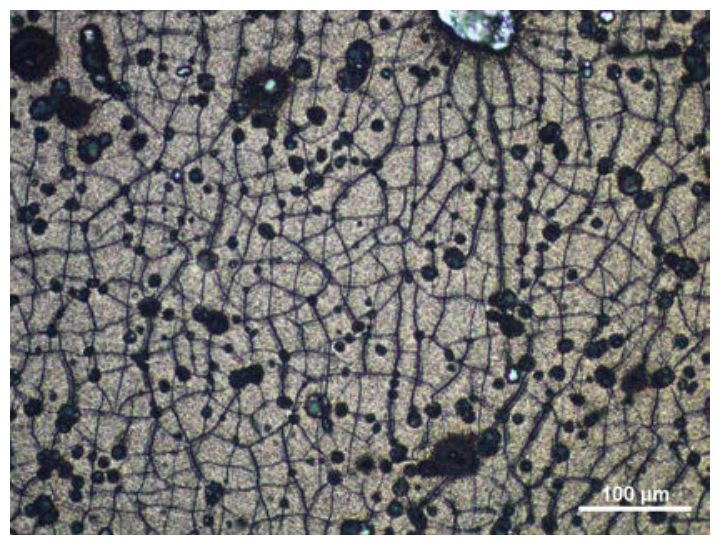

(d)

Figura 4.34: Evolução do dano superficial do corpo de prova LOW2. (a) Após 1000 ciclos; (b) 2000 ciclos; (c) 3000 ciclos; (d) 4000 ciclos. 


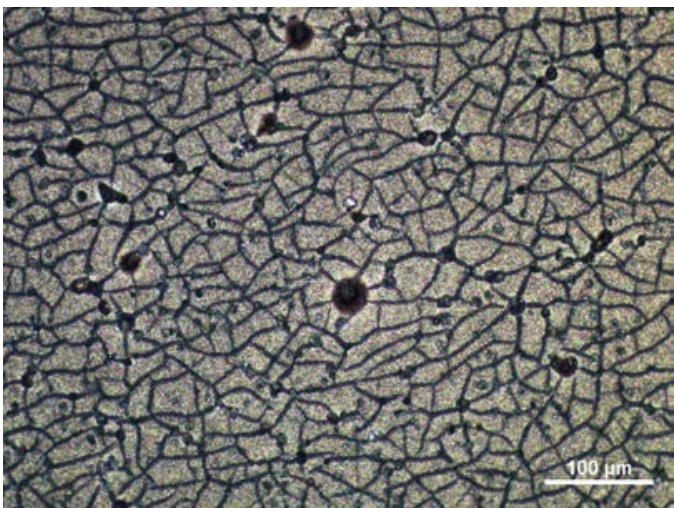

(a)

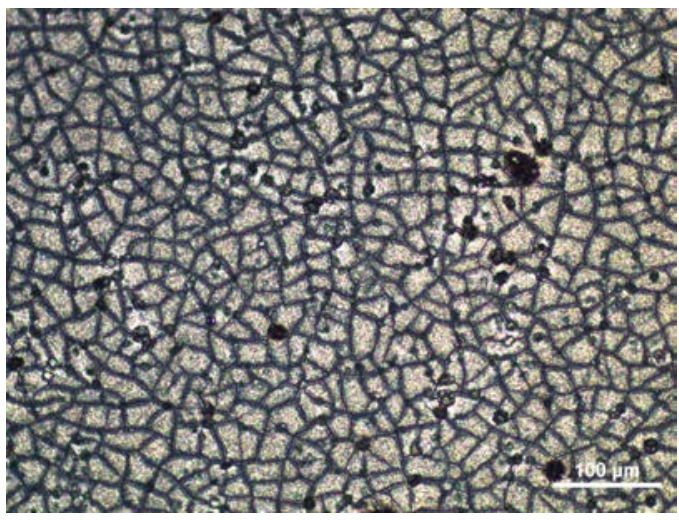

(c)

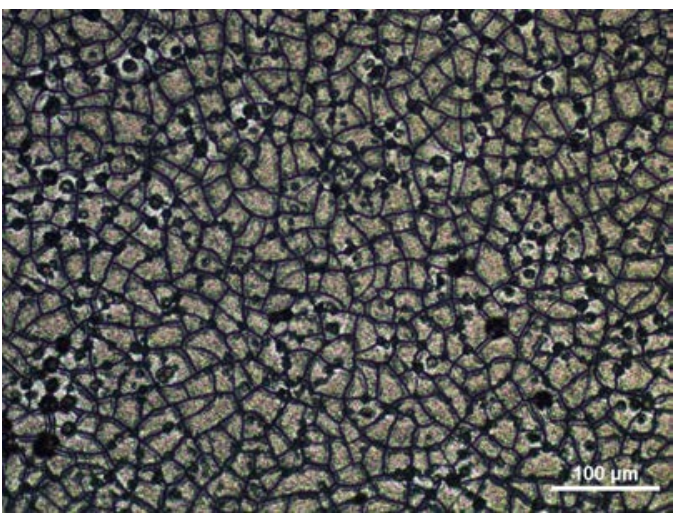

(e)

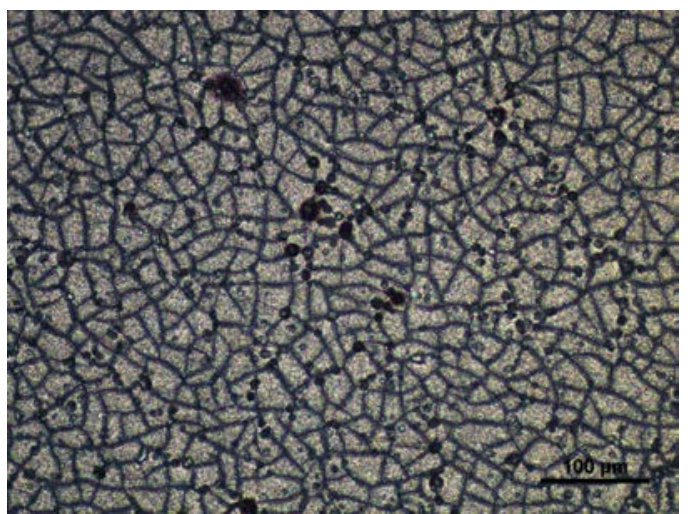

(b)

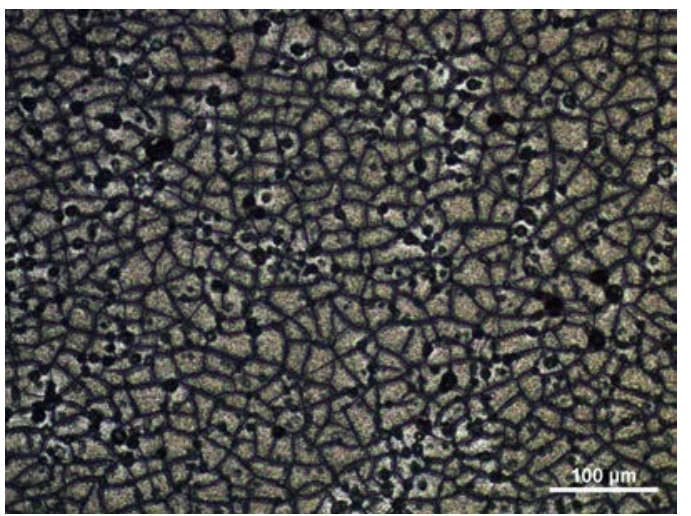

(d)

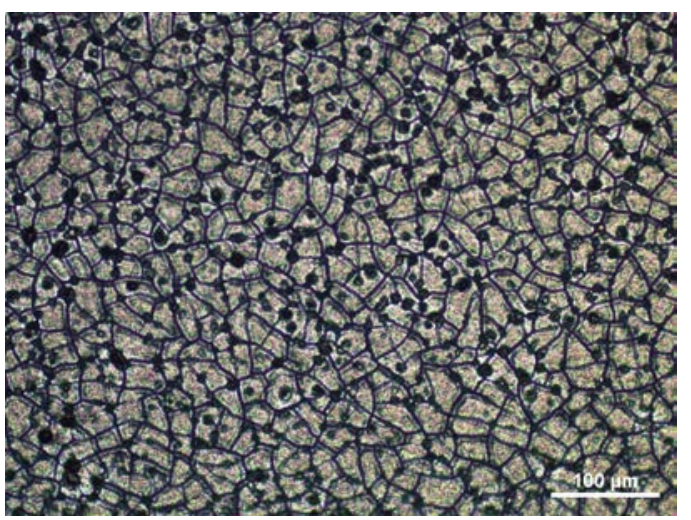

(f)

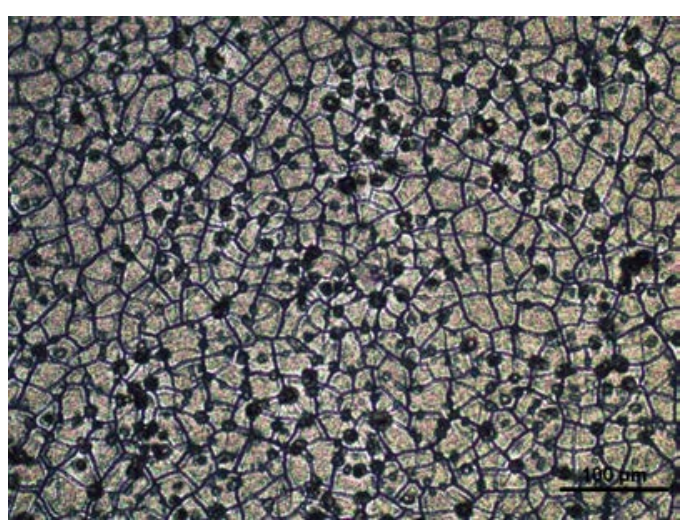

(g)

Figura 4.35: Evolução do dano superficial do corpo de prova LOW3. (a) Após 1000 ciclos; (b) 2000 ciclos; (c) 3000 ciclos; (d) 4000 ciclos; (e) 5000 ciclos; (f) 6000 ciclos; (g) 7000 ciclos. O corpo de prova não falhou. 
O corpo de prova LOW3 foi o de maior longevidade, suportando até 7000 sem a nucleação de nenhuma trinca primária; o ensaio foi interrompido.

A Figura 4.36 mostra as medidas de densidade de trincas secundárias nos CPs LOW1, LOW2 e LOW3. Quanto à vida média dos corpos de prova, houve ganho de tempo de vida em relação à condição REF de 3333 para mais de 4666 ciclos.

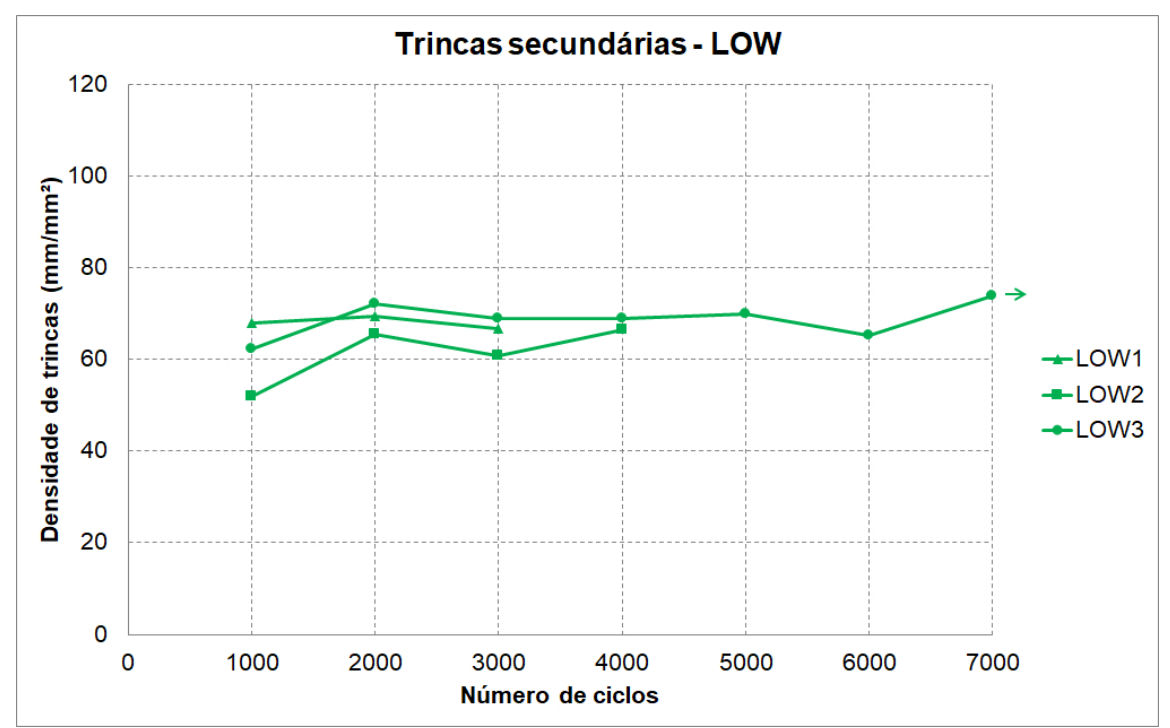

Figura 4.36: Medidas de densidade de trincas secundárias nas amostras ensaiadas na condição LOW. 


\subsubsection{REV}

O tratamento térmico de super-revenimento realizado nos corpos de prova REV foi feito aquecendo-o a $700^{\circ} \mathrm{C}$ por 1 hora. O tamanho de grão médio do material não sofreu alterações e a camada descarbonetada da superfície foi removida por usinagem, realizando-se uma retífica para remoção de uma camada de $0,1 \mathrm{~mm}$.

A utilização do material no estado super-revenido pode implicar em: ${ }^{[71]}$

- Menor susceptibilidade a alterações microestruturais durante o ensaio;

- Menor dureza, aumentando o número de trincas primárias iniciadas;

- Maior tenacidade à fratura da matriz, diminuindo a propagação de trincas ${ }^{[26]}$;

- Igual densidade de trincas secundárias, uma vez que estejam associadas à oxidação e às tensões térmicas (hipótese a confirmar).

A evolução dos danos superficiais do corpo de prova REV1 é mostrada na Figura 4.37. 


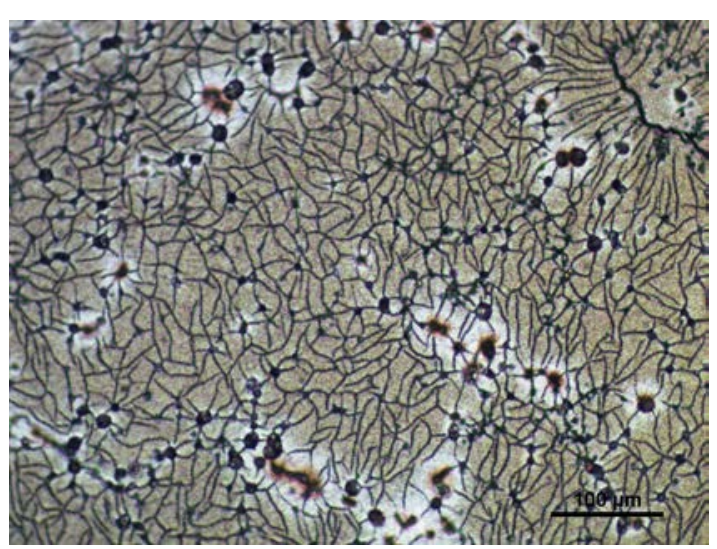

(a)

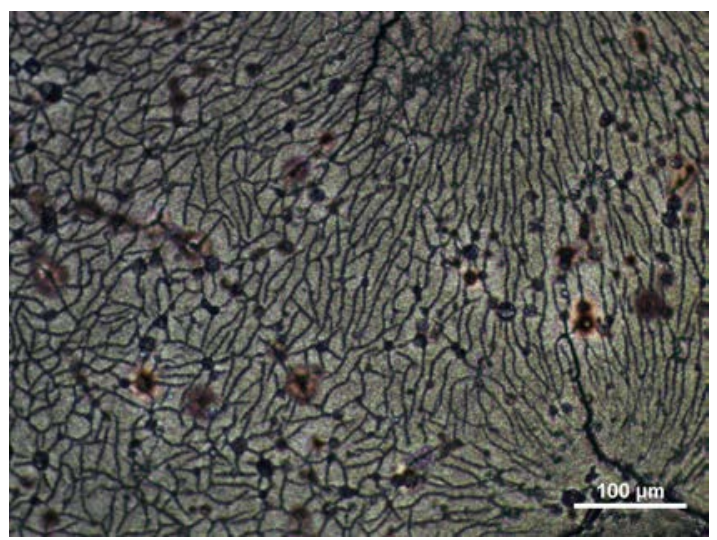

(c)

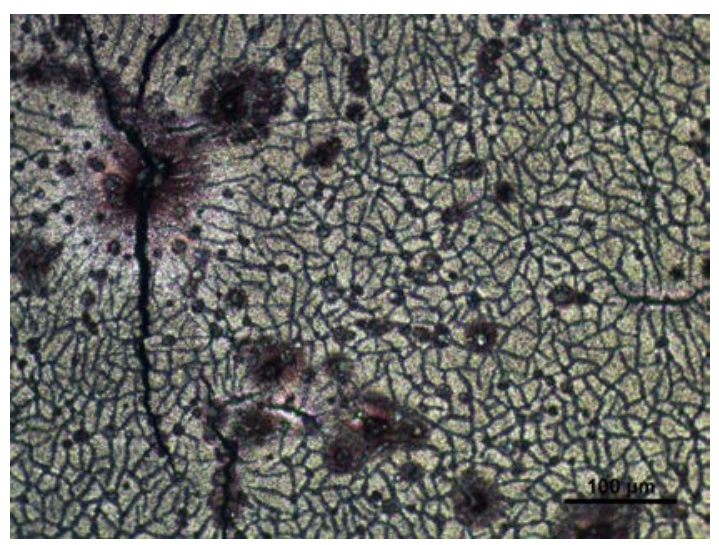

(e)

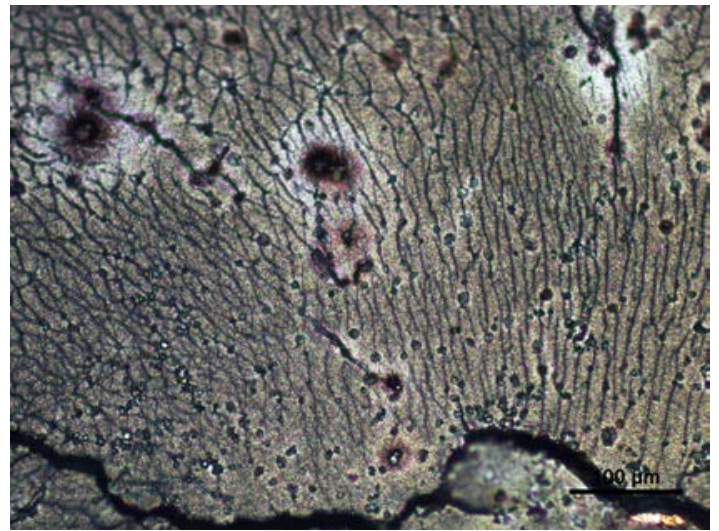

(b)

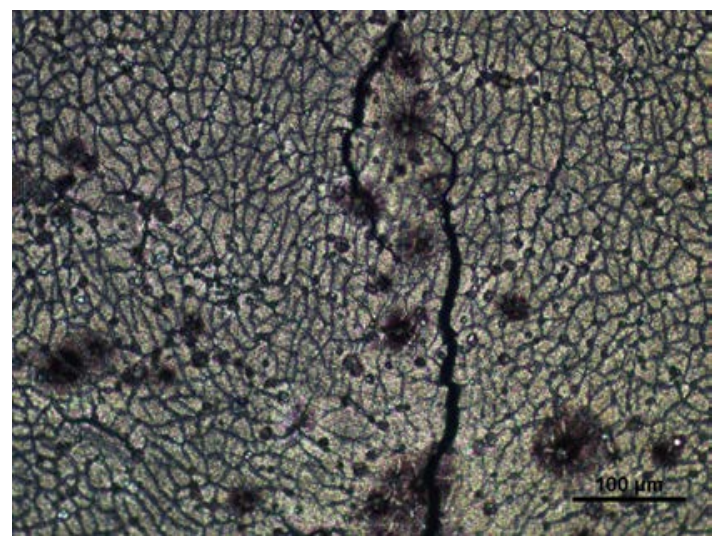

(d)

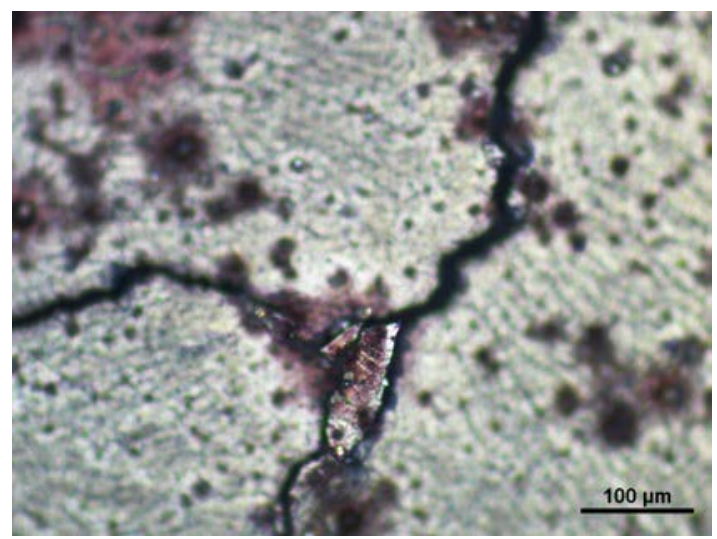

(f)

Figura 4.37: Evolução do dano superficial do corpo de prova REV1. (a) Após 1000 ciclos, malha de trincas secundárias ainda em formação, porém já com presença de trincas primárias; (b) 2000 ciclos grande trinca nucleada em um defeito de fundição. A malha de trincas secundárias adquire forma diferente (linhas paralelas) próximo a defeitos como este; (c) 3000 ciclos, inicia a conexão entre carbonetos formando uma trinca primária; (d) 4000 ciclos, trincas primárias propagando pela malha de trincas secundárias, prestes a se conectar; (e) 5000 ciclos, aumento do número de trincas primárias; (f) 6000 ciclos, porção do material destacada da superfície devido à conexão de trincas (arrancamento). 
Os CPs ensaiados nessa condição foram os únicos ensaiados ao ar que não tiveram vazamento de água no final do ensaio. Os ensaios tiveram que ser interrompidos devido ao início de casos de arrancamento de material, causado pela conexão de trincas primárias, que nuclearam em muito maior número do que os outros corpos de prova ensaiados nas condições REF, HOT e LOW. A Figura 4.38 mostra a condição da superfície, com detalhes para pontos de perda de material.

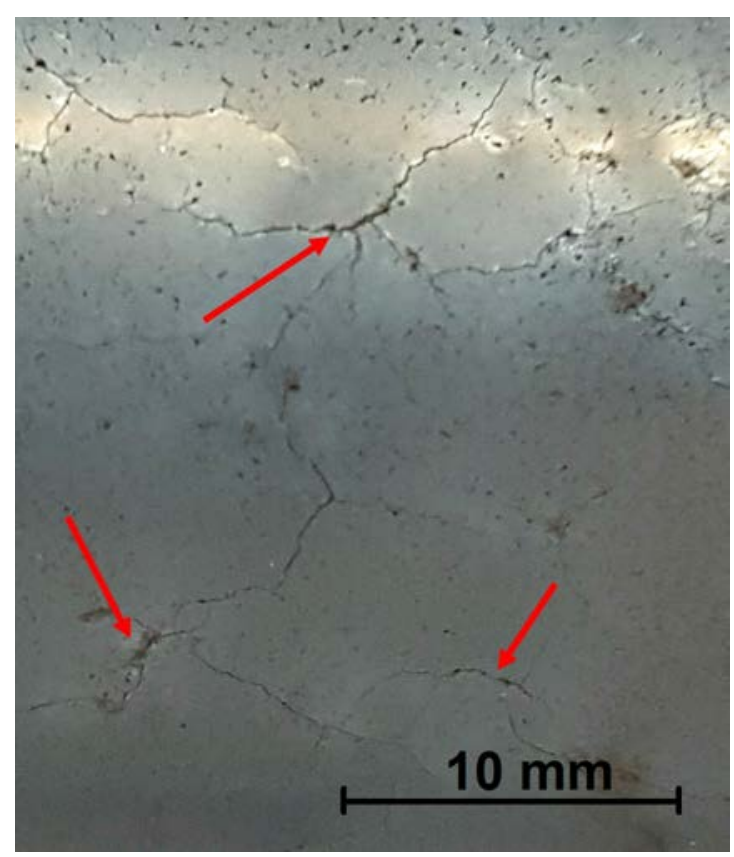

Figura 4.38: Superfície do corpo de prova REV1 após 6000 ciclos, indicando pontos de perda de material em meio à malha de trincas primárias.

A Figura 4.39 mostra as medidas de densidade de trincas secundárias nos CPs REV1, REV2 e REV3. Quanto à vida média dos corpos de prova, apesar da grande variação entre o REV1, com vida de 6000 ciclos, e o REV3, com 1000, a média permaneceu igual à condição de referência REF, de 3333 ciclos. 


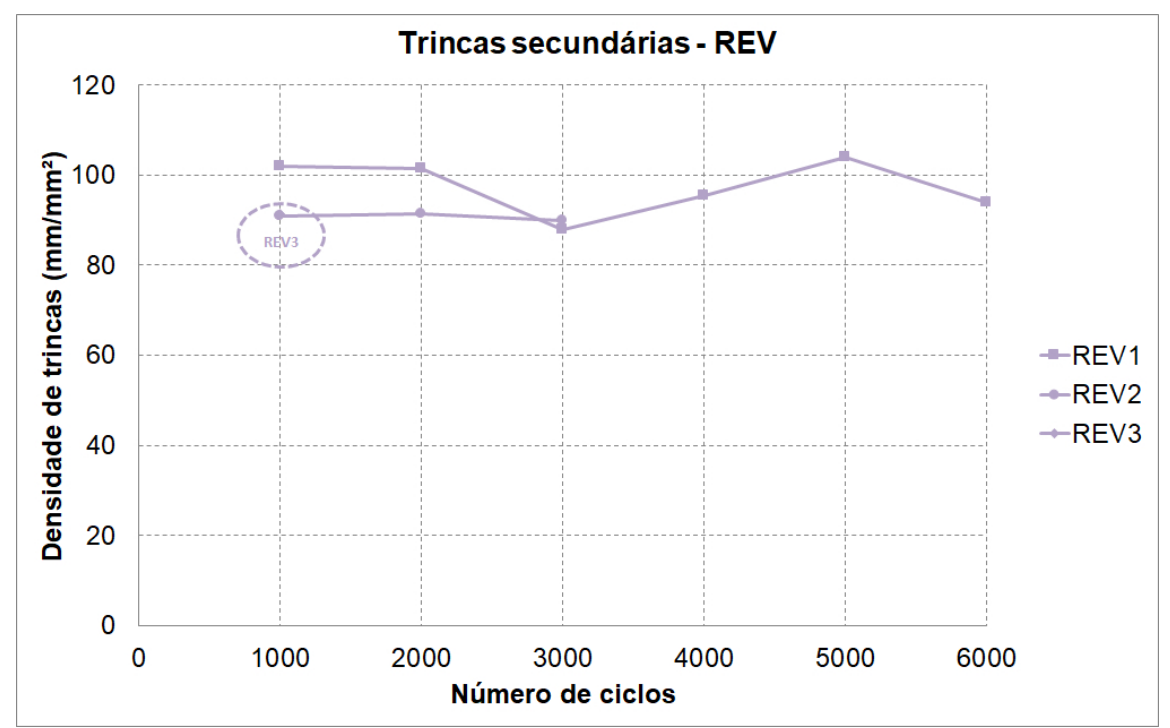

Figura 4.39: Medidas de densidade de trincas secundárias nas amostras ensaiadas na condição REV. 


\subsubsection{ARG}

A diminuição do potencial oxidante da atmosfera pode implicar em:

- Diminuição ou supressão da oxidação da superfície;

- Mesma susceptibilidade ao revenimento;

- Submissão do material apenas ao carregamento térmico;

- Diminuição ou supressão da malha de trincas secundárias;

- Restrição dos concentradores de tensão apenas aos carbonetos e defeitos do material;

- Nucleação de trincas primárias apenas condicionada aos fenômenos de fadiga.

É importante dizer que o ensaio sob argônio trouxe algumas dificuldades que tiveram que ser contornadas:

- Houve formação de uma camada superficial mais fina que a camada de óxido vista nos outros ensaios, porém de coloração diferente, mais marrom, enquanto os outros formam camada em tons de azul e cinza. Essa camada é pouco aderente e se desprende facilmente da superfície durante o ensaio ou ao suave toque de um algodão. É necessário caracterizar este composto formado separadamente das demais amostras, portanto as trincas formadas nessa camada, quando presentes, não foram contabilizadas nas medidas de densidade de trincas secundárias;

- O pirômetro necessita de boa emissividade ${ }^{1}$, e a superfície do aço polido tem emissividade muito baixa. Isso dificulta a leitura de temperatura durante o ensaio se ele não está exposto a oxidação, e causa erros de leitura do pirômetro que acarretam em erros no controle do forno de indução feito pelo controlador.

Para contornar a baixa emissividade na região da medição de temperatura, foram realizadas algumas tentativas de pintar uma pequena área

${ }^{1}$ Emissividade é a capacidade de um objeto emitir radiação eletromagnética (neste caso, energia infravermelha) quando o comparado com o chamado "corpo negro" para a mesma temperatura e comprimento de onda. A energia emitida é proporcional à quarta potência da temperatura de um objeto. Emissividade pode ser um valor de 0 (refletida por um espelho) até 1,0 (corpo negro teórico). Muitos materiais orgânicos, revestidos ou superfícies oxidadas podem ter valores de emissividade próximos de 0.95 . A emissividade do aço polido é $0,4{ }^{[72]}$ 
com tinta preta resistente a alta temperatura (até $600^{\circ} \mathrm{C}$ ), porém com o progresso do ensaio a tinta queima e contamina uma grande área do corpo de prova, fazendo com que seja difícil manter a metodologia de acompanhar o progresso do ensaio sempre na mesma região de medição da temperatura. No corpo de prova ARG3, foi feita outra tentativa, desta vez realizando o primeiro ciclo sob a presença de oxigênio, apenas para modificar levemente a coloração da superfície e facilitar a leitura do pirômetro. Os demais ciclos foram feitos sob argônio. Não se sabe o quanto a camada de óxido formada em apenas 1 ciclo pode influenciar na formação de trincas térmicas, porém Gell e Leverant ${ }^{[73]}$ fizeram alguns testes em ensaios de fadiga a quente, variando a atmosfera (úmida/seca) ou sob vácuo, com ou sem pré-oxidação, e chegaram à conclusão de que as amostras pré-oxidadas, ensaiadas no vácuo, têm o mesmo comportamento das amostras polidas, sob vácuo.

- Apesar das vedações na caixa de ensaio feita de acrílico, não foi possível avaliar se foi completamente eliminada a presença de ar na câmara, que pode ser desprendido de possível umidade adsorvida nas paredes, suportes ou no corpo de prova, ou de pequenas bolhas de ar que possam escapar pela região de montagem do corpo de prova com as mangueiras.

- O critério de falha não poderia ser o de vazamento de água, pois causaria contaminação da superfície, portanto o critério utilizado para interrupção do ensaio foi uma trinca visível a olho nu durante o aquecimento.

As Figuras 4.40, 4.41 e 4.42 mostram o avanço do dano nos corpos de prova ensaiados na condição ARG. Os carbonetos permaneceram brilhantes, sem oxidação, durante todos os ensaios. 


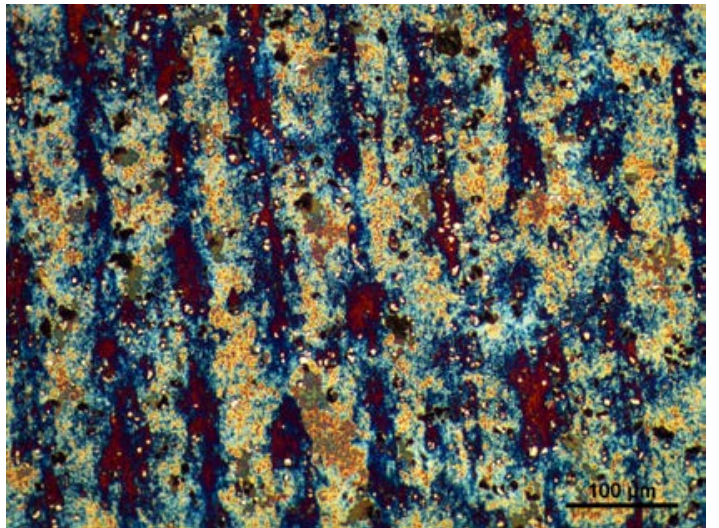

(a)

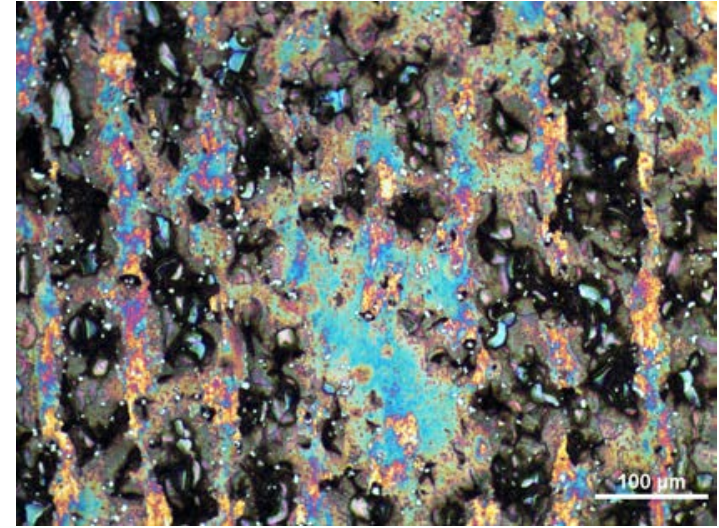

(b)

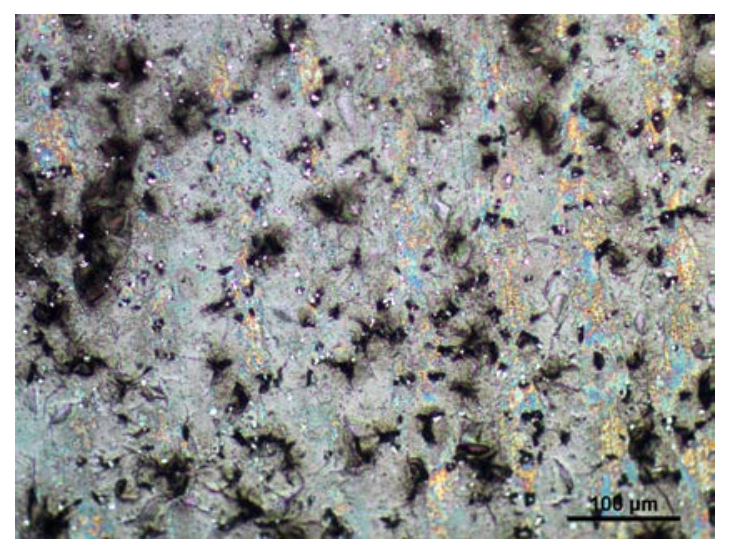

(c)

Figura 4.40: Evolução do dano superficial do corpo de prova ARG1. (a) Após 1000 ciclos, a coloração da superfície mudou como indício de início de oxidação. O padrão em forma de listras ainda não pôde ser explicado; (b) Após 2000 ciclos, o padrão de listras começa a se desfazer; (c) Após 3000 ciclos, há uma fina camada depositada sobre a superfície, mas com características diferentes da camada de óxido formada nos ensaios ao ar.

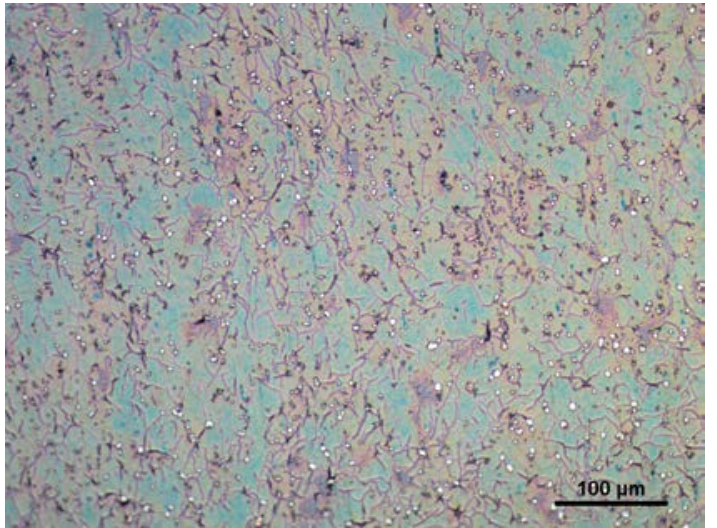

(a)

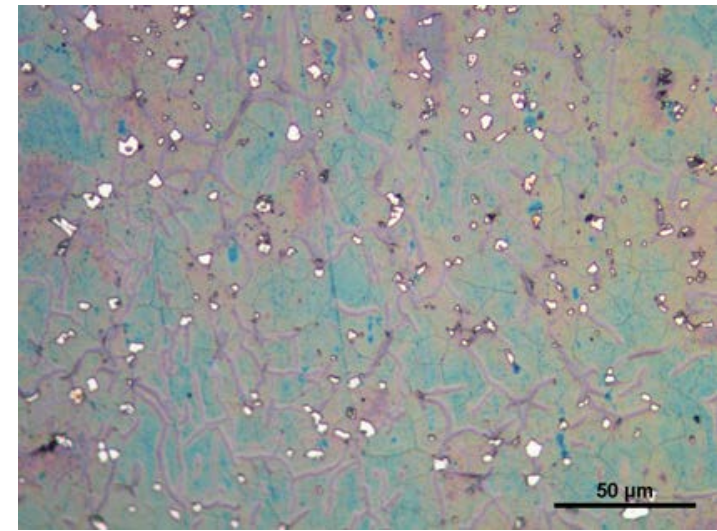

(b)

Figura 4.41: Evolução do dano superficial do corpo de prova ARG2 após 500 ciclos. A fina camada formada na superfície tem pontos de início de descamação em forma de veios que se assemelham a trincas, mas que não foram consideradas trincas na medição de densidade de trincas secundárias.

É possível visualizar os contornos de grão do material. (a) 200x; (b) 500x. 


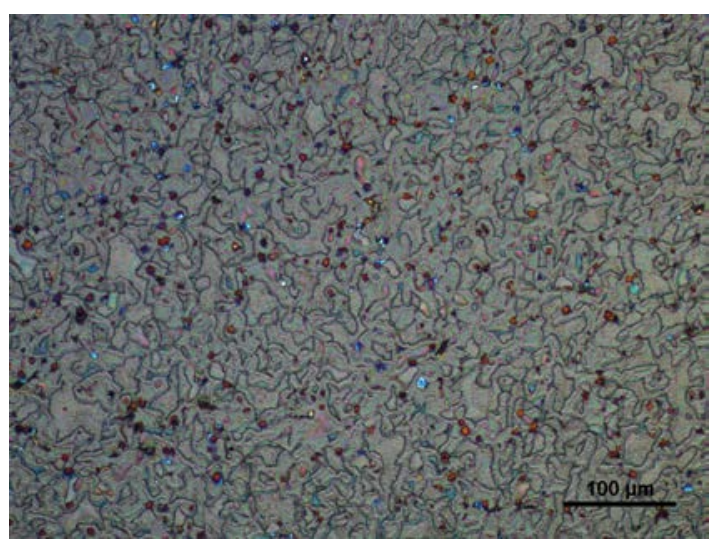

(a)

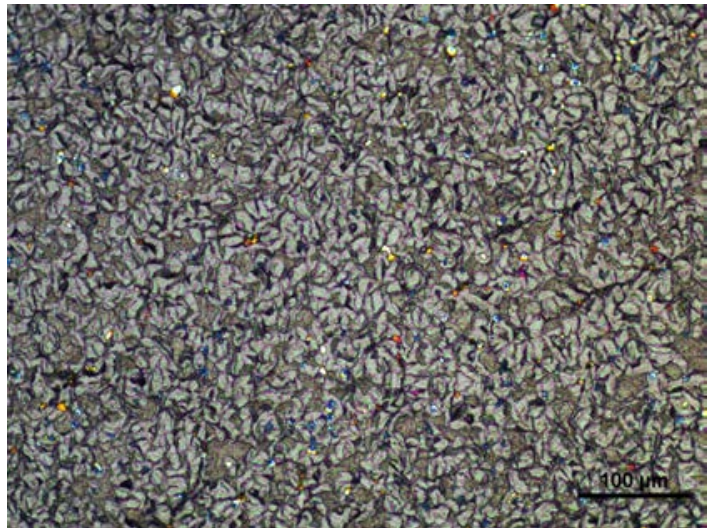

(b)

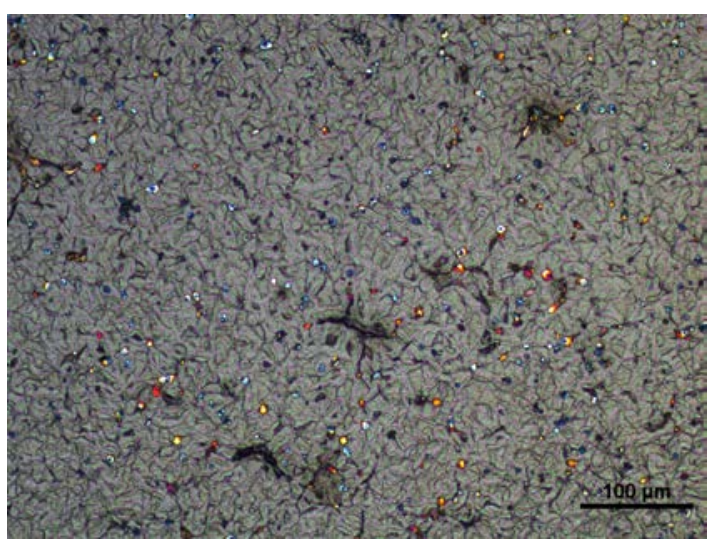

(c)

Figura 4.42: Evolução do dano superficial do corpo de prova ARG3. (a) Após 1000 ciclos, a superfície possui uma camada parcialmente aderida à superfície, que se destaca e cai quando surgem finas trincas; (b) 2000 ciclos; (c) 3000 ciclos, ainda com a mesma formação de camada na superfície. A forma desta camada superficial parece ser a evolução da formação mostrada na Figura 4.41. 
A Figura 4.43 mostra as medidas de densidade de trincas secundárias nos CPs ARG1, ARG2 e ARG3.

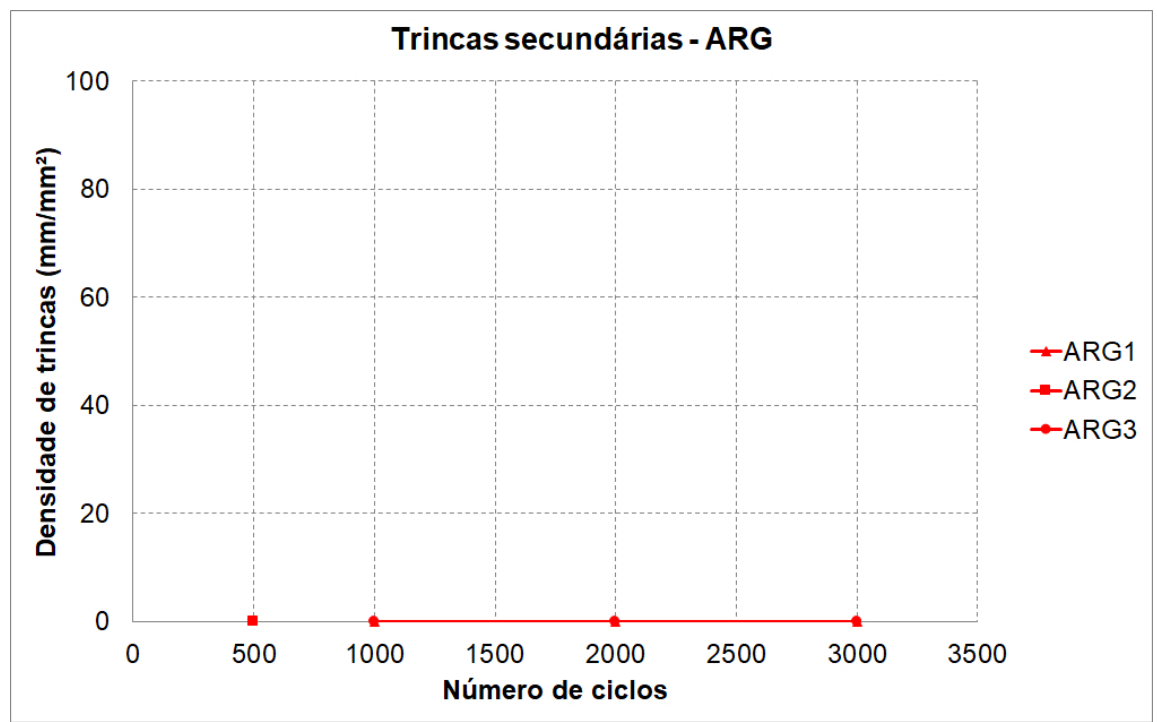

Figura 4.43: Medidas de densidade de trincas secundárias nas amostras ensaiadas na condição ARG.

Quanto à vida média dos corpos de prova, levando-se em conta que o critério de falha para a condição ARG precisou ser adiantado para evitar vazamentos de água, pode-se dizer que mantiveram-se valores semelhantes às demais condições de ensaio a $600^{\circ} \mathrm{C}$. Quanto ao modo de falha, apesar de não haver malha de trincas secundárias, não foi contido o avanço das trincas primárias, que nuclearam em defeitos do material, como a que se vê na Figura 4.42c. No corpo de prova ARG1, a trinca primária nucleou na parte de trás (Figura 4.44), o que não permitiu o seu acompanhamento desde o início do ensaio. 


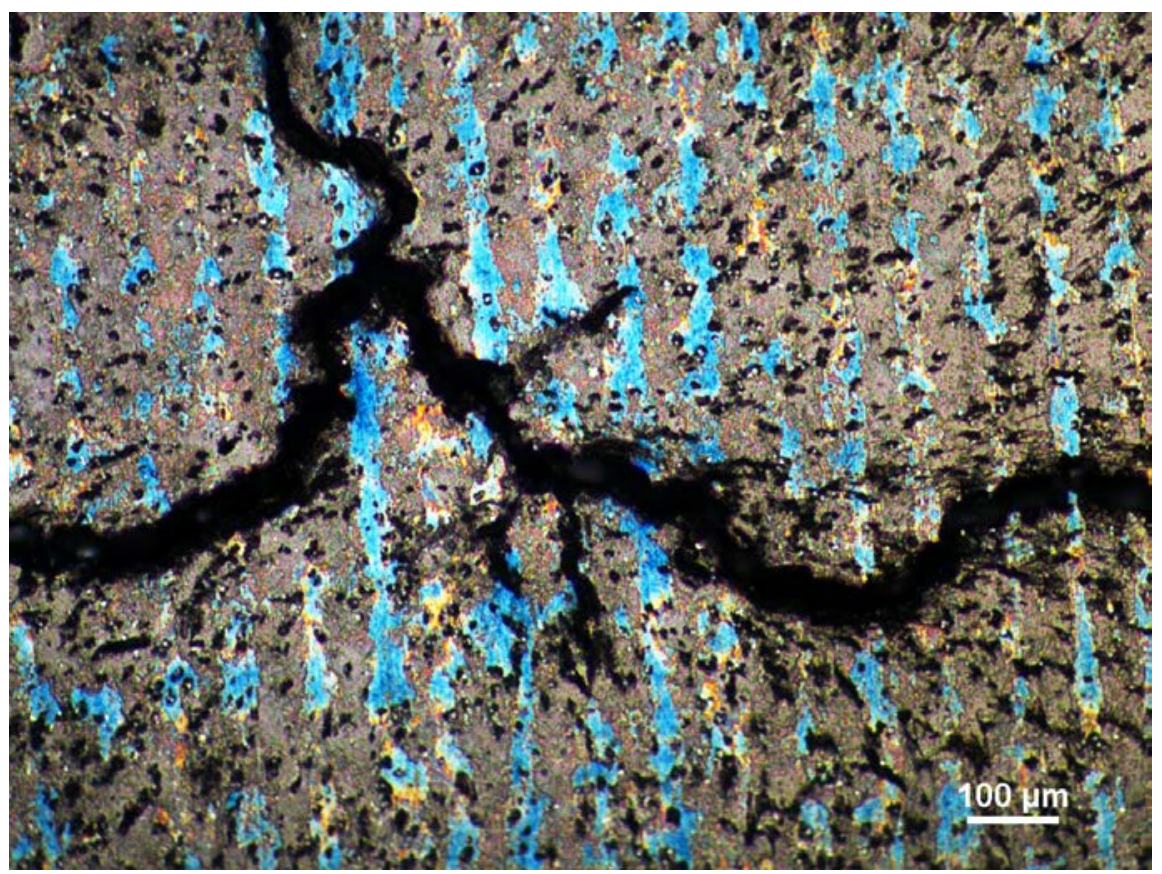

Figura 4.44: Trinca primária nucleada na parte de trás do corpo de prova ARG1 sobre um defeito de fundição. 


\subsubsection{Comparação entre as condições de ensaio}

A Tabela 4.2 apresenta uma compilação dos valores de temperatura máxima e mínima, tempo de aquecimento e resfriamento, velocidade de aquecimento e resfriamento e tempo acima de $400^{\circ} \mathrm{C}$, para cada condição de ensaio, por ciclo.

Tabela 4.2: Valores de temperatura máxima e mínima, tempo de aquecimento e resfriamento, velocidade de aquecimento e resfriamento e tempo acima de $400^{\circ} \mathrm{C}$, para cada condição de ensaio, por ciclo.

\begin{tabular}{l|c|c|c}
\hline Condição de ensaio & REF & HOT & LOW \\
\hline Temperatura máxima $\left({ }^{\circ} \mathrm{C}\right)$ & 610,41 & 661,79 & 604,18 \\
Tempo de aquecimento $(\mathrm{s})$ & 1,16 & 1,59 & 2,27 \\
Taxa de aquecimento $\left({ }^{\circ} \mathrm{C} / \mathrm{s}\right)$ & 433,74 & 347,84 & 218,09 \\
Temperatura mínima $\left({ }^{\circ} \mathrm{C}\right)$ & 109,44 & 110,46 & 110,21 \\
Tempo de resfriamento $(\mathrm{s})$ & 14,52 & 17,17 & 17,62 \\
Taxa de resfriamento $\left({ }^{\circ} \mathrm{C} / \mathrm{s}\right)$ & $-34,50$ & $-32,12$ & $-28,04$ \\
Tempo acima de $400{ }^{\circ} \mathrm{C}\left(\mathrm{s} / \mathrm{Ciclo}^{*}\right)$ & 1,31 & 2,51 & 3,07 \\
\hline * segundos, por ciclo &
\end{tabular}

As principais diferenças macroscópicas observadas nos corpos de prova ensaiados na condição LOW, com menor velocidade de aquecimento em comparação à condição REF, e REV, de menor dureza, estão na densidade de trincas secundárias, como era previsto por Medjeboub e Rézaï-Aria ${ }^{[3,49]}$, e na posição de formação e quantidade das trincas primárias. Na condição LOW, as trincas formaram-se na região do pescoço do corpo de prova, enquanto as demais nuclearam no centro da região aquecida, da forma esquematizada na Figura 4.45. Na condição REV, houve um número significativamente maior de trincas primárias.

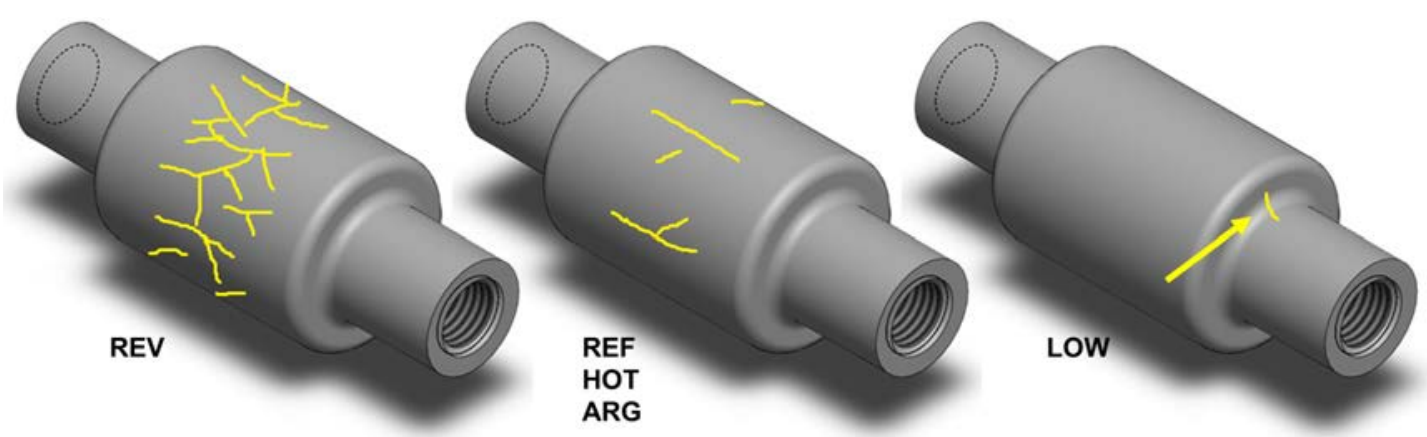

Figura 4.45: Posição típica de afloramento das trincas primárias (macrotrincas) quando ensaiadas na condição REV (esquerda), REF, HOT e ARG (centro) e LOW (direita).

A propagação das trincas primárias segue os caminhos entre carbonetos, 
passando pela malha de trincas secundárias formada anteriormente, assim como se vê na Figura 4.46.

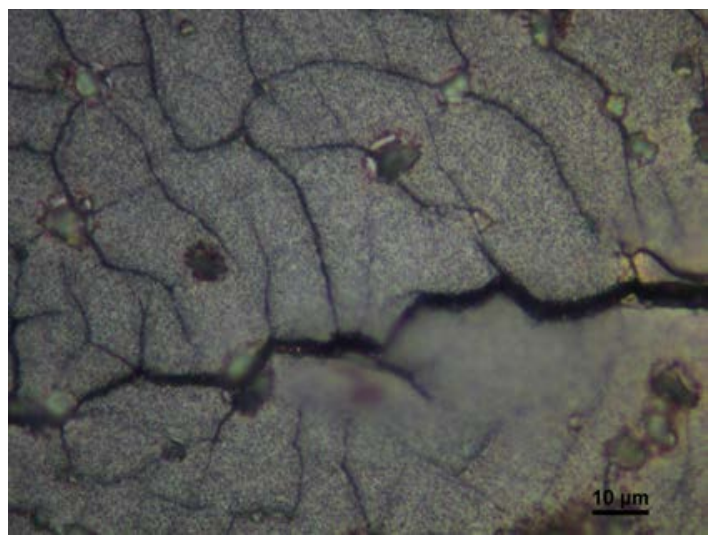

(a)

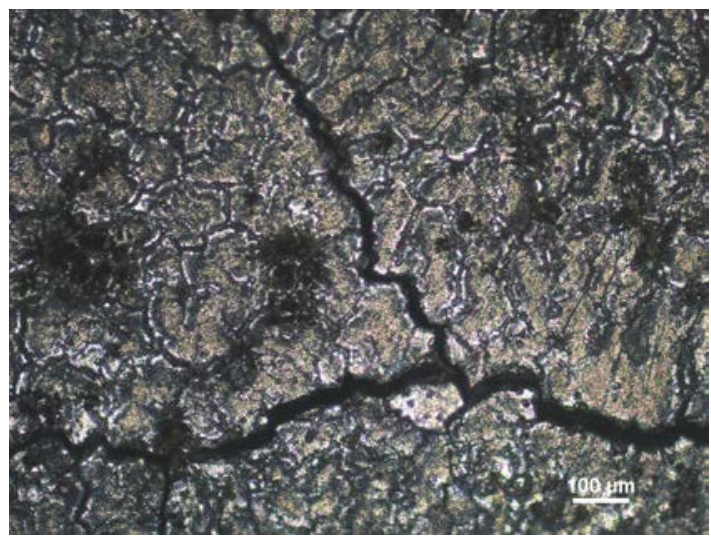

(b)

Figura 4.46: Caminho de propagação pela superfície de trincas primárias.

(a) Ponta da trinca, passando por carbonetos, através da malha secundária;

(b) Ponto de ramificação, com trincas propagando sempre através da malha secundária.

Unindo-se todos os gráficos de evolução da densidade de trincas secundárias nas 5 condições de ensaio (resumidas na Figura 3.17), é possível comparar o efeito da variação dos parâmetros de aquecimento, material e atmosfera no tempo de vida dos corpos de prova (Figura 4.47).

Como se pode ver na Figura 4.47, a maioria dos corpos de prova ensaiados a $600^{\circ} \mathrm{C}$ suportou cerca de 3000 a 4000 ciclos antes de falhar, enquanto o ensaio a $650^{\circ} \mathrm{C}$ (HOT) acelerou o dano e fez a vida cair para menos de 1000 ciclos. A densidade de trincas secundárias foi semelhante para os corpos de prova ensaiados ao ar em velocidade alta (que, por sinal, também é igual à densidade de trincas estável atingida no ensaio preliminar - Figura 4.18), e menor para os corpos de prova da condição em velocidade baixa (LOW).

A presença de defeitos de fundição foi determinante no início da formação de trincas primárias, porém não foi o único mecanismo que causou as falhas. O efeito da presença de defeitos pode ser observado na figura comparandose o tempo de vida dos corpos de prova ensaios em condições iguais. CPs que tiveram a vida abreviada, em relação à evolução normal do dano, também foram diagnosticados com defeitos de fundição. 


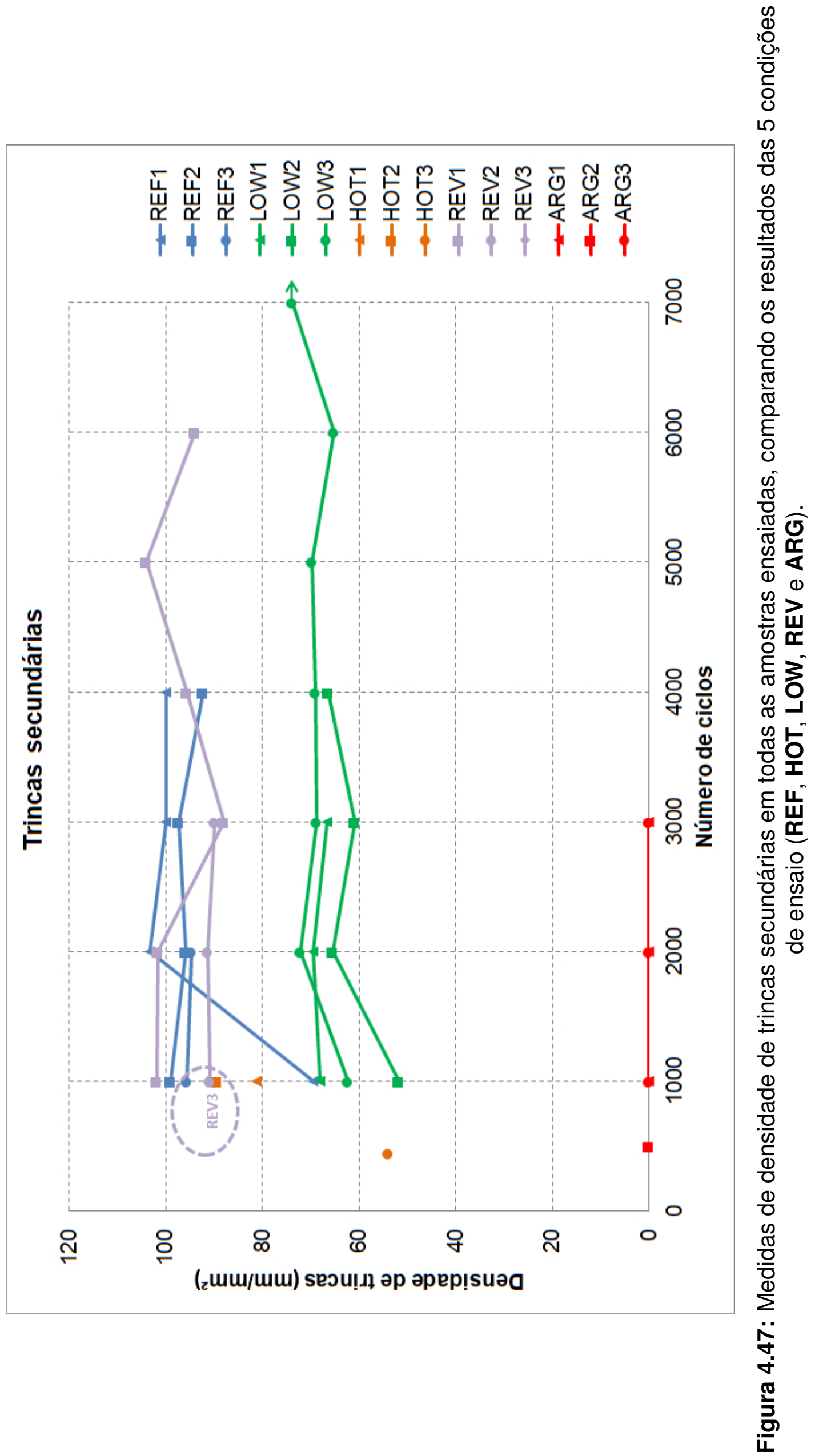




\subsubsection{Caracterização da seção transversal}

O objetivo de caracterizar a seção transversal dos corpos de prova ensaiados não foi medir quantidade e profundidade das trincas, mas buscar compreender a morfologia das trincas secundárias e quais os mecanismos envolvidos na nucleação e propagação de uma trinca primária a partir da malha secundária. Além disso, utilizou-se a seção transversal para avaliar o amolecimento devido ao revenimento sofrido pela superfície aquecida através de perfis de microdureza.

A preparação da seção transversal foi feita, depois de cortada uma fatia circular do corpo de prova, por embutimento, lixamento e polimento. A face preparada foi o plano do centro do corpo de prova, a mesma região onde foi feito o acompanhamento das trincas superficiais.

\subsubsection{MO}

Como já tinha sido constatado na análise das superfícies, os pontos de formação de defeitos de fundição são os mais críticos para aparecimento de trincas primárias. Quando os defeitos afloram para a superfície, são um ponto de alta concentração de tensões e de oxidação, tornando-se pontos frágeis da estrutura. O defeito de fundição mais comum, encontrado em todas as amostras, foi inclusão de filme de óxido, causado por turbulência durante o lingotamento ${ }^{[74]}$, como mostra a Figura 4.48.

Quanto à malha de trincas secundárias em regiões livres de defeitos, o que se observa abaixo da superfície varia de acordo com a condição de ensaio. No Plano de Trabalho (pág. 75) foram feitas algumas considerações sobre o efeito das condições de aquecimento sobre a oxidação da superfície. Foi dito que as condições HOT e LOW favorecem o aumento da oxidação devido, respectivamente, ao aumento da temperatura e do tempo de exposição à alta temperatura. Nos ensaios de oxidação estática, isso foi confirmado pela medição de espessura da camada de óxido. Já nos ensaios de fadiga térmica, com a quebra da camada de óxido causada pelas tensões, nota-se uma relação direta do número e profundidade dos pontos de oxidação preferencial na interface metal/óxido com as condições de oxidação (Figura 4.49).

É nítido o aumento do número e da profundidade dos pontos de oxidação preferencial (Vs) nas amostras da condição HOT (Figura 4.49b) e LOW (Figura 4.49c), em comparação à referência. Na amostra revenida, a forma- 


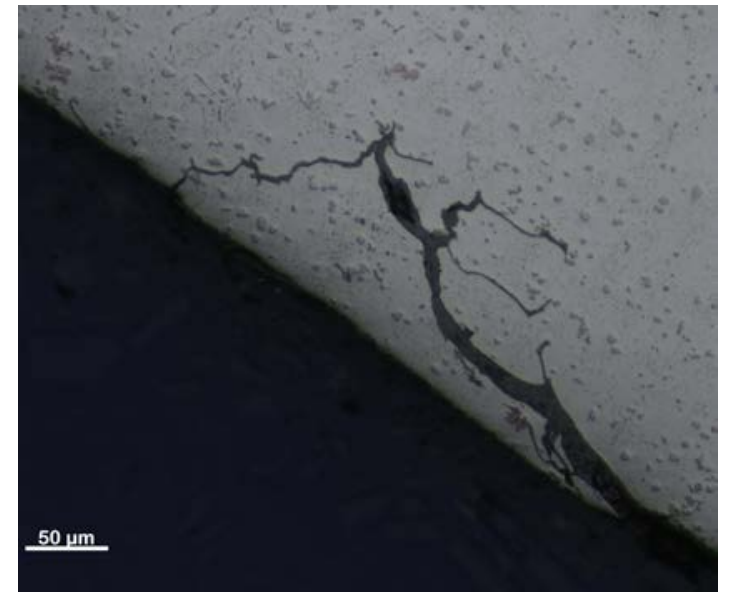

(a)

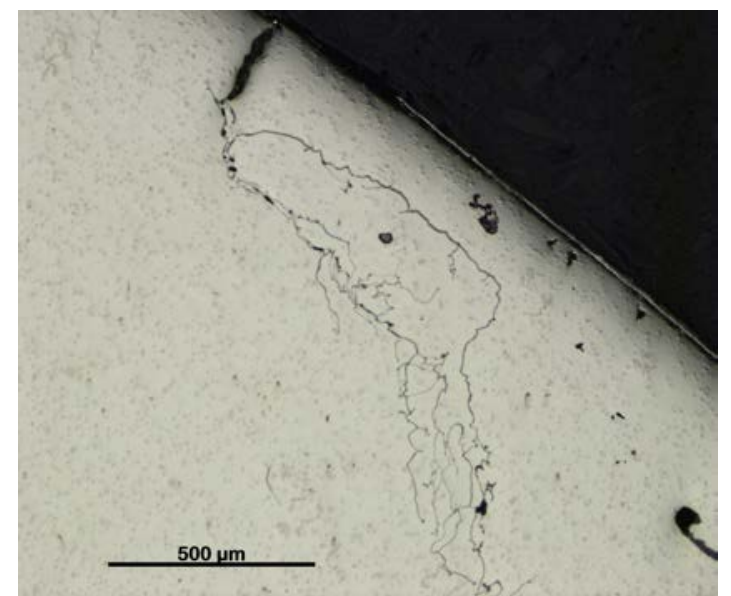

(c)

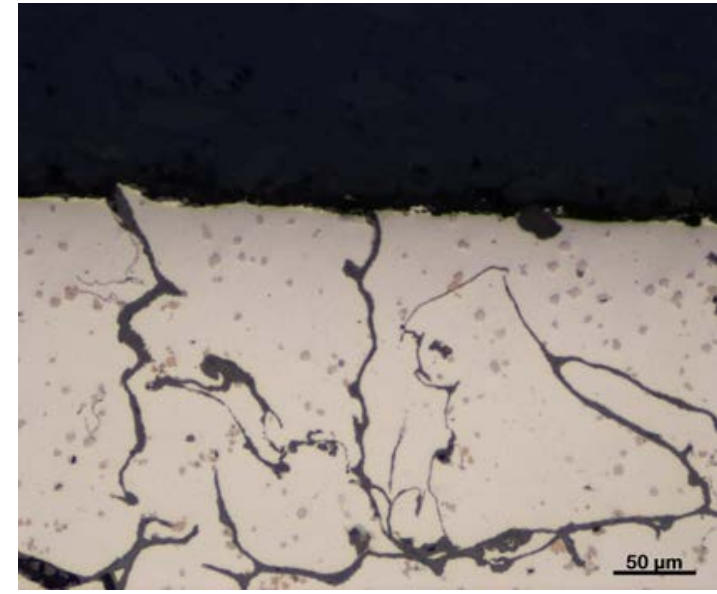

(b)

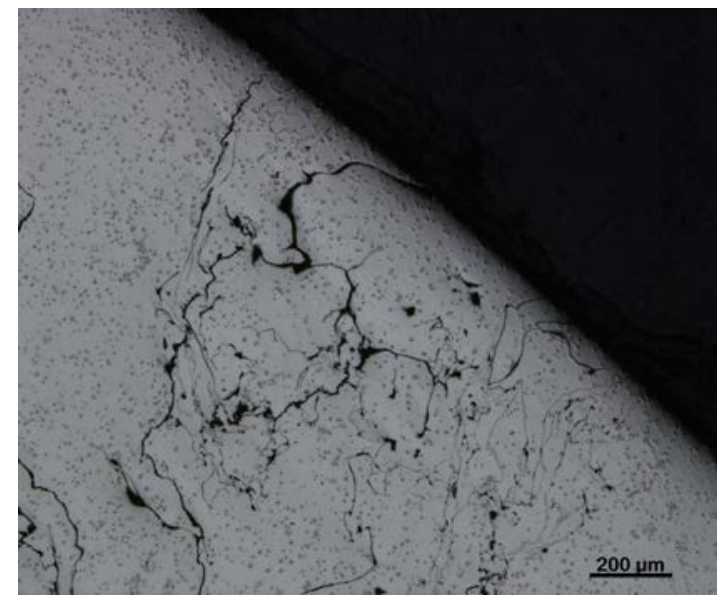

(d)

Figura 4.48: Pontos de nucleação de trincas primárias causadas por defeitos de fundição.

ção de Vs é ainda menor, provavelmente causada pela oxidação preferencial nas trincas primárias que estão em maior número, como se vê na Figura 4.49d. Na amostra ensaiada sob argônio, como era de se esperar, não foram encontrados Vs; as trincas superficiais, quando ocorrem, nucleiam em defeitos de fundição ou em sulfetos.

As amostras ensaiadas na condição LOW não tinham trincas primárias aflorando para a superfície. Nas regiões analisadas, como por exemplo a da Figura 4.50 foram visualizadas apenas trincas que nucleavam na parede interna do furo e propagavam em direção à superfície.

O número de ocorrências de trincas primárias na seção transversal nas amostras ensaiadas na condição REV é maior que nas demais condições, como já foi mostrado (Figura 4.37). Foram vistos também alguns pontos de perda de massa causados pela conexão de pelo menos duas trincas no interior do material (Figura 4.38). A aparência dessas trincas na seção trans- 


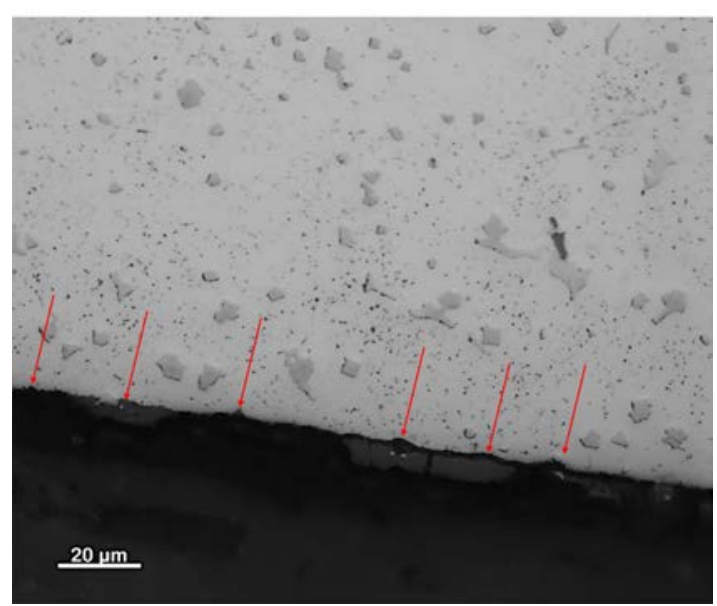

(a)

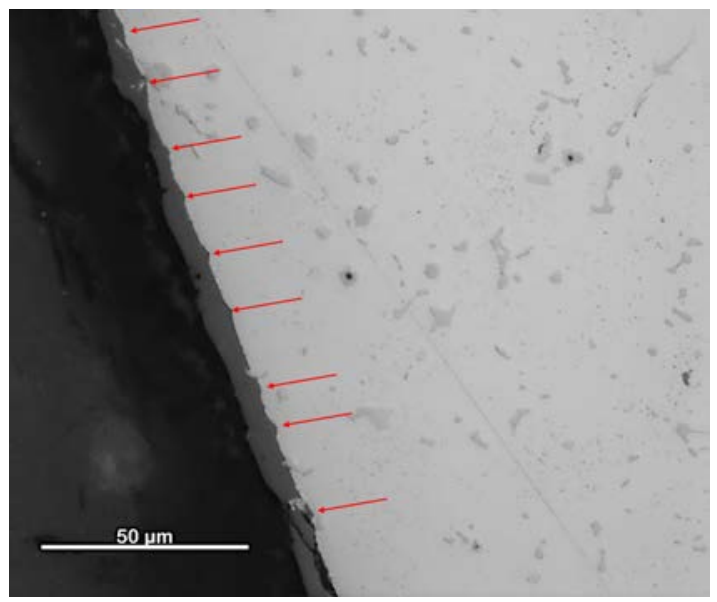

(c)

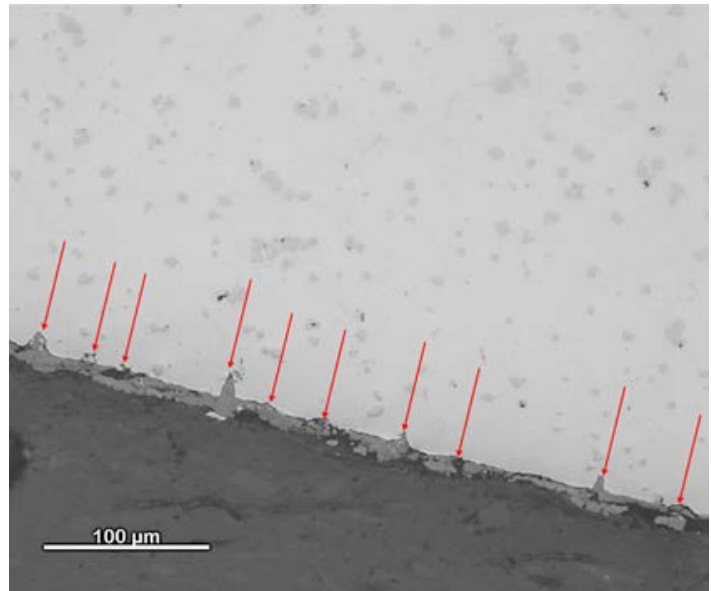

(b)

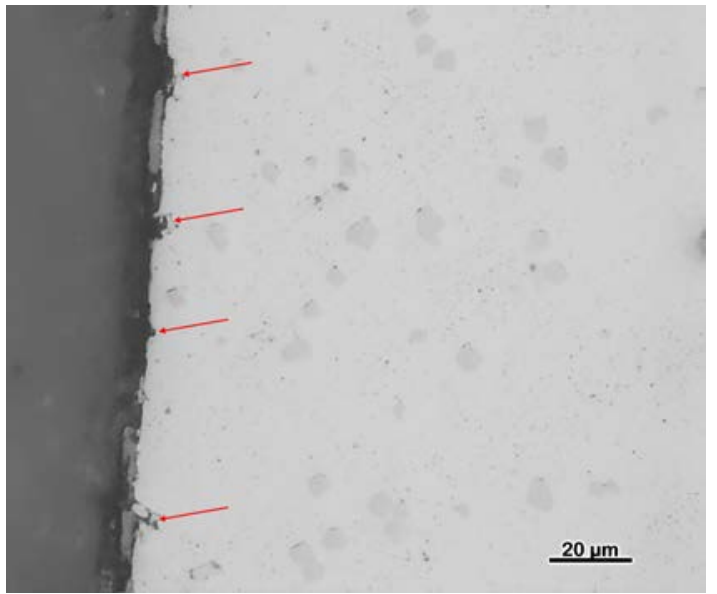

(d)

Figura 4.49: Pontos de oxidação preferencial (indicados por setas) na interface matriz/óxido nos pontos abaixo das trincas secundárias. (a) Condição REF; (b) HOT; (c) LOW; (d) REV.

versal pode ser vista na Figura 4.51, sendo que a Figura 4.51a mostra duas trincas nucleando lado a lado e propagando em direção perpendicular à superfície, conectando os carbonetos de nióbio. A Figura 4.51b mostra uma região onde trincas primárias se conectaram e causaram perda de massa por arrancamento. Não foi vista, nos corpos de prova revenidos, nenhuma trinca passante da superfície externa para a interna, o que indica que o revenimento aumentou a resistência do material à propagação de trincas, ou seja, causou aumento do $\mathrm{K}_{I c}$.

Quando atacadas, novamente se confirmou que os pontos preferenciais para oxidação são as interfaces carboneto/matriz e os contornos de grão da matriz (Figura 4.52). 


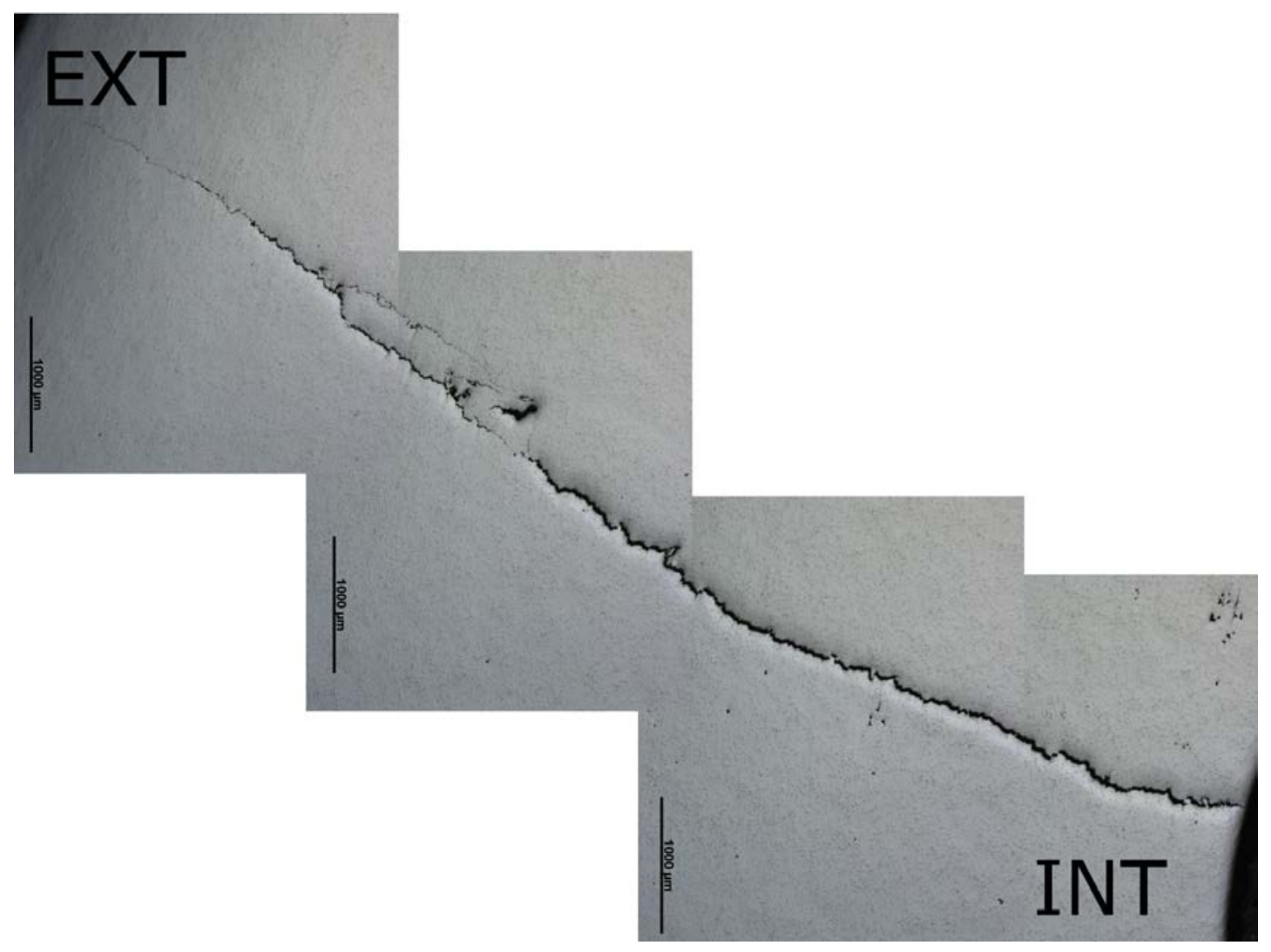

Figura 4.50: Trinca primária na amostra LOW1, nucleando na parede interna do furo, propagando até perto da superfície. A trinca passa próxima a alguns defeitos do material.

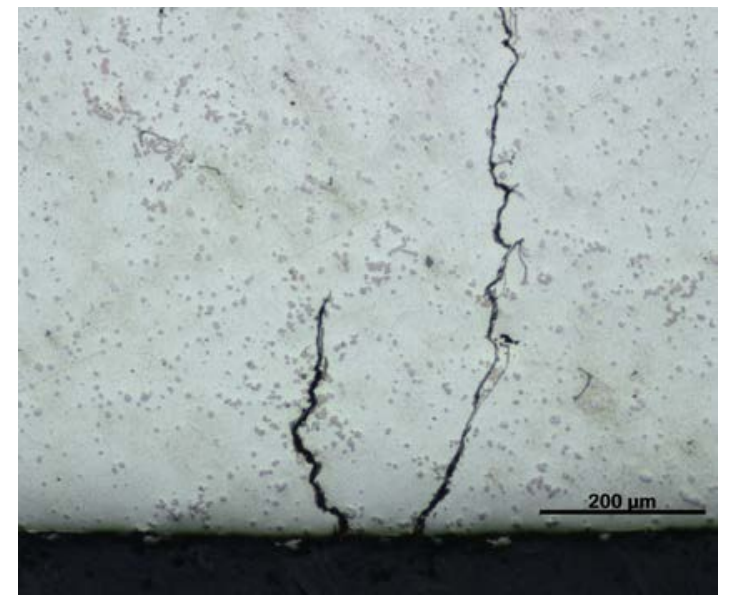

(a)

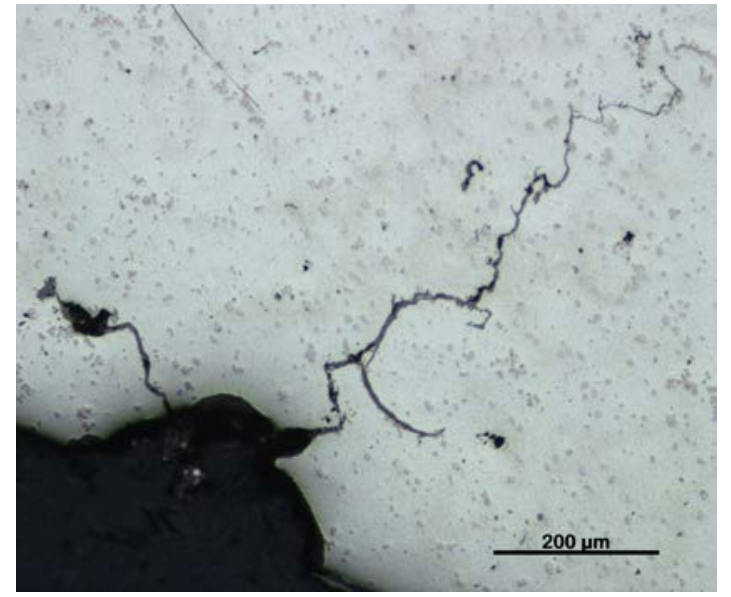

(b)

Figura 4.51: Trincas primárias na amostra REV3. (a) Trincas nucleando na superfície e propagando através da matriz, conectando os carbonetos $\mathrm{NbC}$; (b) Região de perda de massa causada por conexão de pelo menos 2 trincas no interior do material. 


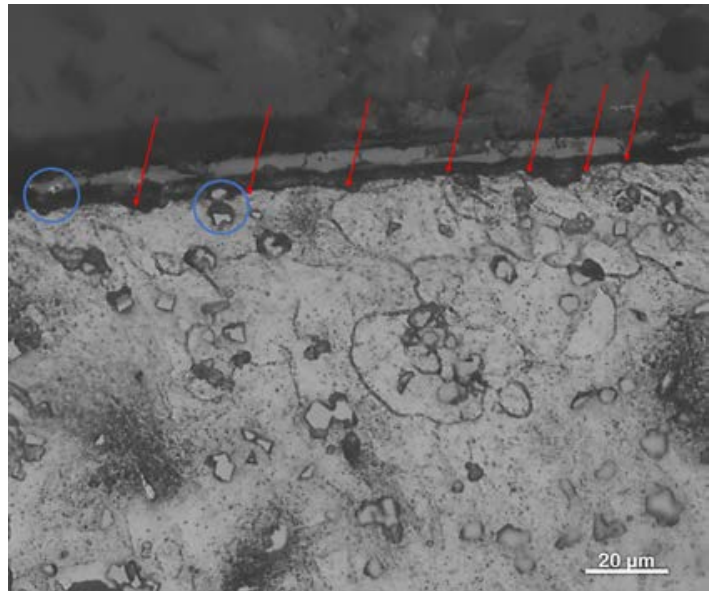

(a)

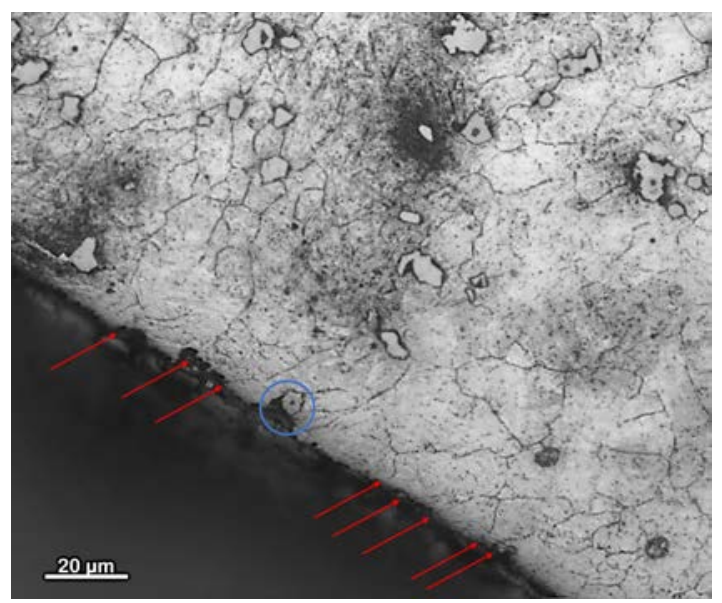

(c)

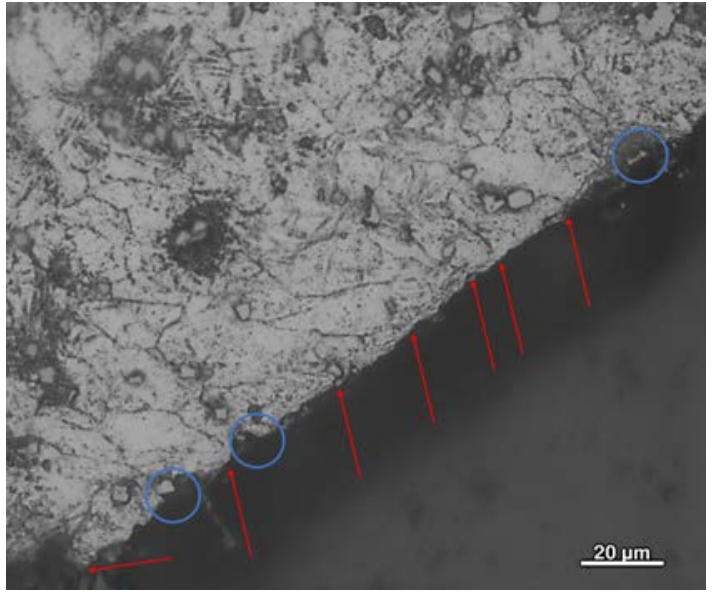

(b)

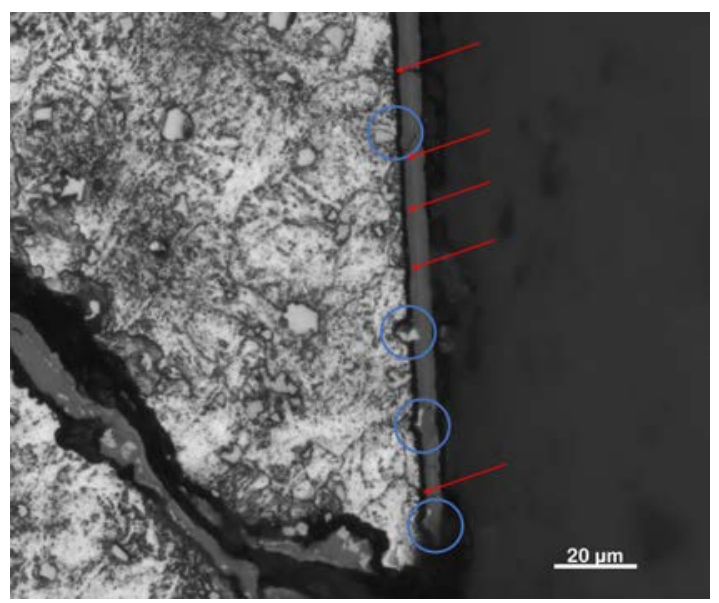

(d)

Figura 4.52: Pontos de oxidação preferencial em interfaces carboneto/matriz (círculos azuis) e contornos de grão da matriz (setas vermelhas) das amostras ensaiadas. Ataque: ácido pícrico + detergente a $60^{\circ} \mathrm{C}$. Aumento: 500x. (a) Condição REF; (b) HOT; (c) LOW; (d) REV. 


\subsubsection{MEV}

As amostras REF1 e ARG2 foram levadas ao microscópio eletrônico de varredura para observação da região próxima da superfície e medições de composição química semiquantitativa por EDS em regiões de interesse, como óxidos formados na superfície, inclusões e partículas de segunda fase.

A Figura 4.53 mostra a formação de óxido sobre a superfície do corpo de prova REF1, em seção transversal. Abaixo da trinca, nota-se a formação em $\mathbf{V}$ causada pela oxidação preferencial de uma região específica (provavelmente um contorno de grão). A camada de óxido tem 3 morfologias distintas, embora a morfologia da camada interna não esteja presente em toda a amostra. A composição química das duas camadas internas é bastante parecida, considerando as incertezas em identificação dos picos do espectro e na quantificação dos elementos químicos identificados. A camada externa, entretanto, consiste basicamente de ferro, oxigênio e carbono, embora a análise de carbono deva ser desprezada neste tipo de análise, devido aos erros intrínsecos do tipo de medida e de preparação de amostra.

A Figura 4.54 mostra as análises químicas por EDS feitas sobre dois pontos de um filme de óxido encontrado no corpo de prova REF1. Olhando com aumento suficiente, notam-se duas regiões: um filme escuro central e um filme claro depositado sobre o filme central. O filme escuro possui grande quantidade de oxigênio e contaminação por alumínio, o que sugere que houve inclusão de um filme de óxido durante a fundição, provavelmente causado por turbulência, como disse Campbell ${ }^{[74]}$. Sobre o filme escuro, depositou-se o filme claro, com a mesma composição química dos carbonetos de nióbio presentes no restante da amostra (majoritariamente, $\mathrm{Nb}, \mathrm{C}$ e Ti). Em todas ocorrências de inclusão de filmes encontradas das amostras REF1 e ARG2, a presença e proporção entre os elementos químicos se manteve. 


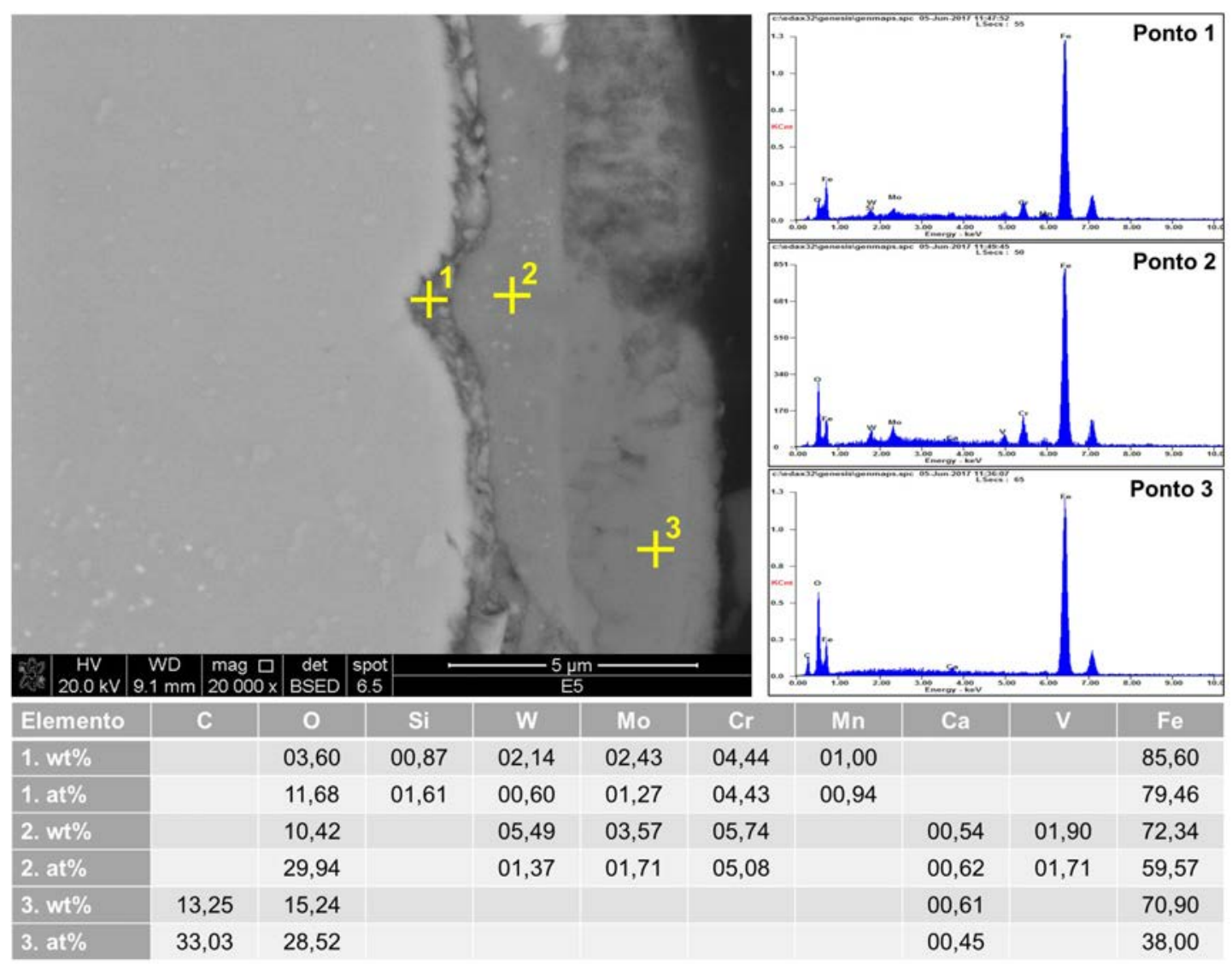

Figura 4.53: Análises de EDS nas camadas de óxido formadas sobre 0 corpo de prova REF1. Pela morfologia, são identificadas 3 camadas. A camada interna, porosa, tem composição química semelhante à camada intermediária. Ambas são ricas em elementos de liga presentes na matriz. A camada externa é pobre em elementos de liga, detectando-se apenas $\mathrm{Fe}, \mathrm{C}$ (duvidoso) e $\mathrm{O}$. 


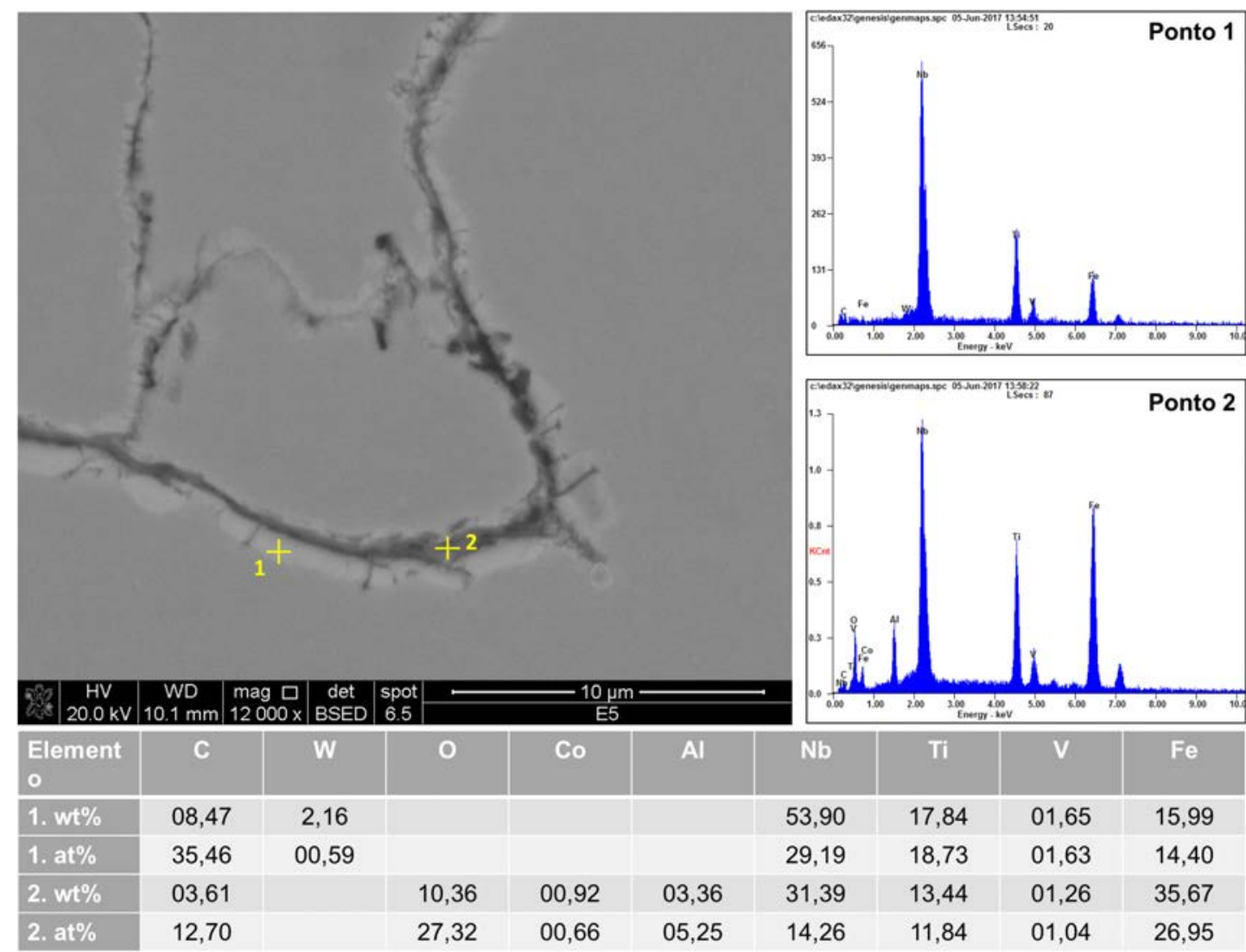

Figura 4.54: Análises de EDS em uma inclusão de filme de óxido. Nota-se um filme central formado por óxido de titânio e a formação de um filme de carboneto de nióbio sobre ele.

A camada externa formada sobre os corpos de prova ensaiados sob atmosfera de argônio é bastante fina e de coloração diferente da camada formada quando o ensaio era realizado ao ar. Essa camada só é visível no MEV com grandes aumentos, como na Figura 4.55. Devido à pequena espessura $(<1 \mu \mathrm{m})$, a medição por EDS é bastante imprecisa, pois esse tipo de medida é influenciado pelas regiões vizinhas, que são a matriz metálica e a baquelite. Assim, não é possível pelos métodos utilizados confirmar ou negar a suposição de que tenha havido formação de uma camada de óxido de espessura nanométrica. 


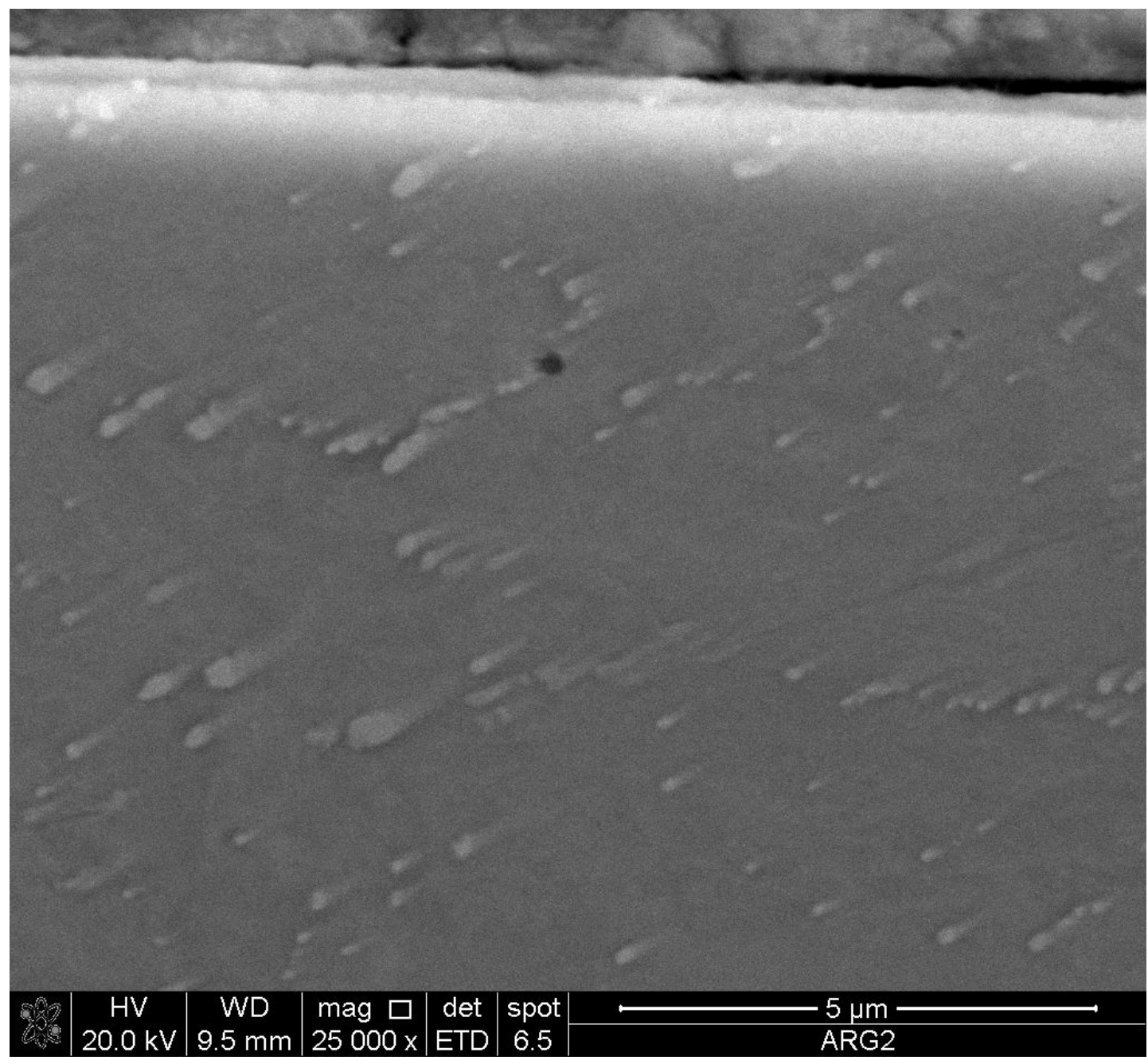

Figura 4.55: Camada de óxido formada sobre o corpo de prova ARG2. A medição por EDS nessa pequena espessura é imprecisa para determinar a sua composição química. 


\subsubsection{Tomografia de raios- $X$}

O motivo de corpos de prova serem analisados por tomografia de raios- $X$ foi buscar uma alternativa para visualizar o lugar de nucleação e o caminho de propagação das trincas primárias ao longo dos corpos de prova, sem a realização de cortes mecânicos ou por eletroerosão, que podem causar alteração na microestrutura, nucleação de novas trincas ou deformação ou propagação das trincas existentes, mascarando o resultado real.

As imagens obtidas por tomografia de raios- $X$ foram suficientes para localização das trincas primárias, porém com baixa resolução. Devido à densidade do aço, à espessura do material e à pequena diferença de densidade entre o metal e as trincas, não é possível ter boa resolução para fazer medições precisas. O método possibilita visualizar as trincas e outras características dos corpos de prova em imagens bi ou tridimensionais, de acordo com o que se deseja observar. Podem ser realizados cortes em profundidades, alturas ou raios especificados, ou pode ser criada uma reconstrução tridimensional do corpo de prova, onde se visualizam as trincas de forma comparável à imagem real.

A seguir, nas Figuras 4.56 a 4.60, são mostradas acima uma fotografia dos corpos de prova medidos no tomógrafo de raios- $\mathrm{X}$ e, abaixo, a reconstrução 3D da medição, com apontamento das trincas vistas nas duas imagens por setas coloridas de cores correspondentes. Essa comparação serve para mostrar que as descontinuidades vistas nas análises realizadas no tomógrafo são, de fato, trincas do material já confirmadas por outros métodos de análise tradicionais. 


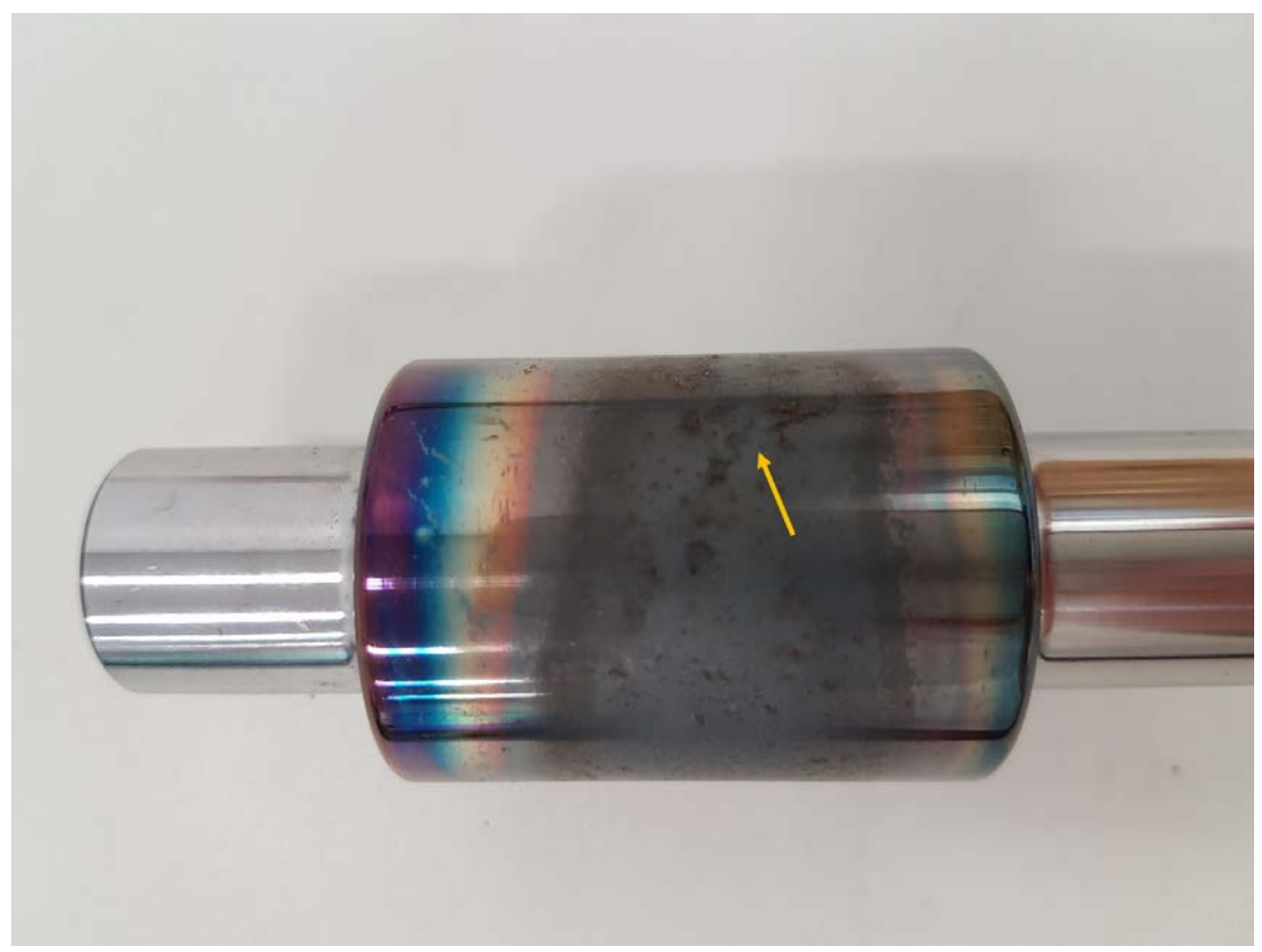

(a)

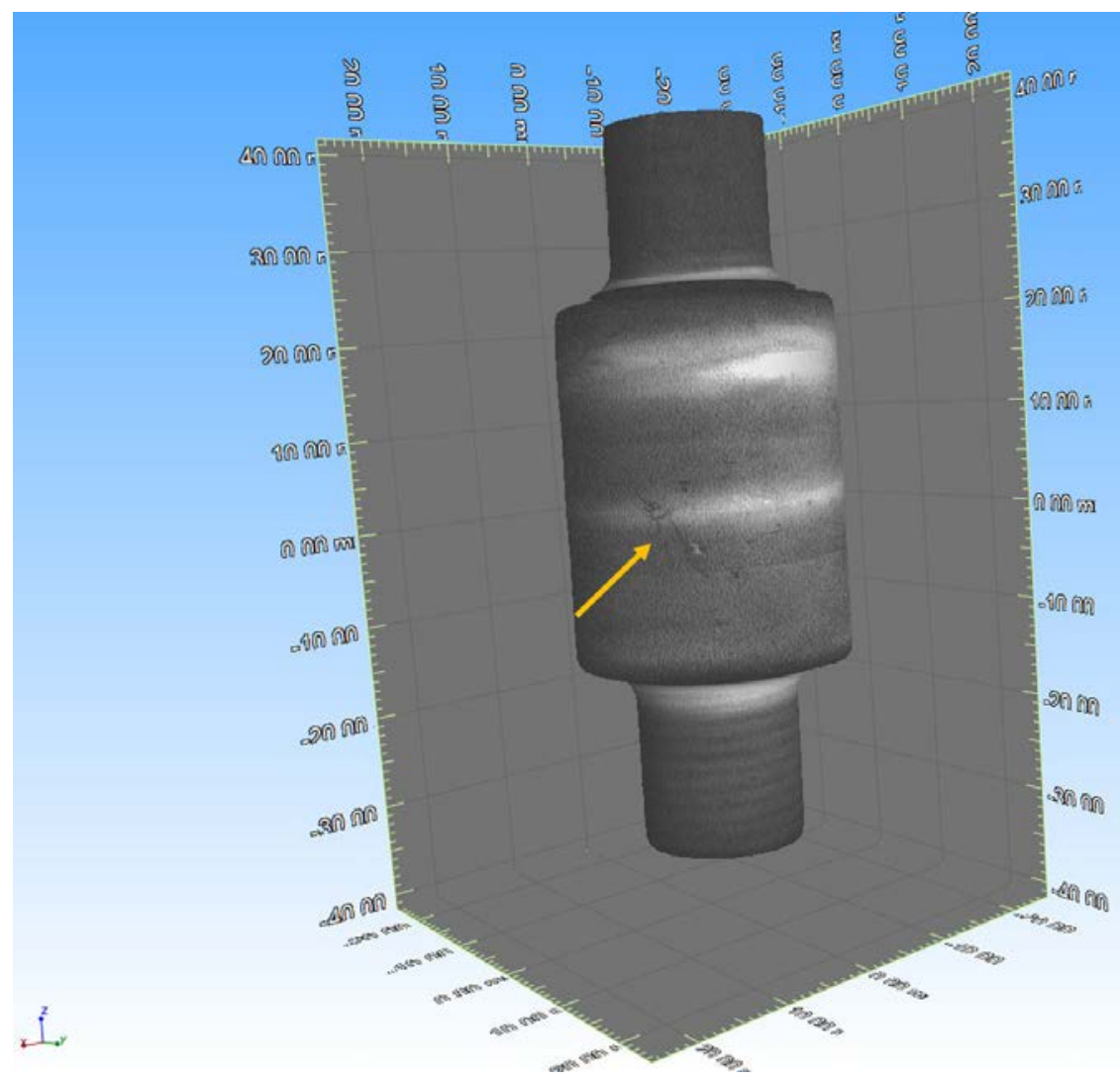

(b)

Figura 4.56: Comparação da amostra REF2 após ensaio e a medição por tomografia de raios-X. (a) Fotografia da superfície; (b) Reconstrução 3D. 


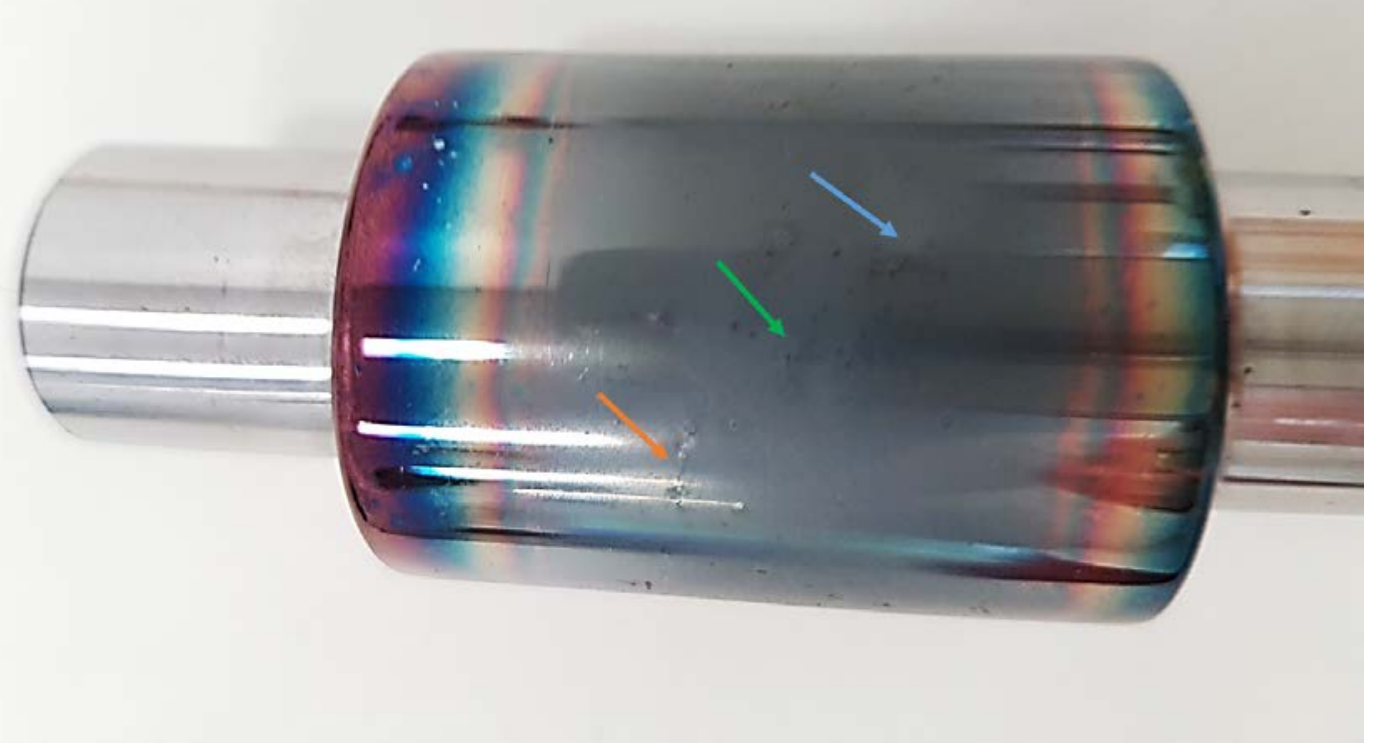

(a)

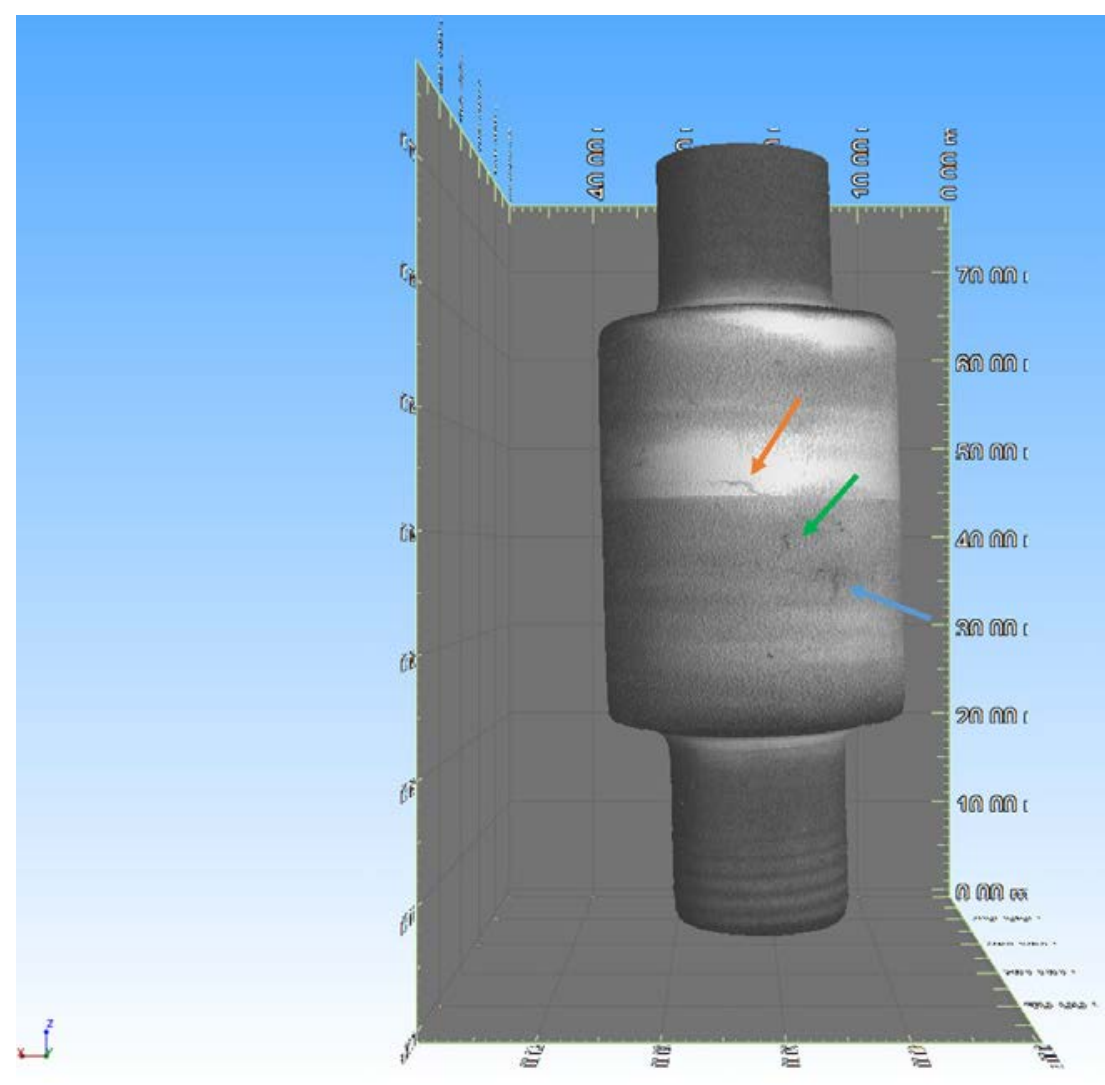

(b)

Figura 4.57: Comparação da amostra HOT2 após ensaio e a medição por tomografia de raios-X (a) Fotografia da superfície; (b) Reconstrução 3D. 


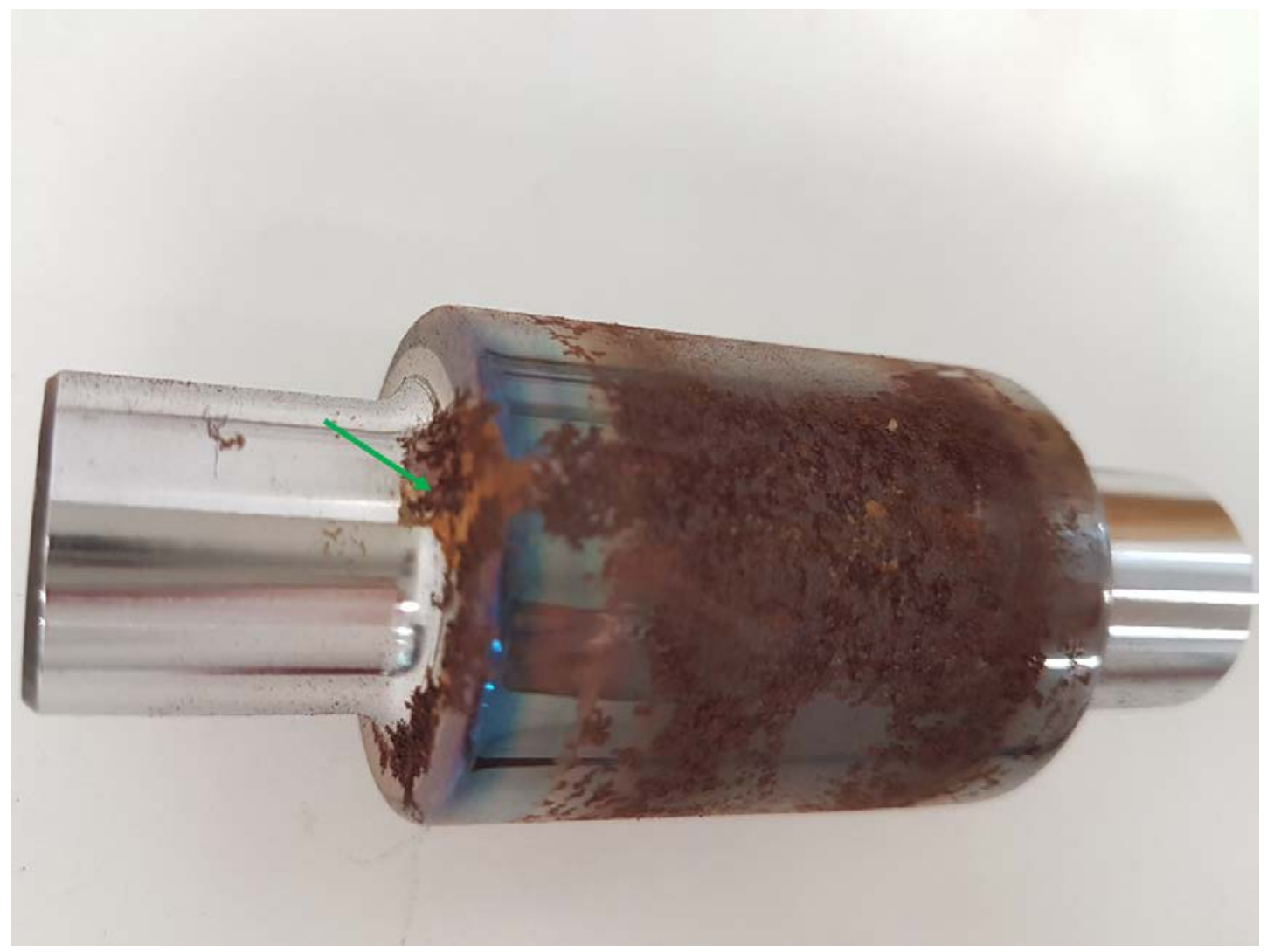

(a)

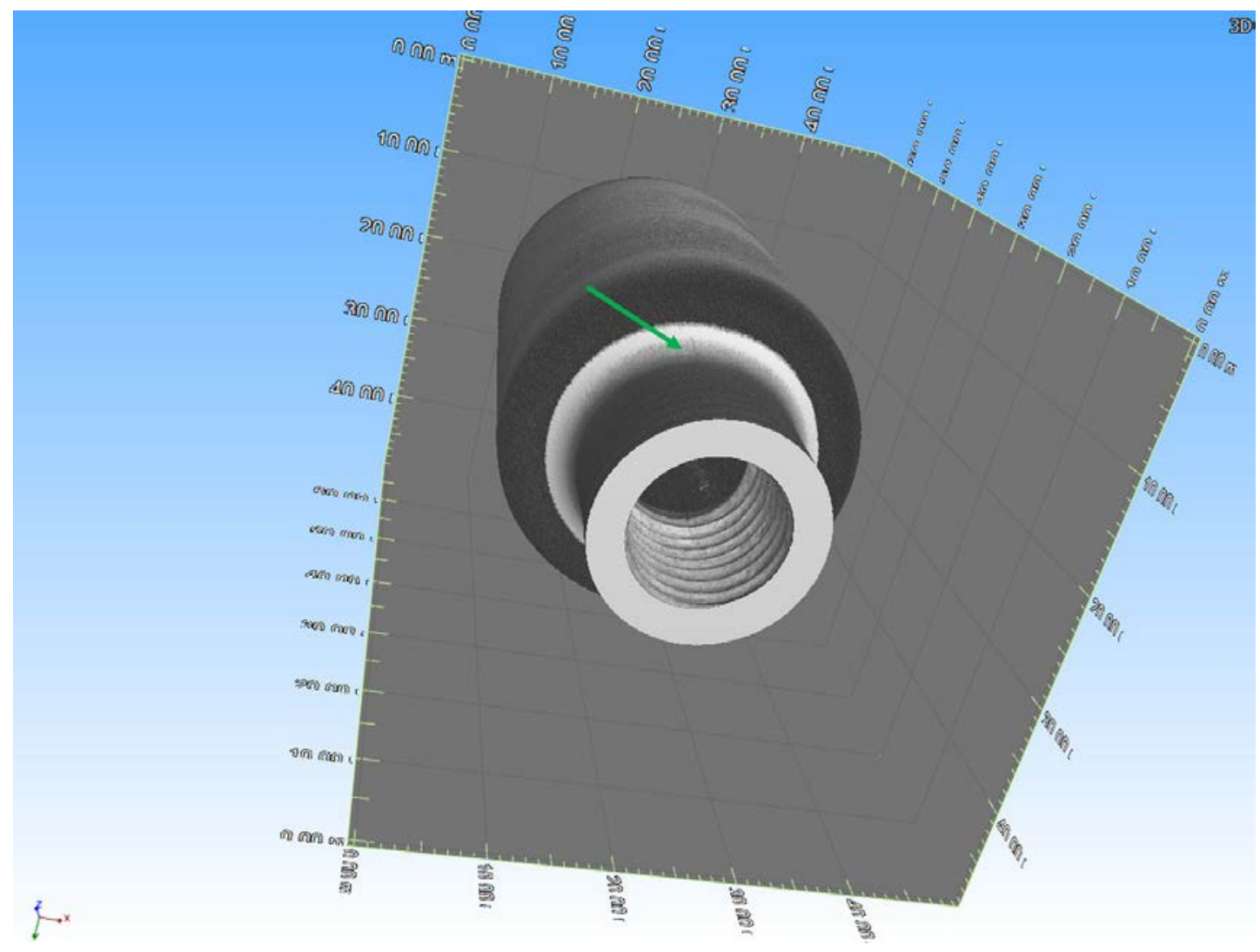

(b)

Figura 4.58: Comparação da amostra LOW2 após ensaio e a medição por tomografia de raios-X (a) Fotografia da superfície; (b) Reconstrução 3D. 


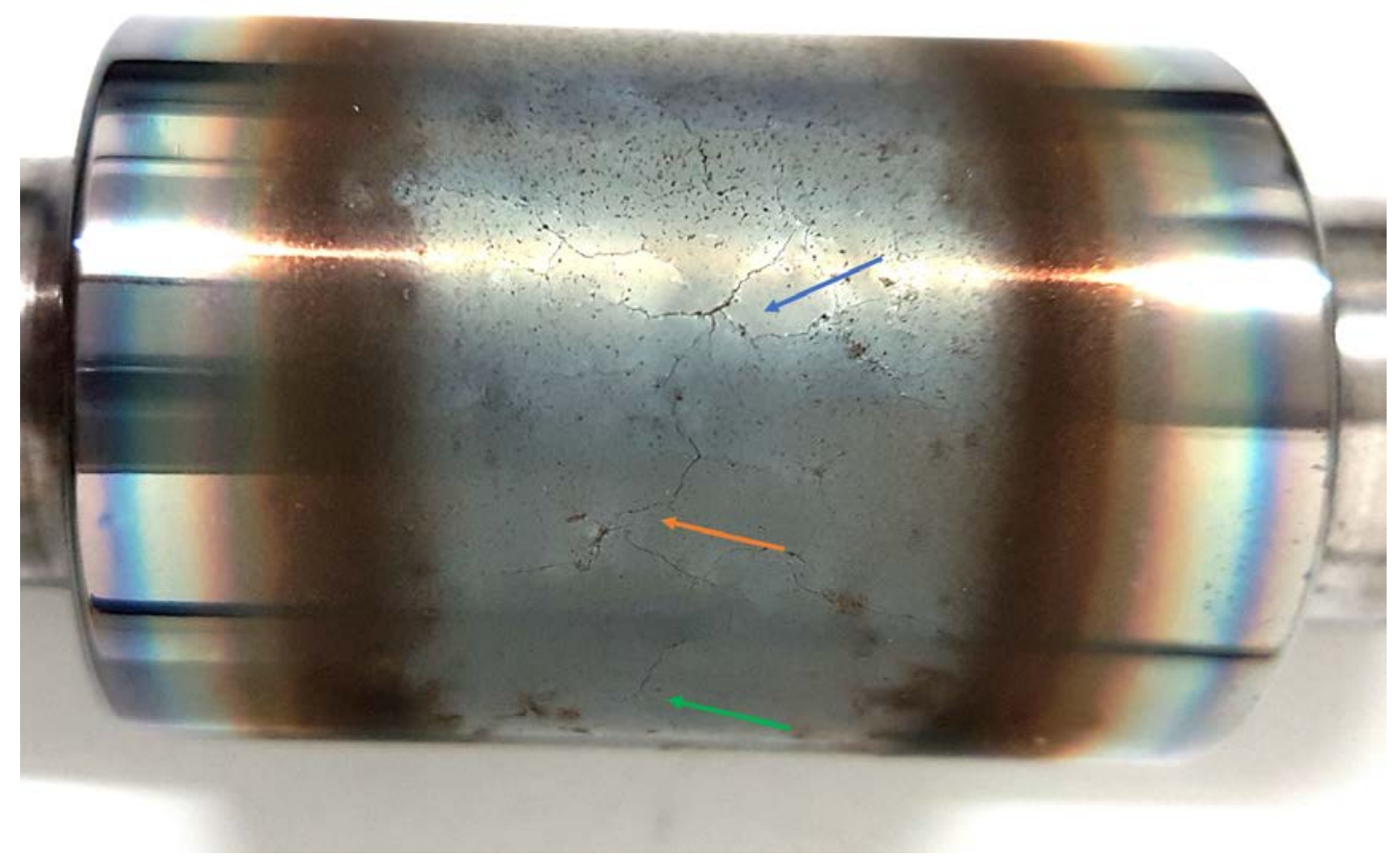

(a)

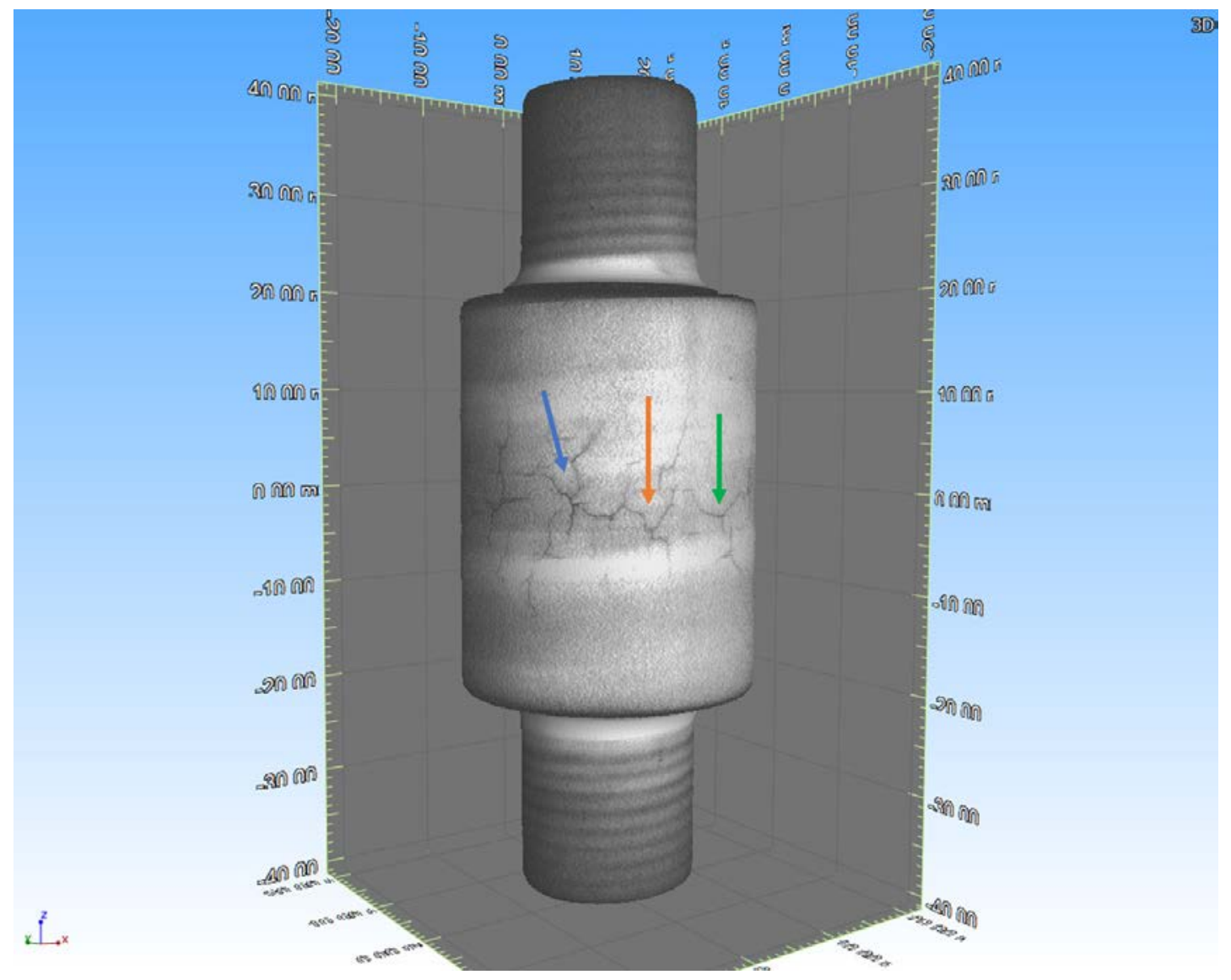

(b)

Figura 4.59: Comparação da amostra REV1 após ensaio e a medição por tomografia de raios-X (a) Fotografia da superfície; (b) Reconstrução 3D. 


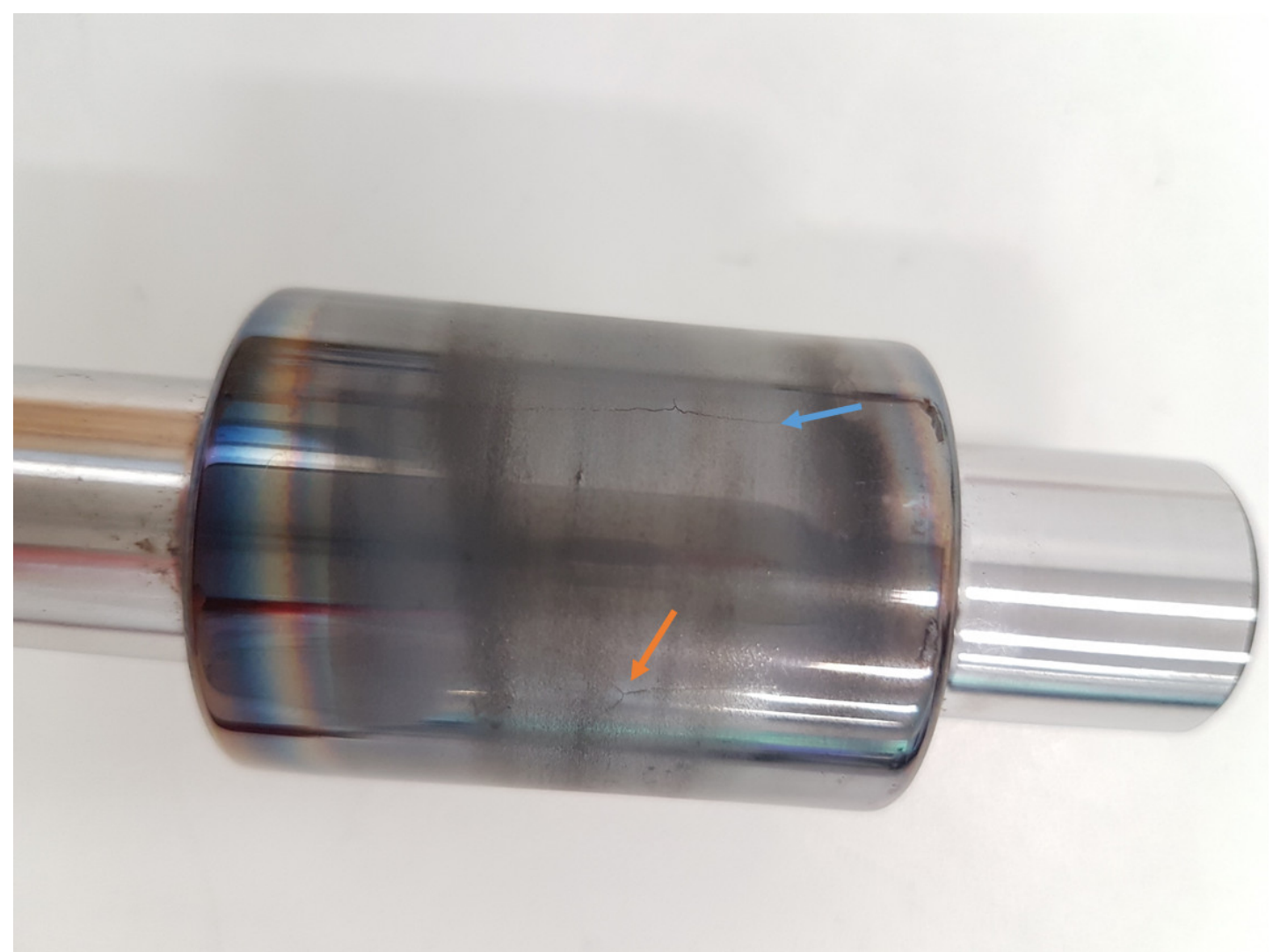

(a)

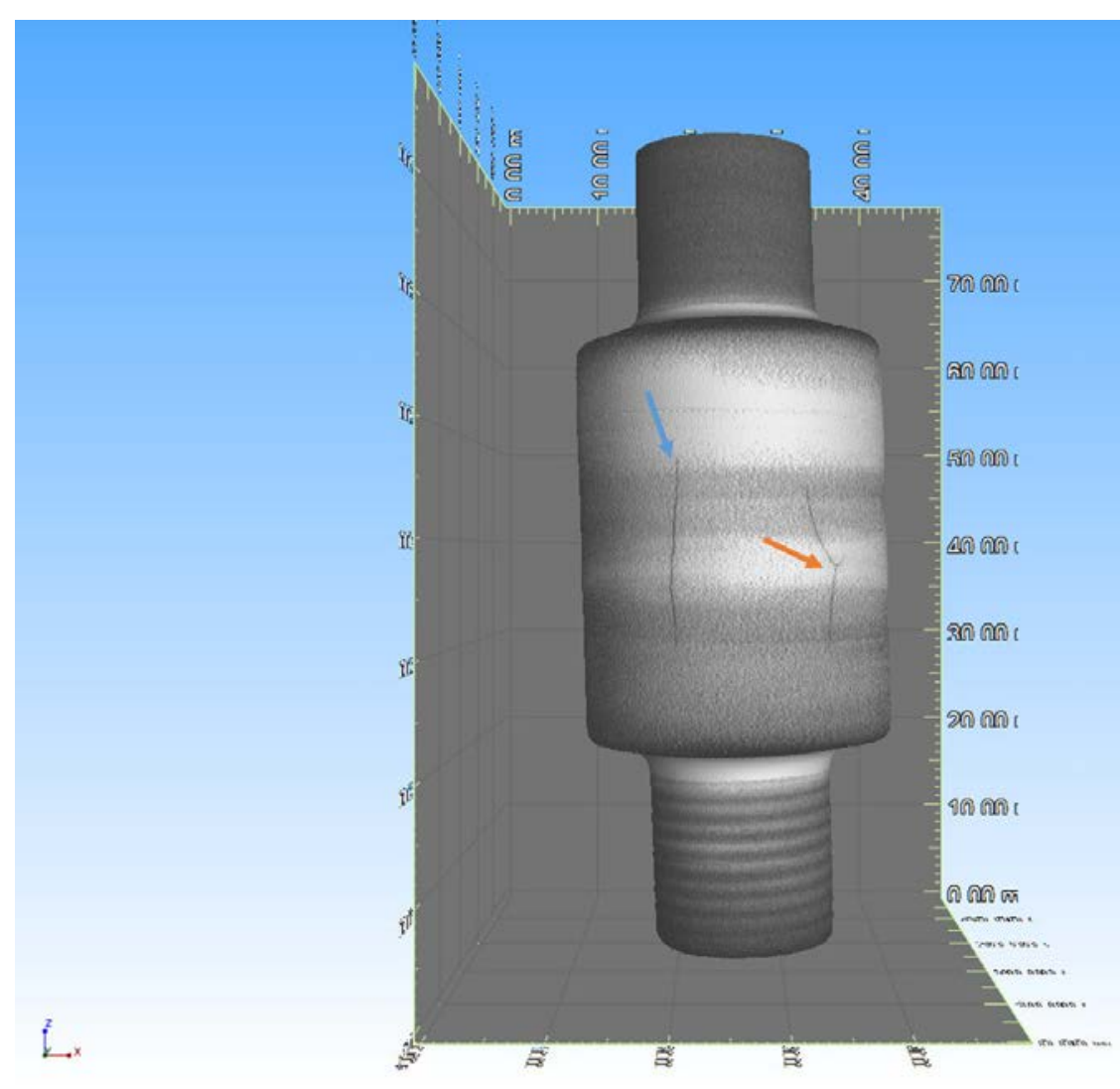

(b)

Figura 4.60: Comparação da amostra ARG1 após ensaio e a medição por tomografia de raios-X (a) Fotografia da superfície; (b) Reconstrução 3D. 
As vistas de topo, lateral direita e rotacional (a partir de um corte vertical no centro) foram exploradas a fim de buscar a melhor forma de identificar as trincas dentro de cada corpo de prova e visualizar o seu caminho de propagação. A seguir, na Figura 4.61, são mostrados exemplos de imagens de tomografia, com marcação das trincas com uma linha vermelha tracejada. $O$ Anexo possui todas as imagens geradas, nas vistas utilizadas nos exemplos, sem os desenhos de linhas vermelhas, que podem interferir na visualização.

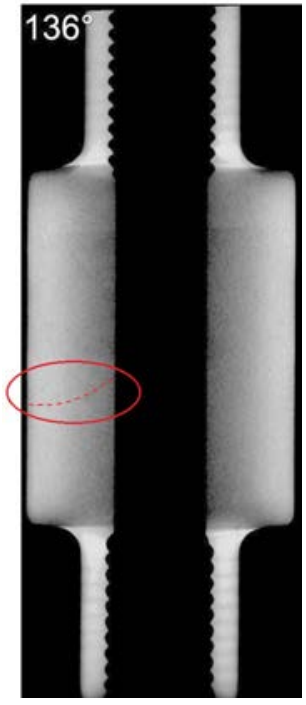

(a)

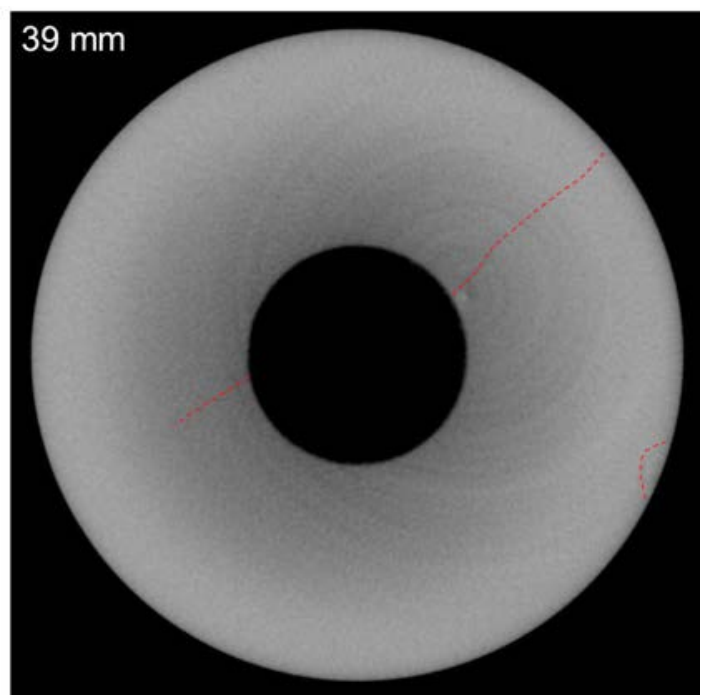

(d)

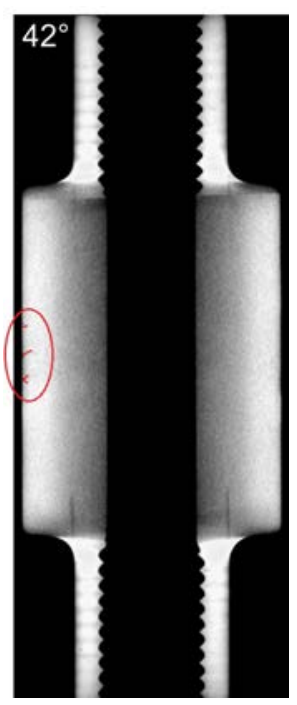

(b) (e)
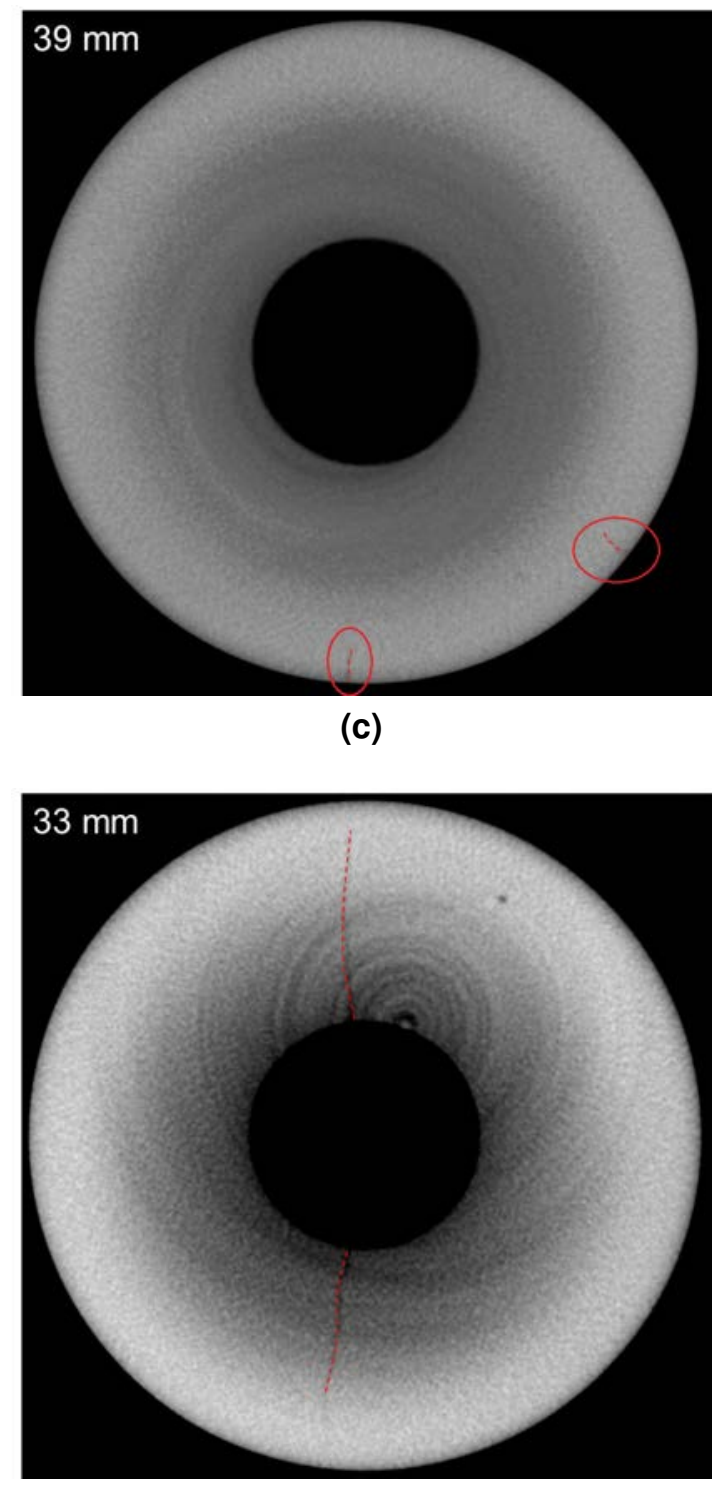

(c)

Figura 4.61: Imagens de trincas feitas por tomografia de raios-X. As trincas foram marcadas com linhas vermelhas tracejadas, para facilitar a visualização. (a) REF2, vista rotacional; (b) REV1, vista rotacional; (c) ARG1, vista topo; (d) HOT2, vista topo; (e) LOW2, vista topo. 
5 Discussão 

No Plano de Trabalho (pág. 75), foi apresentada uma hipótese que seria averiguada através dos experimentos propostos. Propôs-se que a oxidação(1) favorece a fragilização da superfície em condições não homogêneas na microestrutura(2) que, submetida a um carregamento cíclico causado pelo gradiente de temperaturas, sofre fratura proporcional às tensões características do carregamento(3) e propriedades mecânicas do material(4).

Os 4 pontos destacados na sentença acima serão atacados separadamente a seguir:

\subsection{Oxidação}

Os efeitos da interação metal/atmosfera foram investigados no ensaio de oxidação estática e nos ensaios de fadiga térmica. Nos ensaios de oxidação estática foram variados a temperatura e o tempo de exposição à atmosfera. Entre os ensaios de fadiga térmica, as condições de oxidação foram alteradas com a variação da temperatura máxima (condição HOT), do tempo de exposição a altas temperaturas (condição LOW) e do uso de gás inerte (condição ARG). Neste aspecto, as condições REF e REV são similares. De fato, quanto à densidade de trincas secundárias e o aspecto dos Vs, as duas condições foram idênticas.

Quando comparadas a forma e composição química da camada oxidada (Figura 5.1), conclui-se que a espessura de óxido após ensaio cíclico até $600^{\circ} \mathrm{C}$ na condição REF após 4000 ciclos é equivalente àquela formada após a oxidação estática por 240 minutos.

Como a oxidação na condição cíclica é mais difícil de ser analisada, devido às variações de temperatura, pode-se considerar como "tempo de exposição" o que foi mencionado na Seção 4.1, pág. 110, ou seja, o tempo de ciclo em que a superfície está acima de $400^{\circ} \mathrm{C}$.

De acordo com a Tabela 4.2, pág. 154, na condição REF, após 4000 ciclos, a superfície esteve exposta a temperaturas maiores de $400^{\circ} \mathrm{C}$ durante 5240 segundos, ou 87 minutos, pouco mais que um terço do tempo da condição de espessura equivalente, oxidada por 240 minutos. Isso pode ser indício de que a oxidação cíclica é mais severa que a oxidação estática, nessas condições de ensaio. 


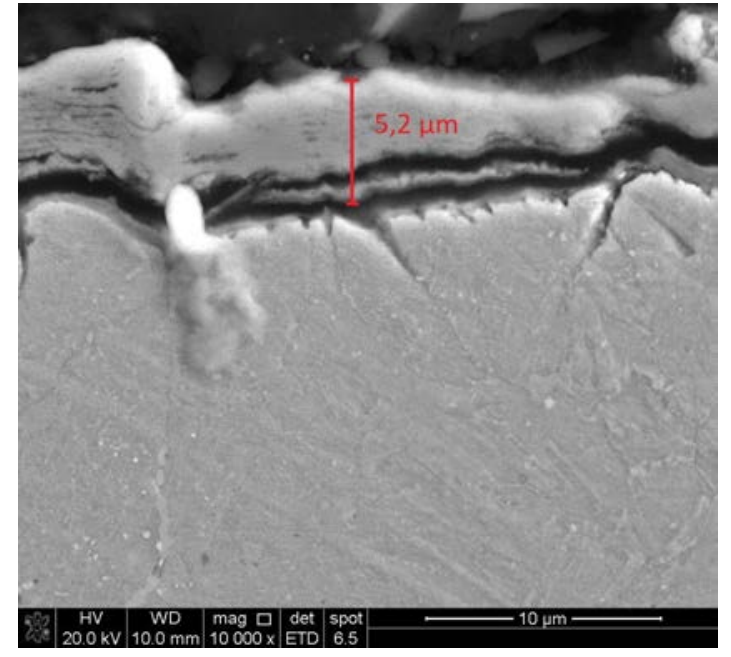

(a)

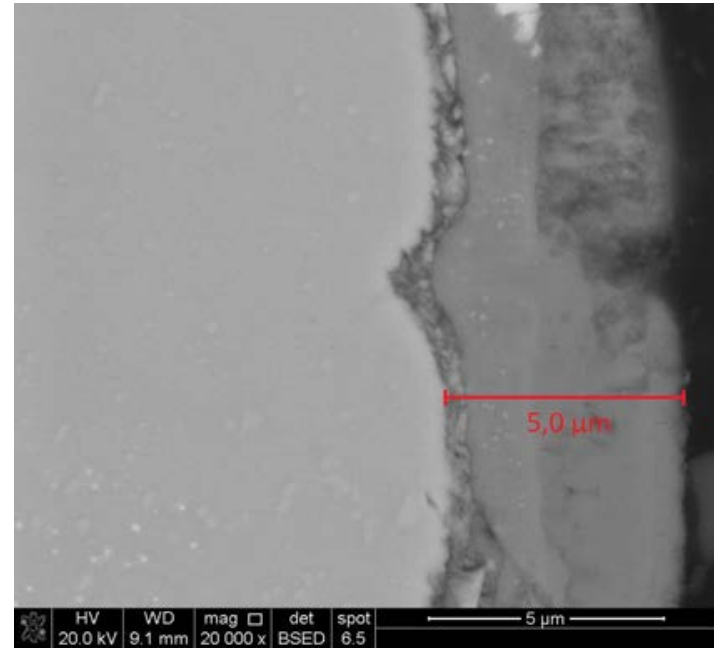

(b)

Figura 5.1: Medição de espessura da camada oxidada. (a) Ensaio de oxidação estática, $600^{\circ} \mathrm{C}, 240$ minutos; (b) Ensaio de fadiga térmica, condição REF, até $600^{\circ} \mathrm{C}, 4000$ ciclos.

Nos estudos de Monteiro ${ }^{[75]}$, variando a composição da atmosfera em termos de misturas de $\mathrm{N}_{2}, \mathrm{O}_{2}$ e $\mathrm{H}_{2} \mathrm{O}$ em ensaios termogravimétricos, o ganho de massa nos ensaios cíclicos foi menor, em comparação aos outros ensaios. Ele supôs que a causa tenha sido desprendimento da camada de óxido. Barrett e Lowell $^{[76]}$ fizeram testes de oxidação por 100 horas contínuas ou em 100 ciclos de 1 hora em 25 materiais ligas comerciais. O dano cíclico é igual, maior ou muito maior que o dano no ensaio estático, dependendo do teor de cromo e da complexidade da liga.

Outros autores, como Mevrel ${ }^{[77]}$, já estudaram o efeito do aquecimento cíclico sobre a formação e quebra da camada de óxido de diferentes ligas metálicas. A forma mais recomendada para esse estudo é a balança termogravimétrica, que dá resultados precisos de variação de massa das amostras. Deste modo, os resultados que puderam ser vistos nos ensaios de fadiga térmica deste trabalho são apenas indicativos de um comportamento que deve ser comprovado em ensaios específicos.

Quanto às variações de condições de oxidação, já foi mostrado anteriormente na Seção 4.3.3, na Figura 4.49, que há aumento do número e profundidade dos Vs em contornos de grão e interfaces matriz/carboneto nas condições HOT e LOW, em comparação à referência, comprovando que em todas as condições de ensaio há efeitos importantes da oxidação sobre a superfície que devem ser considerados. Não foi possível, entretanto, com os recursos disponíveis, determinar por que as trincas secundárias e, consequentemente, 
os Vs, ocorrem preferencialmente em contornos de grão. Entretanto, há indícios na literatura ${ }^{[78,79]}$ de que a orientação dos grãos de óxido têm dependência da direção dos grãos da matriz metálica. Durante a deformação do metal causada pelo ciclo térmico, as regiões de contornos podem ser pontos frágeis da camada de óxido para formação de trincas. Essa hipótese precisa ser comprovada.

O mecanismo de interação entre as trincas primárias e a oxidação já foi estudado por Gell ${ }^{[73]}$, Neu ${ }^{[80,81]}$ e outros autores, visto que é a forma mais comum de visualização de trincas quando se observam apenas amostras com trincas primárias em seção transversal. Um questionamento recorrente é na ordem dos eventos trincamento e oxidação: o material trinca e oxida ou oxida e depois trinca? Além disso, como evolui a oxidação no interior da trinca? Gell ${ }^{[73]}$ explicou o mecanismo de propagação de trinca (estágio $\|{ }^{1}$ ) sob vácuo e ao ar, com oxidação da ponta da trinca (Figura 5.2).

(a)

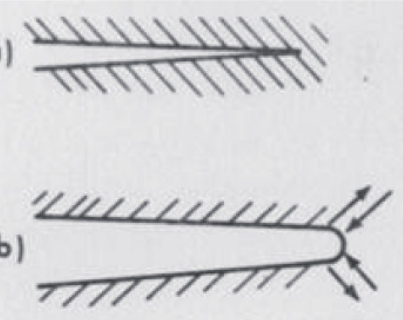

(c)

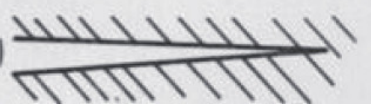

(d)

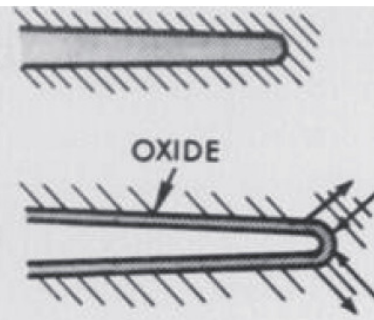

(f)

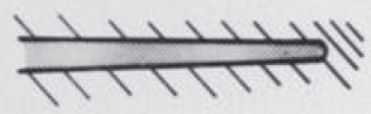

Figura 5.2: Desenho esquemático das formas de propagação de trincas no estágio II sob vácuo $(a, b, c)$ e ao ar (d, e, f), propostas por Gell ${ }^{[73]}$. Em alta temperatura e ao ar, há oxidação das paredes da trinca, reduzindo a capacidade de fechameto da trinca durante a fase de carregamento compressivo. Por outro lado, a ponta da trinca arredondada gera menor concentração de tensões durante a fase trativa do ciclo.

Segundo Gell, quando a temperatura é alta e favorece a oxidação rápida, formam-se óxidos nas superfícies de trincas conectadas à superfície da amostra, reduzindo a capacidade de fechamento da trinca durante a fase de carregamento compressivo do ciclo térmico. Segundo seus estudos, as trincas formadas em ensaios cíclicos sob vácuo são mais finas e nítidas, o que causa também uma taxa de crescimento de trincas maior sob vácuo, uma vez que a ponta da trinca oxidada é mais arredondada e causa menor concentração de tensões na ponta da trinca.

\footnotetext{
${ }^{1} \mathrm{Em}$ mecânica da fratura, divide-se a falha por fadiga em 3 estágio: chama-se de estágio I a nucleação da trinca, estágio II é a propagação e estágio III é a falha catastrófica.
} 
Reavaliando as Figuras 4.23, pág. 128, e 4.25, pág. 130, vêem-se os 3 estágios de formação das trincas: formação dos $\mathbf{V s}$, aprofundamento da oxidação e trincamento do óxido, respondendo à pergunta anterior sobre a ordem dos eventos.

\subsection{Pontos de nucleação de trincas: Condições de hetero- geneidade}

Uma vez determinado que as trincas se iniciam em um ponto de oxidação que avança sobre a microestrutura, deve-se procurar quais são os aspectos da microestrutura que favorecem a ocorrência de oxidação.

A seguir, listam-se algumas particularidades da formação de óxido sobre o aço C99 observada nos ensaios, que também podem ser atribuídas a outros aços:

1. A espessura do óxido não é uniforme;

2. A superfície externa de contato do óxido com a atmosfera é lisa, exceto nos contornos de trincas secundárias (Figura 4.21). Nas bordas das trincas secundárias, o óxido é mais espesso, reforçando a estrutura de trincas em alto relevo;

3. A interface entre o óxido rico em cromo e o óxido pobre em cromo é plana, coincidente com a geometria original do corpo de prova;

4. A interface metal/óxido é rugosa, com pontos em que a oxidação avança em maior velocidade que em outros, que são vistos em seção transversal na forma de Vs;

5. Os pontos de maior velocidade de avanço da oxidação são as interfaces carboneto/matriz. Em segundo lugar, há preferência pelos contornos de grão;

6. Os carbonetos oxidam por último, mesmo aqueles aprisionados na camada de óxido;

7. Os pontos de avanço da oxidação do primeiro para o segundo estágio são sempre contornos de grão. Nos casos em que houve a formação de $\mathbf{V}$ ao redor de um carboneto, a oxidação também avança sobre os contornos de grão vizinhos ao carboneto. 
Os contornos de grão são regiões de oxidação preferencial devido à desordenação atômica localizada entre grãos de orientação cristalina diferentes, fornecendo sítios para difusão de átomos de oxigênio ${ }^{[82]}$. Entretanto, a influência da presença de carbonetos de nióbio na matriz é maior que a dos contornos de grão, como pode ser visto no início da formação da malha de trincas secundárias mostrado na Figura 4.32 (pág. 139). Os pontos onde a oxidação avança perpendicular à superfície trincam na dependência dos estado de tensões. No caso de um alívio de tensões causado, por exemplo, por uma trinca na região vizinha, altera-se a forma da malha de trincas ou o óxido permanece íntegro.

Sugere-se, como tema para estudos futuros, a investigação da influência do tamanho e orientação dos grãos sobre a formação das malhas primária e secundária de trincas.

\subsection{Relações entre trincas e o carregamento}

Tradicionalmente, calcula-se a tensão gerada pelo ciclo térmico pelas equações Equação (2.5) $\left(\sigma=\frac{E \alpha \Delta T}{1-\nu}\right)$ ou Equação (2.6) $\left(\sigma=\frac{E \cdot \Delta \alpha \cdot \Delta T}{1-\nu}\right)$, em caso de filmes finos.

Entretanto, entende-se que há 3 diferentes $\Delta T$ 's, que serão detalhados a seguir.

\subsection{1 $\Delta T_{C}$}

$\Delta T_{C}$ é a diferença entre a temperatura da superfície e a temperatura mínima do ciclo térmico aplicado sobre a superfície e varia com o tempo entre 0 e $T_{\max }-T_{\min }$ :

$$
\begin{aligned}
& \Delta T_{C}=T_{\text {sup }}(t)-T_{\min } \\
& \Delta T_{C}: t \rightarrow\left[0,\left(T_{\max }-T_{\text {min }}\right)\right]
\end{aligned}
$$

onde $t$ é o tempo de ciclo;

$T_{\text {sup }}(t)$ é a temperatura da superfície metálica no instante t;

$T_{\min }$ é a temperatura mínima de setup do ciclo térmico; e

$T_{\max }$ é a temperatura máxima de setup do ciclo térmico. 
enciam na oxidação, na variação de propriedades do metal e na dilatação térmica.

\subsection{2 $\Delta T_{o}$}

$\Delta T_{o}$ é a diferença entre a temperatura da superfície metálica e a temperatura da camada de óxido, considerando que a espessura da camada é fina o suficiente para ser considerada homogênea a temperatura dentro do óxido:

$$
\begin{aligned}
& \Delta T_{o}=T_{\text {sup }}(t)-T_{o}(t) \\
& \Delta T_{o}: t \rightarrow\left[0,\left(T_{\max }-T_{a m b}\right)\right]
\end{aligned}
$$

onde $T_{o}(t)$ é a temperatura do óxido no instante t; e $T_{a m b}$ é a temperatura ambiente.

Há 3 características que influenciam na origem e magnitude do $\Delta T_{o}$ : o fato de que o aquecimento indutivo aquece apenas o metal, fazendo com que a camada de óxido aqueça por condução a partir do metal; as baixas condutividade e condutância térmica do óxido, que retardam o seu aquecimento em relação ao metal; e a perda de calor para a atmosfera por radiação. Existe uma possibilidade que pode ser verificada em trabalhos futuros de que a temperatura medida pelo pirômetro óptico ao longo do ensaio não reflita a real temperatura do metal, devido à diferença de temperatura entre metal e óxido. Para efeitos práticos, esse efeito será relevado neste trabalho.

Independente de $\Delta T_{o}$ ser igual ou maior que zero, camadas de óxido têm geralmente coeficientes de expansão térmica mais baixos do que os substratos metálicos nos quais elas crescem. Durante uma variação de temperatura, esta diferença de dilatação induz tensões térmicas que, adicionadas às tensões de crescimento, podem causar a fissuração e eventual destacamento do óxido ${ }^{[77]}$. Esta é a fonte das trincas secundárias de fadiga térmica. As trincas dentro da camada de óxido fornecem um "curto-circuito" para espécies oxidantes. Em áreas do metal expostas à atmosfera (trincas secundárias), uma superfície metálica empobrecida em cromo fica em contato direto com o meio ambiente, acelerando o dano. Tanto o trincamento como o eventual desplacamento levam a uma oxidação acelerada. No aço C99, os carbonetos evitam o desplacamento da camada de óxido sobre a matriz, como mostrou a Figura 4.6. É esse o mecanismo que explica a formação dos Vs na interface metal/óxido, que são os pontos que antecedem a formação de uma trinca 
primária.

Quando a velocidade de aquecimento/resfriamento é lenta o bastante para permitir que a transmissão de calor entre metal e óxido iguale as duas temperaturas durante a mudança de temperatura, as tensões entre metal e óxido são mínimas, embora não sejam nulas. No entanto, se as mudanças de temperatura são bruscas, somam-se às tensões térmicas causadas pela dilatação outras tensões causadas pela diferença de temperatura entre óxido e substrato. É este gradiente de temperaturas o responsável pela formação de diferentes densidades de trincas na malha de trincas secundárias quando varia a velocidade de aquecimento entre as condições REF e LOW, por exemplo. Ou seja, quanto mais lento (rápido) o aquecimento, menor (maior) deve ser a densidade de trincas secundárias na superfície. É direta, portanto, a relação entre o número de trincas secundárias e o número de pontos de concentração de tensões durante o carregamento térmico.

\subsection{3 $\Delta T_{x}$}

$\Delta T_{x}$ é a diferença entre a temperatura da superfície e a temperatura em outro ponto da amostra à distância $x$ da superfície:

$$
\begin{aligned}
& \Delta T_{x}=T_{\text {sup }}(t)-T_{x}(h, t) \\
& \Delta T_{x}: t, h \rightarrow\left[0,\left(T_{\max }-T_{\text {agua }}\right)\right] \\
& h \in[0, H] \\
& \quad \text { onde } T_{x}(h, t) \text { é a temperatura do metal à profundidade } h, \text { no instante } t ; \\
& \\
& T_{\text {agua }} \text { é a temperatura da água que passa pelo corpo de prova; e } \\
& \\
& H \text { é a espessura do corpo de prova. }
\end{aligned}
$$

Note que, segundo esse raciocínio, existem também um $\Delta T_{y}$ e um $\Delta T_{z}$ em um sistema de coordenadas $(x, y, z)$ fixado no corpo de prova.

O aquecimento indutivo de alta frequência aquece uma camada muito fina da superfície externa de dezenas de micrômetros. O restante do material, como foi visto na Seção 4.2, aquece por condução de forma dependente da temperatura e da velocidade de aquecimento da superfície, gerando um perfil de temperaturas e, consequentemente, de tensões característico do ciclo térmico imposto.

A origem das tensões é a restrição à movimentação de material para dila- 
tar ou contrair durante, respectivamente, as etapas de aquecimento ou resfriamento, conforme mecanismo já descrito na Seção 2.4.2 e calculado na Seção 4.2. A restrição sofrida por uma região, causada pela região logo abaixo dela (mais fria) é proporcional ao $\Delta T_{x}$. Ou seja, quanto maior a diferença de temperaturas entre as duas regiões, maior será a tensão aplicada sobre a região carregada (a equação tradicional do cálculo de tensões térmicas).

Agravam as tensões térmicas os concentradores de tensões na microestrutura, como os carbonetos, irregularidades da superfície e pontos de oxidação preferencial.

\subsection{Propriedades mecânicas}

Além dos fatores já apresentados, deve-se manter em mente que o perfil de temperaturas está associado a um perfil de propriedades, como exemplificado na Figura 5.3, que mostra esquematicamente a direção de variação das propriedades em um material aquecido em apenas um dos lados, com o outro lado mantido mais frio.

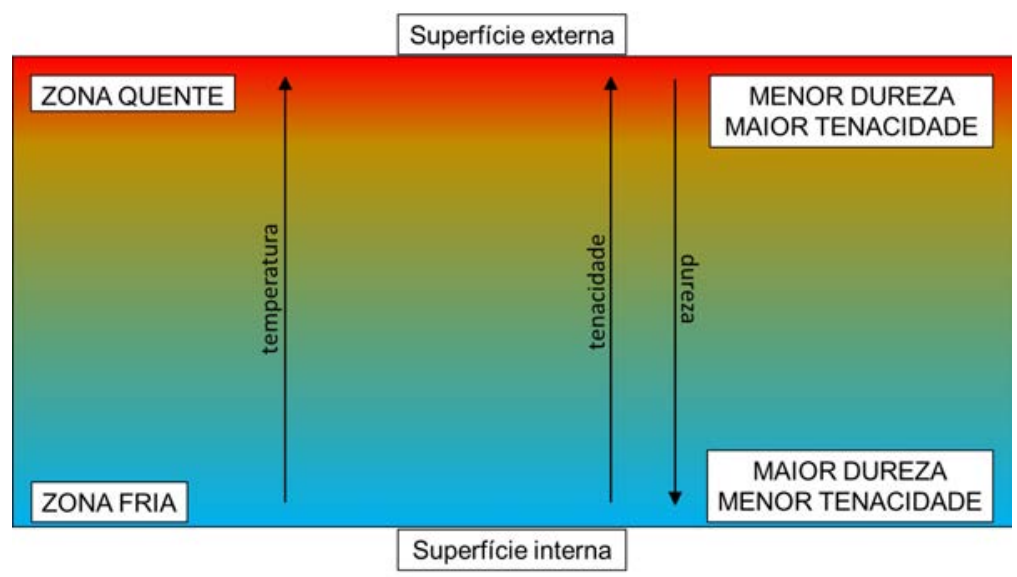

Figura 5.3: Exemplo de um material com gradiente de temperaturas e propriedades mecânicas (dureza e tenacidade). O decréscimo da dureza está associado ao aumento da tenacidade.

A tensão limite de escoamento (relacionada à dureza) e tenacidade à fratura são as duas principais propriedades mecânicas de interesse na proteção contra nucleação e propagação de trincas de fadiga térmica. Gurcan ${ }^{[26]}$ descreveu o comportamento de aços ferramentas em fadiga térmica como influenciado, entre outras coisas, por dois efeitos opostos. A nucleação da trinca começa sob carregamento cíclico quando o limite de resistência é excedido localmente. As primeiras trincas aparecem, p.e. em inclusões não metálicas ou carbonetos eutéticos. Esse efeito pode ser retardado por uma alta dureza, 
mas isso é limitado pela perda de tenacidade e o risco de quebra. Segundo Roberts, Krauss e Kennedy ${ }^{[29]}$, boa tenacidade e resistência à fratura são requeridas para situações como sobrecargas ou cargas na presença de entalhes ou cantos agudos, onde a tensão aplicada excede os limites elásticos.

Uma vez iniciada uma trinca, é benéfico para a ferramenta exibir uma boa resistência à propagação de trincas. Como a fadiga térmica é inevitável, o maior benefício é retardar a propagação das trincas com uma boa combinação de estabilidade em alta temperatura e tenacidade. Nesse contexto, consideram-se materiais com boa resistência à fadiga térmica os que desenvolvem trincas menores. ${ }^{[26]}$

\subsection{Resumo das condições de ensaio}

Nos ensaios de fadiga térmica realizados, foram observadas formações diferentes de trincas térmicas secundárias e primárias para cada condição de ensaio (Tabela 5.1), analisadas caso a caso nas sessões seguintes:

Tabela 5.1: Quadro resumo das análises de trincas nas condições de ensaio estudadas.

\begin{tabular}{|c|c|c|c|c|c|}
\hline \multirow{3}{*}{$\begin{array}{c}\text { Condição } \\
\text { de } \\
\text { ensaio }\end{array}$} & \multicolumn{4}{|c|}{ Malha de trincas } & \multirow{3}{*}{$\begin{array}{c}\text { Ciclos para } \\
\text { falha } \\
\left(N_{f}\right)\end{array}$} \\
\hline & \multirow{2}{*}{$\begin{array}{c}\text { Secundária } \\
\text { Dens. estável }\end{array}$} & \multicolumn{3}{|c|}{ Primária } & \\
\hline & & Forma da malha & Nucleação & Passante & \\
\hline REF & $95 \pm 9 \mathrm{~mm} / \mathrm{mm}^{2}$ & Linhas longas & Externa & Sim & 3333 \\
\hline НОТ & $85 \pm 6 \mathrm{~mm} / \mathrm{mm}^{2}$ & Linhas curtas & Externa & Sim & 817 \\
\hline LOW & $66 \pm 5 \mathrm{~mm} / \mathrm{mm}^{2}$ & Não tem & Interna & Sim & 4666 \\
\hline REV & $95 \pm 6 \mathrm{~mm} / \mathrm{mm}^{2}$ & Quadriculada & Externa & Não & 3333 \\
\hline ARG & $0 \mathrm{~mm} / \mathrm{mm}^{2}$ & Linhas longas & Externa & Não & $3000+$ \\
\hline
\end{tabular}

\subsubsection{REF}

Nos ensaios de fadiga térmica na condição de referência, foi possível observar os efeitos dos três gradientes de temperatura detalhados anteriormente. A existência de uma camada de óxidos, associada ao $\Delta T_{o}$, gerou uma malha de trincas secundárias e, abaixo dela, pontos de oxidação preferencial que agiram como concentradores de tensão em somatória às tensões extrínsecas devido aos diferentes coeficientes de expansão térmica entre carboneto e matriz. A amplitude do ciclo térmico, $\Delta T_{C}$, afetou as propriedades do material de 
modo a favorecer a oxidação e a deformação plástica do material da superfície. A região deformada plasticamente falhou, submetida ao ciclo de tensões gerados na direção de $\Delta T_{x}$, gerando trincas que se propagaram na direção axial, atravessando toda a espessura dos corpos de prova pelas zonas de menor tenacidade e fazendo vazar água pela superfície.

\subsubsection{HOT}

Comparando-se com a condição REF, pode-se aferir que, na condição HOT, os gradientes de temperaturas $\Delta T_{C}$ e $\Delta T_{x}$ maiores que a referência geraram tensões maiores, que aceleraram a nucleação e propagação de trincas na direção $x$. Não houve tempo para propagação nas outras direções, deixando as trincas com pequeno comprimento quando observadas nas direções paralelas à superfície. Como a velocidade de aquecimento das duas condições é a mesma, $\Delta T_{o}$ é igual nas duas condições, resultando em densidades de trincas secundárias semelhantes.

\subsubsection{LOW}

Como foi visto nos modelos 2D (Figuras 4.15, 4.16 e 4.17, a face interna dos corpos de prova, ao final do aquecimento, pode ser submetida a tensões trativas altas, sendo a mais alta na condição LOW, maior que $700 \mathrm{MPa}$ - na direção de $\Delta T_{x}$. A geração de tensões altas nas zonas frias pode gerar condições de carregamento nocivas em regiões de baixa tenacidade do metal.

Isso explica o fato de que os corpos de prova, quando ensaiados na condição LOW falhavam por vazamento de água na região do pescoço. Uma vez nucleadas na zona fria do material, próximo à parede do furo, as trincas propagavam na direção longitudinal, pelo furo, e na direção radial. O ponto de menor espessura é o pescoço, razão pela qual era o ponto onde as trincas afloravam primeiro.

A menor densidade de trincas secundárias se explica pelo maior tempo de propagação de calor metal/óxido, gerando um $\Delta T_{o}$ menor.

\subsubsection{REV}

Os corpos de prova super-revenidos, com baixa dureza, têm também maior tenacidade. A baixa dureza, como já foi explicado, diminui a resistência à nu- 
cleação de novas trincas, porém a alta tenacidade retarda a sua propagação. Por este motivo, os corpos de prova ensaiados na condição REV têm um número consideravelmente maior de trincas primárias que as demais condições, porém nenhuma trinca atravessou toda a espessura de metal. A formação de uma malha quadriculada favoreceu a conexão de trincas, que ocasionou desprendimento de material e perda de massa, o principal fator de empobrecimento do acabamento de cilindros industriais.

Como as condições de aquecimento e atmosfera geraram o mesmo $\Delta T_{o}$ da condição REF, a malha de trincas térmicas não se alterou.

\subsubsection{ARG}

Os corpos de prova ensaiados em atmosfera com menor potencial oxidante não tiveram formação de camada oxidada e, portanto, de malha de trincas secundárias. A ciclagem térmica causou falha dos corpos de prova por fadiga de baixo ciclo, com nucleação de trincas em outros concentradores de tensão, como os defeitos de fundição. Não foi possível avaliar, sob as mesmas condições, outros corpos de prova sem defeitos de fundição, a fim de verificar se o tempo de vida seria maior. 


\section{Conclusões}



O estudo dos mecanismos de nucleação de trincas de fadiga térmica em um aço ferramenta com carbonetos de nióbio com variação da temperatura máxima, velocidade de aquecimento, dureza e atmosfera mostrou que:

1. É impossível separar os estudos de oxidação e fadiga térmica nas condições normais de operação de ferramentas expostas à atmosfera em altas temperaturas;

2. Há mecanismos diferentes para explicar o surgimento de uma malha de trincas secundária, restrita à camada de óxido, e uma malha primária, que leva o material à falha:

(a) A malha de trincas secundária tem influência na nucleação de trincas primárias pela criação de pontos de concentração de tensão na interface metal/óxido;

(b) A malha secundária, na camada de óxido, forma-se por diferença entre a dilatação térmica da camada de óxido e do substrato durante o ciclo térmico. A densidade de trincas depende da diferença de temperaturas entre os dois materiais $\Delta T_{o}$;

(c) A malha secundária inicia em pontos de oxidação preferencial iniciados na malha secundária que se aprofundam dentro da matriz, gerando filmes frágeis entre os contornos de grão. $O$ crescimento das trincas primárias segue a sequência oxidação $\rightarrow$ trincamento, e não o contrário.

3. Os carbonetos de nióbio têm papel importante na nucleação de trincas secundárias e primárias:

(a) A interface carboneto/matriz oxida antes da matriz;

(b) As primeiras trincas secundárias surgem a partir dos carbonetos;

(c) A oxidação dos contornos de carbonetos soma-se às trincas secundárias como pontos de nucleação de trincas primárias.

4. Todos os parâmetros de ensaio tiveram impacto relevante na evolução do dano de fadiga térmica:

(a) O parâmetro com maior influência no tempo de vida em fadiga térmica foi a temperatura máxima;

(b) A presença de defeitos de fundição pode ter mascarado outros efeitos estudados quanto ao tempo de vida; 
(c) O parâmetro com maior influência na densidade de trincas secundárias é a velocidade de aquecimento;

(d) O aumento da temperatura máxima diminui o tempo de vida, mas não altera a densidade de trincas secundárias;

(e) O aquecimento lento diminui a densidade de trincas secundárias e parece não alterar o tempo de vida;

(f) O aquecimento lento leva à falha por trincas nucleadas na região mais fria do material;

(g) A dureza influenciou no número e profundidade das trincas primárias, mas nao alterou a malha secundária;

(h) O ensaio em atmosfera não oxidante foi afetado pela presença de defeitos de fundição, porém comprovou-se que não há formação de trincas secundárias na ausência de oxidação da superfície. 


\section{Referências}

1 SURESH, S. Fatigue of Materials. 2nd. ed. Cambridge, UK: Cambridge University Press, 1998. 679 p.

2 BRANDIM, A. S.; SOUSA, R. R. M.; ALVES JR., C. Desenvolvimento de um equipamento para ensaio de fadiga térmica. Revista Matéria, v. 14, n. 1, p. 749-758, 2009. Disponível em: $<$ http://www.materia.coppe.ufrj.br/sarra/artigos/artigo11042>.

3 MEDJEDOUB, F. Détermination des paramètres influant sur le phénomène d'endommagement par fatigue thermique des moules en fonderie sous pression d'aluminium. Tese (Doutorado) - Ecole Nationale Supérieure des Mines de Paris, 2004.

4 SPERA, D. A. What is thermal fatigue? In: ASTM INTERNATIONAL. Thermal Fatigue of Materials and Components, ASTM STP 612. New Orleans, EUA, 1976. p. 3-9.

5 SERANTONI, C. R. Fadiga térmica de ferros fundidos brancos multicomponentes. Dissertação (Mestrado) - Escola Politécnica da USP, São Paulo, 2003.

6 SILVA, P. F. Desgaste e fadiga térmica de ligas "aço matriz + NbC". 164 p. Dissertação (Mestrado) - Escola Politécnica da USP, São Paulo, 2006.

7 EBNER, R. et al. Methodology for advanced tool load analysis and lifetime prediction of tools. In: ASMET. Proceedings of the 9th international tooling conference. Leoben, Áustria, 2012. p. 3-21.

8 BOCCALINI JR, M.; FARINA, P. F. da S. Thermal fatigue of Nb-bearing alloys for hot rolling mill rolls. In: Proceedings of the 9th International ToolingConference. Leoben, Áustria: [s.n.], 2012. p. 375-382.

9 PERSSON, A.; BERGSTRöM, J.; BURMAN, C. Evaluation of heat checking damage in die casting. In: Proceedings of the 5th International Tooling Conference. Leoben, Austria: [s.n.], 1999. p. 167-177.

10 JEAN, S. et al. An investigation on heat checking of hot work tool steels. In: Proceedings of the 5th International Tooling Conference. Leoben, Austria: [s.n.], 1999. p. 185-193.

11 MIN, Y.; XU, L.; WU, X. Influence of surface heat treatment on thermal fatigue behaviors of hot work steels. In: Proceedings of the 6th International Tooling Conference. Karlstad, Sweden: [s.n.], 2002. v. 1, p. 55-63.

12 PIROVANO, M. Thermal fatigue in new lower hardening temperature hot work steels. In: Proceedings of the 6th International Tooling Conference. Karlstad, Sweden: [s.n.], 2002. v. 1, p. 469-477. 
13 PENG, W. et al. Comparison of thermal fatigue behavir of plasma nitriding with compound layer and without it of h13 steel. In: Proceedings of the 6th International Tooling Conference. Karlstad, Sweden: [s.n.], 2002. v. 1, p. 497-506.

14 VELAY, V. et al. Thermal fatigue of a tool steel: Experiment and numerical simulation. In: Proceedings of the 6th International Tooling Conference. Karlstad, Sweden: [s.n.], 2002. v. 2, p. 667-685.

15 SRIVASTAVA, A.; JOSHI, V.; SHIVPURI, R. Numerical models and their validity in the prediction of heat checking in die casting tooling. In: Proceedings of the 6th International Tooling Conference. Karlstad, Sweden: [s.n.], 2002. v. 2, p. 643-655.

$16 \mathrm{WU}, \mathrm{X}$; $\mathrm{XU}$, L. Computer aided evaluation of thermal fatigue cracks on hot work tool steel. In: Proceedings of the 6th International Tooling Conference. Karlstad, Sweden: [s.n.], 2002. v. 2, p. 657-666.

17 EBNER, R. et al. Thermal fatigue behaviour of hot work tool steels - heat check nucleation and growth. In: Proceedings of the 7th International Tooling Conference. Torino, Italy: [s.n.], 2006. v. 1, p. 161-173.

18 MEDJEDOUB, F. et al. Experimental conditions and environment effects on thermal fatigue damage accumulation and life of die-casting steel x38crmov5 (aisi h11). In: Proceedings of the 7th International Tooling Conference. Torino, Italy: [s.n.], 2006. v. 2, p. 461-469.

19 KLOBCAR, D. et al. Influence of thermal fatigue on materials for diecasting tooling. In: Proceedings of the 7th International Tooling Conference. Torino, Italy: [s.n.], 2006. v. 2, p. 479-486.

20 ZEESHAM, A. et al. Cyclic behaviour simulation of x398crmov5-47hrc (aisi h11) tempered martensitic hot work tool steel. In: Proceedings of the 7th International Tooling Conference. Torino, Italy: [s.n.], 2006. v. 2, p. 513-520.

21 WANG, H.; WU, X.; XU, L. Thermal fatigue behavior of h13 steel with nanocrystalline surface induced by surface mechanical atrition. In: Proceedings of the 7th International Tooling Conference. Torino, Italy: [s.n.], 2006. v. 2, p. 521-528.

22 PELLIZARI, M. et al. Thermal fatigue properties of hot work tool steels. In: Proceedings of the 7th International Tooling Conference. Torino, Italy: [s.n.], 2006. v. 2, p. 529-536.

23 DOUR, G. et al. Size effect in transient thermal fatigue testing and thermo-mechanical screening of coatings. In: Proceedings of the 7th International Tooling Conference. Torino, Italy: [s.n.], 2006. v. 2, p. 555-562.

24 LE ROUX, S. et al. Application of image analysis for thermal fatigue heat checking investigations. In: Proceedings of the 8th International Tooling Conference. Aachen, Germany: [s.n.], 2009. v. 2, p. 687-696.

25 DEIRMINA, F.; PELLIZARI, M. Thermal fatigue resitance of a pm tool steel with bimodal grain size. In: ASMET. Proceedings of the 10th international tooling conference. Bratislava, Eslováquia, 2016. p. 121-129. 
26 GÜRCAN, M.; SCHNEIDERS, T.; BEUTLER, U. New hot work tool steel thermodur E $40 \mathrm{~K}$ superclean. In: ASMET. Proceedings of the 10th international tooling conference. Bratislava, Eslováquia, 2016. p. 226-235.

27 TERC̆ELJ, M.; KUGLER, G. Thermal fatigue testing of hot working tool steels. In: ASMET. Proceedings of the 10th international tooling conference. Bratislava, Eslováquia, 2016. p. 265-272.

28 LE ROUX, S.; RÉZAÏ-ARIA, F. Applications of image analyses to heat-checking characterisations under thermal fatigue solicitations of high temperature tool steels. In: ASMET. Proceedings of the 10th international tooling conference. Bratislava, Eslováquia, 2016. p. 302-313.

29 ROBERTS, G.; KRAUSS, G.; KENNEDY, R. Tool steels. 5. ed. Materials Park, OH, EUA: ASM International, 1998. 364 p.

30 BOCCALINI JR., M.; SOUZA, R. M. de. Sistema avançado para projeto de ligas aplicadas em ferramentas de conformação a quente. São Paulo, 2017. Acesso restrito.

31 YANG, Y. et al. Comparison of thermal properties of laser deposition and traditional welding process via thermal diffusivity measurement. In: UNIVERSITY OF TEXAS PRESS. Solid Freeform Fabrication Proceedings. [S.I.], 2006. p. 446-452.

32 PIERSON, H. O. Handbook of Refractory Carbides and Nitrides: Properties, characteristics, processing and applications. New Jersey: Noyes Publication, 1997. $362 \mathrm{p}$.

33 ANDREIS, G.; FUCHS, K. D.; SCHRUFF, I. The wear behaviour of hot-work tool steels used in forging processes. In: 5th International Tooling Conference. Leoben, Áustria: [s.n.], 1999. p. 593-600.

34 GONÇALVES, C. S. Efeito do processo de nitretação sob plasma no comportamento em fadiga térmica dos aços ferramenta para moldes para injeção de alumínio sob pressão. 175 p. Dissertação (Mestrado) - Escola Politécnica da USP, São Paulo, 2012.

35 STAHLBERG, U.; HALLSTROM, J. A comparison between two wear models. Journal of Materials Processing Technology, v. 87, p. 223-229, 1999.

36 BIGLARI, F. R.; ZAMAMI, M. Die wear profile investigation in hot forging. In: Proceedings of the World Congress on Engineering. Londres, RU: [s.n.], 2008. II.

37 KOHOPÄÄ, J.; HAKONEN, H.; KIVIVUORI, S. Wear resistance of hot forging tools surfaced by welding. Wear, n. 130, p. 103-112, 1989.

38 GARZA-MONTES-DE-OCA, N. F.; RAINFORTH, W. M. Wear mechanisms experienced by a work roll grade high speed steel under different environmental conditions. Wear, v. 267, p. 441-448, 2009.

39 LIMA, L. G. D. B. da S. et al. Coupled experimental-numerical analysis of wear in hot rolling rolls. In: ASMET. Proceedings of the 10th international tooling conference. Bratislava, Eslováquia, 2016. 
40 SCHRUFF, I.; GüMPEL, P. Corrosion - an often neglected phenomenon in hot-work tools. In: ASMET. Proceedings of the 10th International Tooling Conference. Bratislava, Eslováquia, 2016. p. 102-111.

41 WERONSKI, A.; HEJWOWSKI, T. Thermal fatigue of metals. Nova lorque, EUA: Marcel Dekker, 1991. 366 p.

42 ABRAHÃO, R. R. R. et al. Fadiga de materiais - uma revisão bibliográfica. In: Anais do VIII Encontro Interno e XII Seminário de Iniciação Científica. Uberlândia, MG: [s.n.], 2008. p. 10.

43 MANN, J. Y. Fatigue of materials: An introdutory text. Austrália: Melbourne University Press, 1967. $155 \mathrm{p}$.

44 MOIA, D. de G. Previsão da vida em fadiga de materiais metálicos. Parte l: Estudo preliminar da vida em fadiga do aço ABNT1016 recozido. São Bernardo do Campo, 2001.

45 DAVIDSON, D. L.; LANKFORD, J. Fatigue crack growth in metals and alloys: mechanisms and micromechanics. International Materials Reviews, v. 37, n. 2, p. 45-76, 1992.

46 ZUCHOWSKI, R. Analysis of the thermal fatigue process. Journal of Materials Processing Technology, v. 106, n. 1, p. 167-172, 2000.

47 MATSUMOTO, M. M. Estudo sobre a resistência à ciclagem térmica dos ferros fundidos de alto cromo e do aço ferramenta AISI D2. Dissertação (Mestrado) - Escola Politécnica da USP, São Paulo, 2011.

48 HOWES, M. A. H. Fatigue at elevated temperatures. In: London: American Society for Testing and Materials, 1973. cap. Evaluation of thermal fatigue resistance of metals using the fluidized bed technique, p. 242-254.

49 RÉZAï-ARIA, F. et al. Some aspects of thermal fatigue of metallic tools. In: Abrasion Conference. [S.I.: s.n.], 2005.

50 REBOLLO, D. Transferencia de calor y materia. 2014. Acesso em ago. 2017. Disponível em: <https://sites.google.com/site/tcmdefiunsj/ tema-2>.

51 MANSON, S. S. Thermal stress and low-cycle fatigue. In: . New York: McGraw-Hill, 1966. cap. Thermal Shock, p. 275-312.

52 HERTZBERG, R. W. Deformation and fracture mechanics of engineering materials. 4. ed. New York: John Wiley, 1995. 786 p.

53 MALM, S.; NORSTRÖN, L. A. Material-related model for thermal fatigue applied to tool steels in hot-work applications. Metal Science, v. 13, n. 9, p. 544-550, set 1979 .

54 PARK, J. $\mathrm{H}$. The effects of alloying elements on thermal fatigue and thermal shock resistance of the hsla cast steels. ISIJ Journal, v. 40, n. 11, p. 1164-1169, 2000.

55 CARDEN, A. E. Thermal fatigue - an analysis of the experimental method. Oak Ridge, EUA, 1963. 
56 HASSELMAN, D. P. H.; SINGH, J. P. Thermal stresses i. In: New York: North-Holland, 1986. cap. Criteria for the Thermal Stress Failure of Brittle Structural Ceramics, p. 263-298.

57 TANG, W. et al. Effect of microstructural homogeneity on mechanical and thermal fatigue. In: ASMET. Proceedings of the 6th International Tooling Conference. Karlstad, Suécia, 2002. p. 633-641.

58 MEURLING, F. et al. Influence of carbide and inclusion contents on the fatigue properties of high speed steels and tool steels. Interna, v. 23, p. 215-224, 2001.

59 FERREIRA, G. E. G. Avaliação da resistência à fadiga térmica do aço AISI H13 nitretado pelos processos gasoso e por plasma. Dissertação (Mestrado) - Universidade Federal de Santa Catarina, Florianópolis, nov. 2001.

60 PERSSON, A.; HOGMARK, S.; BERGSTROM, J. Simulation and evaluation of thermal fatigue cracking of hot work tool steels. International Journal of Fatigue, v. 26, p. 1095-1107, 2004.

61 SJOSTROM, J.; BERGSTROM, J. Thermal fatigue testing of chromium martensitic hot-work tool steel after different austenitizing treatments. Journal of Materials Processing Technology, v. 153-154, p. 1089-1096, 2004.

62 PERSSON, A.; HOGMARK, S.; BERGSTROM, J. Thermal fatigue cracking of surface engineered hot work tool steels. Surface \& Coatings Technology, v. 191, p. 216-227, 2005.

63 CALISKANOGLU, D. et al. Thermal fatigue and softening behaviour of hot work tool steels. In: ASMET. Proceedings of the 6th International Tooling Conference. Karsltad, Suécia, 2002. p. 707-719.

64 NORSTRÖM, L. A.; SVENSSON, M.; ÖHRBERG, N. Thermal-fatigue behaviour of hot-work tool steels. Metals Technology, n. 8, p. 376-381, out. 1981.

65 FROEHLICH, A. R. Tratamento superficial DUPLEX com TiN e CrN de aços ferrameta da classe AISI H13 para matrizes de injeção de ligas de alumínio. Tese (Doutorado) - Universidade Federal do Rio Grande do Sul, Porto Alegre, 2003.

66 OTT, S.; DIEHL, M. D. Fadiga térmica em ferro fundido vermicular. In: ABM. Anais do 53ํㅡㄹ Congresso Anual da ABM. São Paulo, 1997. p. 359-376.

67 MANSON, S. S.; HALFORD, G. R.; HIRSCHBERG, M. H. Creepfatigue analysis by strain-range partitioning. In: AMERICAN SOCIETY OF MECHANICAL ENGINEERS. Proceedings of the First National Pressure Vessel and Piping Conference. Ohio, 1971. p. 30.

68 ZINN, S.; SEMIATIN, S. L. Coil design and fabrication: basic design and modifications. Heat treating, p. 32-41, june 1988.

69 BATELO, E. A. P. Análise dinâmica avançada de estruturas de aço sob cargas extremas. 70 p. Dissertação (Mestrado) - Universidade Federal de Ouro Preto, Ouro Preto, MG, 2014. 
70 BRAGA, A. P. V.; BOCCALINI JR., M.; LEMOS, B. de C. Ensaios de fadiga térmica em aços para moldes de injeção de Alumínio. São Paulo, 2017. Acesso restrito.

71 SILVA, W. S. da. Estudo da tenacidade à fratura do aço rápido M2 fundido, modificado e tratado termicamente. 152 p. Dissertação (Mestrado) Escola Politécnica da USP, São Paulo, 2001.

72 EMISSIVIDADE. http://www.vortex.com.br/raytek/emissividade. html. Acessado em: 26/05/2017.

73 GELL, M.; LEVERANT, G. R. Mechanisms of high-temperature fatigue. In: AMERICAN SOCIETY FOR TESTING AND MATERIALS. Fatigue at elevated temperatures ASTM STP 520. [S.I.], 1973. p. 37-67.

74 CAMPBELL, J. Entrainment defects. Materials Science and Technology, n. 2, p. 127-145, 2006.

75 MONTEIRO, M. de J. Estudo da oxidação de aços rápidos em atmosfera de ar seco e úmido e em condição de ciclagem térmica. Tese (Doutorado) PUC, Departamento de Ciência dos Materiais e Metalurgia, Rio de Janeiro, 2002.

76 BARRETT, C. A.; LOWELL, C. E. Comparison of isothermal and cyclic oxidation behavior of twenty-five commercial sheet alloys at $1150^{\circ} \mathrm{C}$. Oxidation of Metals, v. 9, n. 4, p. 307-355, 1975.

77 MEVREL, R. Cyclic oxidation of high-temperature alloys. Materials Science and Technology, v. 3, p. 531-535, 1987.

78 BONFRISCO, L. P.; FRARY, M. Effects of crystallographic orientation on the early stages of oxidation in nickel and chromium. Journal of Materials Science, v. 45, p. 1663-1671, 2010.

$79 \mathrm{YU}, \mathrm{X}$. et al. Dependence of texture development on the grain size of tertiary oxide scales formed on a microalloyed steel. Surface and Coatings Technology, v. 272, p. 39-49, 2015.

80 NEU, R. W.; SEHITOGLU, H. Thermomechanical fatigue, oxidation and creep: Part i. damage mechanisms. Metallurgical Transactions A, v. 20A, p. 1755-1767, 1989.

81 NEU, R. W.; SEHITOGLU, H. Thermomechanical fatigue, oxidation and creep: Part ii. life prediction. Metallurgical Transactions A, v. 20A, p. 1769-1783, 1989.

82 AUINGER, M. et al. Grain boundary oxidation in iron-based alloys investigated by 180 enriched water vapour. Corrosion Science, v. 96, p. 133-143, 2015. 
Apêndice A - Imagens de tomografia 



\section{A.1 Corpo de prova REF2 - Vista rotacional: 0 - 180}

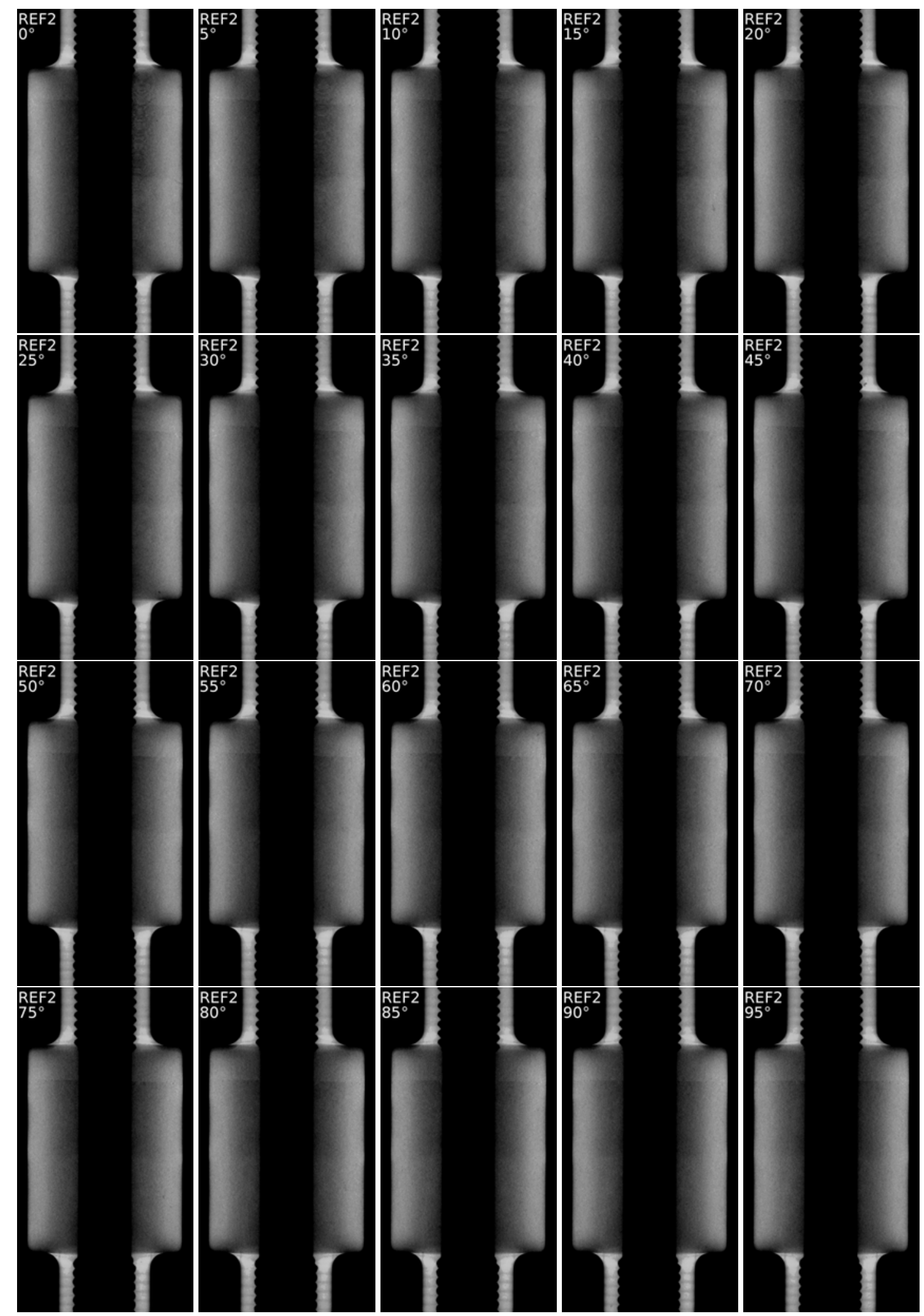




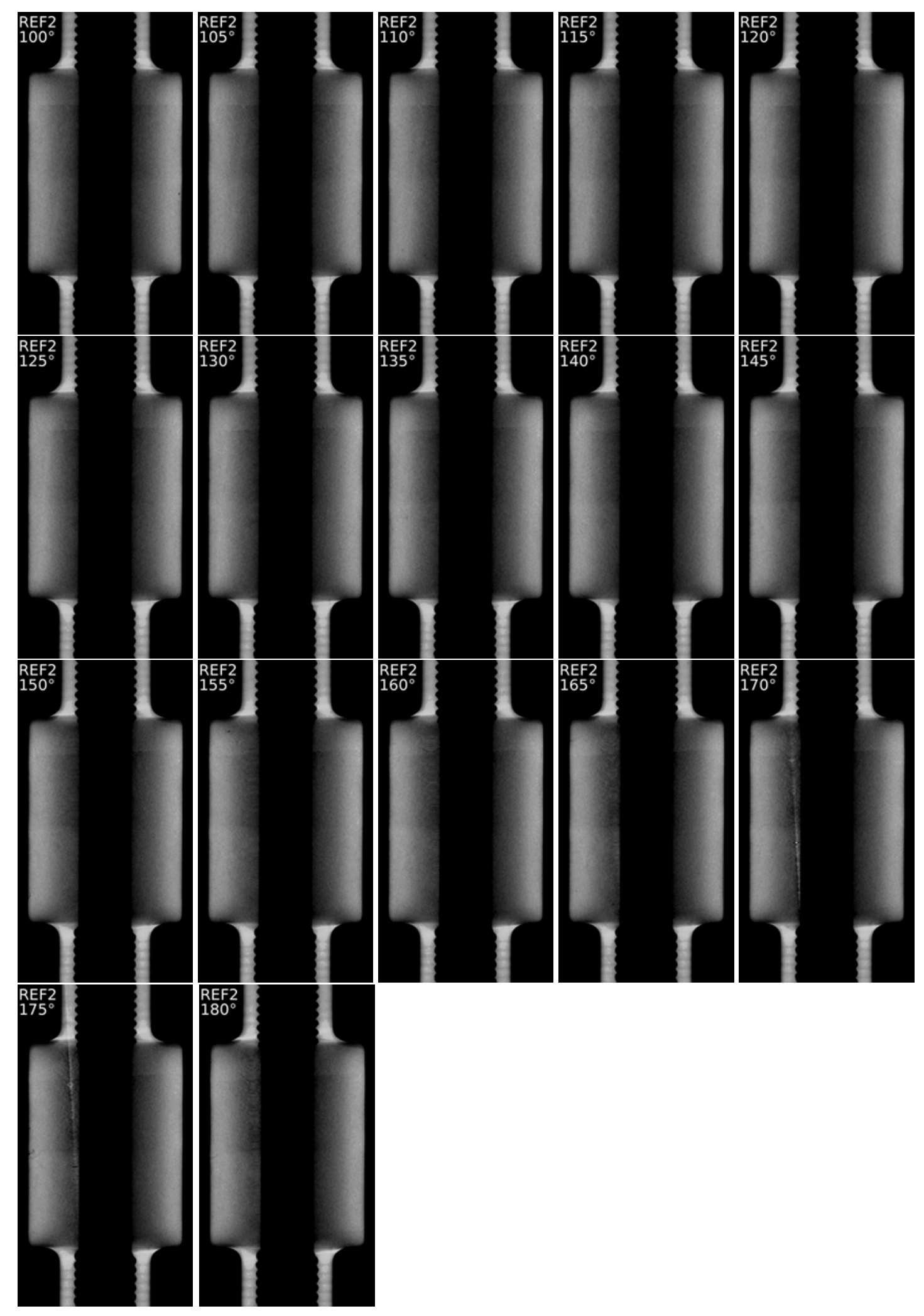




\section{A.2 Corpo de prova REF2 - Vista direita: 1 - $30 \mathrm{~mm}$}

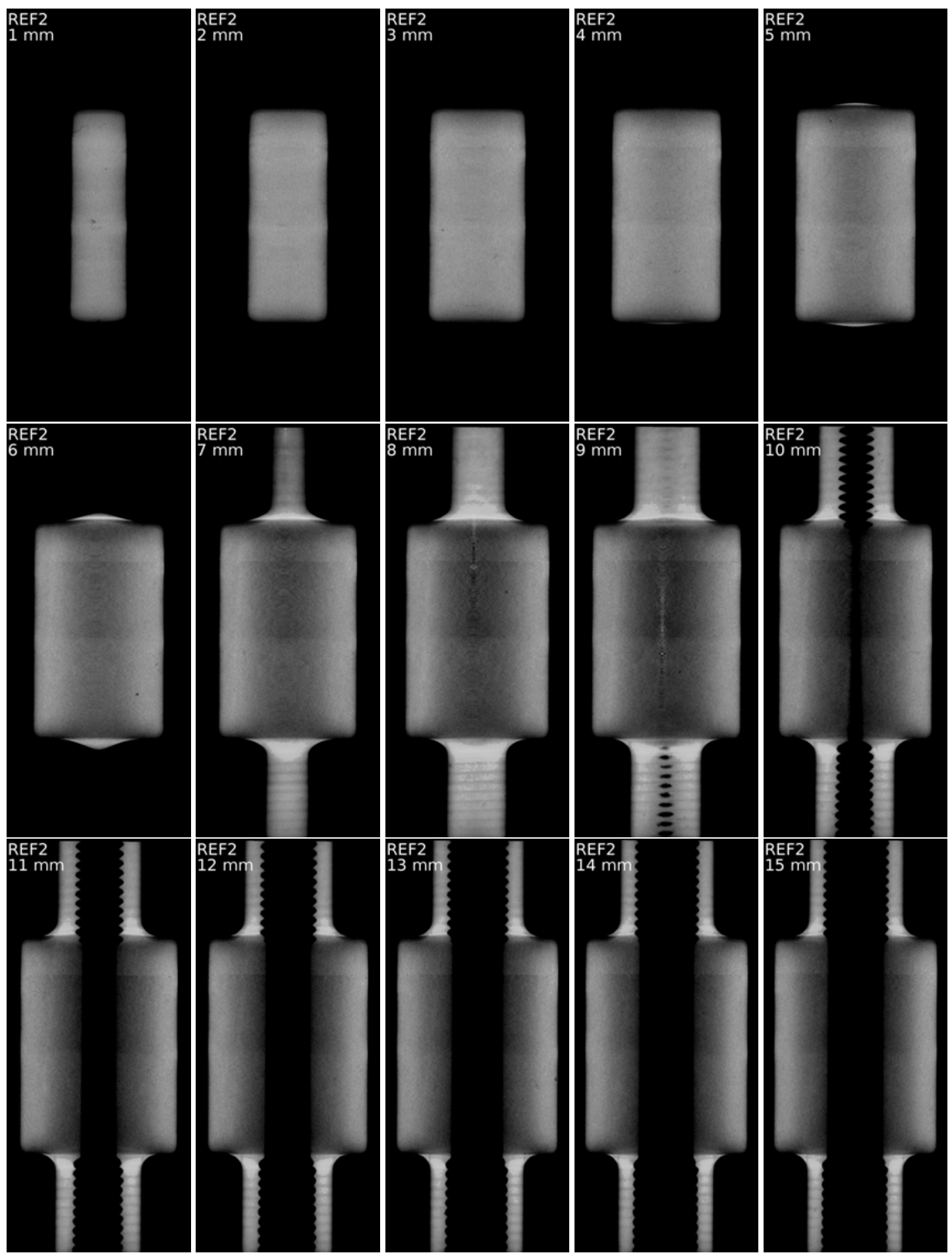




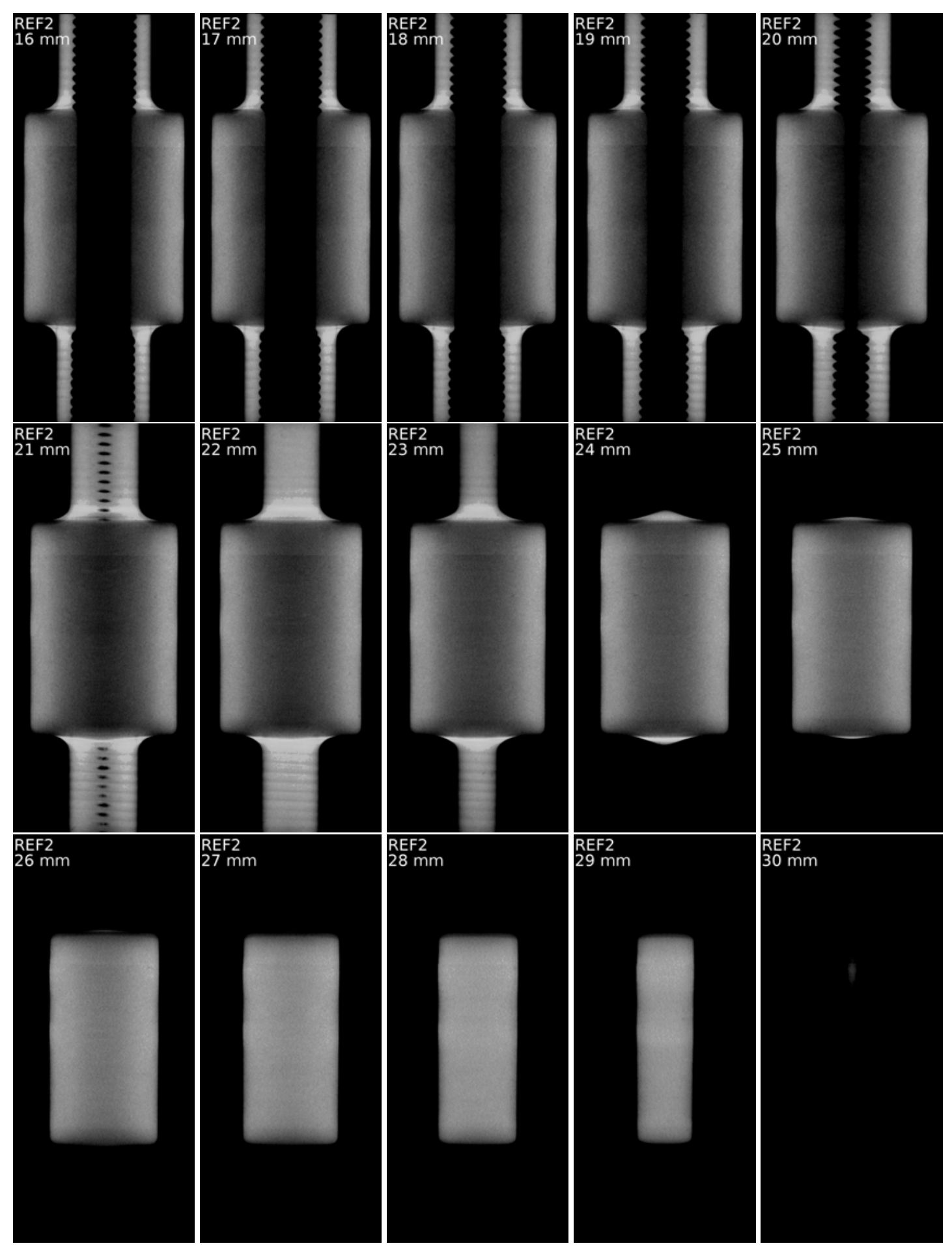




\section{A.3 Corpo de prova REF2 - Vista de topo: 1 - $77 \mathrm{~mm}$}

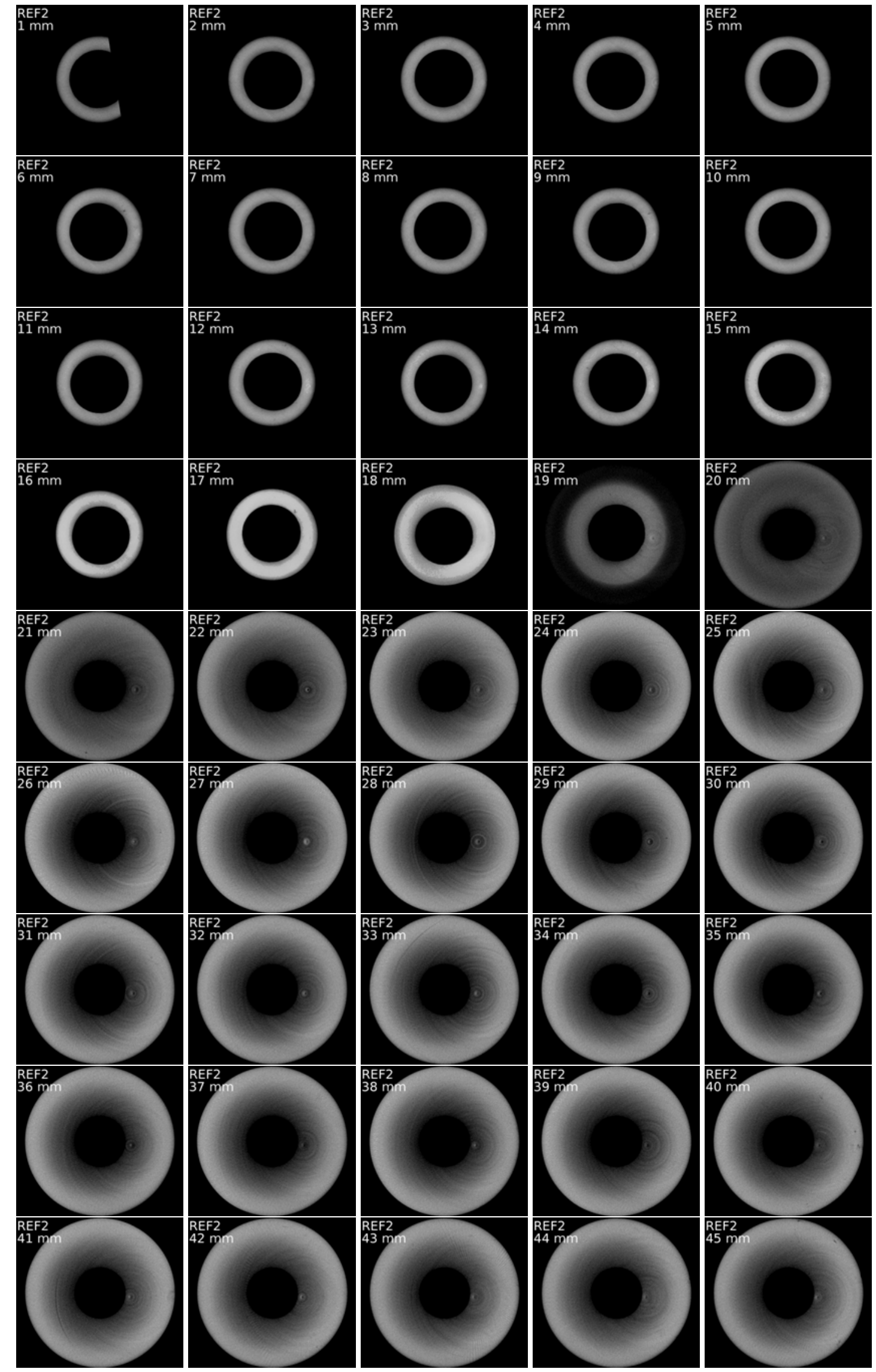




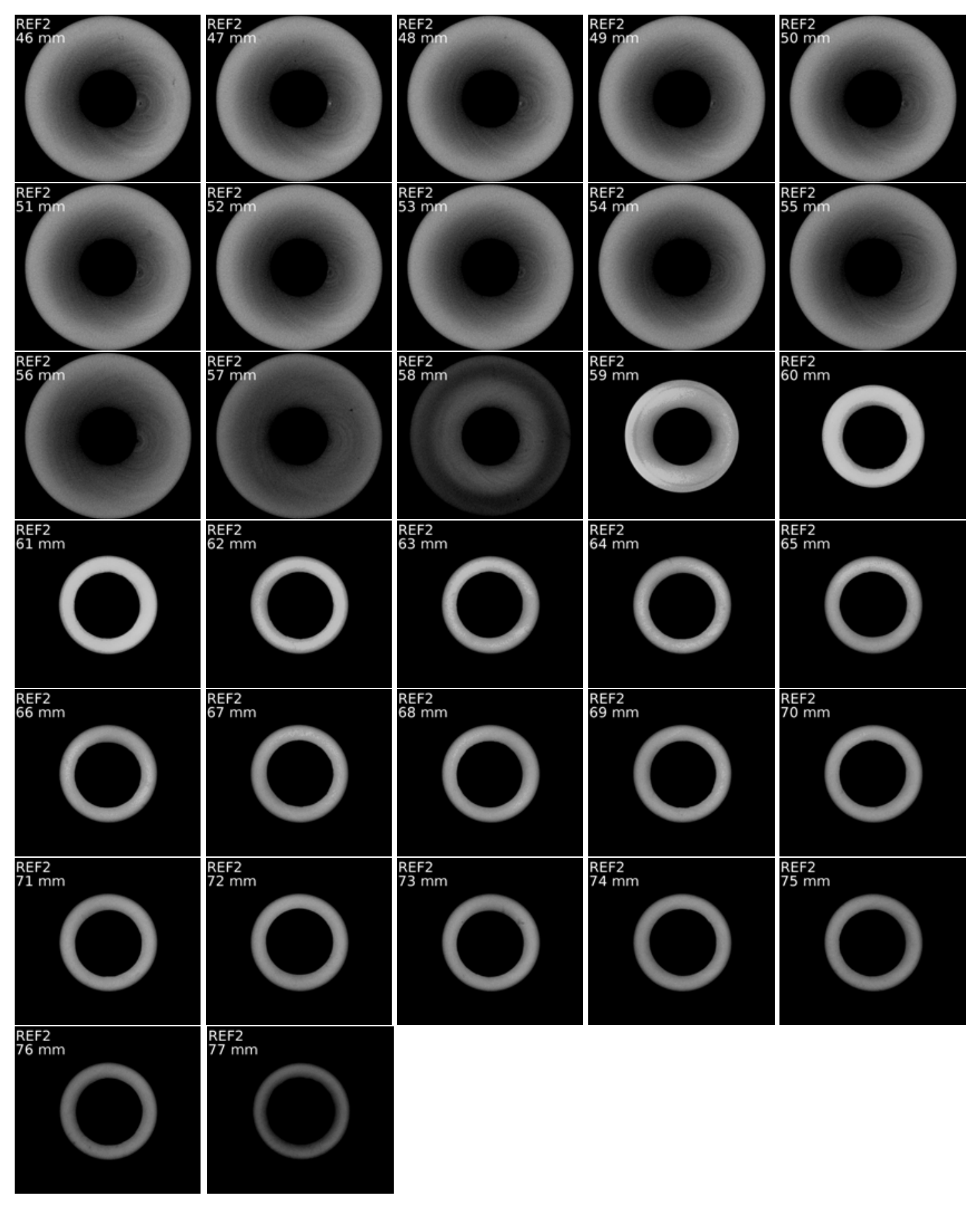




\section{A.4 Corpo de prova HOT2 - Vista de topo: 1 - $77 \mathrm{~mm}$}

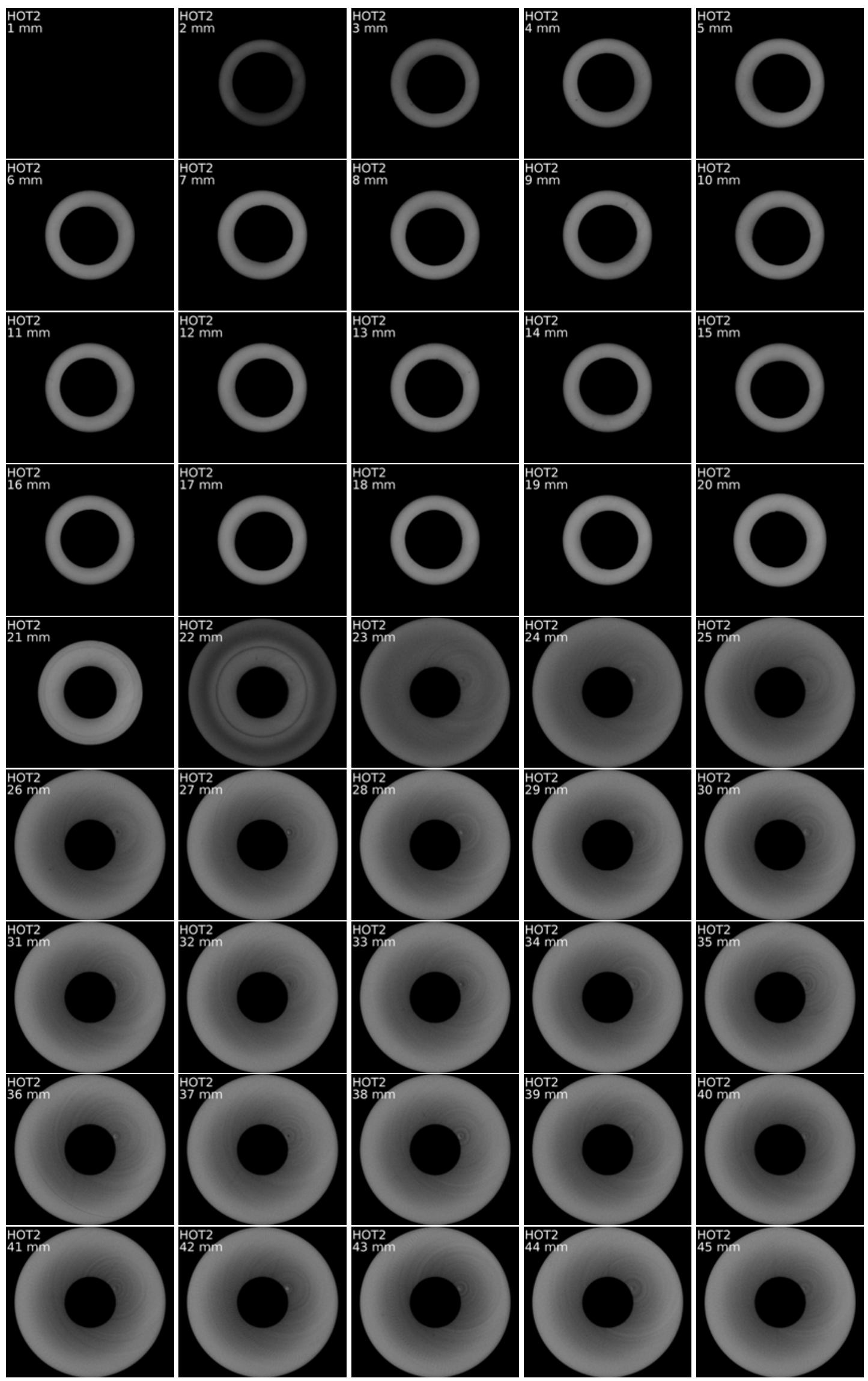




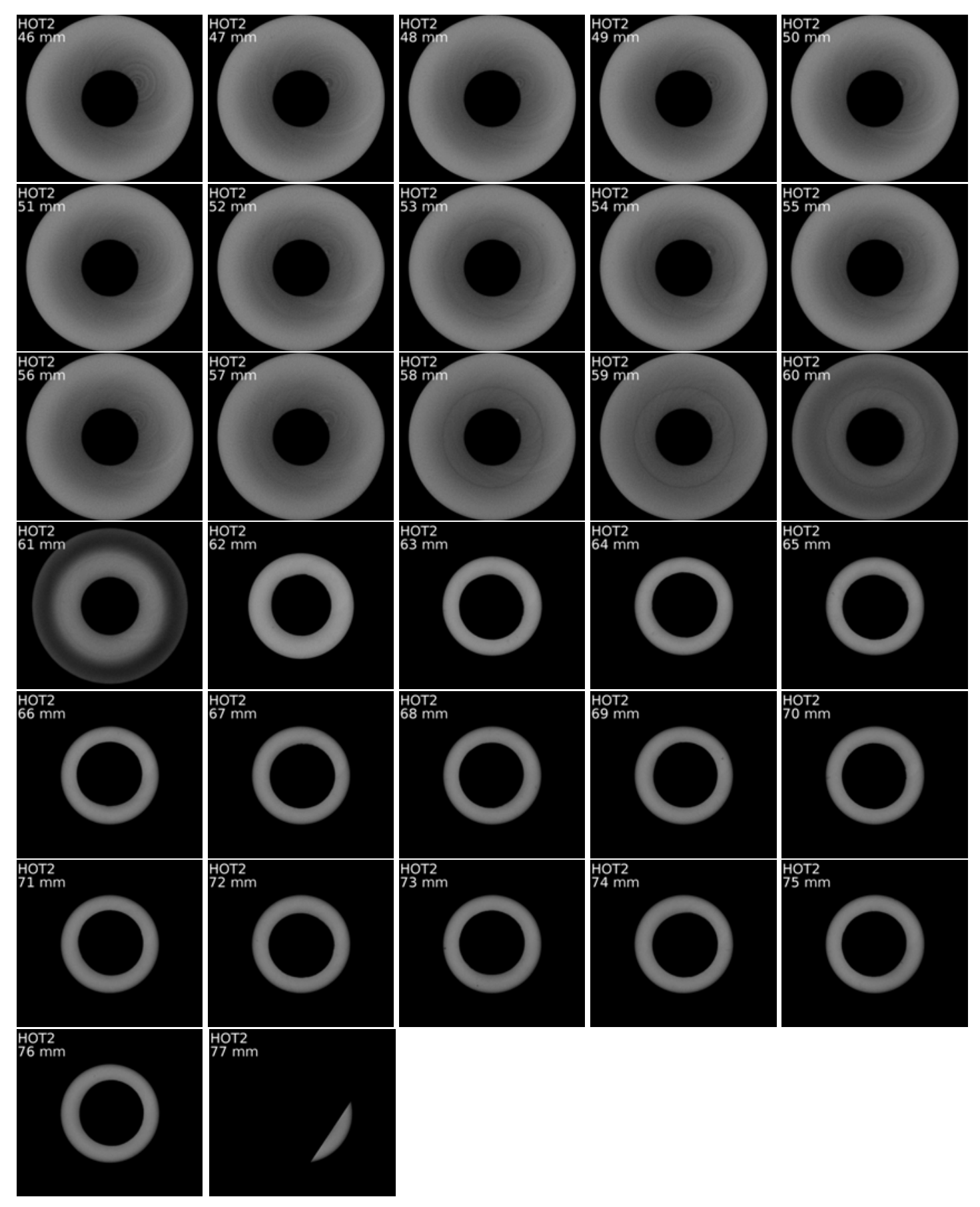




\section{A.5 Corpo de prova HOT2 - Vista rotacional: 0 - 180 ${ }^{\circ}$}

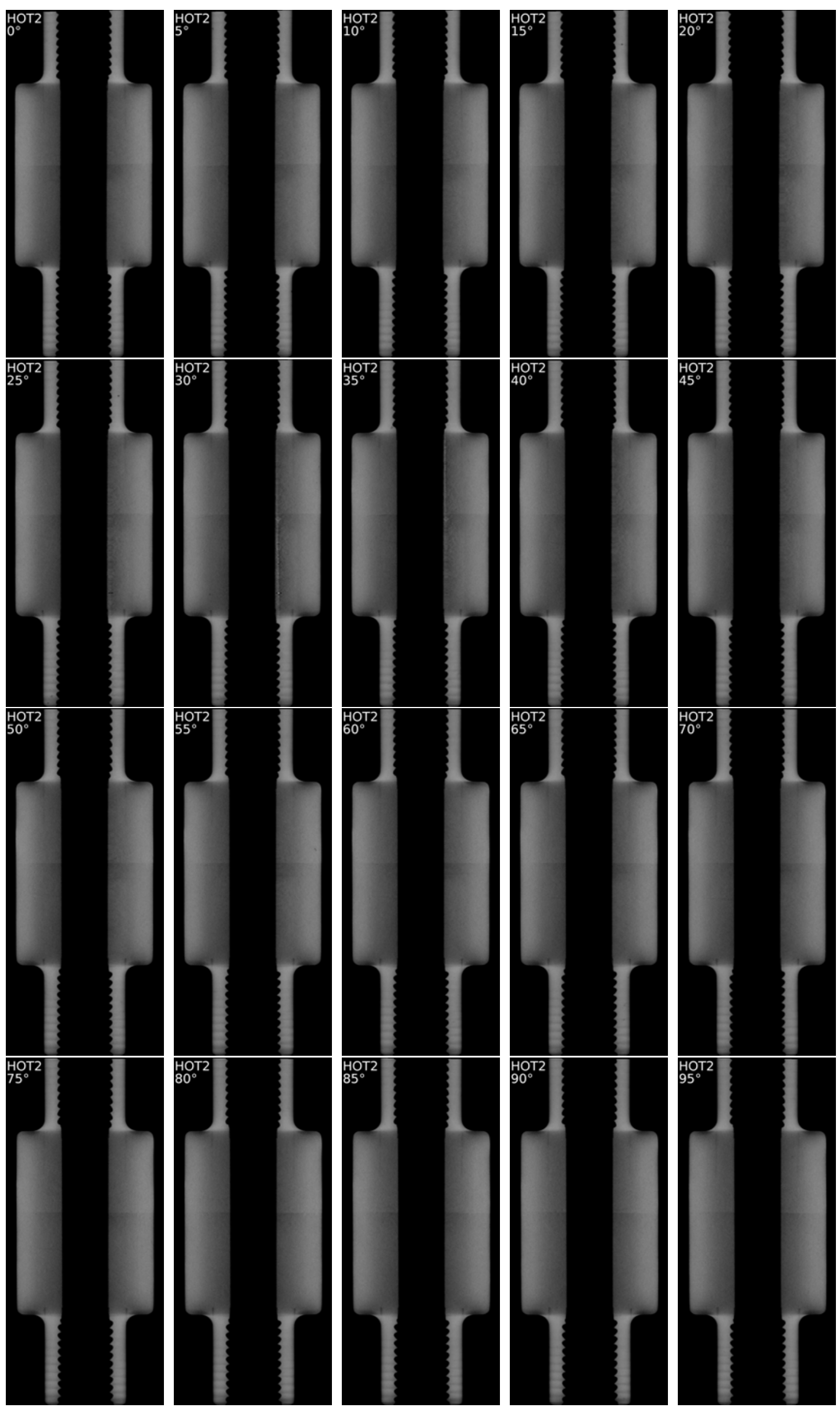




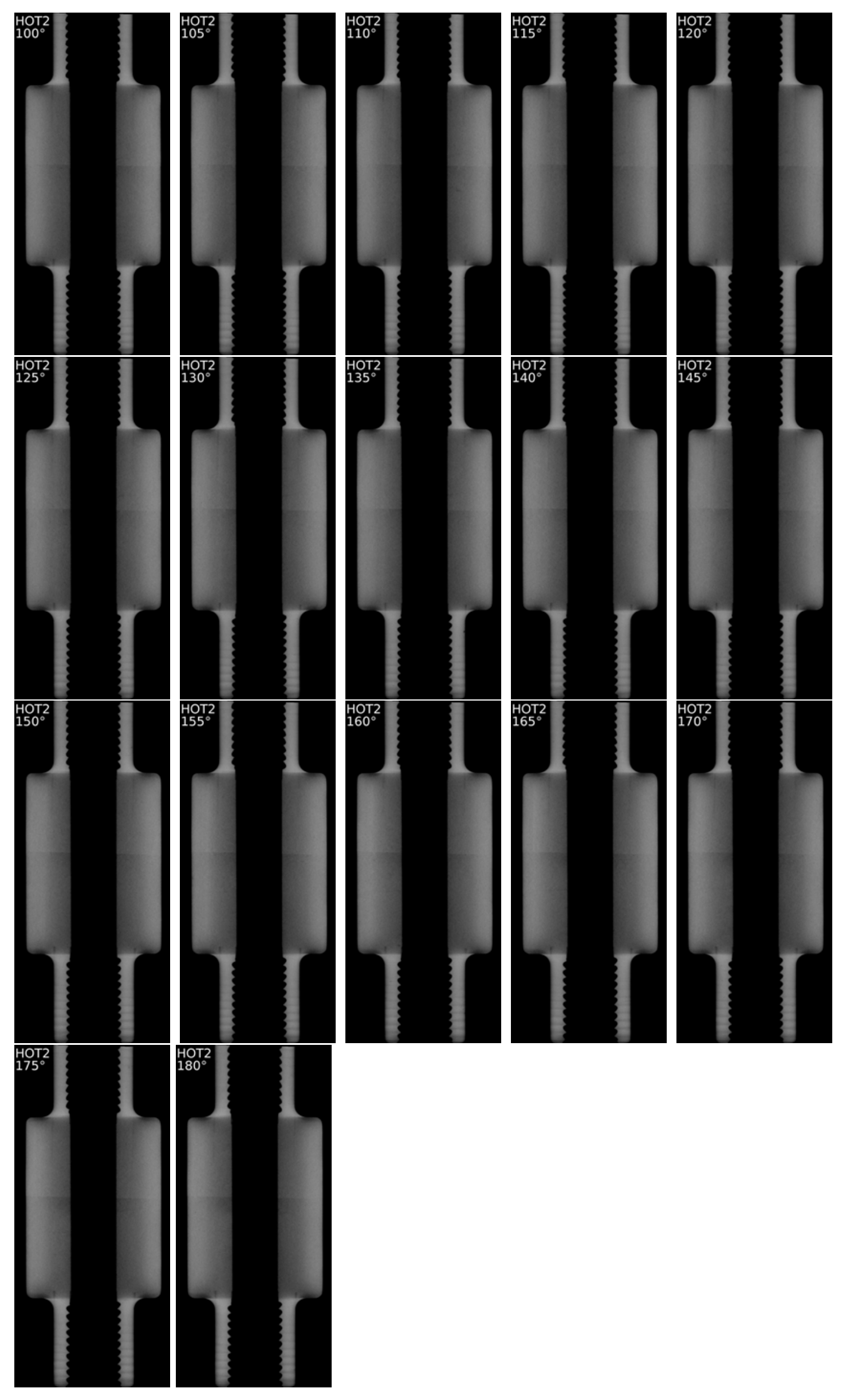




\section{A.6 Corpo de prova LOW2 - Vista rotacional: 0 - 180}

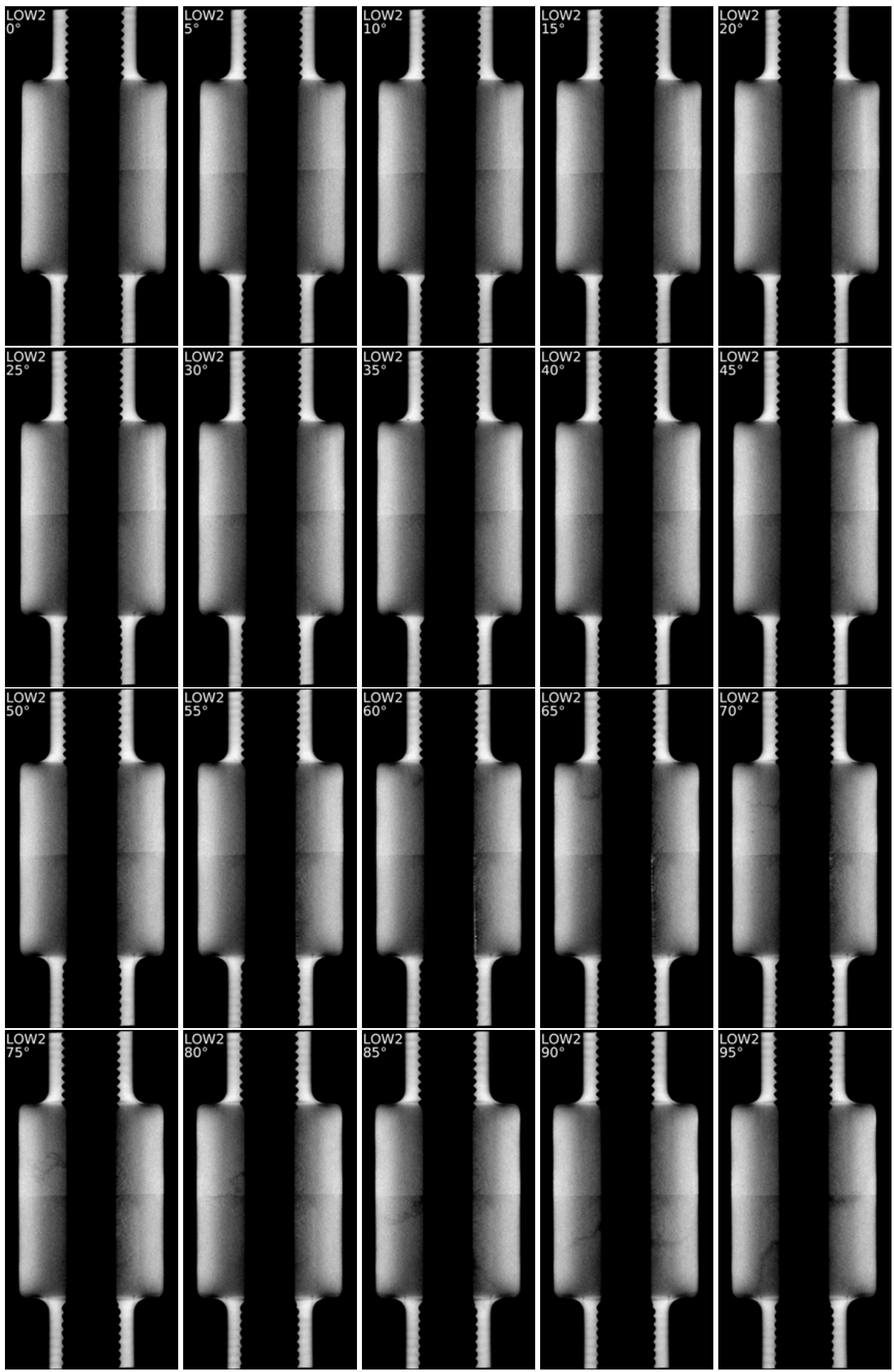




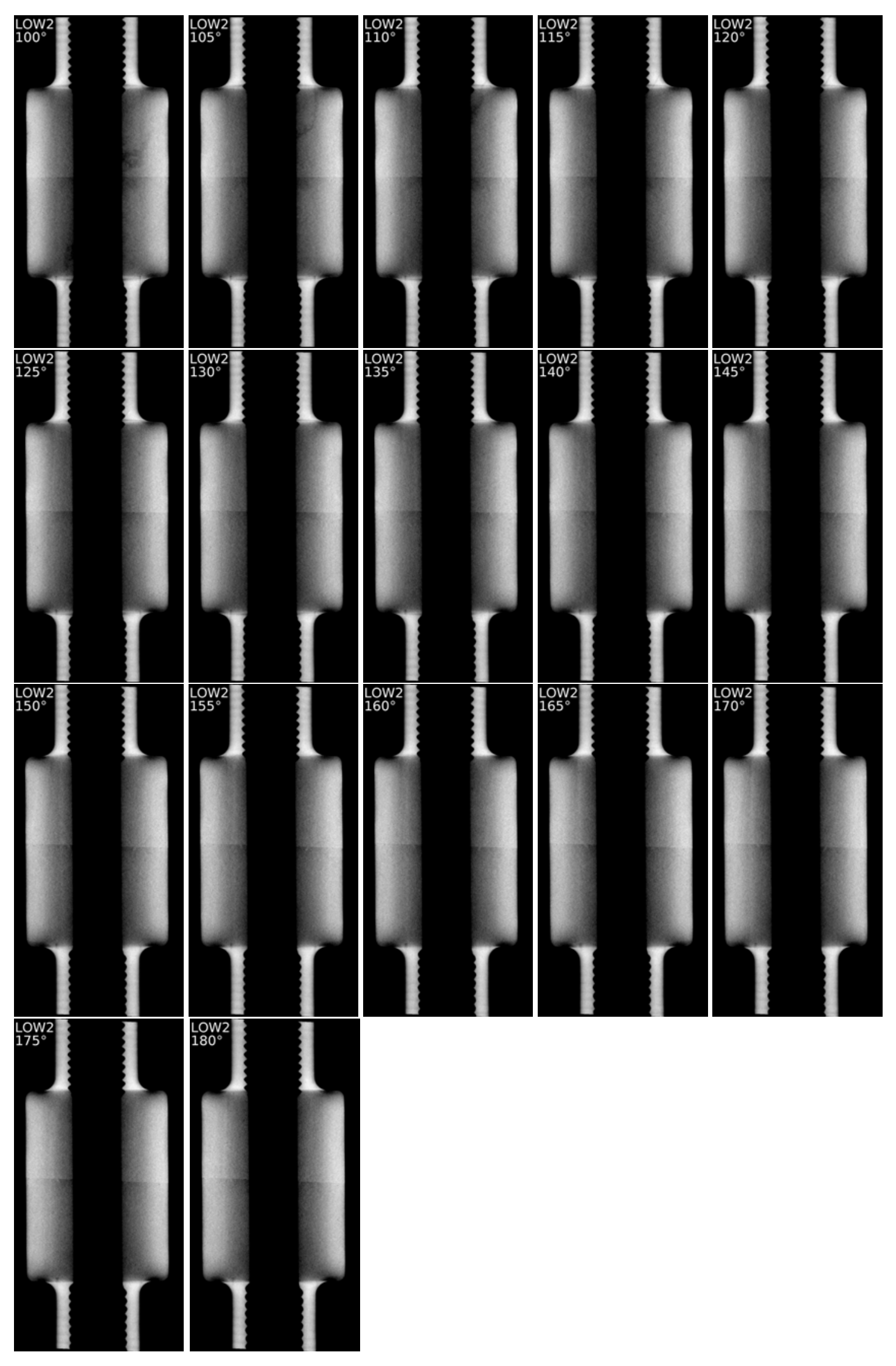




\section{A.7 Corpo de prova LOW2 - Vista direita: 1 - $30 \mathrm{~mm}$}

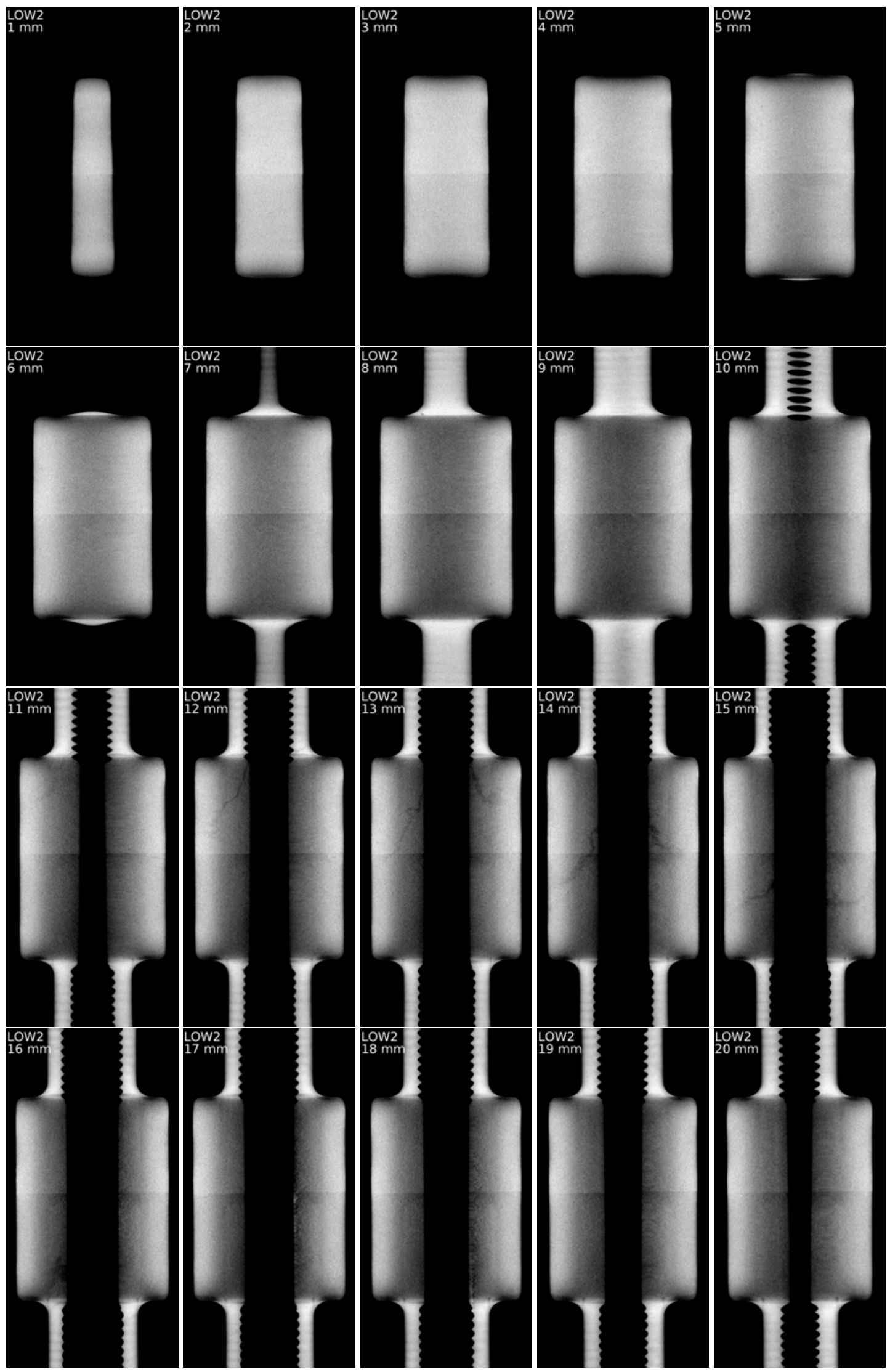




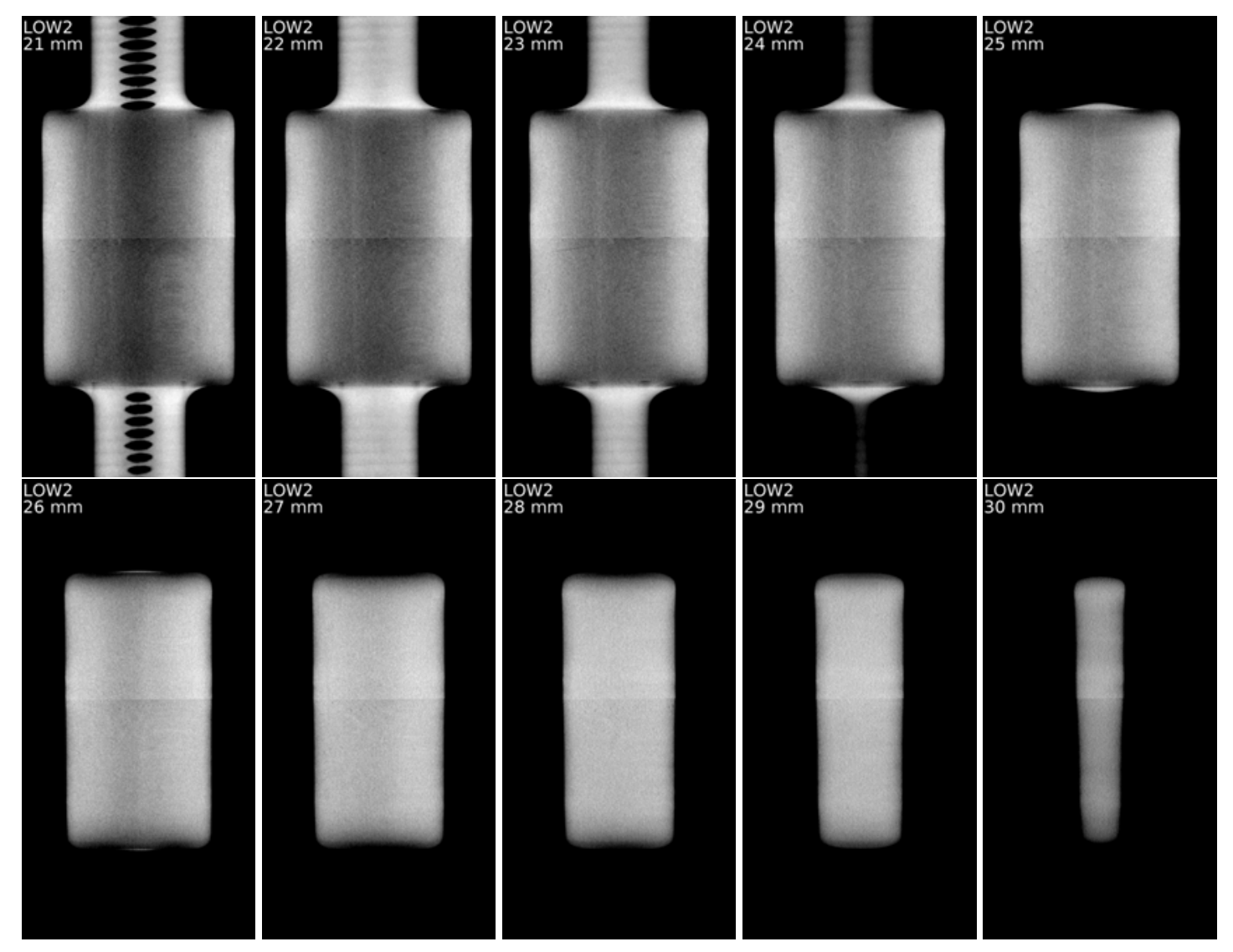


A.8 Corpo de prova LOW2 - Vista de topo: 1 - $70 \mathrm{~mm}$

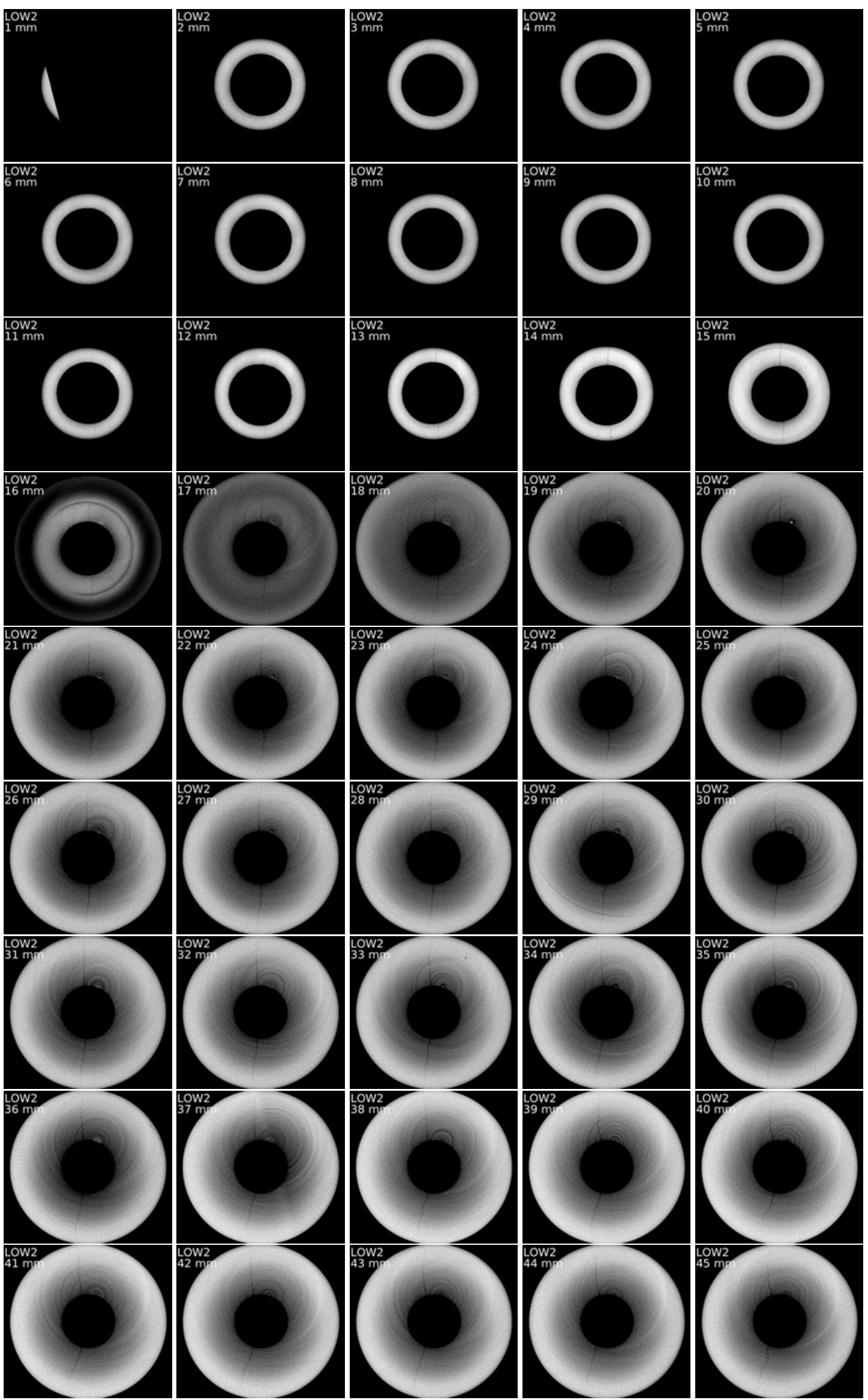




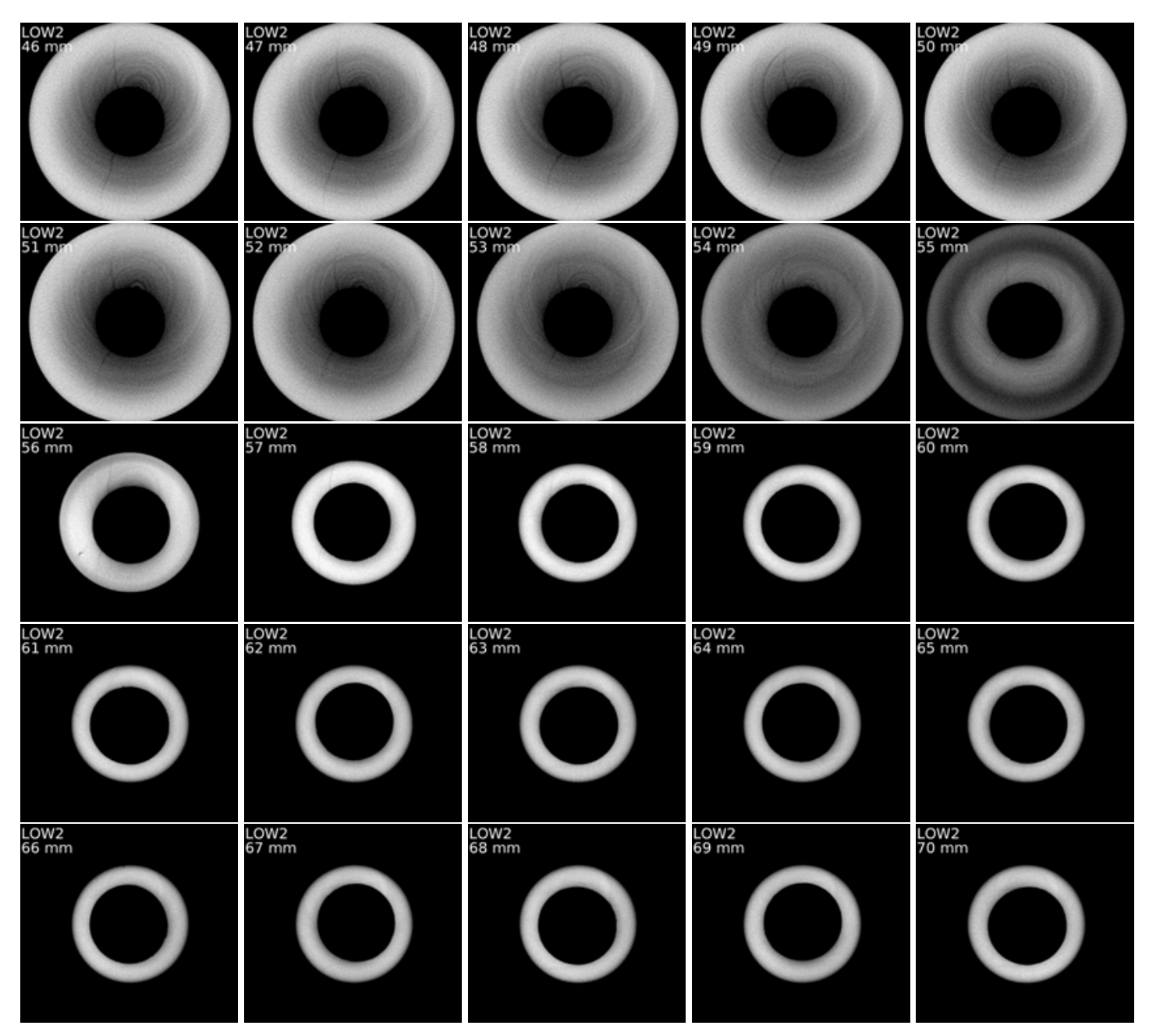




\section{A.9 Corpo de prova REV1 - Vista rotacional: 0 - $180^{\circ}$}

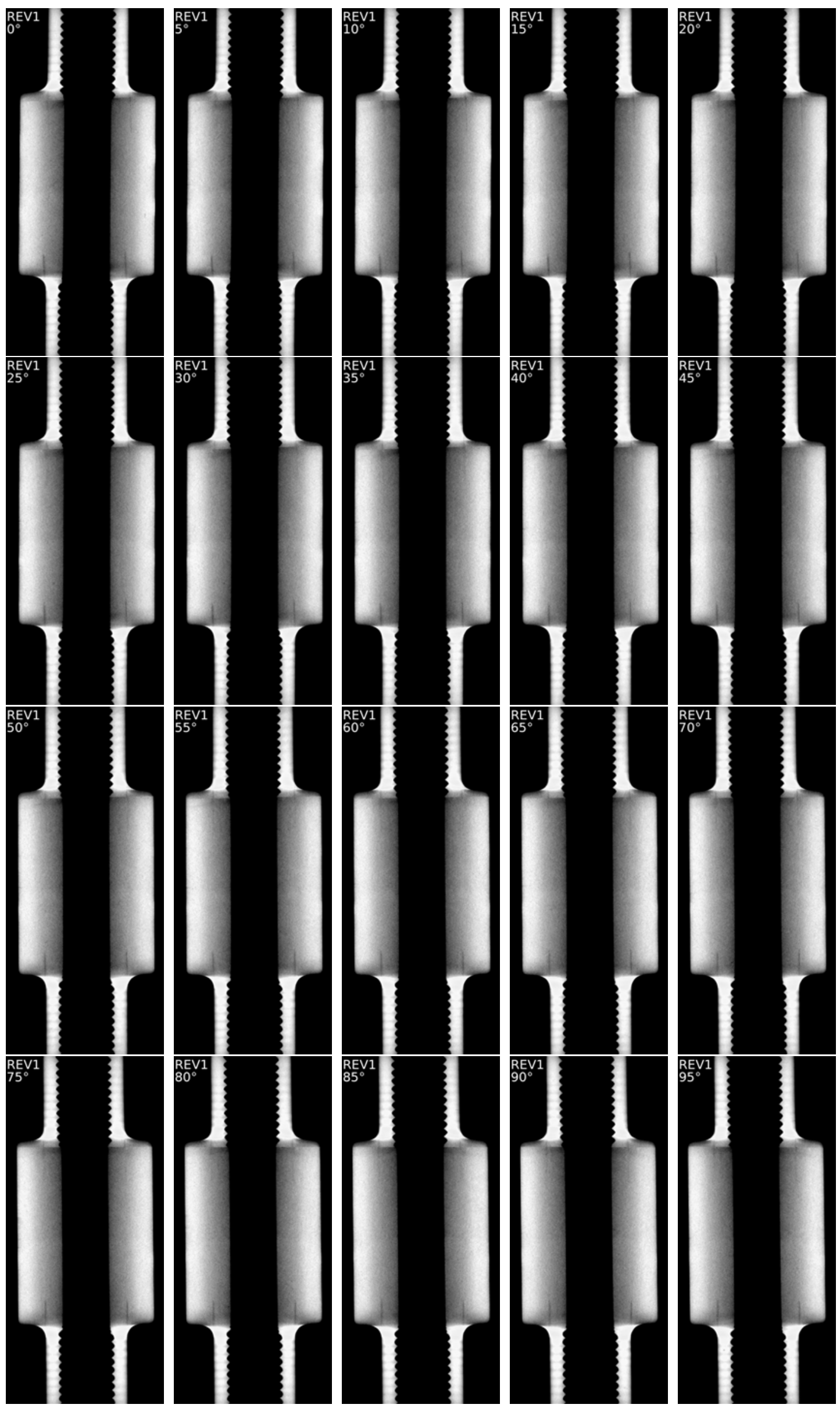




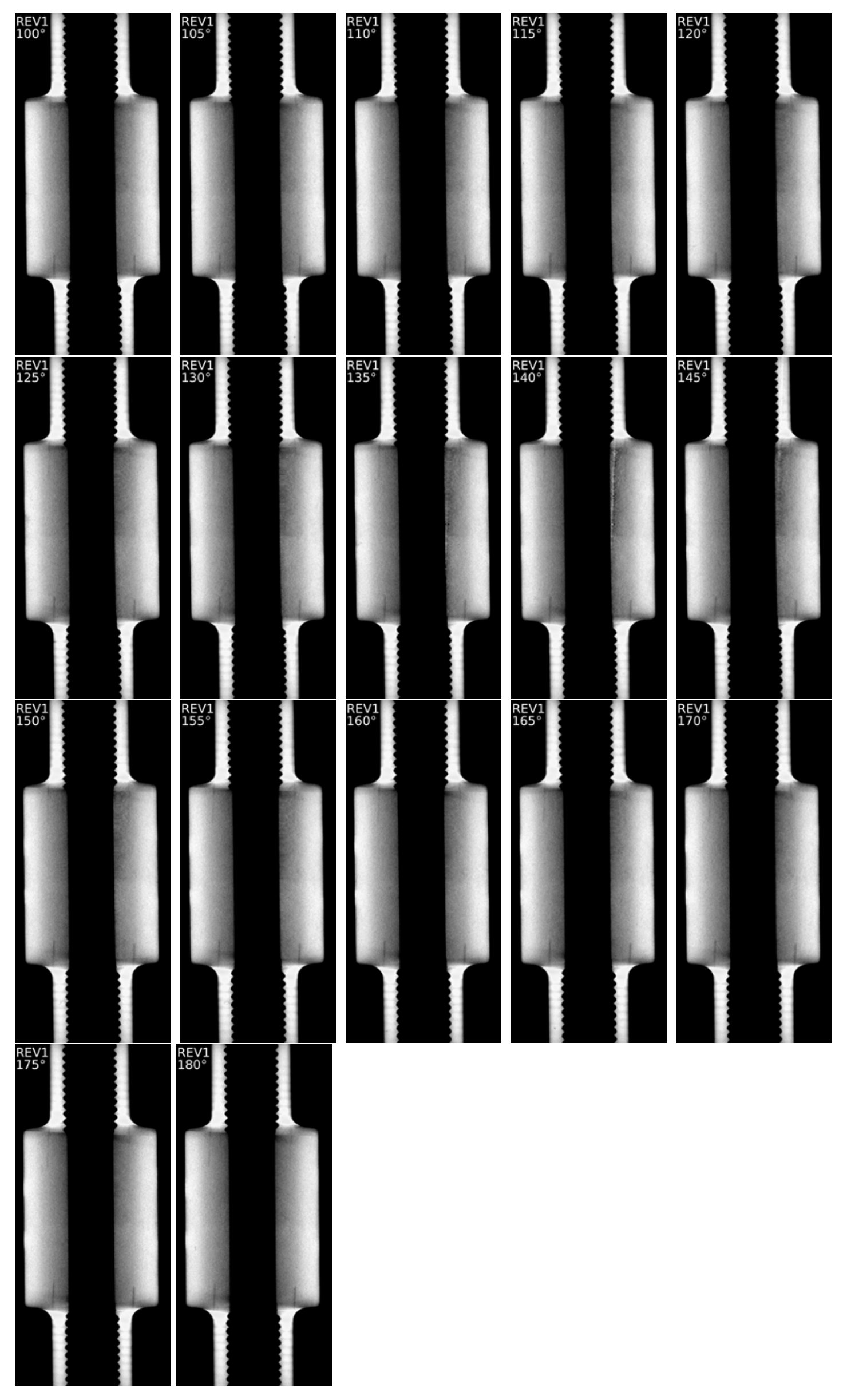




\section{A.10 Corpo de prova ARG1 - Vista de topo: 1 - $78 \mathrm{~mm}$}

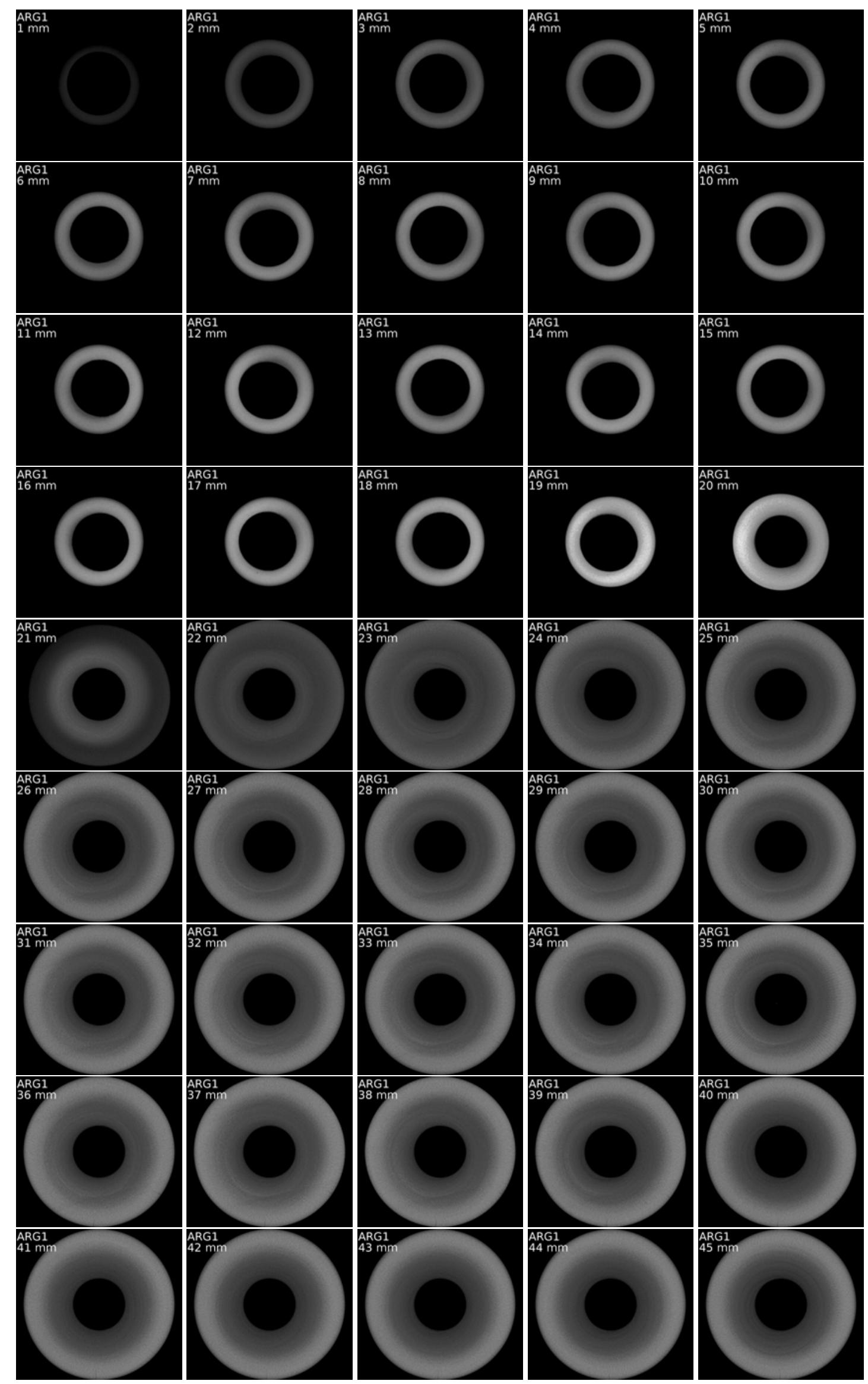




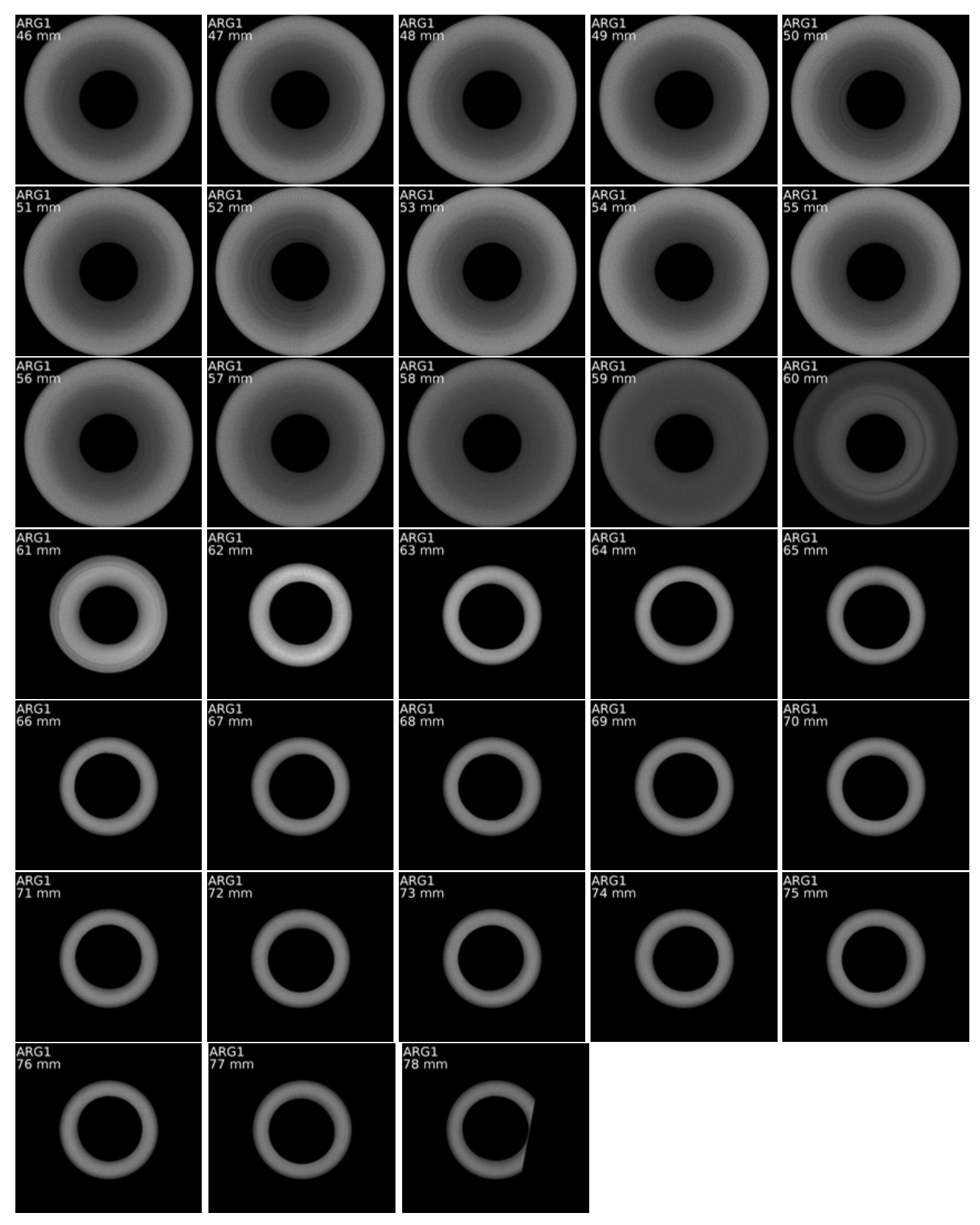




\section{A.11 Corpo de prova ARG1 - Vista rotacional: 0 - 180}
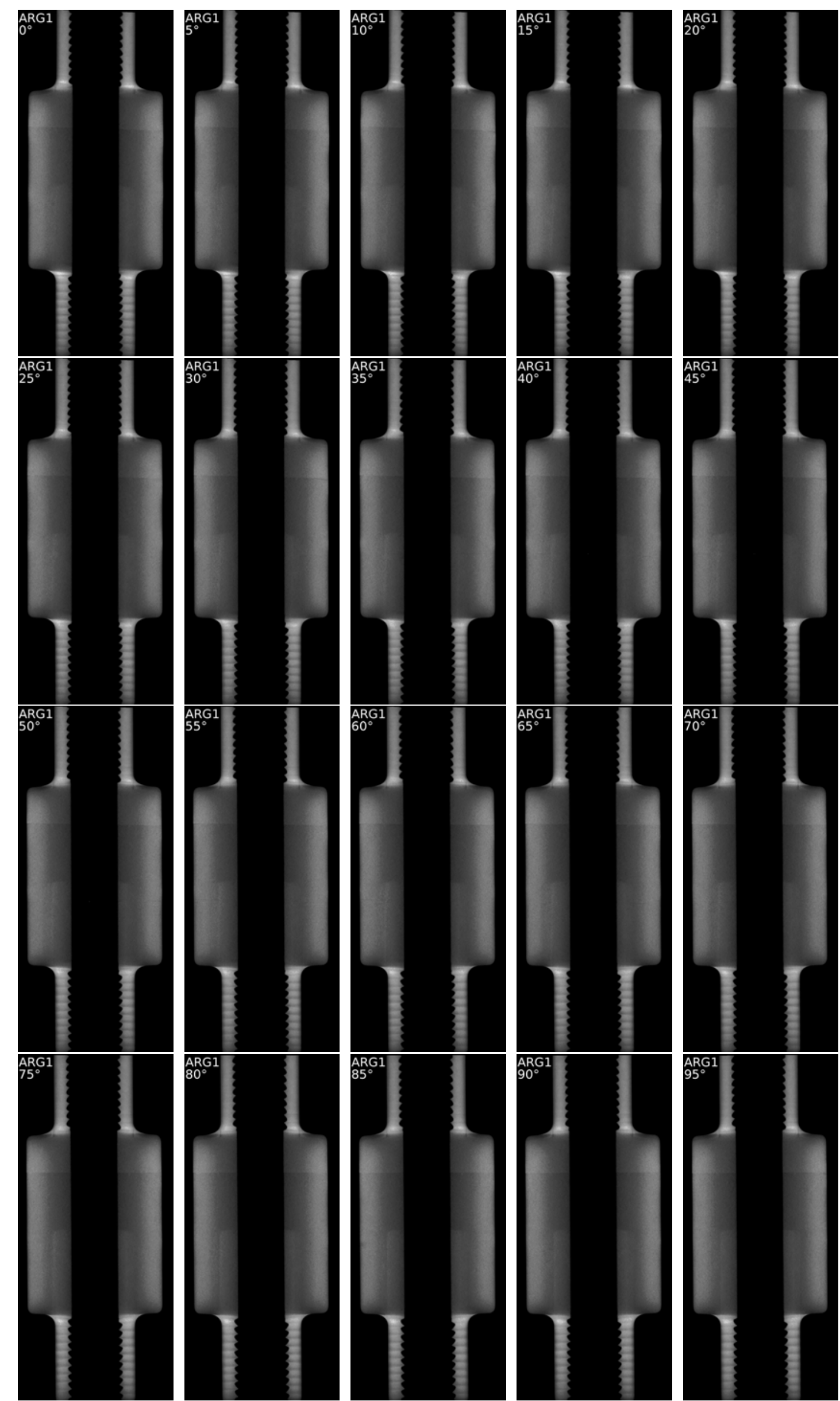


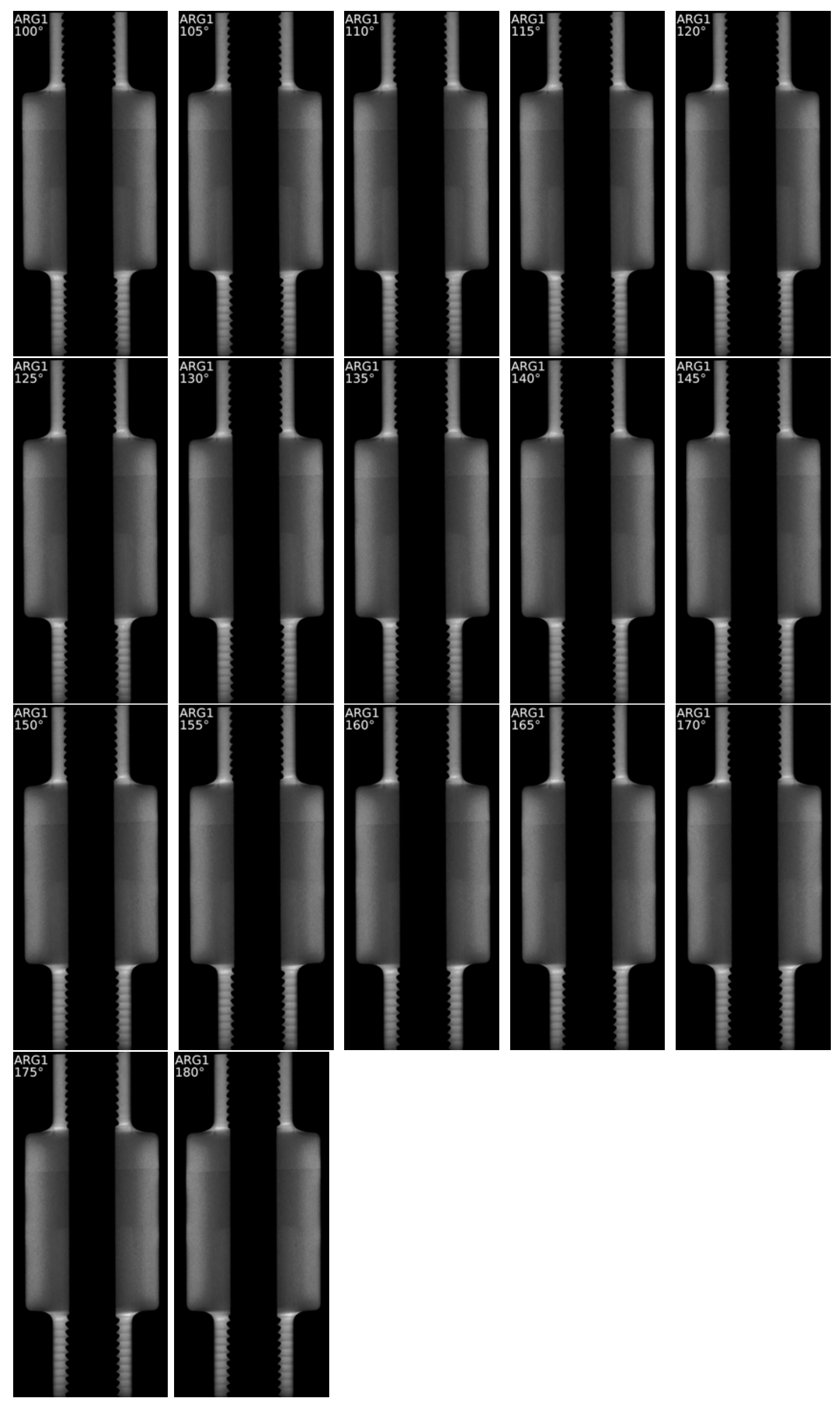

